Diss. ETH Nr. 15169

\title{
RESOURCE POTENTIALS AND LIMITATIONS OF A NICARAGUAN AGRICULTURAL REGION
}

\author{
Abhandlung zur Erlangung des Titels \\ DOKTORIN DER WISSENSCHAFTEN \\ der \\ EIDGENÖSSISCHEN TECHNISCHEN HOCHSCHULE ZÜRICH
}

\author{
vorgelegt von \\ Franziska Pfister \\ Dipl. Natw. ETH \\ geboren am 19. August 1973 \\ von Uetendorf BE
}

Angenommen auf Antrag von

Prof. Dr. Peter Baccini, Referent

Prof. Dr. Hans Hurni, Korreferent

Dr. Hans-Peter Bader, Korreferent

Zürich 2003 


\section{Distribution}

EAWAG

Library

Überlandstrasse 133

CH-8600 Dübendorf

Tel. ++41-1-823 $5531 / 32$

Fax: ++41-1-823 5028

E-mail: bibliothek@eawag.ch http://www.eawag.ch

\section{Further information}

Franziska Pfister

E-mail: francisca_p@bluemail.ch 


\title{
A MIS AMIGOS EN NICARAGUA
}

\begin{abstract}
Elenita, Chilito, Javier y Hermi, Emmanuel, Alvaro, Rosaura, María José, Carlos, César, Emma y familia, Juanita, Mama Nen, Nelly y familia, Amy y familia, Tincho y familia, Jairo, Milagros y Toño Amigas del CDI Masatepe Magda, Martha e Iliana; amigos y amigas de COODEPAGRO, Manuel, Patricia, Don Silvio, productores y en especial Marlin y Don Manuel Prado; amigas y amigos de la UNA, especialmente Aurorita, Marbel Aguilar, Roberto Blandino, Ignacio Rodríguez Ibarra, Guillermo Reyes Castro, Carlos Ruíz, Francisco Salmerón, Marina Ulmos Vado; de ODESAR, especialmente Ana María, Carla, Diego, Flor, Harold, Hilda, Polo, Jaime, Juanita, Doña Marcia, María Isabel, Miguel, Orlando, Téres, y muchos más; del CIAT: María Eugenia Baltodano, Axel Schmidt, Pedro Pablo Orozco, Trinidad Reyes, Yuritza, Jorge Alonso Beltrán; los del SDA Martín Amador, Martín Pineda, Salvador Calderón, Isaac Rivera; los del „barrio loco“Adam, Doña Balta, Blanca, Jacqueline, Juanita, Norlan, Lidia, Lola, Reyna, Reyna, Sulema, Wilbert, Aracely y Victor; los del pueblo Doña Adelina, Don Braulio y Andrea, Don Lino y familia, Omar y Juanita; Doña Bertha Jarquín; los de Susulí Doña Azucena, Claudia, Don Francisco Coronado, Brígido Castro, Don Ramón, Don Valerio Mercado, Marlene; muchas gracias a Ernesto, Digna, Jacqui, Roxana, y más de todo a mis amigos productores de Susulí Santos Aguilar, Anselmo Aráuz Godines, Balvino Aráuz Martínez, Gorgonio Aráuz Martinez, Juan Aráuz López, Justino Blandino, Ramón Blandón, Sebastián Blandón Ochoa, Alejandro Castro Zeledón, Eliodoro Castro Pastrán, Hermes Castro Zeledón, Marvin Castro Zeledón, Emilio Chavarría, Damaso Cruz, Gregorio Cruz Vargas, José Anito Cruz López, Seferino Cruz, Eulalio d'Escoto, Gregoria Díaz Salgado, Carlos Dormuz, Samuel Dormuz, Felix Escobar, Medardo Figueroa Pérez, Santos Figueroa Hernández, Victorino García Maldonado, Leonso Granado, Orlando Gurdián, Cándido Hernández Mercado, Esteban Hernández, Pedro Hernández, Vicenta Hernández Pérez, Juana Herrera Suazo, Francisco Huerta, Benigno Laguna, Pedro Celino López, Ernesto Martínez Garcia, Victorino Mercado, Juan Francisco Molinares, Elias López Muñoz, Eliodoro Ochoa, Sebastian Orellano, Encarnación Orozco, Rosa Orozco Mendez, María Leonor Ortuño, Francisco y Ramón Pastrán, Julio Pastrán, Cecilio Pérez, Apolinas Porras, Audilio Rivera, José Robleto, Segundo Robleto, Roman Rodríugez Muñoz, Martha Romero Tellez, Juan José Rosales, Eliazar Sequeira Hernández, Gustavo Sequeira Hernández, Mercedes Tercero, Alvaro Torrez, Hipólito Treminio Morán, Domingo Trujillo, Andrés Vanega, Tomás Zamora Aráuz y Agustín Zeledón
\end{abstract}

\section{A MIS PAPÁS}





\section{Dank}

Meine Eltern haben mir Tür und Tor zu Aus- und Weiterbildungen geöffnet und mich in jeder Hinsicht unterstützt. Somit ermöglichten sie mir den Zugang zu der Welt des Wissens, welche mich unendlich bereichert hat. Meine Familie war in guten und stürmischen Zeiten der Hafen, wo mein Schiff vor Anker ging. Vielen Dank allen drei!

Prof. Peter Baccini möchte ich von ganzem Herzen für die Möglichkeit danken, diese Forschungsarbeit über ein Thema durchzuführen, welches mich nicht nur interessiert, sondern auch bewegt. Für Fragen und Diskussionen stand die Tür des Chefs immer offen, was ich sehr geschätzt habe.

Meinen beiden Korreferenten Prof. Hans Hurni und Dr. Hans-Peter Bader möchte ich für die angenehme Zusammenarbeit danken.

Ohne die Kollegen und Kolleginnen an der S+E wäre diese Zeit nicht so interessant, anregend und auch nicht so lustig gewesen. Besonders dankbar bin ich für die Diskussionen und Gespräche mit Florian Hug und Esther Leemann. Speziell möchte ich auch Hans-Peter Bader und Ruth Scheidegger für ihren grossen Einsatz bei der dynamischen Modellierung danken.

Auch in Nicaragua haben mich viele Menschen bei meiner Arbeit begleitet. Sie haben mir ermöglicht, mich in diesem Land immer wieder zu Hause zu fühlen. Dafür und auch für die Offenheit und Herzlichkeit, mit welcher sie mir begegnet sind, bin ich ihnen zutiefst dankbar.

Vielen Dank auch meinen Freundinnen und Freunden in der Schweiz. Sie haben mich immer auch neben der Diss ,auf Trab“ gehalten und mich auch nach längeren Abwesenheiten wieder herzlich aufgenommen.

Auch an der EAWAG haben viele Leute dafür gesorgt, dass ich immer wieder gerne zur Arbeit ging. Besonders in Erinnerung werden mir dabei Monika Zemp, Liselotte Schwarz und Maria Huber bleiben.

Gabo war mir während dieser Jahre mehr als ein Partner und Freund. Für unsere zahlreichen Forschungsdiskussionen, für das sorgfältige Korrekturlesen und insbesondere für all die schönen gemeinsam verbrachten Stunden möchte ich ihm herzlich danken. 



\section{Index}

ABSTRACT V V

ZUSAMMENFASSUNG VIII

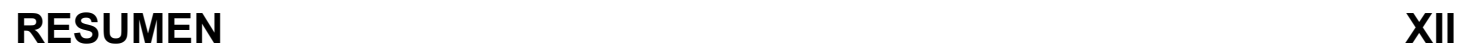

1 INTRODUCTION

1.1 GENERAL INTRODUCTION

1.2 FARMING SYSTEMS $\quad 4$

1.3 General Characteristics of Nicaragua 6

1.4 FOOD SUPPLY AND THE AGRICULTURAL SECTOR 9

1.5 SustainABILITY IN THE NiCARAgUAN HIGHLAND CONTEXT 11

$\begin{array}{ll}1.6 \text { HYPOTHESES } & 13\end{array}$

$\begin{array}{ll}\text { 1.7 Problem Setting and OUtLine } & 13\end{array}$

2 METHOD 15

2.1 StUdy AREA $\quad 15$

2.1.1 Geography 15

2.1.2 Population 16

$\begin{array}{ll}2.1 .3 \text { Economy } & 18\end{array}$

$\begin{array}{ll}2.1 .4 \text { Land Tenure } & 18\end{array}$

$\begin{array}{ll}2.1 .5 \text { Crops } & 19\end{array}$

$\begin{array}{ll}2.2 \text { Management } & 19\end{array}$

2.2.1 Animal and Livestock Production 24

2.2.2 Coffee and Forest 25

2.2.3 Choice of Community 26

2.3 MATERIAL FLUX ANALYSIS 26

2.4 STRATIFICATION OF FARMERS $\quad 28$

2.5 SYSTEM ANALYSIS FOR THE StATIONARY MODEL 31

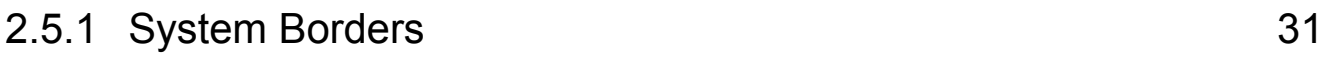

2.5.2 Indicators, Assessment Criteria and their Mathematical

$\begin{array}{lll}2.5 .3 & 0-S y s t e m \\ \end{array}$

$\begin{array}{ll}2.6 \text { DATA } & 39\end{array}$

2.6.1 Source and Collection $\quad 39$

$\begin{array}{ll}\text { 2.6.2 Quality } & 41\end{array}$

2.7 SensitiVIty ANALYSIS AND UnCERTAINTY PROPAgATION 42

2.8 MAIN ASSUMPTIONS $\quad 43$

3 QUASI-STATIONARY MODEL: STATUS QUO 45

3.1 FARMERS' STRATA 45 
3.1.1 Land Use $\quad 45$

3.1.2 Nitrogen Mining $\quad 51$

$\begin{array}{lll}3.1 .3 & \text { Self-Sufficiency } & 53\end{array}$

3.1.4 Covering Basic Needs - The Canasta Básica 56

$\begin{array}{ll}3.2 \text { REGION } & 58\end{array}$

3.2.1 Land Use, Population and Strata 58

3.2.2 Mass Fluxes and Nitrogen Metabolism 59

$\begin{array}{ll}3.2 .3 \text { Self-Sufficiency } & 63\end{array}$

$\begin{array}{ll}3.2 .4 & \text { Economy } \\ & 64\end{array}$

3.3 SENSITIVITY ANALYSIS $\quad 65$

3.4 CONFIDENCE INTERVAL OF THE RESULTS $\quad 67$

3.5 CONCLUSIONS TO THE StATUS QUO 68

3.5.1 Evaluation of the Status Quo: Strata 68

3.5.2 Evaluation of the Status Quo: Region 68

4 QUASI-STATIONARY MODEL: SCENARIOS $\mathbf{7 1}$

4.1 SCENARIOS CHOSEN

$\begin{array}{ll}4.1 .1 \text { Scenario } 1 & 71\end{array}$

$\begin{array}{lll}4.1 .2 & \text { Scenario } 2 & 72\end{array}$

$\begin{array}{ll}4.2 \text { Results SCENARIO } 1 & 76\end{array}$

4.2.1 Population and Strata $\quad 76$

$\begin{array}{ll}4.2 .2 \text { Land Use } & 78\end{array}$

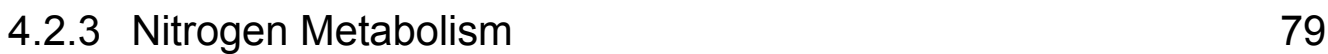

$\begin{array}{lll}4.2 .4 & \text { Self-Sufficiency } & 81\end{array}$

4.2.5 Economy 83

4.3 RESULTS SCENARIO $2 \quad 85$

4.3.1 Population and Strata $\quad 85$

$\begin{array}{ll}\text { 4.3.2 Land Use } & 85\end{array}$

4.3.3 Nitrogen Metabolism $\quad 86$

$\begin{array}{lll}\text { 4.3.4 Self-Sufficiency } & 87\end{array}$

4.3.5 Economy $\quad 88$

$\begin{array}{ll}4.4 \text { DISCUSSION OF SCENARIOS } & 89\end{array}$

5 DYNAMIC MODELING OF FARMING SYSTEMS 93

$\begin{array}{ll}\text { 5.1 DYNAMIC MODEL APPROACH } & 93\end{array}$

5.1.1 The need for a dynamic model 93

5.1.2 Goal of setting up a dynamic model 95

5.2 DESCRIPTION OF THE MODEL $\quad 95$

5.2.1 System Analysis 95

5.2.2 Model approach and calibration 98

$\begin{array}{ll}5.2 .3 \text { Assumptions } & 102\end{array}$

5.2.4 Calibration and Recalibration 102

5.2.5 Data and error estimation 104 
$\begin{array}{ll}\text { 5.3 COMPUTER PROGRAM } & 104\end{array}$

$\begin{array}{ll}5.4 \text { SCENARIOS } & 104\end{array}$

$\begin{array}{ll}\text { 5.4.1 Minimum Farms } & 105\end{array}$

$\begin{array}{ll}5.4 .2 \text { Monocultures } & 107\end{array}$

$\begin{array}{lr}5.5 \text { Evaluation Criteria } & 108\end{array}$

$\begin{array}{ll}5.6 \text { RESULTS } & 109\end{array}$

$\begin{array}{ll}\text { 5.6.1 Minimum Farms } & 109\end{array}$

$\begin{array}{ll}5.6 .2 \text { Monocultures } & 116\end{array}$

$\begin{array}{ll}5.7 \text { ERROR PROPAGATION } & 120\end{array}$

$\begin{array}{ll}5.8 \text { CONCLUSIONS } & 124\end{array}$

6 CONCLUSIONS $\quad 127$

$\begin{array}{lr}6.1 \text { OUTLOOK } & 129\end{array}$

$\begin{array}{ll}\text { ABBREVIATIONS } & 131\end{array}$

$\begin{array}{ll}\text { GLOSSARY } & 133\end{array}$

$\begin{array}{ll}\text { GEOGRAPHICAL NAMES } & 137\end{array}$

$\begin{array}{ll}\text { BIBLIOGRAPHY } & 139\end{array}$

APPENDICES

CURRICULUM VITAE 



\section{ABSTRACT}

Food resources become scarcer on a global scale. Should this trend continue, prices for food would inevitably start to rise and, on the long run, importing any significant proportion of staples must be regarded as impracticable for many developing countries. For nations with a rapidly growing population, considerable agricultural improvement and development will be indispensable if sufficient food of satisfactory quality and the energy to prepare it is to be provided. The understanding of the main agricultural regions as entities with specific resource endowments and constraints, characteristic socioeconomic patterns and cultural values is therefore crucial.

This study aims at answering the following key questions:

1. How can an agrarian region in a developing country be investigated and modeled to grasp the essential properties in its physical resource management?

2. What are the ecological constraints of such a region for survival on a long term?

3. How can we get insight into ecological and economic factors limiting different farming systems in developing countries?

The study area chosen is the agricultural region of San Dionisio in the Central Highlands of Nicaragua, which consists of 15 communities.

The method chosen was Material Flux Analysis (MFA). Due to the limited amount of published data an original field study was performed. In one community of San Dionisio, semi-structured interviews were carried out with randomly sampled farmers of four socioeconomic strata.

In a first step, the status quo was analyzed with a quasi-stationary model on farm level for each stratum and on a regional level. Indicators chosen were nitrogen, staple and 
energy self-sufficiency ${ }^{1}$. Moreover, the coverage of the basic consumer basket was assessed on household level.

The results of the quasi-stationary model show that nitrogen is mined primarily from the soils of the staple and the coffee $\&$ forest plots. This is mainly caused by the burning of crop residues for field preparation, the surface application of urea fertilizer and the high firewood consumption. A clear link exists between self-sufficiency as well as the coverage of the basic consumer basket and access to land. On a regional scale, current staple production is adequate to supply the population. Yet, the actual problem is firewood supply, which, for a steady state system without Hinterland, lies at roughly $70 \%$.

Analysis of the status quo was supplemented with two scenarios. The first Scenario describes the region after a population growth of $3 \%$ for the next 25 years. Land is distributed by partible inheritance. No emigration takes place. In the second scenario people adopt a new diet based mainly on animal products. These are produced entirely on the farm. A population threshold is assessed and the land is distributed evenly among the farmers. The surplus families leave the area.

In the first scenario energy lacks in $80 \%$ of the households, nitrogen is mined and hunger prevails. For the second scenario, the population has to be reduced to half the density of the status quo. Nitrogen mining can be stopped for staple production and self-supply assured. Yet, some nitrogen might be mined from pasture plots. Due to the fact that the basic consumer basket also includes basic education and medicine, it cannot be covered entirely with a system designed for auto-supply.

In a second step a time dependent, dynamic model was set up in order to investigate the functioning of the system and detect its crucial regulation factors. The central question proved to be how human strategies for agricultural systems can be modeled. Two groups of subsystems were set up: Those describing biological growth patterns

\footnotetext{
${ }^{1}$ For the definition of underlined words see glossary.
} 
(e.g. crop growth curves) and those representing agents' decision patterns (e.g. storage stock management). The design of the dynamic agent-based model revealed the importance of a profound system knowledge.

Two groups of scenarios were analyzed: The "minimum farms" and the "monoculture farms". The analysis of the first group included three variants: Finding farm size thresholds for a) the production of staples auto-supply and b) the purchase of minimum needs. In variant c) the impact of fertilizer application under ideal conditions was assessed for a farm with the size of a). The second group of scenarios examined the prevailing crops in form of tha monocultures. Calorie, protein and added value production and labor input was computed for maize, bean, coffee and livestock farming.

The results demonstrate the importance of farmers' strategies for farm management. Access to land, the chosen crop mix and labor force were found to be the most crucial regulating factors of farming systems. Thanks to dynamic modeling, interdependencies between these factors could be determined.

In conclusion, MFA proved to be a good instrument for investigating and modeling agrarian regions in developing countries. The analysis of the main ecological constraints shows that the region cannot survive on a long-term perspective under the current management. Changes in its production system are possible. Nevertheless, the options are strongly linked to macroeconomic conditions. Thus, further research should integrate ecological and economic factors. 


\section{ZUSAMMENFASSUNG}

In Zukunft droht weltweit eine Verknappung von Nahrungsmitteln. Sollte dieser Trend anhalten, hätte dies steigende Nahrungsmittelpreise zur Folge. Somit wäre es vielen Entwicklungsländern längerfristig nicht (mehr) möglich, ihren Grundnahrungsmittelbedarf durch Importe zu decken. Für Länder mit einer stark wachsenden Bevölkerung ist daher ein beträchtlicher Entwicklungssprung in der Landwirtschaft unumgänglich, falls a) genügend Nahrungsmittel von befriedigender Qualität und b) die Energie, um diese zuzubereiten, bereitgestellt werden sollen. Dies setzt jedoch das Verständnis landwirtschaftlicher Regionen als Einheiten voraus Einheiten, welche durch ein bestimmtes Angebot an natürlichen Ressourcen, spezifischen sozioökonomischen Mustern und kulturellen Werten charakterisiert sind.

Folgende Kernfragen wurden in dieser Studie angegangen:

1. Wie können landwirtschaftliche Regionen in Entwicklungsländern untersucht und modelliert werden, um die wesentlichen Eigenschaften ihres Ressourcenmanagements zu erfassen?

2. Welche ökologischen Faktoren könnten das Überleben solcher Regionen in Zukunft gefährden?

3. Wie können wir Einblick in ökologische und ökonomische Faktoren erhalten, welche die Entwicklung von Bauernhöfen verschiedener Typologien in Entwicklungsländern einschränken?

Das gewählte Studiengebiet San Dionisio ist eine landwirtschaftliche Region im zentralen Hochland Nicaraguas, welche aus 15 Dorfgemeinschaften besteht.

Die Studie basiert auf der Methode der Stoffflussanalyse (SFA). Wegen der geringen Verfügbarkeit von publizierten Daten wurde die Information direkt im Feld gesammelt. Dazu wurden halbstrukturierten Interviews mit Bauern aus vier sozioökonomischen Strati durchgeführt. Die Wahl der Gesprächspartnerinnen und partner erfolgte nach dem Zufallsprinzip. Anschliessend wurde in einem ersten Schritt 
das quasi-stationäre Modell für den Status Quo erarbeitet; einerseits auf Haushaltsebene für alle vier Strati, andererseits auf regionaler Ebene. Als Indikatoren dienten Stickstoff und die Selbstversorgung mit Grundnahrungsmitteln und mit Energie. Auf Ebene der Haushalte wurde zusätzlich die Deckung des Grundwarenkorbes berechnet.

Die Analyse des Status Quo zeigte, dass der Stickstoffabbau vor allem auf den Böden stattfindet, auf welchen Grundnahrungsmitteln und Kaffee angebaut werden. Dafür ist zu einem grossen Teil das Abbrennen von Pflanzenresten vor der Aussaat verantwortlich. Im Weiteren tragen das oberflächliche Auftragen des Harnstoffdüngers und der hohe Brennholzkonsum zu den Stickstoffverlusten bei. Ein klarer Bezug konnte zwischen dem Selbstversorgungsgrad bzw. der Deckung des Warenkorbes und dem Zugang zu Land festgestellt werden. Auf regionaler Ebene hingegen werden genügend Grundnahrungsmittel produziert, um die Bevölkerung zu ernähren. Falls für das System ein Fliessgleichgewicht angestrebt wird, ist der Brennholzbedarf jedoch nur zu 70\% gedeckt. Somit ist die Region zur Deckung des Energiebedarfs auf das Hinterland angewiesen.

Die Analyse des Status Quo wurde mit zwei Szenarien ergänzt. Das erste Szenario beschreibt die Region nach einem Bevölkerungswachstum von 3\% in den kommenden 25 Jahren. Dabei findet eine kontinuierliche Landverteilung unter Erben statt. Es findet keine Migration statt. Das zweite Szenario geht von einem geänderten Menüplan nach westeuropäischem Muster aus, welcher auf einer erhöhten Aufnahme von tierischen Produkten basiert. Letztere werden vollumfänglich auf dem Hof produziert. Für dieses System wird ein Bevölkerungsmaximum berechnet und das Land wird zwischen den Bauern aufgeteilt. Die überzähligen Familien verlassen das Gebiet.

Im ersten Szenario spitzt sich die Lage der Region zu: Brennholz fehlt in $80 \%$ der Haushalte und viele Leute hungern. Im zweiten Szenario hingegen, muss die heutige Bevölkerung mindestens um die Hälfte reduziert werden. Der Stickstoffabbau kann zwar für den Anbau von Grundnahrungsmittel gestoppt werden, findet aber 
möglicherweise in einem kleineren Masse auf den Weiden statt. Da der Warenkorb auch eine limitierte medizinische Versorgung und den Grundschulbesuch der Kinder umfasst, kann er im zweiten Szenario, welches auf Selbstversorgung ausgerichtet ist, nicht gesamthaft erworben werden.

In einem zweiten Schritt wurde ein zeitabhängiges, dynamisches Modell erstellt, um das Funktionieren des Systems zu erforschen und seine zentralen Regulierungsfaktoren zu ermitteln. Im Zentrum stand die Frage, wie menschliche Strategien für ein landwirtschaftliches System modelliert werden können. Zwei Gruppen von Subsystemen wurden gebildet: Jene, welche durch biologische Wachstumsfunktionen beschrieben werden können (z.B. Wachstumskurven von Feldfrüchten) und solche, die durch Entscheidungsmuster der Akteure bestimmt sind (z.B. Lagerbewirtschaftung). Das Entwerfen des Modells verdeutlichte die Wichtigkeit eines tief greifenden Systemverständnisses.

Zwei Szenariengruppen wurden untersucht: Die „Minimalhöfe“ und die „Monokulturhöfe“. In der ersten Gruppe wurden drei Varianten modelliert: Die minimale Grösse der Höfe wurde bestimmt, um a) genügend Grundnahrungsmittel zu produzieren und b) die minimalen Bedürfnisse der Familie (canasta mínima) zu decken. Im Szenario c) wurde der Einfluss eines erhöhten Düngereinsatzes auf die Produktion unter optimalen Bedingungen abgeschätzt. Der Hof hatte dieselbe Grösse wie in Variante a). In der zweiten Szenariengruppe wurden die wichtigsten Feldfrüchte der Studienregion in Form von Monokulturen untersucht. Als Indikatoren dienten Kalorien- und Proteinproduktion, sowie der geschaffene Mehrwert und der Arbeitsaufwand.

Die Resultate zeigen die Wichtigkeit der Strategien, welche von den Bauern gewählt werden. Als wichtigste Regulationsfaktoren entpuppten sich Zugang zu Land, Auswahl der Feldfrüchte und Arbeitskraft. Die Wechselbeziehungen zwischen diesen Faktoren konnten dank des dynamischen Modells erfasst werden. 
Zusammenfassend lässt sich festhalten, dass sich die SFA als taugliches Instrument für das Erforschen und Modellieren landwirtschaftlicher Regionen in Entwicklungsländern erwiesen hat. Die Analyse zeigt, dass das untersuchte Gebiet unter den heutigen Bedingungen langfristig nicht überlebensfähig ist. Änderungen im Produktionssystem sind möglich. Die Optionen sind jedoch eng mit makroökonomischen Bedingungen verknüpft. Deshalb sollte sich weitergehende Forschung mit dem Zusammenhang zwischen ökologischen und ökonomischen Faktoren beschäftigen. 


\section{RESUMEN}

Los recursos alimenticios se están volviendo cada vez más escasos a nivel global. Si esta tendencia persiste los precios de los alimentos incrementarían inevitablemente y, a largo plazo, sería imposible para una gran parte de los países en vías de desarrollo importar una parte significativa de granos básicos. En naciones con una población en rápido crecimiento el desarrollo y mejoramiento considerable de la agricultura será inminente si pretenden proveer a su población con suficiente alimento de calidad satisfactoria y con la energía necesaria para prepararlo. Por ende es crucial entender las regiones agrícolas más importantes como entidades con una oferta muy específica de recursos (naturales) y un patrón socioeconómico y cultural particular.

La meta de este estudio es responder a las preguntas siguientes:

1. ¿Cómo se puede investigar y modelar una región agrícola en un país en vías de desarrollo para entender las propiedades esenciales del manejo regional de los recursos (naturales)?

2. ¿Cuáles son las limitaciones ecológicas de dicha región para su supervivencia a largo plazo?

3. ¿Cómo podemos distinguir los factores ecológicos y económicos que limitan los sistemas agrícolas en países en vías de desarrollo?

El estudio se realizó en la región agrícola de San Dionisio, Matagalpa, Nicaragua. El municipio consiste de 15 comunidades.

Para este estudio se aplicó el método de Análisis de Flujos de Materiales (MFA por sus siglas en inglés). Este método, basado en la Ley de la Conservación de la Masa y la Energía consiste principalmente de los pasos siguientes:

1. Definir el sistema y sus límites, 2. establecer los flujos de materiales 3. determinar los indicadores adecuados para el análisis y 4. analizar el estatus quo y algunos escenarios 
Debido a la escasez de datos publicados, la información se recolectó en entrevistas semi-estructuradas con productores de cuatro estratos socioeconómicos. Los productores fueron escogidos al azar.

Primero se realizó un análisis quasi-estacionario a nivel de una finca "promedio" para cada uno de los estratos socioeconómicos y a nivel regional. Como indicadores para determinar el metabolismo de los recursos naturales de las fincas y la región se escogieron el nitrógeno así como la autosuficiencia de granos básicos y de energía. A nivel de finca se incluyó también su capacidad para asegurar la cobertura de la canasta básica.

Los resultados del modelo quasi-estacionario demuestran que el nitrógeno se mina principalmente en las parcelas de granos básicos así como en los cafetales y en el bosque. La causa predominante es la quema de residuos antes de la siembra, la aplicación superficial de fertilizante y el consumo elevado de leña. En cuánto a la autosuficiencia y la cobertura de la canasta básica, se puede demostrar claramente una correlación entre estos factores y el acceso a la tierra. A nivel regional, actualmente se producen suficientes granos básicos para abastecer a la población. No obstante, el problema principal es la provisión de leña que, en el caso de un sistema autosuficiente y sustentable, solamente cubriría el 70\% de la demanda.

El análisis del status quo se complementó con dos escenarios. El primer escenario estudió las consecuencias en la región si continuara un incremento de población semejante al actual, de alrededor del 3\%, por los próximos 25 años. La tierra se distribuiría entre los herederos y no habría migraciones. El segundo escenario asumió la introducción inmediata de una dieta nueva basada principalmente en productos animales. Éstos se producirían enteramente en cada finca. Estimando cuántas familias agrícolas podrían poblar la región bajo estas circunstancias, la tierra se distribuiría equitativamente entre ellas. Las familias restantes abandonarían la región.

Para el primer escenario los resultados del análisis muestran que al final de los 25 años la energía escasea en el $80 \%$ de los hogares y el hambre predomina. En cambio 
para el segundo escenario la densidad de población se reduce a la mitad de su valor en el status quo. La producción de granos básicos ya no mina el nitrógeno y la autosuficiencia queda asegurada. No obstante, posiblemente el nitrógeno se mina en las parcelas de potrero. Debido a que la canasta básica también incluye educación y medicamentos básicos, sus costos no pueden ser cubiertos con un sistema diseñado para la autosuficiencia.

En un segundo paso se elaboró un modelo dinámico para comprender mejor el funcionamiento del sistema y los factores cruciales de su regulación. Especial atención se dedicó a cómo se podían modelar estrategias humanas en sistemas agrícolas. Se diseñaron dos grupos de módulos: Los que pueden ser descritos por patrones biológicos (por ejemplo el crecimiento de los cultivos en la parcela) y los que dependen de las decisiones de los actores (por ejemplo el manejo del almacén).

Se analizaron dos grupos de escenarios: las fincas mínimas y las fincas de monocultivos. El análisis del primer grupo incluyó tres variantes: Encontrar el tamaño mínimo de una finca para a) ser autosuficiente en granos básicos y b) cubrir el costo de una canasta mínima propuesta en el análisis. En la variante c) se determinó qué impacto tendría un incremento en el uso de fertilizante bajo condiciones óptimas en comparación con la variante a). La meta del análisis del segundo grupo fue examinar los cultivos predominantes en forma de monocultivos de 1 ha para determinar su producción de calorías, proteínas y valor agregado, así como la mano de obra necesaria para trabajar dicha tierra. Ambos grupos se diseñaron para detectar los principales factores reguladores del sistema. Los resultados demuestran la importancia de las estrategias de los productores para manejar el sistema agrícola. Como factores reguladores más importantes del sistema se establecieron el acceso a la tierra, la combinación de cultivos y la fuerza laboral. Gracias a la utilización de un modelo dinámico se pudieron determinar las interdependencias entre éstos factores.

En conclusión, se pudo confirmar que el MFA es un buen instrumento para investigar y modelar una región agrícola en un país en vías de desarrollo. El análisis de las limitaciones ecológicas demostró que la región estudiada no puede sobrevivir a largo 
plazo bajo las condiciones actuales. Es posible cambiar sus sistemas de producción. No obstante, las opciones están estrechamente ligadas con las condiciones macroeconómicas. Por ende, un análisis complementario debería de incluir los vínculos entre factores ecológicos y económicos. 



\subsection{General Introduction}

Food resources become scarcer on a global scale as world population continues to rise, arable land resources dwindle and transition countries move up the food chain. Since 1961, world population has doubled from 3 to 6 billion people and it keeps growing. More than $95 \%$ of the future population increase is expected to occur in developing countries. How should food, fiber and energy be produced for an estimated annual population growth of 80 Million per year? In grain production alone this requires an increase of about 26 million tons per year (Gregory, P.J. and Ingram, J.S.I., 2000). Meanwhile, dietary patterns are changing rapidly in many countries in response to rising incomes, urbanization, changing consumer preferences, and government policy. Economic growth often leads to increased per capita food intake and especially to the consumption of more livestock products. Thus, between 1990 and 1996, China's grain consumption increased by some 40 million tons, with more than three quarters of it consumed as feed (Brown, 1997). Similarly, feed grain use is augmenting in many other Asian countries. If consumption patterns of certain social classes in developing countries shift towards the opulent menus of western countries, per capita land requirements will rise substantially as a result (van Vuuren and Smeets, 2000; Gerbens-Leenes, P.W. and Nonhebel, S., 2002). Nevertheless, usually not the entire population benefits from a nutrition richer in animal protein. Global trends indicate an increasingly unfair distribution of wealth among citizens of many developing countries and between nations on a global scale (Fang et al., 2002; Birchenall, 2001; Stiglitz, 2002; Fiallos, A., 2002). Hence, while a minor share of the world population is challenged by obesity, others cannot or barely satisfy their basic caloric needs. The latter are concentrated in the countries of the South (Figure 1.1). 


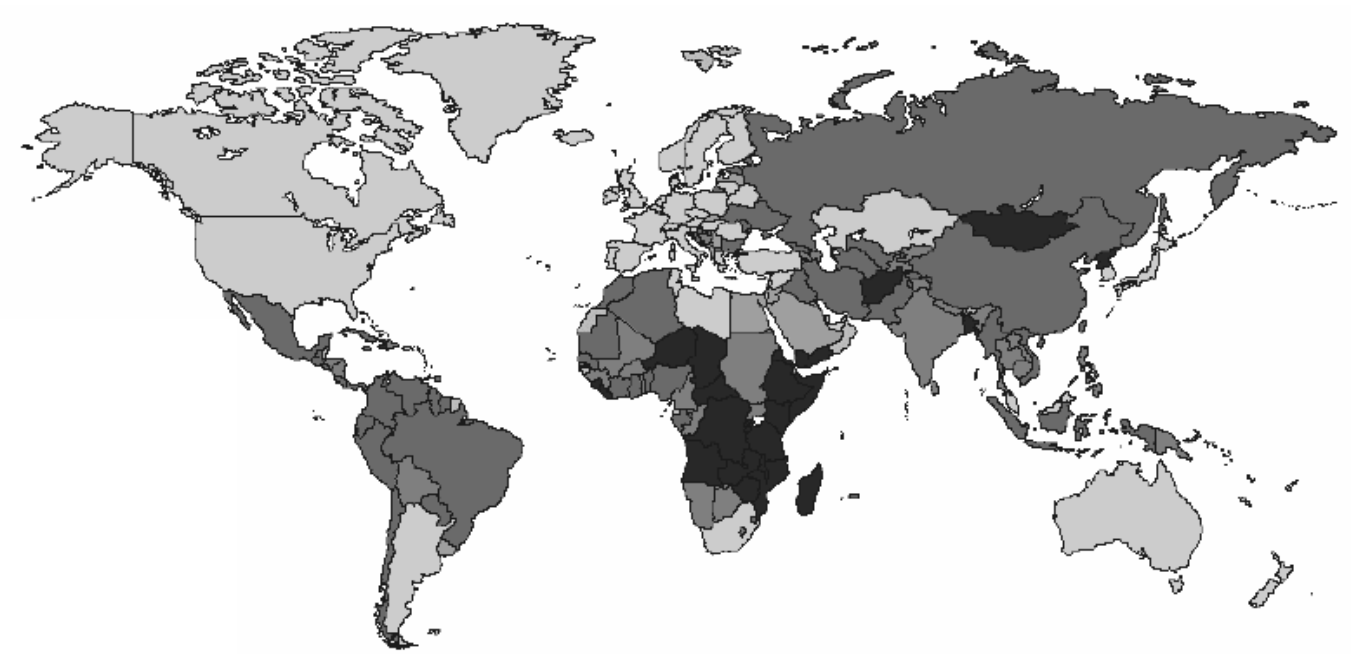

Figure 1.1: Prevalence of undernourishment on a global scale. Countries in the South are severely affected by undernourishment. Those with a very high incidence (color: black, $>35 \%$ of the population is undernourished) lie mostly in sub-Saharan Africa, while among those with a moderately high incidence (color: dark grey, 20-34\% of the population is undernourished) are the Central American countries Nicaragua and Honduras. (Source: http://www.fivims.org/index.jsp, Key words: Nicaragua, nutrition, food insecurity)

Thus, pressure on arable land resources increases due to population growth and changing consumption patterns. Yet, world land resources with appropriate climate and soil for rain-fed crop production are at their limits in many parts of the world (Webster and Wilson, 1998). Where this is not the case, most of the suitable land is under forest cover and part of a sensitive ecosystem. Thus, in many countries further expansion of the cropland is only possible if marginal and fragile land is taken under the plow. For that reason and due to inapt management land is being degraded (Zeleke and Hurni, 2001). Since 1945, 10\% of suitable global land reserves have succumbed moderate to extreme degradation. In Central America and Mexico alone, almost one fourth of the vegetated land is degraded areas (Oldeman et al., cited in PinstrupAndersen and Pandya-Lorch, 1994). For these reasons, increased food production from the expansion of crop area is not a sustainable solution for many countries. On the other hand, in the developed nations the maximum yields of grain crops seem to have been achieved as well. Since 1990 growth in the grain harvest has slowed dramatically (Brown, 1996). Plant breeders using traditional techniques have largely exploited the genetic potential for increasing the share of photosynthate that goes into seed. Harris and Kennedy (1999) investigated the pattern of yield growth for major 
cereal crops and presented evidence that it is logistic. This is consistent with ecological limits on soil fertility, water availability and nutrient uptake. Projections for food supply and demand in the twenty-first century based on a logistic model of growth imply that the world is close to carrying capacity in agriculture and that specific resource and ecological constraints are of particular importance at the regional level (Harris and Kennedy, 1999). In fact, global indicators of food security signal a tightening situation during the 1990s, as not only grain, but also other food stocks (e.g. fish) per capita decrease (Brown, 1997). Should this trend continue, prices for food would inevitably start to rise and, on the long run, importing any significant proportion of staples must be regarded as impracticable for many developing countries. The maintenance or even increase of food, especially staple production and the strengthening of their production base is therefore of uttermost importance. For nations with a rapidly growing population, considerable agricultural improvement will be indispensable if sufficient food of satisfactory quality is to be provided. Yet, this is a complicated task, as many problems have to be tackled at once. It has to be borne in mind that a considerable potential for increasing the production in developing countries lies in the hands of smallholders. Many of them farm with few or no external inputs and do rely mainly on man, sometimes on animal power. They often farm in fragile environments, such as mountainous areas prone to erosion. Smallholders are mostly marginalized in society. Many of them are poor, illiterate, lack organization structures and are, except for the election periods, seldom ever perceived by those in power. As a consequence, few of them have access to credits, technical assistance and food security, and resistance to shocks such as harvest losses and natural disasters is low. Thus, it is hard for these farmers to escape the vicious circle of poverty. Hunger and malnutrition, coupled with debilitating diseases, often reduce the energy and initiative of small farmers and are significant factors affecting agricultural productivity and development. Hence, in developing countries increase in production cannot be regarded independently from rural development. Furthermore, in order not to "compromise the ability of future generations to meet their own needs" (WCED, 1987), yields have to be increased in a sustainable way. Yet, recent studies in Africa indicate a generally unsustainable dynamism between population, agriculture and environment (Drechsel, 2001). Thus, the effect of population growth 
on economic sustainability and forest resources has been modeled for a village in the Tanzanian Usambara Mountains (Kaoneka and Solberg, 1997). The given system could economically sustain a population growth of $3 \%$ for a period of between 15 and 20 years. The authors furthermore showed that under these conditions deforestation was likely to be accelerated.

If sustainable development in its three dimensions - environmental, social and economic sustainability - is aimed at, several conditions have to be met: The resource management of the main agricultural regions as a whole must preserve the production factors, mainly soil and water. Furthermore, the regional farming systems have to be economically viable and should not contradict cultural values of the population. Additionally, access to food and other basic necessities, including energy, should be guaranteed for all the people living in the region. The energy demand for basic needs such as cooking, heating and transporting may be very low in simple farming systems, but a critical amount of energy is indispensable for the alleviation of hunger. Staples, on which poor people depend, are often inedible when raw and energy is needed for food preparation and preservation.

The understanding of the region as an entity with specific resource endowments and constraints, characteristic socioeconomic patterns and cultural values is therefore crucial. This again is based on a profound knowledge of the regional farming and the farmers' livelihood systems.

\subsection{Farming Systems}

A farming system is defined as a population of individual farms with broadly similar resource bases, enterprise patterns, household livelihoods and constraints (Dixon et al., 2001). Similar farms can be grouped into farming systems on the regional, national and global level (Figure 1.2). Depending on the focus, an analysis can be carried out on either level and encompasses either a few dozen or many millions of households. The delineation of the major farming systems provides a useful 
framework within which appropriate agricultural development strategies and interventions can be determined. (Dixon et al., 2001).

In Central America the predominant farming system is called the maize-beans (Mesoamerican) farming system. It occupies mostly upland areas from the Panama Canal to the highland plateaus of Guatemala and Central Mexico. The regions belonging to the Mesoamerican farming system lie between 400 and 2'000 m.a.s.l. The precipitation ranges from 1'000 to 2'000 mm per annum. Most soils are of volcanic origin and relatively fertile, but on slope lands they tend to be thin and subject to erosion (Dixon et al., 2001). The region's main characteristics are the significant proportion of indigenous population, the central role of maize (Zea Mais L.) and beans (Phaseolus vulgaris L.), the small size of holdings, the high degree of on-farm consumption of production and the importance of seasonal migration of wage labor to lowland agricultural and coffee estates.

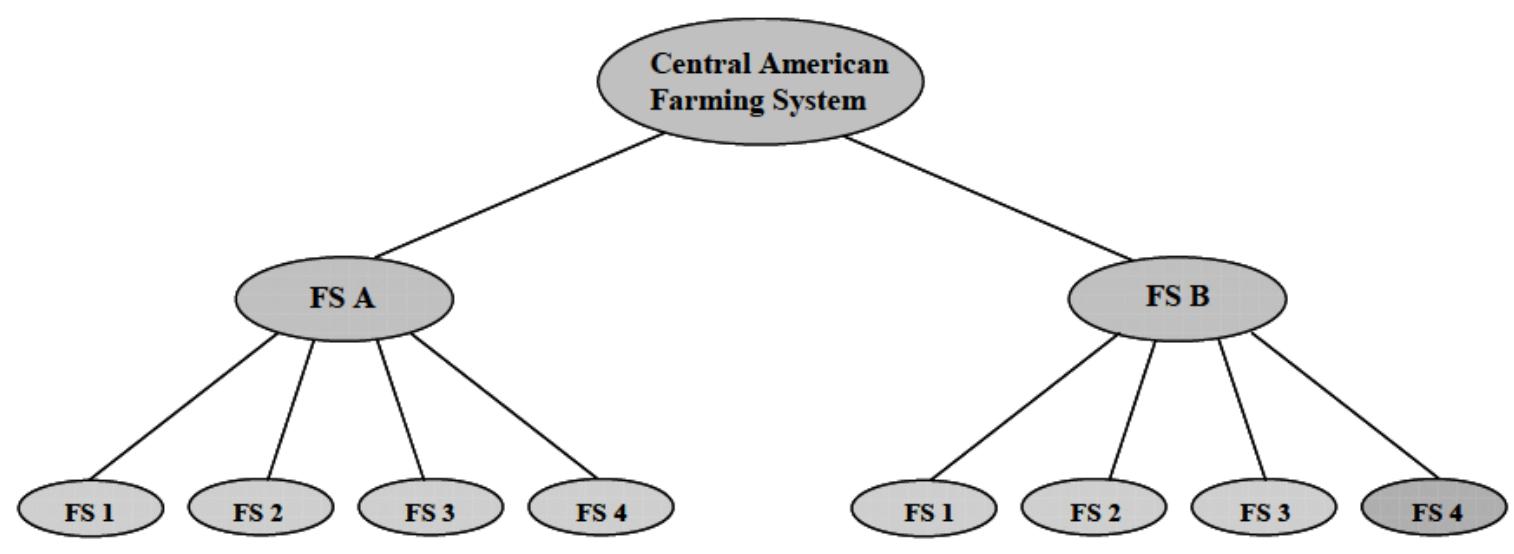

Figure 1.2: The hierarchy of farming systems (FS): Farms with similar resource base, enterprise patterns, household livelihoods and constraints can be grouped into farming systems on a regional, national or global level.

Among the Central American countries, Nicaragua was chosen for carrying out the study. This was on one handy due to the author's broad experience in this country, on the other hand to the contacts previously established with other research institutions. 


\subsection{General Characteristics of Nicaragua}

With a territory of $120350 \mathrm{~km}^{2}$ (Table 1.1), not including the area of the big lakes, Nicaragua is the largest country in Central America. It lies between $10^{\circ} 45^{\prime}$ and $15^{\circ} 6^{\prime}$ and shares its frontiers with Honduras in the North and with Costa Rica in the South (Figure 1.3).

\begin{tabular}{ll}
\hline General Characteristics of Nicaragua & \\
\hline Area & $120350 \mathrm{~km}^{2}$ \\
Population & 5.2 million (2001) \\
Population Growth & $2.7-3.2 \%$ per year (according to source) \\
Literacy Rate & $80 \%$ \\
Life Expectancy & 69 \\
Gross Domestic Product (GDP) & 410 US\$/a \\
$\%$ of GDP: Agriculture & $32 \%(2001)$ \\
Ethnic Groups & Mestizos, indigenous, black, European descent \\
\hline
\end{tabular}

Table 1.1: General Characteristics of Nicaragua. Nicaragua is the biggest Central American country. Its population density is low, population growth high. After Haiti Nicaragua is the poorest country in the Western hemisphere (Sources: various).

Alike its neighbors, Nicaragua borders on the Pacific and the Atlantic Ocean. The country consists of three macro regions: the Pacific Region, the Central Highlands and the Atlantic Coast. The Pacific Region ranges from the Pacific Coast to the two big lakes. It contains the most fertile soils which are of volcanic origin. Indeed, its most pronounced landmark is the volcanic chain stretching from North to South, of which several volcanoes are still active. During the cotton boom from the 50's until the 80's this crop was cultivated on wide ranges of the flat land. The introduction of cotton caused an exodus of smallholders, which moved to more fragile lands in Central Nicaragua. Now, in the Pacific Region mainly sesame, peanuts and sugarcane are grown. The most important cities, including the capital Managua, are localized there. 


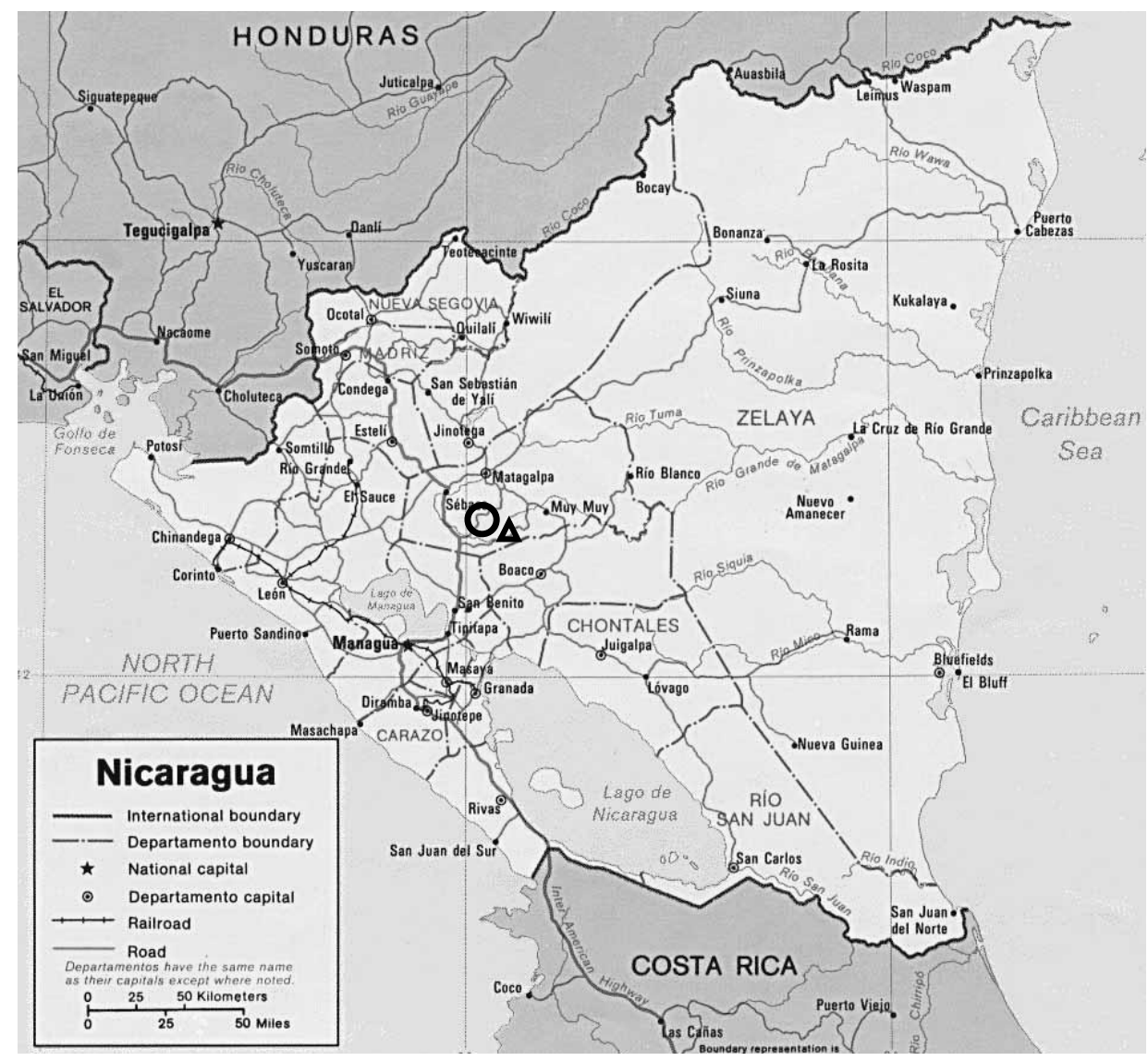

Figure 1.3: General Map of Nicaragua and localization of study area: The municipality of San Dionisio, marked with a $\mathbf{O}$ lies in the central highlands of Nicaragua in the department of Matagalpa. $\Delta$ marks the location of Esquipulas. (Source: www.1uptravel.com/worldmaps/ nicaragua2 html)

The Central Highlands are the coffee producing center of Nicaragua due to mountains as high as $2000 \mathrm{~m}$ and the favorable climate. They also provide considerable amounts of livestock products. The topography of the region is rugged and accessibility is not adequate in many places. In the Pacific region and the Central Highlands Spanish is spoken and the majority of the population are mestizos.

The Atlantic Region is relatively flat and is covered by tropical rainforest. The climate is wet all year round. Often rivers are the only route of communication. The Atlantic Coast is characterized by a low population density of mainly indigenous peoples (Miskito, Sumu, Rama) and a Creole English speaking black population. It is the poorest region of Nicaragua.

Of the 5 million Nicaraguans, one fourth lives in the capital Managua. (INEC, 2003). In the rest of the Pacific region, in the Central Highlands and the Atlantic Coast 
resides $32 \%, 31 \%$ and $12 \%$ of the Nicaraguan population respectively. According to the Nicaraguan National Institute of Statistics and Census, the demographic growth lies at 3.2\% per year (INEC, 2003) (Figure 1.4).

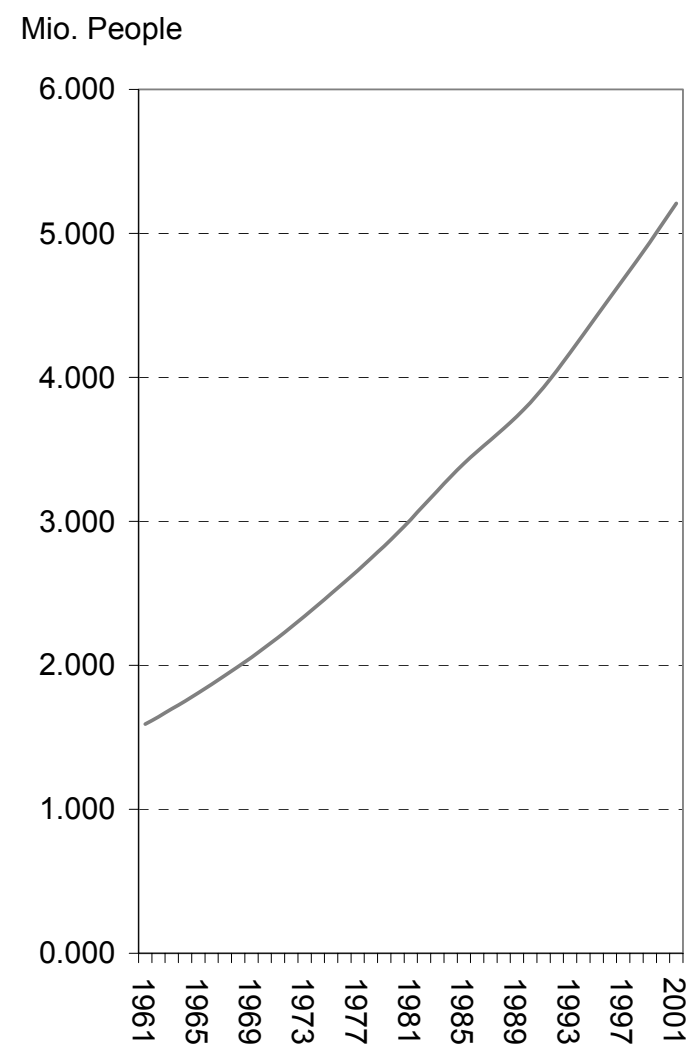

Figure 1.4: Population growth in Nicaragua (1961-2002). (Source: FAOSTAT). Since 1961 the population of Nicaragua has more than tripled. Changes in reproductive behavior are slow and occur mainly among educated families in the cities.

It is especially pronounced in rural areas, where it is as high as $4.4 \%$, although it has come down from $5.4 \%$ in 1998. This is reflected by the low average age of Nicaragua's inhabitants which lies around 24 years $^{2}$ (INEC, 2003). Nicaragua is the second poorest country of the Western hemisphere after Haiti. Its GDP is 410 US\$/cap, roughly one fifth of the adult population is illiterate (INEC, 2003), while $40 \%$ has not passed fourth grade. The life expectancy rate is 69 years.

\footnotetext{
${ }^{2}$ Half the Nicaraguans are younger than 18 years old.
} 


\subsection{Food Supply and the Agricultural Sector}

While in the 1980's the declared goal of the revolutionary government was food autarchy (Austin et al., 1985), in the 1990's staple production was neglected by the neo-liberal governments as it had been before the revolution (Godoy and Hockenstein, 1992). As a consequence it is hard for farmers to get credits (Fiallos, 2002; Davis et al., 2001), especially for food crops. Instead, non-traditional agricultural products, like tropical fruit for export, are propagated and mainly agro-industry is supported with loans. Nonetheless, at present Nicaragua still produces roughly $70 \%$ of the cereals, $86 \%$ of the starchy roots (cassava, potatoes) and $100 \%$ of the pulses needed for national consumption (FAO, 2002) (Table 1.2).

\begin{tabular}{lll}
\hline Foodstuff & Production [\%] & Import [\%] \\
\hline Cereals & 70 & 30 \\
Pulses & 100 & $\approx 0$ \\
Starchy Roots & 85 & 20 \\
Vegetable Oils & 24 & 76 \\
Milk & 110 & 30 \\
\hline
\end{tabular}

Table 1.2: Food production in Nicaragua. (Source: FAOSTAT, 1998-2000). Nicaragua produces a great share of its own food, such as pulses, cereals and starchy roots. Milk is imported as powder milk, while at the same time part of the domestic dairy production is exported to neighboring countries as cheese. The country depends heavily on imports in the case of vegetable oils.

The major imports consist of wheat (17\% of the cereals consumed), potatoes $(20 \%$ of the starchy roots consumed) and vegetable oils (76\%). Furthermore, vegetables are imported to a great extent. Milk is imported (about 30\% of the production), mainly as powder, while domestic dairy products (e.g. cheese) are exported (36\% of the production). The main agricultural exports consist of coffee, sugar and beef. Thus, Nicaragua does not produce a surplus of staple foods for export. On the contrary, as it is susceptible to natural disasters such as hurricanes, floods, droughts and earthquakes, there are marked fluctuations in domestic food supply. Significant amount of foodstuffs have to be imported or are received as donations after these incidences, as depicted in Figure 1.5. 


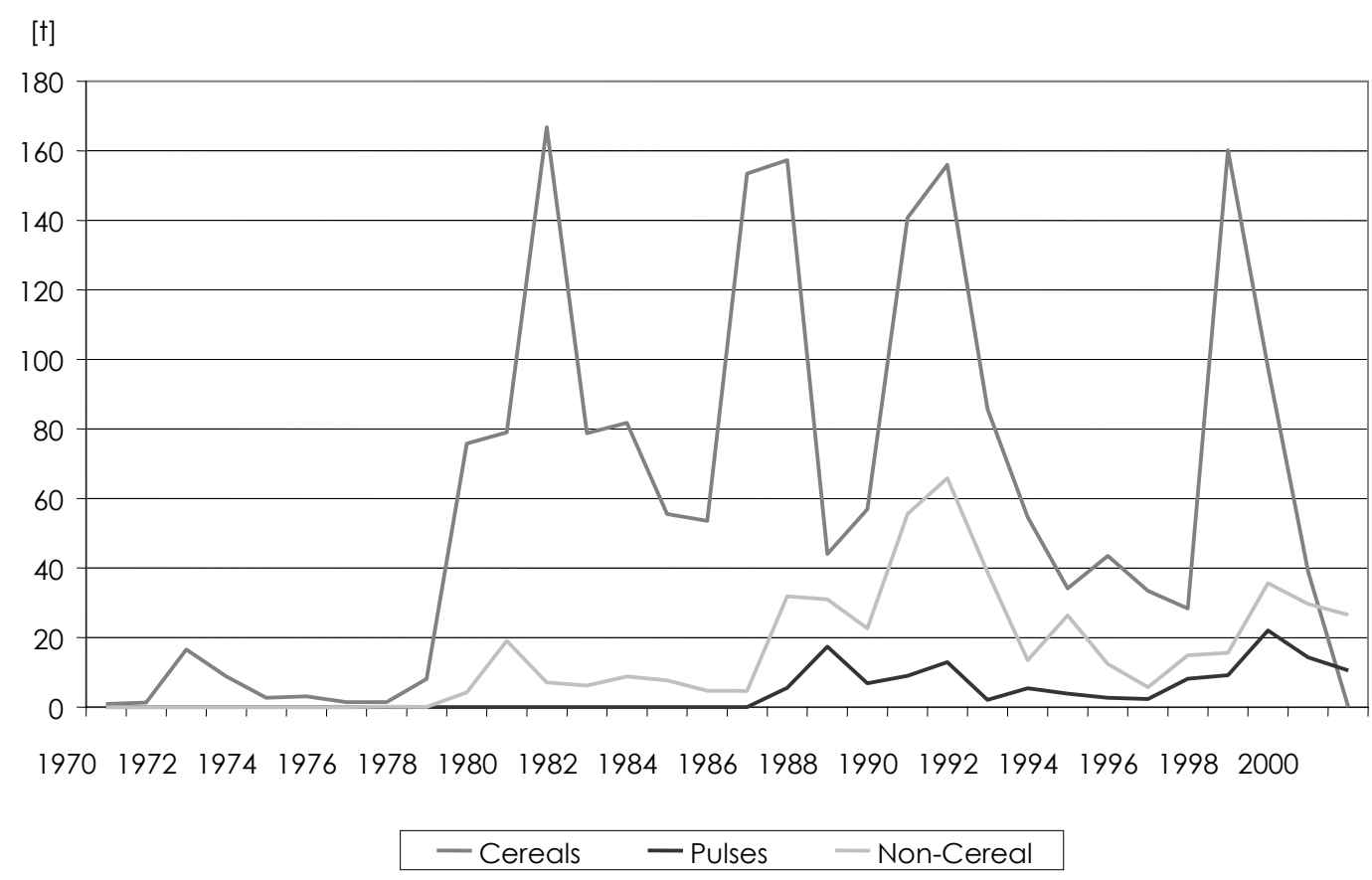

Figure 1.5: Food imports into Nicaragua. (Source: FAOSTAT). Crises and natural disasters (e.g. 1972 earthquake in Managua, 1979 revolution, 1998 hurricane "Mitch") can be clearly discerned.

Mostly, the food aid is supplied from abroad and not bought on the Nicaraguan market. This has a negative effect on national farmers, as they cannot profit from higher prices. Yet, it protects consumers in urban areas from raising expenses. The agricultural sector has also been struck by structural reform programs and low prices on the world market. Since the establishment of free trade agreements in the 90's, Nicaragua's grain markets are confronted with fierce competition from abroad. At the same time the costs of agricultural inputs have risen, diminishing the profitability of farmers' activities (Artola González, 1997).

The considerable drop of coffee prices in 2000/01 had further serious effects on the country's economy: coffee contributes $7.2 \%$ to the GDP, $24.4 \%$ to the agricultural GDP and makes up for $23 \%$ of exported goods. Its collapse hit 40'000 small farmers, 350'000 seasonal and 70'000 permanent workers (Flores et al, 2002), most of them in the Central Highlands. A further general problem is the marketing chain of agricultural products, which involves many intermediaries and is characterized by high costs and low market transparency (Spoor, 1995). Transportation costs are high, for the road quality is poor in many grain and coffee producing areas. 


\subsection{Sustainability in the Nicaraguan Highland Context}

Although yields tend to be low, it has been acknowledged that agriculture on steep slopes of tropical America makes an important contribution to national food security (Posner and McPherson, 1982). Yet, the agricultural production in mountainous areas faces many challenges, for instance high vulnerability to natural disasters and jeopardized ecological sustainability. The former became evident once more when hurricane "Mitch" passed in 1998 and caused considerable losses not only of harvest and fertile land, but also among the population. In addition, infrastructure like streets and bridges were damaged, leading to further economic disadvantages for the farmers due to higher transportation costs. Central American mountain agriculture is often not ecologically sustainable. Cropping on steep slopes accelerates erosion processes, especially because no soil and water conservation measures are taken. Thus, for Region VI (departments of Matagalpa and Jinotega) average annual soil loss is estimated to lie around $125 \mathrm{t} / \mathrm{ha}$ *a for staple crops and $107 \mathrm{t} / \mathrm{ha}$ *a for coffee (Marín Castillo cited in Alfsen et al, 1996). Nevertheless, experts consider these figures to be far too high (Hurni, H., personal communication), especially for coffee plots. Cropping land is extended by the reduction of forest area, pesticide application rates are relatively high and in many cases farmers "take advantage of the cheap soil fertility" (Artola González, 1997). This means that they grow their crops in the fertile mountainous zones without addition of any fertilizer until the production falls below a certain threshold. Farmers may well be aware of this fact, but for them, sustainability first of all means short term survival as they are subject to severe economic constraints (e.g. Maldidier, C. et al., 1997). In Nicaragua, $76 \%$ of the rural population lives in poverty (UN Habitat, 2002). The poverty of region VI is among the highest of the country (Nitlapán-UCA, 1997). Malnutrition is widespread, especially in the period before harvest. Food insecurity is aggravated by significant variability in coffee prices from year to year. Thus, in July 2001 almost 900 hungry persons gathered in a central park of Matagalpa (Rocha, 2001). These landless agricultural workers had been dismissed and driven away from the coffee hacienda, where they had been living in shanties most of their lives. Now they had nowhere to go and nothing to live off. Although the land owners carry a lower risk to find themselves in 
a similar situation, most of them are under pressure to repay the loans for seeds and chemical inputs ${ }^{3}$. Thus their property is constantly threatened by debt loads, bad harvests and low market prices. At present, as much as 3'000 coffee producers may be close to bankruptcy and about to lose their land because they cannot repay their loans (Flores et al, 2002).

After economic survival, the second priority for farmers is to secure the future of their children by inheriting their land and thus they are also concerned about the long-term sustainability of their management. Farmers are, for instance, well aware of the deteriorating environment - not only on their farms (Calderón et al, 2001). Yet, in many cases the struggle for daily survival limits their options. Therefore, for durable development both the ecological and economic viability of the system have to be ensured.

If either one is not guaranteed, farmers will migrate to urban areas or to the agricultural frontier. Both cases are not desirable for the actual national development: At present, roughly half of Nicaragua's population lives in cities (UN Habitat, 2002). The rapid urbanization has led to a boosting unemployment and crime rate. Public investment in infrastructure lags far behind growth of the cities. The situation is not likely to change in the near future. Thus, Nicaraguan peasants moving to the city are prone to becoming inhabitants of the slums under infrahuman conditions. The agricultural frontier on the other hand has reached Bosawas, Nicaragua's natural reserve of unique features, where the constant influx of newcomers from central Nicaragua leads to conflicts with the native tribes and to the degradation of the ecosystem (Howard, S., 1998; Maldidier, C. et al., 1997). As problems are similar in other Central American countries (Cherrett, 2001; Shriar, 2002), ways have to be found to improve the livelihood of peasants without degrading the natural resources. For this, potentials and limitations of their common farming management system have to be detected.

\footnotetext{
${ }^{3}$ Inofficially parts of these credits are also used for consumption during the months June and July.
} 


\subsection{Hypotheses}

This study is based on the following hypotheses:

- Resource potentials and limits of the agricultural sector of a country are best investigated at a regional level.

- For the understanding of the region a bottom-up approach is necessary. Groups of similar farms are therefore the basic study unit.

- Agriculture in Central American highlands is neither ecologically, nor economically or socially sustainable.

\subsection{Problem Setting and Outline}

There are three key questions to be answered:

1. How can an agrarian region in a developing country be investigated and modeled to grasp the essential properties in its physical resource management?

2. What are the ecological constraints of such a region for survival on a long term?

3. How can we get insight into ecological and economic factors limiting different farming systems in developing countries?

This study proposes a methodology for the assessment of the potentials and limitations of an agricultural region. The focus lies on current regional and farm resource management and explore them under two scenarios. The analysis of the nitrogen metabolism is used as an example of one possible steering parameter for sustainable farm and regional resource management. Additionally, food and energy security are estimated at farm and the regional level, while the coverage of the basic needs is determined at farm level only. Last but not least, some of the main characteristics of the region like demographic features, social stratification and some basic economic conditions are assessed. 



\section{METHOD}

\subsection{Study Area}

\subsubsection{Geography}

One important agricultural zone in Nicaragua is the so-called grain basket in the strip between Matagalpa and Esquipulas, of which the municipality of San Dionisio is the main staple producer (FAO, 1995). San Dionisio, in the department of Matagalpa, is located in the central hillside range of Nicaragua, about $160 \mathrm{~km}$ northeast from the capital Managua (Figure 1.3). The municipality consists of 15 rural communities (Figure 2.1) and the county's capital is also called San Dionisio. It covers an area of about $173 \mathrm{~km}^{2}$ and has a hilly topography with steep slopes - in the 7 communities investigated in a baseline study ${ }^{4}$, on more than $70 \%$ of the land the slopes are steeper than 30\% (Leemann, E., forthcoming) - and altitudes between 350 and 1250 m.a.s.1. The climate is semi-arid with precipitations from 1100 to $1600 \mathrm{~mm} / \mathrm{a}$ from May to October. In August the precipitation pattern shows a short interception called canícula with diminished rainfall. The temperature ranges from 22 to $25^{\circ} \mathrm{C}$ all year round. Local soil types are Andisols, Alfisols, Inceptisols, Entisols, Mollisols and Vertisols (Rodríguez Ibarra, I., personal communication).

San Dionisio is connected by a gravel road with the departmental capital Matagalpa and the town Esquipulas. There are several buses a day running from these two locations to San Dionisio, but fares are high ${ }^{5}$ and transport velocity is slow. The latter is partly due to the impact of climate on the road quality. A health care center is located in the town of San Dionisio and in some communities there are health posts.

\footnotetext{
${ }^{4}$ In 2000 a baseline study called Sustainable Development Appraisal (SDA) was carried out in 7 of the 15 communities by the Swiss Federal Institute of Technology and the University of Berne. Results are hitherto unpublished.

${ }^{5}$ In the year 2000 the return trip to Matagalpa cost C\$25, which corresponds to the daily wage of an agricultural worker.
} 
Primary schools are found in all of the communities, but a secondary school exists only in Susulí (until $3^{\text {rd }}$ year of totally 5 years) and in the town of San Dionisio.

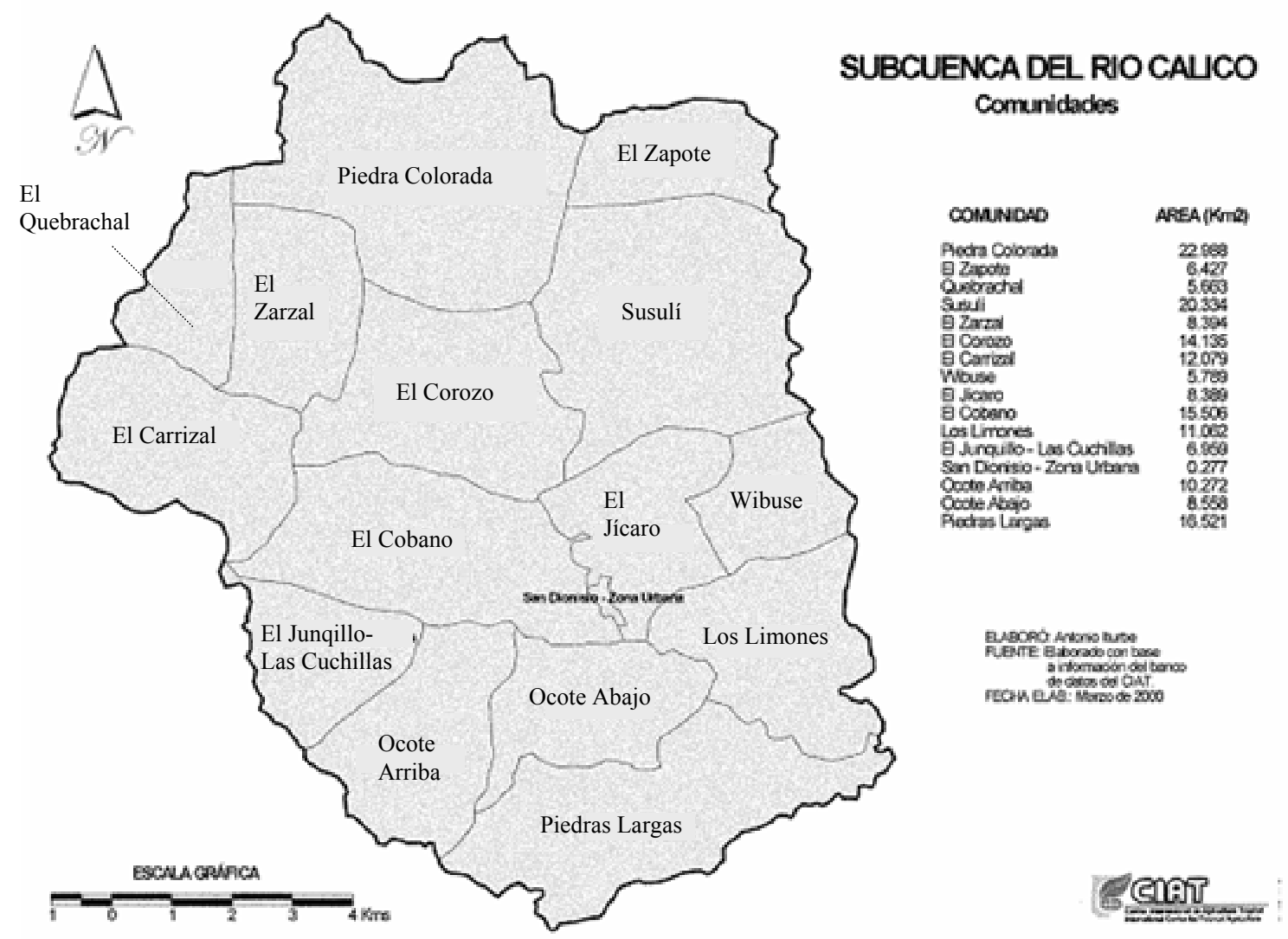

Figure 2.1: The municipality of San Dionisio and its 15 communities. The municipality of San Dionisio consists of 15 communities with varying sizes. Seven of them were analyzed in a baseline study by ETHZ/University of Berne in 2000 (unpublished data), where the limits of the communities, and thus their size, had to be adjusted (Source: CIAT-Laderas).

\subsubsection{Population}

In the official census of 1995 the population of the municipality of San Dionisio was estimated to be 16'000 (SETEC, 2001), but figures vary substantially with the source (Baltodano et al. 1997; INIFOM, 2002). About 89\% of the population is estimated to live in rural areas, the rest lives in the only town. The municipality of San Dionisio ranks among the very poor in Nicaragua: $78 \%$ of the inhabitants are poor, of which 
about half are considered to live in extreme poverty (SETEC, 2001). Of the latter, $90 \%$ live in rural areas, where almost all people are farmers. As a consequence of poverty, the nutritional status of the inhabitants is bad. In San Dionisio the figure of malnourished children below 6 years was roughly $20 \%$ in 1995 , while $30 \%$ of them were at risk (Figure 2.2) (FAO, 1995).

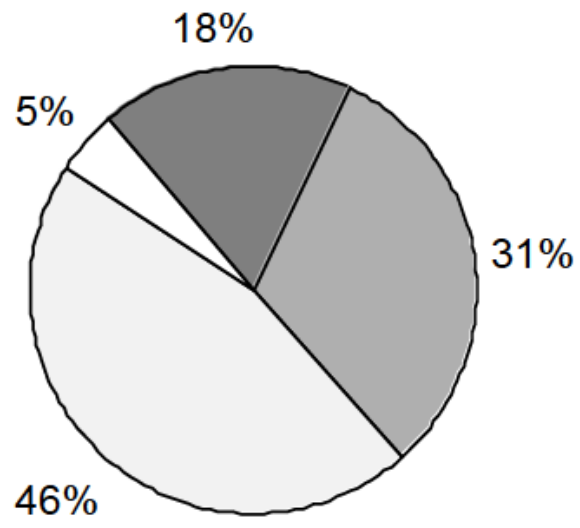

$\square$ Malnourished $\square$ At risk $\square$ Normal $\square$ Overweight

Figure 2.2: Malnourishment of Children in the municipality of San Dionisio. Malnourishment and children at risk are widespread in the area. Only $23 \%$ of the children are well or overweight.

(Source: FAO, 1995).

Due to the harsh economic conditions of the last years this figure has probably risen. This assumption is supported by the fact that the number of undernourished persons has risen in the whole country. At present a total of $20-34 \%$ of the Nicaraguan population is malnourished (FIVIMS, 2003). As the poorest people live predominantly in rural areas, there the actual percentage of malnourished persons is higher than the national figures (FAO, 2001). As the prevalence of health problems is tightly linked to malnourishment, infectious diseases are highly common in the study region. 


\subsubsection{Economy}

The economy of San Dionisio depends essentially on agricultural production, mainly on staples, coffee and livestock. "Industries" like bakeries, tailors and mills are scarce (FAO, 1995). As a consequence, the unemployment rate in the municipality and also in the town of San Dionisio is high. In the rural communities almost everybody is employed within the agricultural sector. Labor force is needed mainly for work peaks like sowing and harvesting staples and coffee. The latter crop provides additional work - primarily for women - in the coffee mill of San Dionisio. During the dry season many people migrate to haciendas in other parts of the country or to Costa Rica looking for temporal employment. Some women of the region work all-year round in the textile industrial free zone ("Zona Franca") of Sébaco, at 2-3 hours of one-way traveling time. The jobs are poorly remunerated and linked to big sacrifices (long working days, arduous working conditions, fatiguing everyday trips), but alternatives are scarce. Women may also find employment as maids in the city, but this separates them from their families for long periods.

In San Dionisio there are no banks or credit institutes. Of the Non-Governmental Organizations (NGOs) present few give production credits to farmers and their number is constantly diminishing. In the community of Susulí there is a purchasing cooperative called Banco de Granos ("grain bank"). This association buys the maize at the current official market price and stores it until the latter has increased. When the grain is sold, most of the additional revenue is given to the producing farmers, according to the amount of maize they deposited.

\subsubsection{Land Tenure}

The municipality of San Dionisio is a typical region of small-scale agricultural production: $70 \%$ of the farms are smaller than 6.5 ha (FAO, 1995). The land is formal property of the Indigenous Community of Matagalpa, which legally entitles the farmers to the right of usufruct against a small yearly tax. This right can be sold and inherited freely, yet the transfer has to be carried out through the Indigenous Community. A problem of land tenure in Nicaragua is the lack of legal land titles due to the costs associated with their purchase. Without this document the difficulties to 
obtain credits increase considerably. None of the agricultural cooperatives founded in the 1980's has survived. The land was distributed among their members and although legally some cooperatives still exist, they do not carry out any activities anymore. Currently the share of landless farmers is fairly high again in some communities. Sharecropping and renting land is common.

\subsubsection{Crops}

Almost all farmers grow the staples maize and beans. Landless and small farmers' activities concentrate mainly on these crops, while medium and big farmers may additionally raise livestock and grow coffee. Only few farmers opt for other crops like sorghum, tomatoes, potatoes or sugarcane. Farmers growing sorghum usually own livestock and ample land resources and use the grain as additional fodder. When smallholders cultivate sorghum, this often indicates a crisis ${ }^{6}$, such as e.g. the loss of the bean harvest, as this food grain is not popular for human consumption. Vegetables are seldom grown. Considerable investments are necessary because of high pesticide and fertilizer use and material costs (e.g. a hose, stakes and string for tomatoes). Moreover, water is scarce in parts of the area and thus irrigation in Susulí is banned ${ }^{7}$. Vegetable growing during the dry season, when there are less pests and higher prices, is therefore impossible. Sugarcane is sometimes produced in combination with livestock rearing, as some byproducts can be used as fodder.

\subsection{Management}

Staple crops are grown in both of the two harvest seasons primera (from May until August) and postrera (from September until December). Some farmers cultivate beans in a third harvest season called apante in the mountainous areas of Matagalpa towards the Atlantic Coast ${ }^{8}$. The investment for workforce, seeds, transport and overnight stay in the area are high so that only wealthier farmers can afford it. Furthermore, the land is sharecropped and thus half of the harvest goes to the land

\footnotetext{
${ }^{6}$ Sorghum needs little water to grow and is therefore apt to be cultivated in arid areas, dry years or if part of the growth stage takes place in the dry season.

${ }^{7}$ In other communities of the municipality irrigation is permitted.
} 
owner. Thus, for a small area apante does hardly pay off. In San Dionisio, there is a clear preference for planting maize and some beans in primera, while in postrera mostly beans are grown. The maize is planted with the first rains (Figure 2.3). At the beginning of August baby maize cobs are harvested. Only one cob is left at each plant. Farmers claim that this way the latter develops much bigger. Once ripe, the maize is left on the fields to dry, and at the end of August or beginning of September its leaves are cut and beans are intercropped for postrera. While the beans of primera are mainly harvested in August, in postrera the bean harvest takes place at the end of November or the beginning of December. The farmers explain their cropping pattern with the precipitation distribution: while the rains are quite constant between May and August, in the second half of the rainy season precipitation is more irregular. According to the farmers, after a certain developmental stage, for beans a drizzle is enough, while maize needs a major quantity of water to grow. Thus maize is cultivated in primera when rains are usually abundant, while beans are grown in both cropping seasons. Some farmers claim that maize, if well fertilized and with sufficient moisture, gives a more constant yield than beans. Yet, this contradicts official harvest figures from the Central Bank of Nicaragua, which show considerable oscillations for both staple crops. However, maize yields roughly twice the calories of beans per ha. These are highly susceptible to climatic variation. If there is a drought during the flowering period the harvest is lost. If there is too much rain, the same occurs as a cause of fungal diseases. At the same time bean leaves tend to be attacked by snails, which often cause total loss of the harvest. A further danger is rains during the canícula period when beans are harvested. As the beans are rooted out and left on the fields to dry, they germinate with wet weather and are not marketable anymore.

In San Dionisio, agriculture is not mechanized. Agricultural labors are mostly done by hand, seldom with a team of oxen. For field preparation almost all farmers were found to burn crop residues and weeds before they apply the herbicide Gramoxone after sowings. Mineral fertilizers are widely used for growing maize, but none is applied to bean crops. The reason for this is that maize harvest drops considerably if no nitrogen is applied, while beans still give a reasonable yield.

\footnotetext{
${ }^{8}$ There the climate is more humid, thus a third cropping season is possible.
} 


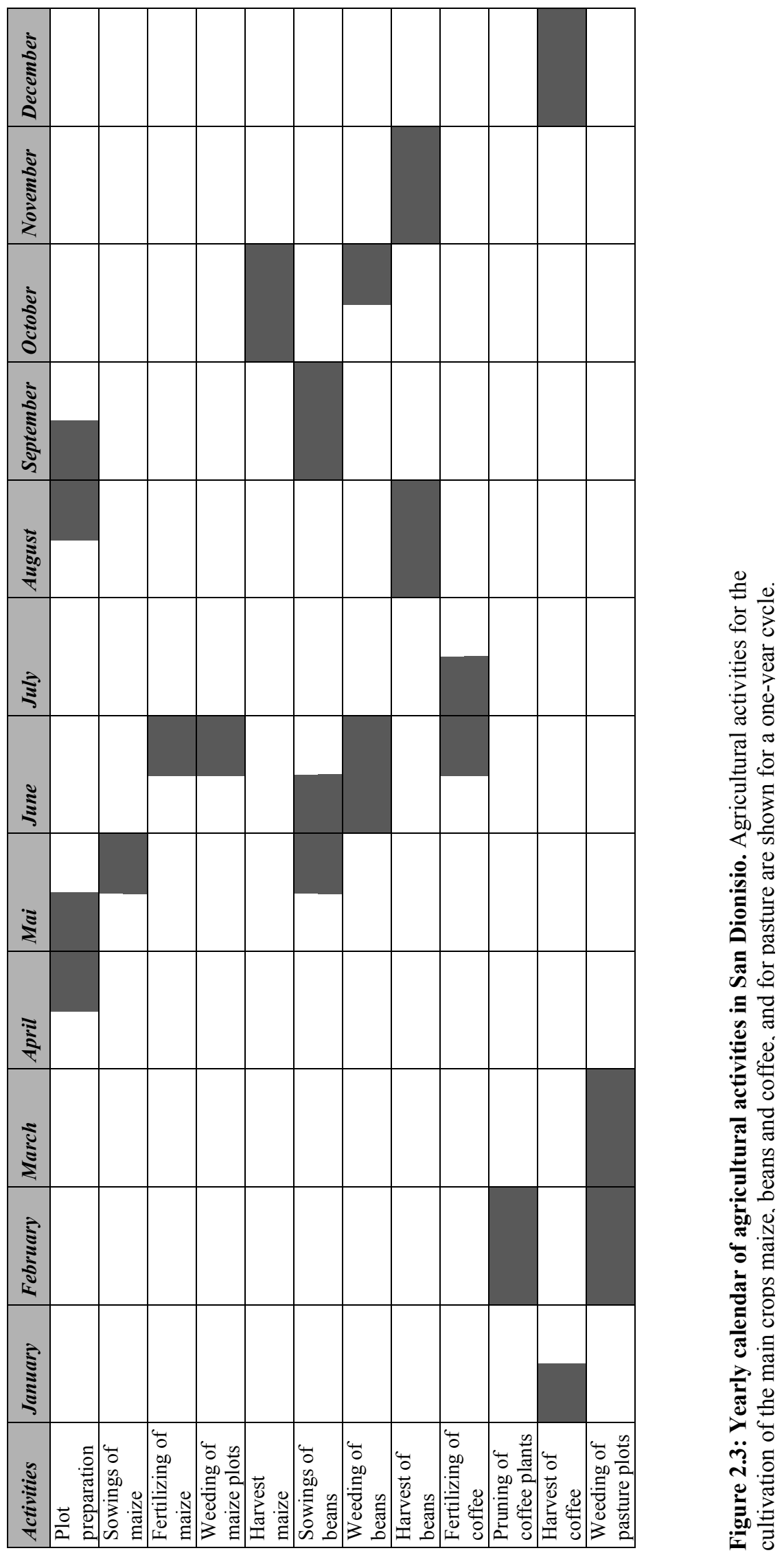


Yet, bean yield could be increased substantially if fertilizer was applied, as nitrogen is still a limiting factor. Fertilizing beans was found to be profitable, but risky, since the correct timing of fertilizer application is problematic (Gerbouin, P., personal communication).

The most popular mineral fertilizer is urea, followed by $15-15-15^{9}$ formula fertilizer. They are surface applied, which causes considerable nitrogen losses due to the climatic conditions. Although the use of inputs is popular, application rates are low due to the modest income of farmers and the difficulty to get credits. As a consequence, and as no alternative cultivation methods are used, yields tend to be low. On the other hand, potential nutrient resources from the own farm lie idle. Only rarely farmers make improved fallow and there is no composting or recycling of farm waste, manure or feces. As a researcher and extension worker with ample experience in the area said: "Rather than collecting the cow dung, poor farmers work for a few days in the fields of the rich and then buy the mineral fertilizer with their salary" (Orozco, P.P., personal communication). Furthermore, there is a cultural resistance against recycling human waste, as it is seen as something unclean, dirty and detrimental to human health. Thus, all these valuable nutrient sources are lost to the management system. Of course this nutrient management affects the natural resources, namely the soil and its fertility. Farmers complain that the soil is "getting tired", their way of explaining that soil nutrients are diminishing. This phenomenon is accelerated by erosion, favored by the hilly topography and the heavy rainfall on the bare ground at the beginning of the cropping season. With increasing population pressure farmers are forced to grow their staples on even steeper slopes, with the consequent increasing loss of fertile soil. In the future, farmers will face a further challenge with climatic change, as for Central America projections show more frequent extreme events which will cause estimate yield losses of at least 20 percent (IPCC, 2001).

This is especially critical in the case of beans, as they are not only the staple, but also the cash crop of the poor ${ }^{10}$. First of all, since there are no associated fertilizer costs, investment is relatively low compared to maize. Furthermore, after harvest, when

\footnotetext{
${ }^{9} 15-15-15$ fertilizer is composed of $15 \%$ nitrogen, $15 \%$ phosphorus and $15 \%$ potassium.

${ }^{10}$ Some studies consider beans to be the most important crop in terms of income (Davis et al., 2001).
} 
most farmers need money to pay back the loans, the price is much better for beans than for maize. Although the latter rises steadily during the dry period (Figure 2.4), beans still obtain a better price than maize during most time of the year. Furthermore, even if maize yields are more than double the bean yields, beans can be cultivated twice a year and the risk of a bad harvest is thus split.

As we have seen, productivity is low. Yet, decreasing prices paid for agricultural products do not stimulate farmers to seek higher productivity either. Furthermore, the marketing chain of agricultural goods causes a further drop in the revenue of farmers as it mostly includes intermediaries. Last but not least, especially on minor farms, food and money often gets scant before the first bean harvest. Thus, the months from May to July are difficult and many a farmer sells his harvest beforehand to the owners of the grocery stores in order to buy food, even though he gets an inferior price for his produce. Big farmers, on the other hand, store a lot of maize in their silos and wait until the price rises (Figure 2.4). They then pay the agricultural workers directly with maize and sell the rest for a good price on the market.

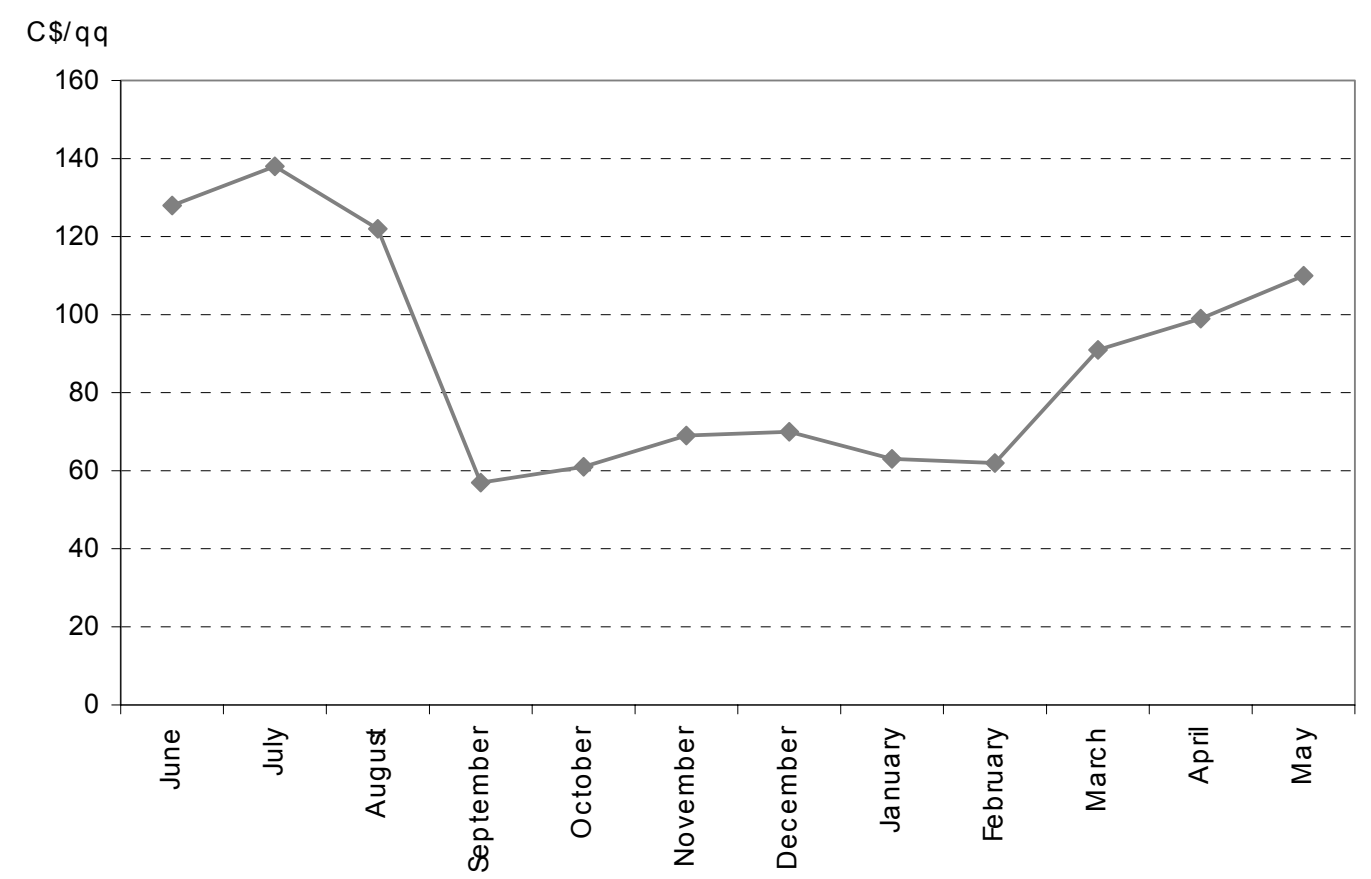

Figure 2.4: Price oscillations for maize in Nicaragua (1996/97). The price for maize oscillates considerably throughout the year. While during harvest season it is low, it rises strongly between April and July, when many farmers have to buy maize (Source: Agricultura \& Desarrollo, No. 36, 1998). 


\subsubsection{Animal and Livestock Production}

In the region of San Dionisio chicken, pigs, cattle, horses and mules are raised. Chicken are usually held in a free range system. Beside the maize grains they are fed with, usually inferior in quality, they pick a large variety of leaves, grasses and insects. Most of the people in San Dionisio hold chicken, as thus maize harvest wastes are capitalized. Yet, in most cases eggs and meat are not sold but contribute to a more equilibrated diet of the farmers' families. Only in December, when prices rise due to the traditional Christmas Eve dish "Stuffed Hen", farmers may sell part of their flock. A big problem for poultry production is the Exotic Newcastle Disease. This viral disease is probably one of the most infectious diseases of poultry in the world. A death rate of almost $100 \%$ can occur in unvaccinated flocks. Exotic Newcastle can infect and cause death even in vaccinated birds (United States Department of Agriculture, 2003). According to farmers in the study region, this disease causes great losses of poultry every year. It has to be mentioned though that most of them do not vaccinate their hens at all or not according to the recommendations. Pigs are also raised in an extensive way. The animals are roaming or tied to a post, according to the season. They are fed with household and harvest waste until the last two months before selling or home consumption, when they are fattened with maize.

\begin{tabular}{ll}
\hline Management & Percentage of Farmers \\
\hline Burn pasture every year & 40 \\
Burn pasture every 3-5 years & $25-30$ \\
Never burn pasture & 15 \\
Pastures burnt by accident & $15-20$ \\
\hline
\end{tabular}

Table 2.1: Pasture burning practices in San Dionisio, Matagalpa. Pastures are burnt before the rainy season by most farmers of the area at least once every 3-5 years (Source: Benziger E., personal communication)

The livestock production, with dual purpose milk and meat production, is extensive. Mostly the only fodder resource is natural pasture, which leads to fodder shortage and severe bovine malnutrition during the dry season. Contemporaneously water scarcity 
hampers livestock farming: In 1998 Hurricane "Mitch" washed away the big trees which served as shade protection of the main river. As a consequence the stream runs dry during the months it does not rain. These factors cause a low fertility rate (ca. $50 \%$ ) and a low milk yield of the cows. Before the onset of the rains in May most farmers burn their pastures, at least once every 3-5 years (Table 2.1).

\subsubsection{Coffee and Forest}

Coffee is the main cash crop of the region. It is mostly produced above 800 m.a.s.l. in the traditional agro forestry system under shade trees (Figure 2.5). The three common varieties grown in the area are Arabica (Coffea arabica var. Typica L.), Caturra (Coffea arabica var. Caturra) and Burbón (Coffea arabica var. Bourbón). Often different varieties are grown on the same plot. Generally plantations are old, the plants are not systematically renovated, and not very well maintained. Most farmers, for instance, do not prune the coffee plants yearly as recommended by extension workers.

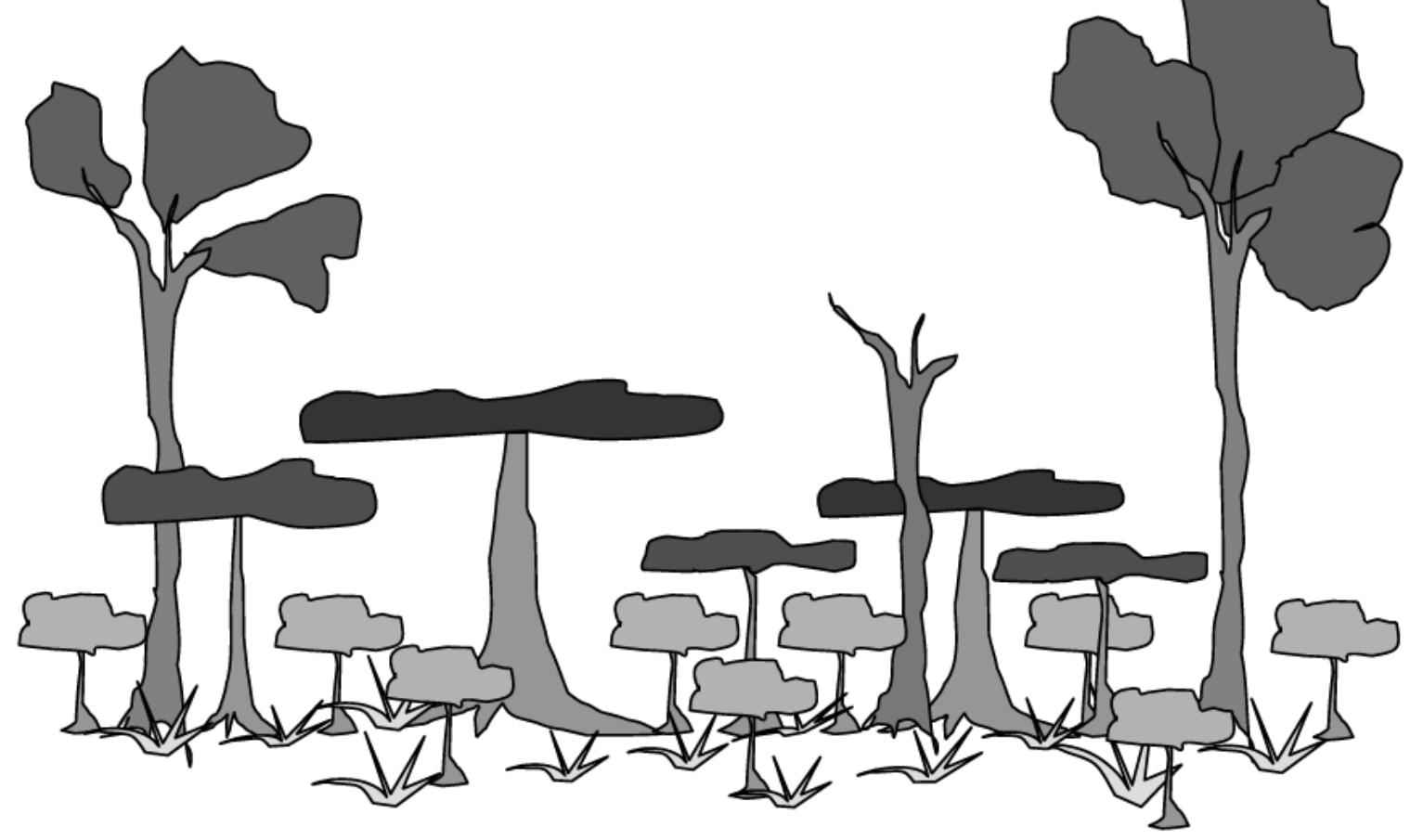

Figure 2.5: Traditional coffee growing under a variety of multi-story shade trees. In Central America coffee bushes are traditionally grown in a thinned out forest. Biodiversity in these systems is high. 
Another factor having significant effects on coffee yields is the shade tree cover, which has to be steadily regulated (Soto-Pinto et al., 2000). Furthermore, after the dramatic drop of coffee prices on the world market in 2000/2001, none of the farmers fertilizes the coffee plants anymore. For all these reasons yields tend to be low. One privately owned coffee mill (beneficio) exists in the town of San Dionisio. There, the region's coffee producers sell most of their produce. The husk is seldom used as fertilizer and usually thrown away. The shade trees of the coffee plots have yet another function: The main energy source predominantly used for cooking is firewood from local supply. It is taken from hedges and from coffee and natural forests. As not everybody owns a forest plot, wood is often taken from alien land. Although the forest is privately owned, firewood logging is hard to control.

\subsubsection{Choice of Community}

Susulí, one of the 15 communities of the municipality of San Dionisio, was chosen for a deeper analysis and data collection. In a participative analysis of the region of San Dionisio this community was shown to be average for the indicators forests, soil quality, crops and crop variety, domestic animals, and pastures. This means that for none of these characteristics conditions were unfavorable. Moreover, lack of water does not limit agricultural activities (Espinoza and Vernooy, 1998). Susulí is also characterized by a high population density and a high percentage of landless farmers. Thus, it is an interesting study object, as future problems of other communities are already visible there. Although in many areas the current population density is still low, this may soon change, as demographic projections indicate an absolute increase in rural populations in areas like Central America (Dixon et al., 2001). In Nicaragua, population growth in rural areas is still as high as $4.4 \%$ (INEC, 2003).

\subsection{Material Flux Analysis}

In the 1990's the methodology of Material Flux Analysis (MFA), which examines the metabolism of anthropogenic systems e.g. a region or industry, was developed (Baccini and Bader, 1996; Baccini and Brunner, 1991). It assesses the flux of different 
materials through a defined space, within a certain time period. The first step includes a system analysis, consisting of the definition of a system border, processes, goods (commodities) and indicators. Then, the commodity fluxes and their indicator element concentration or energy content are assessed. In a next step, the element or energy fluxes of the whole system according to the physical laws of Conservation of Mass and Energy are calculated. These are schematically presented and the results are interpreted. One crucial aspect is the identification of important sources and sinks of a material, which allows the prediction of environmental problems. MFA is moreover used as a tool to show possible strategies for the sustainable management of natural resources.

Mostly, MFA studies of the regional metabolism have been carried out in urban regions of industrialized countries (Hug, 2002; Faist, 2001; Redle, 1999, Müller, 1998; Real, 1998). Much of the data used was taken from official statistics. Despite big gaps in data availability, MFA could be adapted to the conditions of urban areas in transition countries by measuring many of the missing data (Binder, 1996). Von Steiger and Baccini (1990) applied MFA to rural areas. They analyzed the farming systems of a region in the Swiss Lowland, based on data taken from the diaries of selected farmers and from the bookkeeping of agricultural cooperative societies. They showed that Swiss agricultural soils served as a sink for phosphorus and heavy metals. With Metaland, a typical urban area, Baccini and Brunner (1991) first introduced the tool of a fictive model region for the investigation of the regional metabolism. The advantage of this approach was the validity of the results for European urban areas in general. To create Metaland, data of existing urban regions were compared and the main characteristics were attributed to the model region. Nevertheless, none of these approaches is suitable for developing countries. Existing data is sparse, money lacks for measurements, and illiteracy of farmers is widespread. A new approach was thus chosen with an original field study (see section 2.6.1). Almost all of the data was collected in a field survey or taken from literature. As the selected region shows similarities to the Mesoamerican farming system in its main characteristics, it can serve as a role model for similar Central American agricultural regions. 


\subsection{Stratification of Farmers}

In order to understand an agricultural region as a whole, the farming management systems it comprises have to be analyzed and compared and the vulnerability of farmers' groups have to be detected. The latter is especially important in areas like Central America, where climatic challenges like hurricanes and droughts are frequent. A farmer family's resilience to shock depends on various factors such as assets, possession and management system (Morris et al., 2002; Holt-Giménez, 2002). Although the very poor often do not have much to loose in absolute terms, a small amount of damage may be disastrous for families with few assets to start with. Thus, it has been shown that in the 1990s poverty was the most widespread cause of food insecurity ${ }^{11}$ (Smith et al, 2000). This has to be taken into account when investigating farming systems and their resilience, for instance by a stratification of farmers. The approach chosen in this study was based on two assumptions:

1) The farming systems as defined by FAO (FAO, 1995) are tightly linked to socioeconomic factors

2) The latter are reflected mainly by land holdings (Davis et al., 2001).

Thus, farmers were split into four groups, namely landless, smallholders, medium farmers and big farmers according to land tenure (Table 2.2). The definition of the strata was based on previous studies carried out in the region (FAO, 1995; NitlapánUCA, 1995). It was adapted to the purpose of this study by adding the stratum of the landless, which in Susulí accounts for roughly half of the population (Leemann, forthcoming). Nevertheless, it has to be borne in mind that on a global scale all the farmers' strata chosen are smallholders. When all data was collected, MFAs were calculated for each stratum and then extrapolated proportionally to a regional MFA in a bottom-up approach (Figure 2.6). The MFAs were set up with average figures. Yet, if less than half of the farmers of a given stratum were dedicated to a certain activity (e.g. crop, animal raising), it was not included in the MFA. Land used for such activities was proportionally distributed among the others. 


\begin{tabular}{|c|c|c|c|c|c|c|c|}
\hline Stratum & $\begin{array}{l}\text { Land holding } \\
\text { [ha] }\end{array}$ & $\begin{array}{l}\text { Average Land } \\
\text { Managed [ha] }\end{array}$ & Crops [\%] & & \multicolumn{2}{|l|}{ Animals [\#] } & $\begin{array}{l}\text { Percentage } \\
\text { of families }^{12}\end{array}$ \\
\hline Landless & $0<\mathrm{X} \leq 0.35$ & 0.7 & Staples & 100 & Chicken & 3 & 50 \\
\hline Small & $0.35<\mathrm{X} \leq 3.5$ & 2 & $\begin{array}{l}\text { Staples } \\
\text { Coffee }\end{array}$ & $\begin{array}{l}88 \\
12\end{array}$ & Chicken & 9 & 30 \\
\hline Medium & $3.5<\mathrm{X}<10.5$ & 5.6 & $\begin{array}{l}\text { Staples } \\
\text { Coffee \& Forest } \\
\text { Pasture }\end{array}$ & $\begin{array}{l}63 \\
16 \\
21\end{array}$ & $\begin{array}{l}\text { Chicken } \\
\text { Pigs } \\
\text { Horses }\end{array}$ & $\begin{array}{r}12 \\
1 \\
1\end{array}$ & 15 \\
\hline Big & $10.5 \leq$ & 19.5 & $\begin{array}{l}\text { Staples } \\
\text { Coffee \& Forest } \\
\text { Pasture }\end{array}$ & $\begin{array}{l}27 \\
22 \\
51\end{array}$ & $\begin{array}{l}\text { Chicken } \\
\text { Pigs } \\
\text { Horses } \\
\text { Cows }\end{array}$ & $\begin{array}{r}14 \\
2 \\
2 \\
7\end{array}$ & 5 \\
\hline
\end{tabular}

Table 2.2: Farmers' strata in Susulí, San Dionisio, Matagalpa: The characteristics of the average farms of the four strata landless, small, medium and big farmers are shown. The difference between land holding and the land managed is land rented to other farmers. Sharecropped land is contained in the figures of landlords and tenants. Staples: Maize and beans.

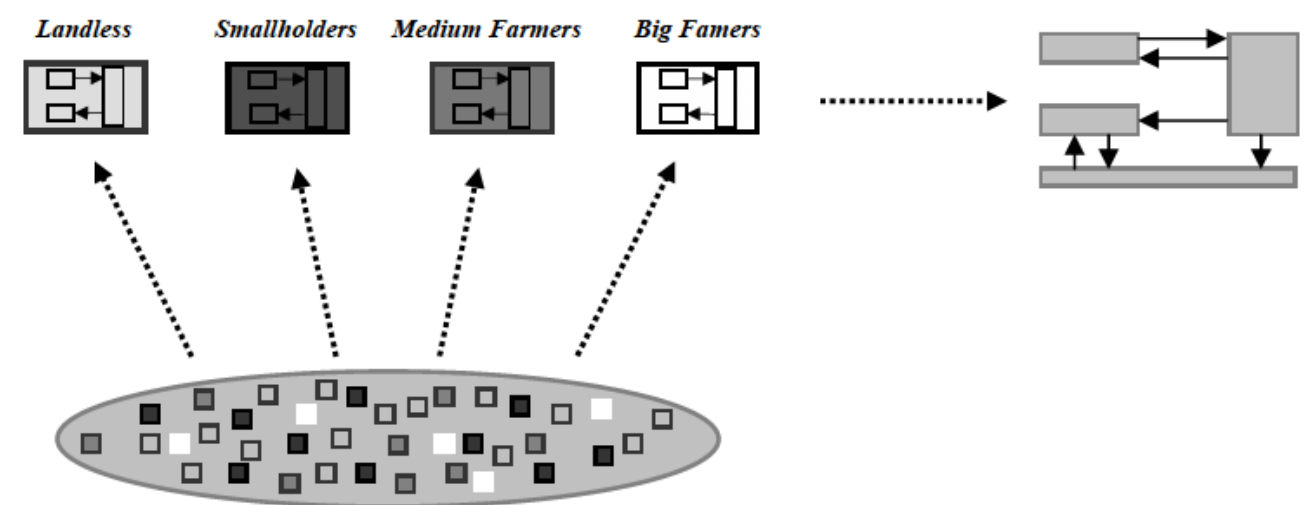

Figure 2.6: Bottom-up approach in Material Flux Analysis: Fifteen farmers of each of the four strata landless, smallholders, medium farmers and big farmers were sampled and interviewed. MFA were set up for prototype farms of the four strata. Results were extrapolated to a regional level and a regional MFA was elaborated.

\footnotetext{
${ }^{11}$ The poor also have inadequate access to information and appropriate technology, public goods and infrastructure, as well as a lack of regional economic development (Birdsall and Londoño, cited in Davis et al., 2001).

${ }^{12}$ Leemann E., forthcoming.
} 
Furthermore, the land managed by the different farmers' strata and not the land owned was chosen. The land managed by an average farm of a stratum is considered to be the land for which management and certain other decisions (e.g. crop choice) can be taken, and which is often not equal to land holdings. This means that land rented to others is not included, while sharecropped land is assigned to the landowner and the worker. The reason this setup was chosen is the relevance of the access to land. While the security of this access is equally important, it cannot be assessed within the scope of this study. Nevertheless, it has to be borne in mind that the access to alien land is highly insecure, especially if not obtained through family bonds. Thus, landless farmers may get land one year, the following year they may not. This makes them depend strongly on landowners. Peasants are in turn often subject to obligations with patrons, like helping them during work peaks. These factors can restrain the landless' choices: they may not be able to cultivate well their rented plot or accept a temporary but better paid job.

On average, the chosen strata were found to differ considerably in the amount of land managed, land use and animal holding (Table 2.2).

The landless farmer has access to an average of 0.7 ha of land for both cropping seasons. He only grows staples, mainly beans (Table 2.2). Nevertheless, it should be borne in mind that while some landless farmers have access to a bigger plot than the average, others do not have any land they can farm. The latter phenomenon is very common among single women with small children. In the best case they can rent land, but they will not find a landlord for sharecropping, as their working force is considered to be minor. Therefore, these landless peasants are at a disadvantage, because they have to pay a fixed price for the land independent on the yield. Thus, they pay the same rent for a good or a bad year, and even for a total crop loss. On the other hand, in a good year they keep the whole surplus. A further problem when renting is the timing of payment. Usually the money has to be paid in advance, at a time when means are scarce.

The small farmer cultivates mainly staples and some coffee on an average of 2 ha. A considerable part of the land is sharecropped, an indicator that small farmers are short of workforce. It is also suggested by the smaller average family size of 5.3 (vs. slightly more than 6) of the small farmers. This can be explained with the 
considerable number of young families with babies or aged couples in the sample of small farmers. Most landless and small farmers own some chicken only.

The average land area a medium farmer manages is 5.6 ha. More than half of it is staples, mainly beans, while the rest consists of the perennial crops coffee, forest and pasture. The medium farmer sharecrops part of his land, but also employs daylaborers for work peaks. Beside chicken he owns a pig and a horse.

A total of 19.5 ha are managed by the big farmer. Thereof roughly a fourth is staples, a fifth is dedicated to coffee growing and forest, while half of it is used as pasture. The big farmer lends or rents part of his land to landless peasants. While many big farmers engage permanent workers, all of them employ additionally paid workforce during seasonal peaks. On big farms the average animal stock consists of chicken, two pigs, two horses, four cows and several calves.

\subsection{System Analysis for the Stationary Model}

\subsubsection{System Borders}

The functional system in this study includes the agricultural production processes and the farmer's family (farm level) or the local population (regional level) as the primary consumers. Thus, food and energy self-sufficiency and vice versa the dependency on the Hinterland can be assessed. This system choice also allows the integration of population dynamics into the model. This is a particularly important factor if we keep in mind its high growth rate of 4.4\% (INEC, 2003). The geographical system's boundaries are defined as follows: As the sampled farmers were all inhabitants of the community of Susulí, the system covers in fact all the land managed by people living in Susulí. Thus, land in the community managed by external farmers is not included in the system, while land outside of Susulí managed by a local is. Nevertheless, roughly it can be assumed that the system's limits correspond to those of the agriculturally managed land of the community of Susulí (Figure 2.8). Hence, no man's land like roads, grass strips along the roads, rivers etc. are not included in the model. Neither 
are the houses and the patios (courts), where in many homes some fruits or vegetables are produced. The time span investigated is one year.

\subsubsection{Indicators, Assessment Criteria and their Mathematical Description}

The following indicators were chosen for this study: Nitrogen, the degree of self sufficiency (DSS) for energy and for staples and the coverage of the canasta básica ("the basket of basic needs").

Nitrogen is the limiting factor in most agro ecological systems. As a matter of fact, fertilizer essays have shown that this is the case in our study region (Orozco, P.P., personal communication). Due to economic constraints farmers in developing countries cannot import mineral fertilizer ad libitum. As a result, and due to permanent cropping, nutrients are mined from the plots. Studies in Africa have shown that nutrient mining in rural areas can be substantial, which on the long run is detrimental to productivity (Elias et al, 1998; van den Bosch et al, 1998; Folmer et al, 1998). Thus, for Uganda nitrogen losses of between 40 (beans) and 104 (maize) $\mathrm{kg} / \mathrm{ha}$ *a have been assessed, while pastures showed a positive $\mathrm{N}$ balance of roughly $20 \mathrm{~kg} / \mathrm{ha} *_{\mathrm{a}}$ (Wortmann and Kaizzi, 1998). On a supranational scale, figures for nitrogen mining lie between $0 \mathrm{~kg} \mathrm{~N} / \mathrm{ha}$ *a (Botswana) and $68 \mathrm{~kg} \mathrm{~N} / \mathrm{ha}$ *a (Malawi) for diverse African countries, with the remaining of them accounting for $30-50 \mathrm{~kg} \mathrm{~N} / \mathrm{ha}^{*} \mathrm{a}$ mined (Stoorvogel et al., 1993, cited in Nandwa and Bekunda, 1998). Another, economic, approach of De Jager et al. (2001) showed that in the Machakos District in Kenya $60-80 \%$ of the farm-income is based upon nutrient mining. In this study, the nitrogen mined is defined as follows for each process and for the system as a whole:

Nitrogen $_{\text {mined }}=$ Nitrogen $_{\text {in }}-$ Nitrogen $_{\text {out }}$ if Nitrogen $_{\text {out }}>$ Nitrogen $_{\text {in }}$

Another basic factor for rural survival and development is energy. In rural developing areas most of it is used for cooking. Poor people depend on staple foods like rice, corn and beans. These are often inedible when energy is lacking to prepare them for ingestion. In cold climates, it is also essential for heating the dwellings. Thus, energy 
needed to satisfy the basic human needs of food (cooking), warmth and light are indispensable to maintain any anthropogenic system. Due to their importance, traditional energy sources, mainly firewood, have to be managed at a sustainable rate. Although firewood is a renewable energy source, the rate of extraction is bigger than the forest growth rate. As early as in the 1970s, the danger of a "wood fuel crisis" was acknowledged (WEC/FAO, 1999), but the topic of energy use in rural areas has been neglected afterwards.

Thus, as a second indicator the degree of self-sufficiency of energy $\left(\mathrm{DSS}_{\mathrm{E}}\right)$ has been chosen. For a system in steady state ${ }^{13}$ it is defined as follows:

$$
D S S_{E}=\frac{P_{F W}}{C_{F W}}
$$

$D S S_{E}$ : Degree of self-sufficiency for energy (firewood)

$P_{F W}$ : Production of firewood on own land $[\mathrm{kg}$ wood/farm*a]

$C_{F W}$ : Consumption of firewood $[\mathrm{kg}$ wood $/$ farm*a $]$

The third indicator, the degree of self-sufficiency (DSS) for staples, suggests a way of assessing long-term food security. In this study it is for the first time defined as follows: The concept of the DSS for staples as it is used here is not limited to nutritional needs of the farmers' families. It assesses the survival of the staple system as a whole and thus includes fodder, wages and fertilizer costs in grain equivalents. Only if a farming system is able to provide all this, it can survive on a medium term without undergoing severe changes. Nevertheless, to understand its functioning, it is important to compare the different crops, as e.g. maize is primarily a crop for autoconsumption, while beans are grown for the market. Thus, in this study we will look at the DSS of maize and beans separately.

The DSS used in this thesis is defined as follows for maize: 
$D S S_{M}=\frac{A_{M} H_{M}}{C_{H M}+C_{C}+C_{P}+S_{M}+F_{\text {costs }}+W_{M}+W_{M S C}}$

$D S S_{M}$ : Degree of self-sufficiency for maize (for the farming system)

$A_{M}$ : Area of maize production [ha/farm]

$H_{M}$ : Maize Harvest $\left[\mathrm{kg} / \mathrm{ha}{ }^{*} \mathrm{a}\right]$

$C_{H M}$ : Maize consumption humans $[\mathrm{kg} /$ farm*a]

$C_{C}$ : Maize consumption chicken $[\mathrm{kg} / \mathrm{farm} * \mathrm{a}]$

$C_{P}$ : Maize consumption pigs $[\mathrm{kg} / \mathrm{farm} * \mathrm{a}]$

$S_{M}$ : Seeds $[\mathrm{kg} /$ farm*a]

$F_{\text {Costs: }}$ : Fertilizer costs for maize in maize equivalents $[\mathrm{kg} /$ farm*a]

$W_{M}$ : Wages for outside workforce for maize production in maize equivalents $[\mathrm{kg} / \mathrm{farm} * \mathrm{a}]$

$W_{M S C}:$ Maize paid to maize sharecroppers $[\mathrm{kg} /$ farm*a]

The DSS for beans is defined as:

$$
D S S_{B}=\frac{A_{B} H_{B}}{C_{H B}+S_{B}+W_{B}+W_{B S C}}
$$

$D S S_{B}$ : Degree of self-sufficiency for beans (for the farming system)

$A_{B}$ : Area of bean production $[$ ha/farm]

$H_{B}$ : Bean Harvest $\left[\mathrm{kg} / \mathrm{ha} *_{\mathrm{a}}\right]$

$C_{H B}$ : Bean consumption humans $[\mathrm{kg} /$ farm*a]

$S_{B}$ : Seeds $[\mathrm{kg} /$ farm*a]

$W_{B}$ : Wages for outside workforce for bean production in bean equivalents [kg/farm*a]

$W_{B S C}$ : Beans paid to bean sharecroppers $[\mathrm{kg} /$ farm*a]

The DSS is an indicator for economic stability of staple production. Furthermore, as all farmers' strata grow staples it is a good indicator for a comparison between them. It has to be borne in mind though, that farmers who own coffee and livestock have a

\footnotetext{
${ }^{13}$ Only the wood that grows in a certain period is extracted in the same period.
} 
big advantage over those which do not. They can diversify their income and - as a result - show a better potential to build up capital for investment. They are also more resistant to shocks (e.g. bad harvest, sudden price falls on the market).

As the goal of development is to ensure the livelihood of farmers, analysis cannot be limited to basic nutritional needs. Farmers have other necessities such as a balanced nutrition, energy, health and education. Thus, a further indicator was introduced to analyze to what extent the farming systems can cover the families' basic ${ }^{14}$ (or minimum) needs (Table 2.3). It is defined as follows:

$C B_{\text {covered }}[\%]=\frac{\text { Income }_{\text {farming }}}{\text { Cost }_{\text {basicneeds }}} 100 \%$

$\mathrm{CB}_{\text {covered: }}$ Part of the basic consumer basket (canasta básica), which can be covered with the income from agricultural activities.

Farmers have the following income sources: Staple, animal, milk and coffee sale, work on other farms and non-farm income. Although other studies have shown that in the Nicaraguan Pacific zone the latter makes up for a considerable share of total family income (Corral and Reardon, 2001), it was not considered in this analysis. On one hand, reliable data is lacking and on the other hand, the goal of the overall analysis in this study was the farming systems in the strict sense (e.g. income only from farming).

\footnotetext{
${ }^{14}$ These needs are really basic if we consider that, beside a more or less balanced nutrition, only one top, one pair of pants and one pair of shoes - all of minor quality - can be bought. Furthermore, solely medicine for common illnesses can be paid for. Last but not least, only school fees, but not the school material have been considered.
} 


\begin{tabular}{lll}
\hline Item & Canasta básica & $\begin{array}{l}\text { Canasta } \\
\text { mínima }\end{array}$ \\
\hline Maize & $\sqrt{ }$ & $\sqrt{ }$ \\
Beans & $\sqrt{ }$ & $\sqrt{ }$ \\
Sugar & $\sqrt{ }$ & $\sqrt{ }$ \\
Rice & $\sqrt{ }$ & $\sqrt{ }$ \\
Coffee & $\sqrt{ }$ & $\sqrt{ }$ \\
Salt & $\sqrt{ }$ & $\sqrt{ }$ \\
Lime & $\sqrt{ }$ & $\sqrt{ }$ \\
Oil & $\sqrt{ }$ & $\sqrt{ }$ \\
Cheese & $\sqrt{ }$ & - \\
Meat & $\sqrt{ }$ & - \\
Chicken & $\sqrt{ }$ & - \\
Eggs & $\sqrt{ }$ & - \\
Pop & $\sqrt{ }$ & - \\
Fruit & $\sqrt{ }$ & - \\
Vegetables & $\sqrt{ }$ & - \\
Onion/Garlic/Pepper & $\sqrt{ }$ & - \\
Soap (personal hygiene.) & $\sqrt{ }$ & $\sqrt{ }$ \\
Soap (clothes) & $\sqrt{ }$ & $\sqrt{ }$ \\
Soap (dish) & $\sqrt{ }$ & - \\
Toilet paper & $\sqrt{ }$ & $\sqrt{ }$ \\
Shampoo & $\sqrt{ }$ & - \\
Health & $\sqrt{ }$ & - \\
Education & $\sqrt{ }$ & - \\
Clothes & $\sqrt{ }$ & - \\
\hline
\end{tabular}

Table 2.3: Composition of the Canasta Básica and the Canasta Mínima. Energy was not included in the two baskets, as at the moment barely anybody outside of the town of San Dionisio pays for access to firewood. 


\subsubsection{0-System and Mathematical Model}

The chosen system, shown in Figure 2.9, can be applied at farm and regional level. It consists of four internal and three external processes. The former are food production, animal production, coffee \& forest on one hand, and farmer's household on the other hand. The first three processes describe the agricultural land use options. They comprise the plants, the animals and the soil on which the agricultural activities take place. Thus, holding of cattle and horses leads to the incorporation of the pasture land in the process, while to pigs and poultry, which usually live in backyards and at the edge of the roads, no land is allocated. The process farmer's household aggregates the family, their food and energy consumption, and food processing.

There are 22 commodity fluxes:

- food autoconsumption of the farmers' households

- food purchased from outside the region (e.g. rice and sugar)

- harvest sold standing for the exported surplus of maize and beans produced in the region

- mineral fertilizer for food and coffee production

- waste gases emitted from the processes food production (nitrogen losses caused by the burning of plant residues and by the volatilization loss of fertilizer), animal production (volatilization of nitrogen in urine and dung, pasture burning) and the farmers' households (firewood burning)

- nitrogen deposition on the plots belonging to the processes food production, animal production and coffee \& forest and the flux biological nitrogen fixation into the process food production originating from the cultivation of beans

- fodder, the maize consumed by chicken and pigs

- animal products consumed by the households of the region (mainly eggs and chicken meat, some milk for the production of soft cheese)

- animals bought

- animals and animal products sold 
- coffee produced and sold (parchment coffee). The autoconsumption of coffee is small and therefore neglected.

- husk (coffee husk) which is thrown away and therefore lost to the system.

- manure from chicken and pigs dropped anywhere around the house and on the street and therefore lost to the productive system.

- firewood from the own farm used by the households for cooking

- firewood from the Hinterland

- leftovers from meals and whey

- household waste containing mainly human feces and ash.

As the impact of land management on erosion and leaching under the given circumstances was difficult to assess, these two fluxes were not included in the system. Nevertheless, its possible effects and its range will be discussed.

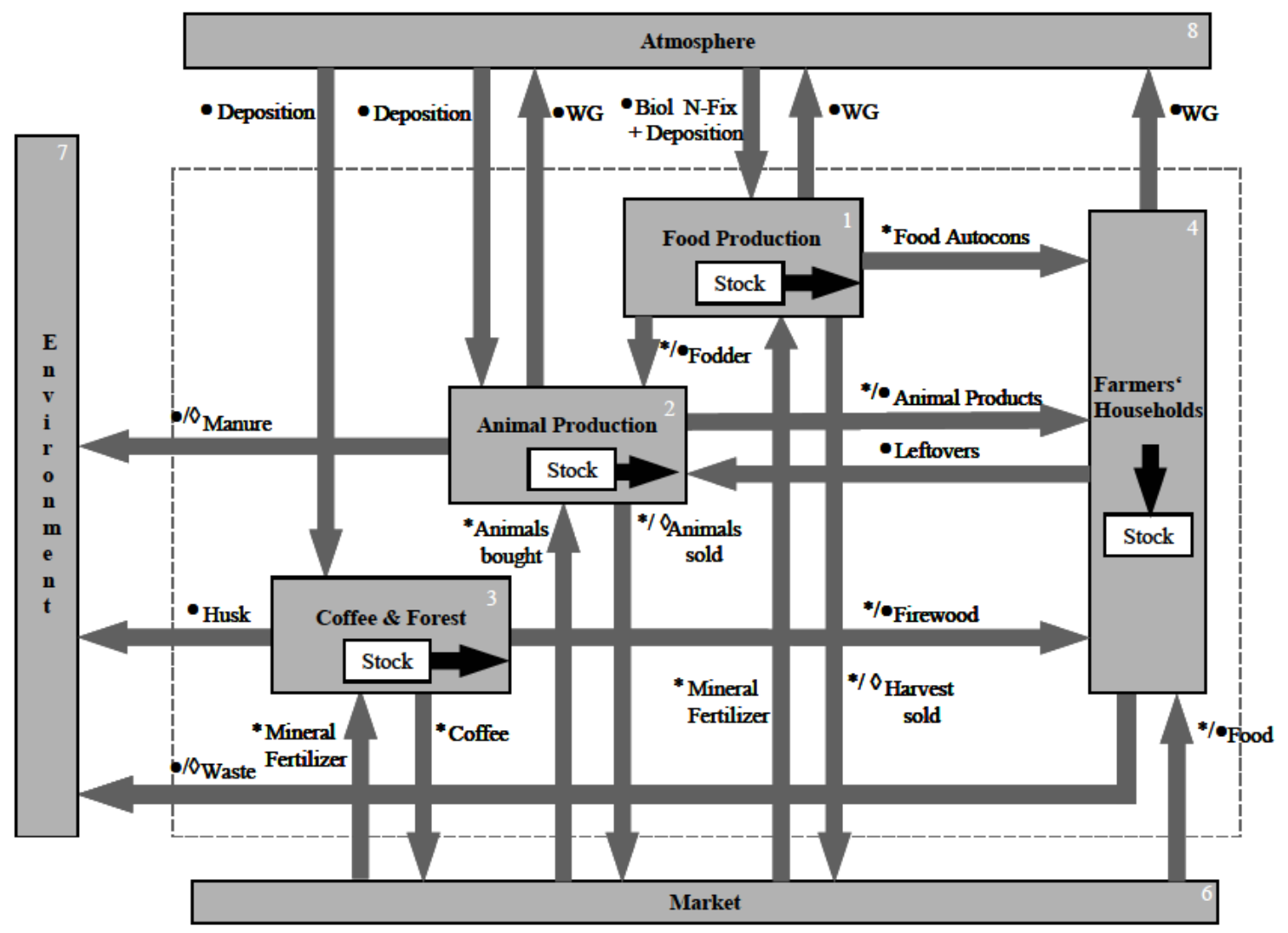

Figure 2.9: System Analysis and data source: Data sources:* interviews with farmers, $\bullet$ literature, $\diamond$ own calculations and considerations. The black fluxes are calculated from the system (see section 2.5.3. and 2.6). WG= Waste Gases 
The mathematical model describing the system (Appendix A) was elaborated on farm level. The model comprises 30 variables and 30 equations, of which four - the change of the stocks food production, animal production, coffee \& forest and farmer's household - are balance equations. For the regional analysis the same model can be used with some adaptations. Thus, one has to consider that the wages paid to workers in grain and the contribution to sharecropping remains in the region and is now part of the flux food autoconsumption and not of harvest sold.

\subsection{Data}

\subsubsection{Source and Collection}

As we know of pioneer MFA studies in transition countries (Binder, 1996), there is few or no regional statistical data to be found. Thus, the established way of assessing the fluxes of an MFA model could not be followed and new approaches had to be found. The data of this study derives from an original field study, mainly based on interviews with farmers. The rest of the data is mostly taken from interviews with key persons and from literature. The first contact with farmers of Susulí was established in fall 2000. Nine farmers, three from each of the strata small, medium and large, were chosen as key persons in order to deepen the knowledge about the system. They were visited regularly and interviewed about farm and plot management. Visiting plots was also part of the program. After data processing in Switzerland, a second field phase followed in fall 2001. It was based on a census of the community elaborated by Leemann (forthcoming), in which all households ${ }^{15}$ and, among other, their land holding was registered. The boundaries of the community had been established in a baseline study ("Sustainable Development Analysis") before (Leemann, forthcoming). For the present thesis, a randomized list of farmers was elaborated for each stratum separately. The first fifteen farmers on the list were visited and interviewed in semistructured interviews. If there were problems (physical absence, mental disorders,

\footnotetext{
${ }^{15}$ The definition of household in this census was based on the self-assessment of its members according to the following criteria: If its members had the impression that they had to look for their own income and survival, although they were living with relatives, they were considered to be a separate household.
} 
refusal), the next farmer on the list was chosen. There were also cases of landless families, which in effect managed the land of their wealthy parents or worked fulltime in the "Zona Franca". In both cases, they were not considered for calculating the average farm of the stratum; nevertheless, they were included in the regional model as consumers. As in some cases existing information was not accurate enough, or people had bought or sold land, in the end the author interviewed 14 landless, 13 small, 16 medium and 17 big farmers. Furthermore, although the goal of the study was to do research on people whose main income comes from agriculture, this proved to be difficult in the case of the big farmers. Most of them run their own grocery store and thus they had to be included despite of this fact. In the semi-structured interviews the following data was gathered: Farm management, fertilizer and pesticide use, yields, storage and sale of grain, autoconsumption, human nutrition, fodder, animal holding, and firewood source. On one hand, the information covered the ongoing year (2001) and partially the year before. On the other hand, the interviewer tried to get a better understanding of changes over time, means (e.g. average harvest in an average, good and a bad year) and limits. For some figures difficulties emerged. Thus, in some cases the allocation of land to a certain owner proved to be complicated. Many were for instance formerly still owned by the parent, but as a matter of fact the children were taking the relevant management decisions. Furthermore, some farmers wanted to give the impression to be especially successful and exaggerated obviously when providing yield information. Other figures like daily maize and bean consumption are hard to estimate because farmers' wives, when preparing the meals, just take what is needed from the stock. Thus they never weigh their staple consumption and have difficulties estimating. Nevertheless, as they have to buy rice and sugar at the store, they usually know these consumption figures quite well. But again, many people were ashamed to talk about their poverty and only from calculations and other data could their actual food consumption be estimated. Last but not least, yield when not sold is mostly estimated by measures of capacity ("Hohlmass"). Thus, farmers give approximate figures of their harvest. Yet, figures given could be compared with one another and cross-checked with data obtained from key persons (e.g. extension workers). With this information, complemented with data from literature, average farms for each stratum were computed and extrapolated to a regional material flux model (Figure 2.6). We 
have therefore to bear in mind that average maize and bean yields, input use, animal holding and even family size differ across the four strata.

\subsubsection{Quality}

Due to the sources of information and the many assumptions, we have to presume a relatively big uncertainty margin of up to $50 \%$ for certain parameters. Nevertheless, most of them do not have a big influence on the target values according to the sensitivity analysis (see sections 2.7 and 3.3). The uncertainty margins of maize and bean harvests, two key parameters in the systems, differ considerably. While for regular bean harvests it amounts for all strata to $10-15 \%$, for maize it is higher and differs among strata. The biggest variation shows the stratum of small farmers with roughly $40 \%$. This can be explained by the fact that some smallholders are young upstriving persons with a relatively well-off family background, while others are elderly and poor. The former use fertilizer and may have access to workforce and material support from their families and can thus count with quite good maize harvests. The latter often farm with few chemical inputs, no mineral fertilizer and no support and thus harvest poor maize yields. Another uncertainty consists of the figures obtained for firewood consumption, growth of Central American forests and the local forest area. For the former two, figures from El Salvador have been taken and some assumptions have been made (Rivas, 2000). The latter has been compared to other studies about the region (Leemann, forthcoming). The uncertainty margins are estimated to be $-25 \%,+35 \%$ and $+/-25 \%$ respectively. 


\subsection{Sensitivity Analysis and Uncertainty Propagation}

A sensitivity analysis was carried out in order to estimate the impact of small parameter variations on the assessment criteria. In this case, the sensitivity of the parameters on nitrogen mining and on the three DSS was determined. The sensitivity analysis gives raise to a better understanding of the system as a whole. Moreover, it is an important instrument to estimate the effect of parameter inaccuracy and the weight of individual parameters upon the results. Its performance is also an important precondition for the development of scenarios.

The relative sensitivity per $100 \%$ is calculated as follows:

rel.sensitivity $=\frac{p_{j} \Delta X_{i}\left(\Delta p_{j}\right)}{X_{i} \Delta p_{j}} 100 \%$

$p_{j}$ : Parameter $\mathrm{j}$

$X_{i}:$ Variable i

Thus, the variation of parameter $\mathrm{p}$ may provoke three types of responses of the variable:

a) Low sensitivity: The variable changes less than $100 \%$ to the corresponding variation of the parameter.

b) Proportional sensitivity: The variable changes 100\% when the parameter is varied $100 \%$.

c) High sensitivity: The variable changes more than $100 \%$ to a parameter variation of $100 \%$.

Results of the sensitivity analysis are presented in section 3.3.

A proper error propagation analysis could not be carried out for this study. The uncertainties of the single parameters mostly had to be estimated, as no reliable data for comparison exists. Yet, certain boundary conditions helped to estimate the error margin of the results (see section 2.6.2). 


\subsection{Main Assumptions}

For setting up the quasi-stationary model some important assumptions had to be made. The most relevant ones are listed below (Table 2.4), while all of them are listed in the appendix (Appendix B).

\begin{tabular}{ll}
\hline Process & Assumptions \\
\hline Food production (1) & An average yield for maize and bean harvest for each stratum \\
& All farmers burn the crop residues \\
& Credits and debts have been neglected \\
& Local bean cultivar has a low N-fixing potential \\
& There is a dynamic equilibrium for the animal stocks \\
& No pigs and horses are bred in the region \\
Animal production (2) & Cattle and horses only consume pasture \\
& Pastures are burnt by a part of the farmers (Table 2.1) \\
& No fertilizer applied to coffee plots \\
An average yield for low-input coffee & Consumption of basic foodstuffs (maize, beans, rice, sugar) is equal \\
Coffee \& Forest (3) & for all strata, except for the landless \\
\hline
\end{tabular}

Table 2.4: Main assumptions for setting up the model. For the setup of the quasi-stationary model several assumptions were made. They were based on data and personal observations and mostly aimed at simplifying the model. 



\section{QUASISTATIONARY MODEL: STATUS QUO}

\subsection{Farmers' Strata}

\subsubsection{Land Use}

Figure 3.1 shows the farmers' crop options for the two harvest seasons primera and postrera. It depicts what percentage of farmers opts for a certain annual crop. Clearly, most farmers prefer to cultivate maize and beans in the first cropping season primera, while in the second cropping season postrera all strata opt for beans. Land under fallow is more commonly found in postrera due to the less favorable climatic conditions. This is also the reason why it is easier for the landless peasants to get land in postrera (Figure 3.2), as then they carry the risk or at least half of it - in primera the landowners are less willing to cease their land. Thus, the landless usually farm a smaller plot in primera and a bigger one in postrera. The situation of land scarcity for the landless population is aggravated in primera, as actually some medium farmers rent additional plots. Thus, land for sharecropping or rent is even scarcer. Mostly, landless peasants are obliged to take what they are offered by the landlords under whatsoever conditions. This is mainly sharecropped land, frequently of low soil fertility, as only little land is rented. Therefore, in primera, only $30 \%$ of the landless farmers grow both staple crops. Only 50\% of the landless farmers who have access to land cultivate maize, while 70\% opt for beans (Figure 3.1). Figure 3.1 shows that only the medium and big farmers can afford to have land under fallow, as it is unproductive. The same is the case with unconventional crops (Group "varied") like tomatoes, potatoes, sorghum etc., since their cultivation requires investment capital. 


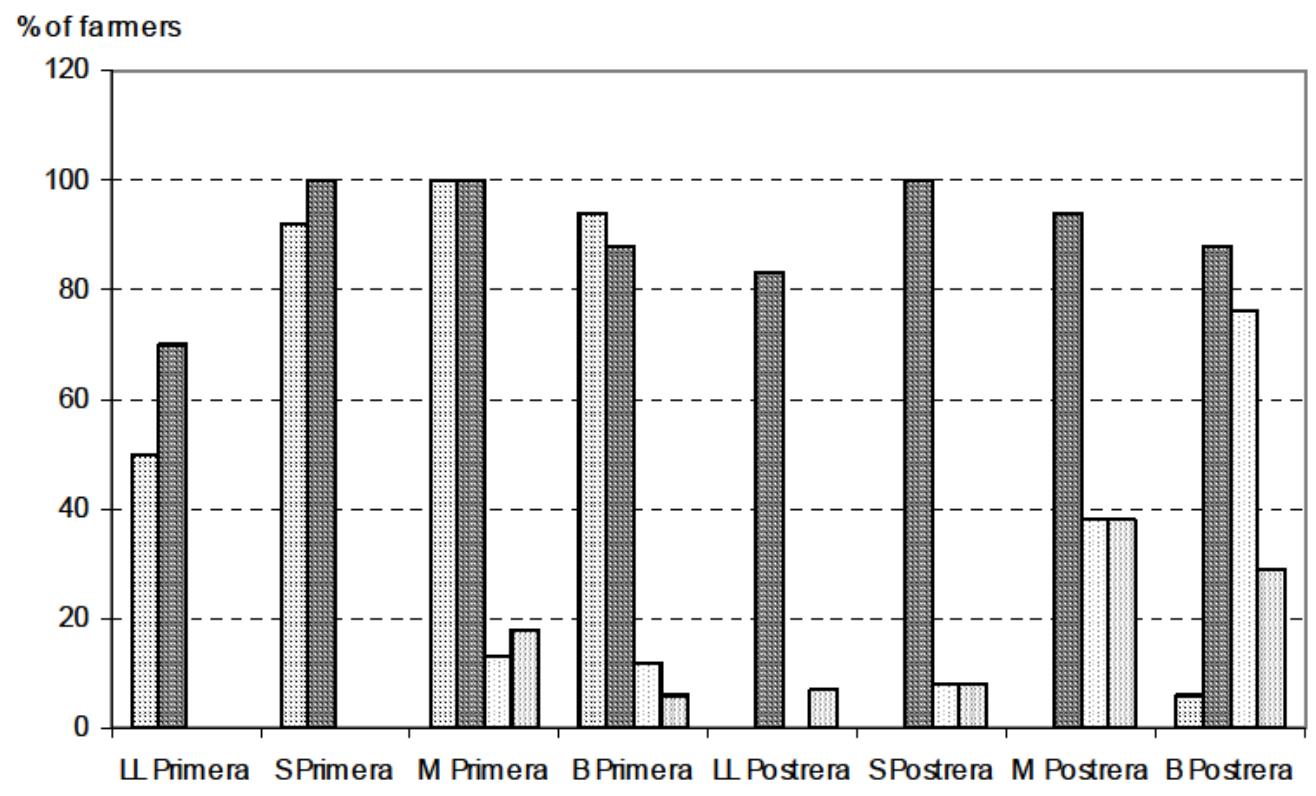

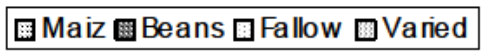

Figure 3.1: Farmers' crop options (annual crops) for primera and postrera. If the farmers manage enough land, most of them opt in primera for both, maize and beans, while for postrera they prefer beans. Only medium and big farmers have land under fallow or under varied crops like sorghum, potatoes etc. (see section 3.1.1). (In this graph the percentage of landless farmers refers to those, which have access to land). ( $\mathrm{LL}=$ landless farmers; $\mathrm{S}=$ small farmers; $\mathrm{M}=$ =medium farmers; $\mathrm{B}=$ big farmers).

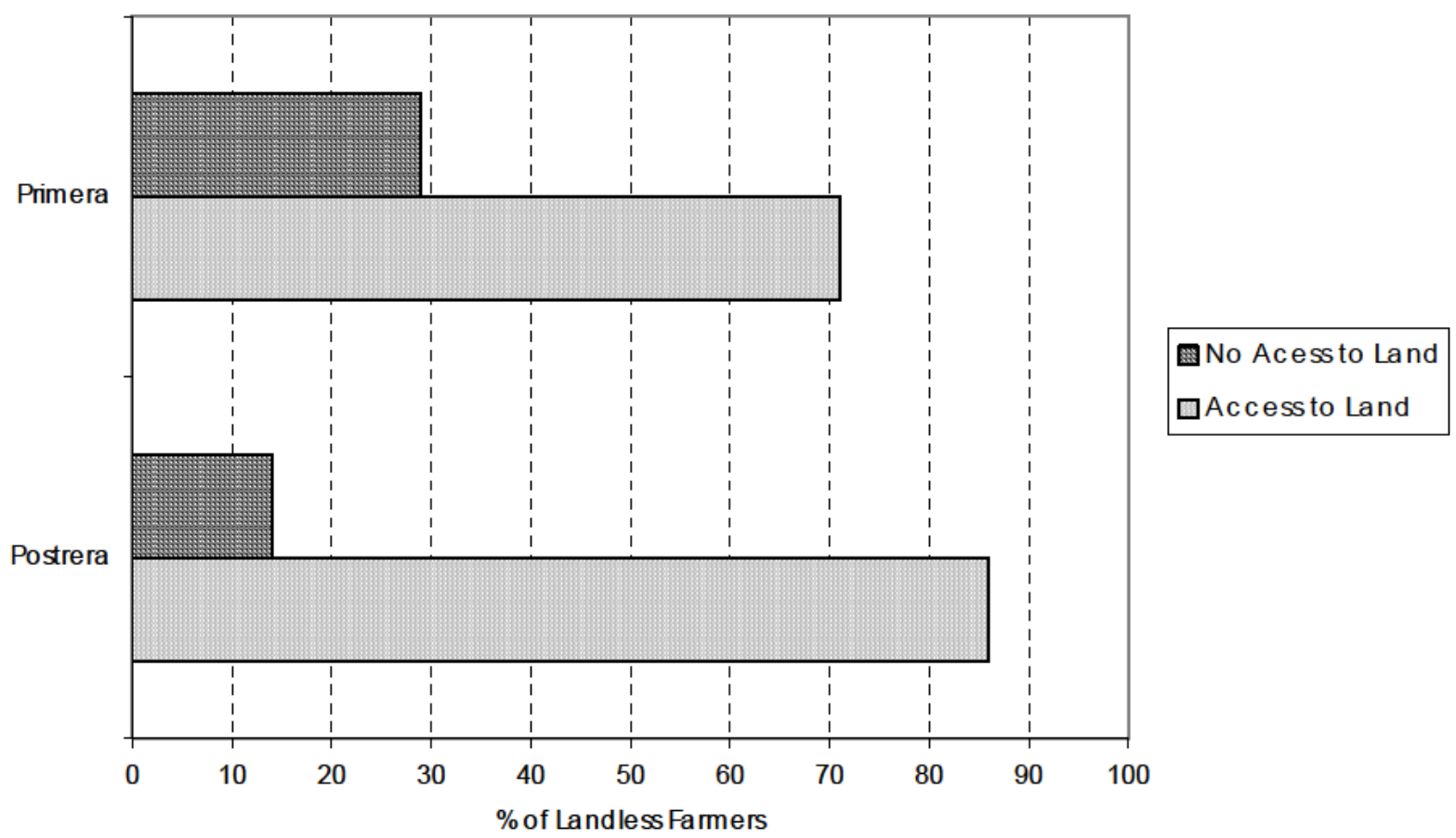

Figure 3.2: Access of landless farmers to land in the two harvest seasons primera and postrera. For landless farmers it is more difficult to sharecrop or rent land in the favorable harvesting season primera (see section 3.1). 
For the same reason growing beans in the third season apante in the mountainous areas is an option for medium and big farmers only. Yet, in none of the strata a majority takes the risk of high investments and an insecure profit represented by apante (Figure 3.3). Therefore apante was not included neither in the farm, nor in the regional MFAs.

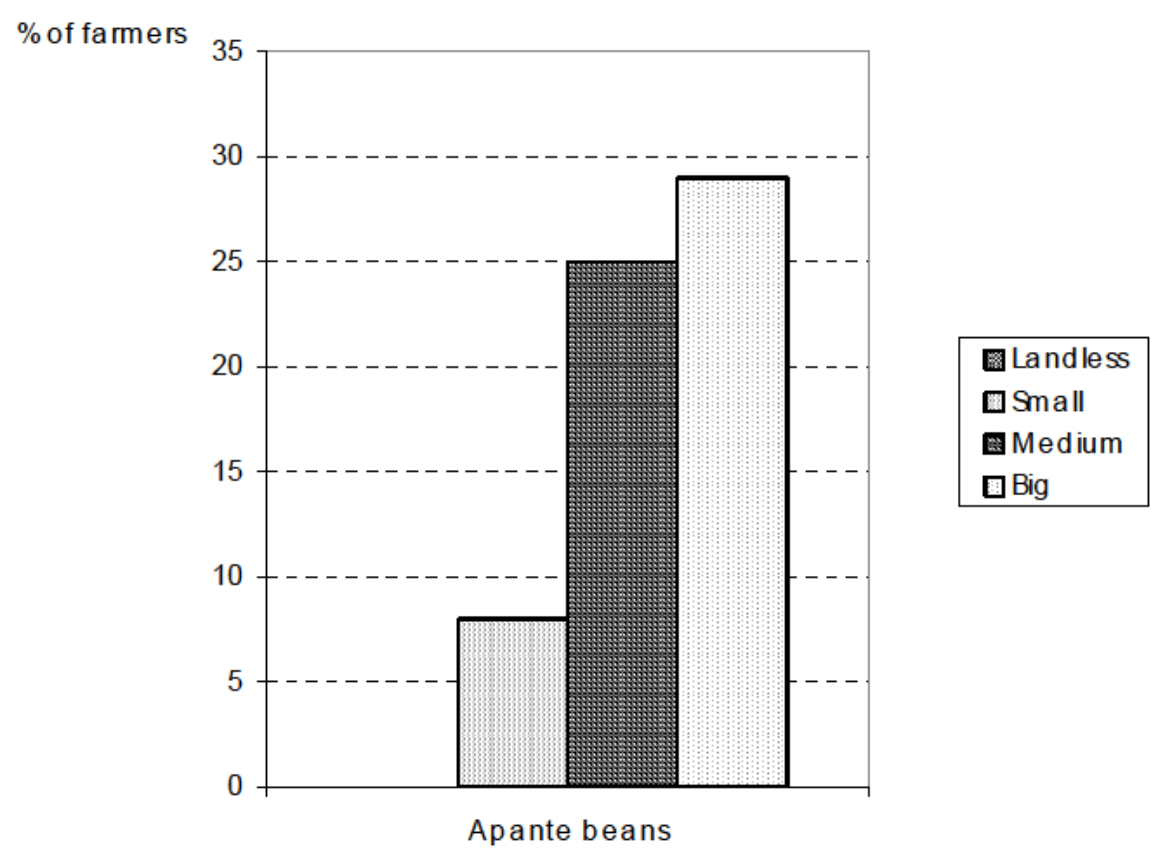

Figure 3.3: The cultivation of apante beans in the mountains. Percentage of farmers that opt for sharecropping beans in the third growing season in the mountainous areas towards the Atlantic Coast (see section 3.1.1). Nevertheless, in none of the strata more than half of the farmers opt for apante.

Figure 3.4 depicts an inverse correlation between land managed and land sharecropped for maize. Thus, the more a certain stratum manages the less it sharecrops. While the landless sharecrop almost $60 \%$ of the maize fields, for the small, the medium and the big farmers this figure lies around $35 \%, 25 \%$ and $20 \%$ respectively. Although the percentage of sharecropped bean plots is also higher for landless and small farmers, the correlation is not found to be so pronounced. This might be due to the fact that maize cultivation needs a lot of chemical inputs ${ }^{16}$ and is linked to high investment. The landless peasant can hardly get credit ${ }^{17}$ and is therefore dependent on a landlord to provide the inputs and the land, while he supplies all the

\footnotetext{
${ }^{16}$ Maize is fertilized twice and usually treated with pesticides once or twice.
} 
work. Small farmers, in contrast, are often short of labor as the mean family size is somewhat smaller. On the other hand, they are also short of credits and might therefore be interested in making a deal with a sharecropping partner, who provides part of the chemical inputs. For the medium and big farmers sharecropping maize is linked to investments and risk, as they usually supply all the inputs. If the tenant does not care about the crop they can loose money. Therefore, they prefer not to sharecrop too many of their maize plots, but to employ a steady workforce. Nonetheless, all farmers' strata sharecrop a bigger percentage of maize than of beans. Only for the small farmer this figure is about even. Probably this is due to the fact that with beans bigger profits can be made. Thus, who can afford it, tries to get it all, not just half of it.

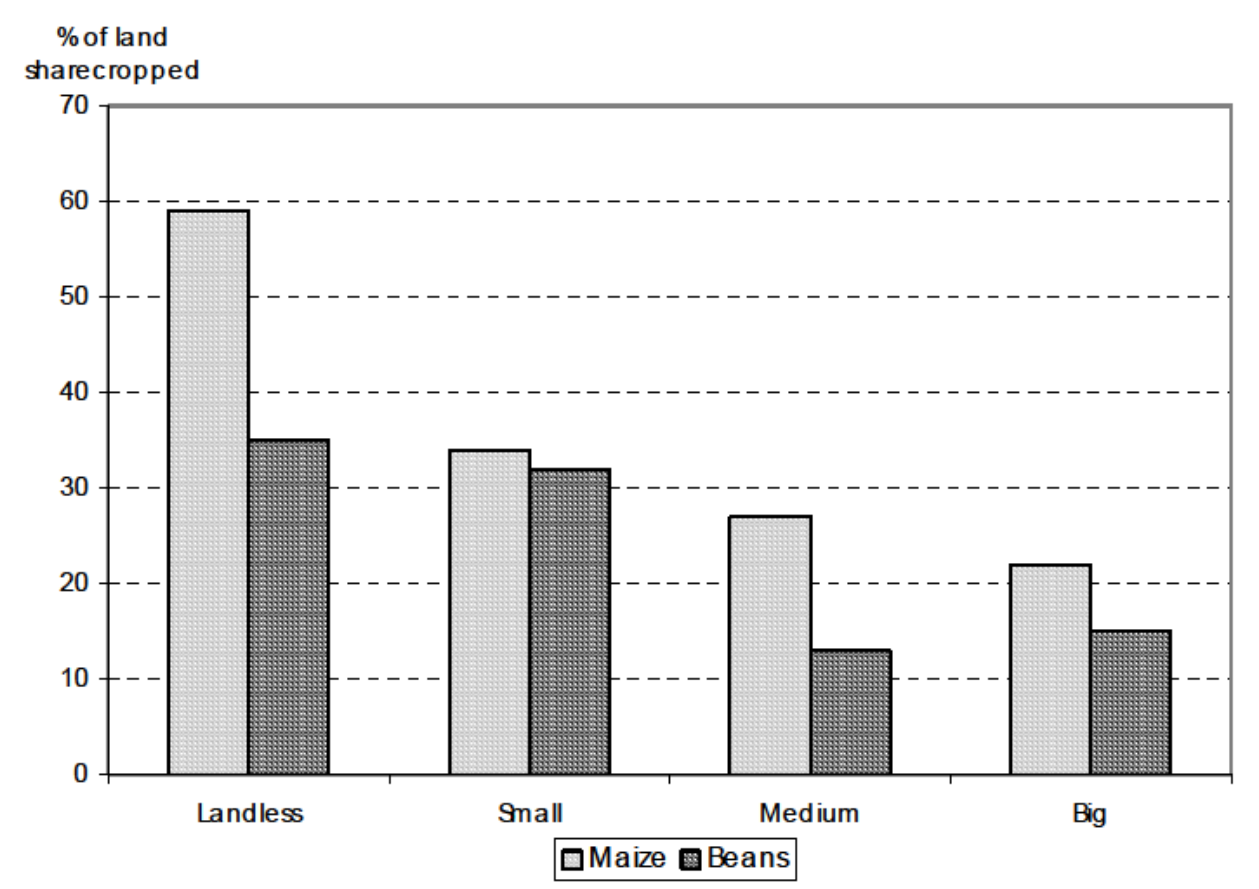

Figure 3.4: An inverse correlation between land managed and land sharecropped exists. For maize this relation is pronounced: The more land a certain stratum manages the less it sharecrops. For beans the correlation is found too. Nevertheless, it is not so marked.

Figure 3.5 shows the land use for the land managed (landless) and the land owned (small, medium, big). The sharecropped land is not separately listed, while the land

\footnotetext{
${ }^{17}$ Poor households receive significantly less credit and have less access to technical assistance than non-poor households (Davis et al., 2001).
} 
rented to others is. It becomes evident that the more land the farmers have access to the more varies its use.

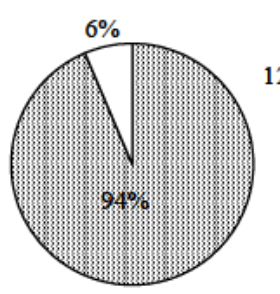

Landless

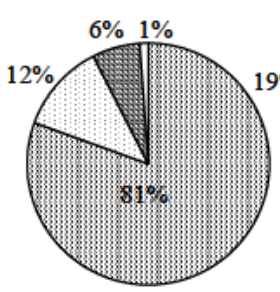

Small

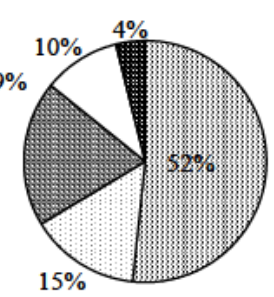

Medium

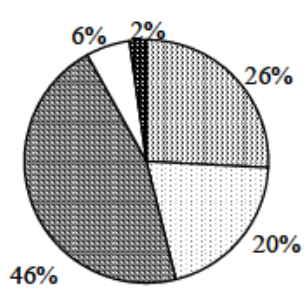

Big

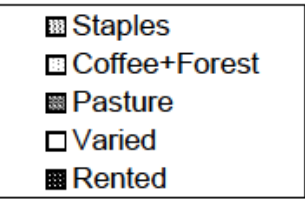

Figure 3.5: Land use of farmers' strata. Land use differs considerably between strata. While landless farmers only grow staples, small farmers additionally own small coffee plots. In both cases the share of varied crops and pasture represent one farmer due to the small sample and are thus not relevant. Medium and big farmers are more diversified. The former grows perennial crops (coffee and forest, pastures) in addition to staples and rents land to other farmers. Besides staples, big farmers manage a considerable amount of coffee, forest and pastures. (see section 3.1.1).

Thus, landless farmers grow almost exclusively staples ${ }^{18}$. Small farmers also grow mostly staples, but they are already somewhat diversified. Roughly $10 \%$ of their land is used for coffee forest. This results from the fact that they are landowners. As they formally own the land, they can make long-term investments on it. The area on which small farmers grow varied crops is negligible ${ }^{19}$. The medium farmer uses about half of his land for growing staples, about $17 \%$ for coffee and forest and about $20 \%$ for pasture. Even though the majority of medium farmers does not own cattle, they plan on it. Meanwhile, they maintain pasture for their horse and they host animals of other farmers against a fee. The medium farmer also rents crop land. Nevertheless, he does that only in postrera, while in primera he actually leases additional land from others. The big farmer uses almost half of his land for pasture. $25 \%$ of the land is used for staple growing. On $20 \%$ coffee and forest is grown, while only $17 \%$ is used for varied crops (tomatoes, sorghum, potatoes). Only $2 \%$ of the land is rented to other farmers. There is an additional category of ceding land to others, namely just borrowing $\mathrm{it}^{20}$. Yet, this category, mainly custom among family members, was hard to grasp through

\footnotetext{
${ }^{18}$ The share of varied crops can be attributed to one individual, who sharecrops sorghum with his patron in postrera. Due to the small sample this makes up for six percent of the total, but in reality this percentage is certainly smaller (personal estimation: 1$2 \%$ ).

${ }^{19}$ One small farmer owns pasture land, which again makes up for six percent of the total.

${ }^{20}$ This is sometimes combined with the payment of a symbolic harvest share.
} 
the interviews. Nevertheless, it can be assumed that the big farmers share more land with outsiders than presented here. Furthermore, medium and especially big farmers can diversify their income sources within and outside of the agricultural branch. Thus, they grow coffee, which in a good season could produce reasonable profit until some years ago. Moreover, these farmers have the opportunity to spare out land for growing non-conventional crops. Big farmers have an additional income source with livestock. Last but not least, as medium and big farmers do not need to invest all their energy just to satisfy their physiological needs, they can, if interested, participate in NGO workshops and similar activities. This opens them new possibilities and further knowledge about e.g. the nutrition of livestock. The results for landless and small farmers, on the other hand, show that these families depend almost exclusively on staple production. Thus, the consequences of a bad staple harvest hit them especially hard and their resilience is low.

Animal holding of the four strata is shown in figure 3.6: While independently of the stratum most of the farmers own poultry, mainly the higher income strata own pigs.

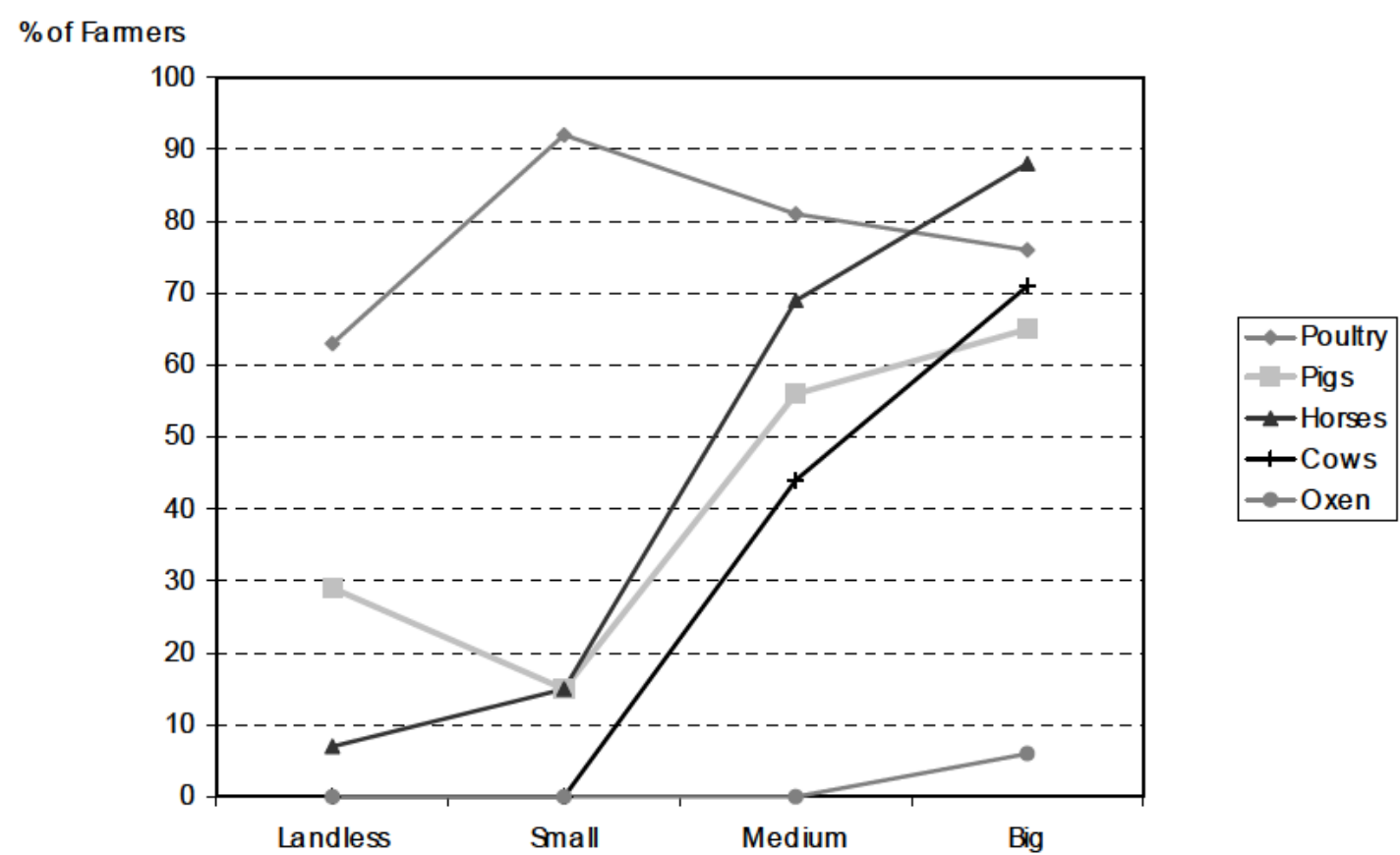

Figure 3.6: Animal holding by farmers' strata: Percentage of farmers of a given stratum who own a certain type of animal. All strata own poultry, while the holding of bigger animals increases with farm size (see section 3.1.1) 
The difference between landless farmers, of which almost 30\% own pigs, and small farmers, of which only half of those (15\%) do, probably results from the small sample. Other studies for the whole region of San Dionisio show a higher percentage of pig holders (38\%) among the small farmers (Leemann, forthcoming). Not surprisingly, there is a clear correlation between horse, mule and cattle ownership and land holding as only farmers with sufficient land can afford to use part of it to raise animals. The only examples to this are small farmers whose family or in-laws own enough grazing area to feed his horse in addition to their own livestock. Owning animals serves as a security system: the animal stock owned by these farmers provides income throughout the year and serves as living bank account, which can be sold in case of emergency.

\subsubsection{Nitrogen Mining}

For landless, medium and big farmers staple production is found to cause more Nmining than other agricultural activities (Table 3.1). The small farmer is the only exception, as he mines about $15 \mathrm{~kg} \mathrm{~N} / \mathrm{ha}^{*}$ a less than the other strata. This is tightly linked to production figures, as the small farmers produce least basic grains per ha. Thus, less nutrients are removed with the harvest. Secondly, plant production is linked to grain production in the model used. Thus, if less grain is produced, the nitrogen loss caused by field burning is lower too. As this does not always correspond to reality - e.g. crop destruction due to attack by pests - it can be stated, that all farmers' categories were found to mine nitrogen at roughly the same magnitude per ha.

As mentioned before, the process causing major nutrient mining is food production. Again the small farmer is the exception, as he mines more nitrogen on his coffee \& forest plots - even in a balanced system. The medium farmer mines less on the coffee $\&$ forest areas than on his staple fields, but more than on his plots for animal production, irrespective of what type of management he chooses for the latter. For the big farmer the order depends on the management of pastures. The amount of nitrogen loss caused by staple production is followed by animal production if the pasture is burnt annually. If it is done only once every four years or if it is abstained from, coffee follows staple production. 


\begin{tabular}{|c|c|c|c|c|c|c|c|c|}
\hline \multirow[t]{2}{*}{ Stratum } & \multicolumn{2}{|l|}{ Staples } & \multicolumn{2}{|c|}{ Animal Product. } & \multicolumn{2}{|c|}{ Coffee \& Forest } & \multirow{2}{*}{$\begin{array}{l}\begin{array}{l}\text { Total } \\
\text { mining }\end{array} \\
{[\mathrm{kg} / \mathrm{ha}]} \\
\end{array}$} & nutrient \\
\hline & {$[\mathrm{kg} / \mathrm{ha}]$} & [kg/cap] & {$[\mathrm{kg} / \mathrm{ha}]$} & [kg/cap] & {$[\mathrm{kg} / \mathrm{ha}]$} & [kg/cap] & & [kg/cap] \\
\hline Landless & -33 & -4 & - & - & - & - & -33 & -4 \\
\hline Small & -19 & -7 & - & - & -43 & -2 & -22 & -9 \\
\hline Medium & -37 & -21 & $\begin{array}{l}-17 /-2 / \\
3\end{array}$ & $\begin{array}{l}-3 /-<1 / \\
+<1\end{array}$ & -32 & -5 & $\begin{array}{l}-32 / \\
-29 /-28\end{array}$ & $\begin{array}{l}-29 / \\
-26 /-25\end{array}$ \\
\hline Big & -41 & -34 & $\begin{array}{l}-21 /-6 / \\
-1\end{array}$ & $\begin{array}{l}-33 / \\
-10 /-2\end{array}$ & -14 & -9 & $\begin{array}{l}-25 / \\
-17 /-15\end{array}$ & $\begin{array}{l}-76 / \\
-53 /-45\end{array}$ \\
\hline Region & -31 & -7 & -9 & -1 & -66 & -5 & -31 & -13 \\
\hline
\end{tabular}

Table 3.1: Farmers' strata and nitrogen mining (see section 3.1.3 and 3.2.2): The table shows nitrogen mined by the four farmers' strata for the processes food production, animal production, coffee $\&$ forest and the entire farm (=total nutrient mining). The three numbers for the process animal production indicate pasture management with yearly burning/burning every 3-5 years/not burning. It has to be born in mind that a number of landless work outside of the region or with their parents. They do thus not directly contribute to nitrogen mining, with the exception of firewood consumption. Forests are subject to severe mining. This only becomes evident when looking at the regional figures. These unveil that many people do not own forest resources and do thus gather firewood on the other's plot. This explains the enormous difference between particular nutrient mining for strata and for the region.

It is striking that the regional nitrogen mining out of the process coffee $\&$ forest per hectare is much higher than on any single farm. This is because mining on the farms includes only firewood consumption of the farmer's family for a steady-state system. Yet, all the landless people and partly the small farmers, which do not own any or enough forest, do also supply their firewood from the local forests. Thus, the real extraction rate of firewood and hence the nitrogen mining out of the process coffee $\&$ forest is much bigger for the single farms. The fact that animal production without additional land resources like the holding of chicken and pigs would cause no direct nutrient mining of the farms was an assumption included in the model. Yet, the farming systems with pastures even produce a slight accumulation of nitrogen if the pastures are not burnt. Nevertheless, it has to be borne in mind that erosion has not been included in the model. Doing this might somewhat change the picture, as erosion is reported to be severe on some feedlots for cattle. While between strata there are no substantial differences in nitrogen mining per ha, due to the big differences in 
managed land it differs greatly per capita (Table 3.1). Thus, for maintaining their production system a member of a big farmer's family mines about ten to fifteen times more nitrogen than a member of the landless families. Nonetheless, it has to be pointed out that the landless peasant does not maintain his family with his farming activities. He does neither get the firewood, nor is he able to produce all the food his family needs from the land he manages. So, if we look at the N-mining caused in order to supply his family with all these needs, this figure would be about $3.5 \mathrm{~kg} / \mathrm{cap}$ higher.

In the past the situation was different: Numerous reports testimony the wide accessibility to chemical inputs for all kind of farmers. Although this could not be confirmed in the interviews, probably due to the political aspect of the question, we may assume that in the 1980's nutrient balances were more favorable than they are now. Some farmers claim that the soil has been spoilt by the use of fertilizer and that this is the real reason why they do not produce equally well as before. In coffee production, until the dramatic drop of coffee prices in 2000/01, most medium and big farmers applied chemical fertilizer to their coffee plants, which led to a surplus of nutrients on the plots. This has changed radically, as after the price collapse no farmer has applied chemical fertilizer anymore. Some of them have started using organic fertilizer in order to sell their coffee as an organic product, which obtains a higher price. Yet, there are other requirements like soil and water conservation defined by the purchaser and these have to be carried out during three years until the coffee gets the label "organic". Thus, the farmers consider the growing of organic coffee to be a lot of extra work of which they have not yet seen the benefit.

\subsubsection{Self-Sufficiency}

Interestingly, the family size between the strata does not vary considerably and lies slightly above 6 . The only exception is the small farmers, whose families with an average size of 5.3 are slightly minor than the average (see section 2.4). Thus, in order to have a common basis for comparison, an equal family size and consumption of maize and beans was assumed for all strata. The degree of self-sufficiency was then calculated for maize, beans and energy (firewood) for each stratum. It has to be 
considered, nevertheless, that it is difficult to assess the exact size of the family. Maybe the children live apart, but get their share of meals in hard times. Nevertheless, in Figure 3.7 (status quo) it can be seen that in an average year the landless farmer produces around $50 \%$ of the maize he needs for food and fodder. The self-sufficiency drops to about $30 \%$ with a bad harvest. For beans these figures amount to $150 \%$ and $80 \%$ respectively. In most cases, the landless farmer can therefore not rely solely on the plots he sharecrops or rents, but is constrained to work additionally for landowners or outside of the region.

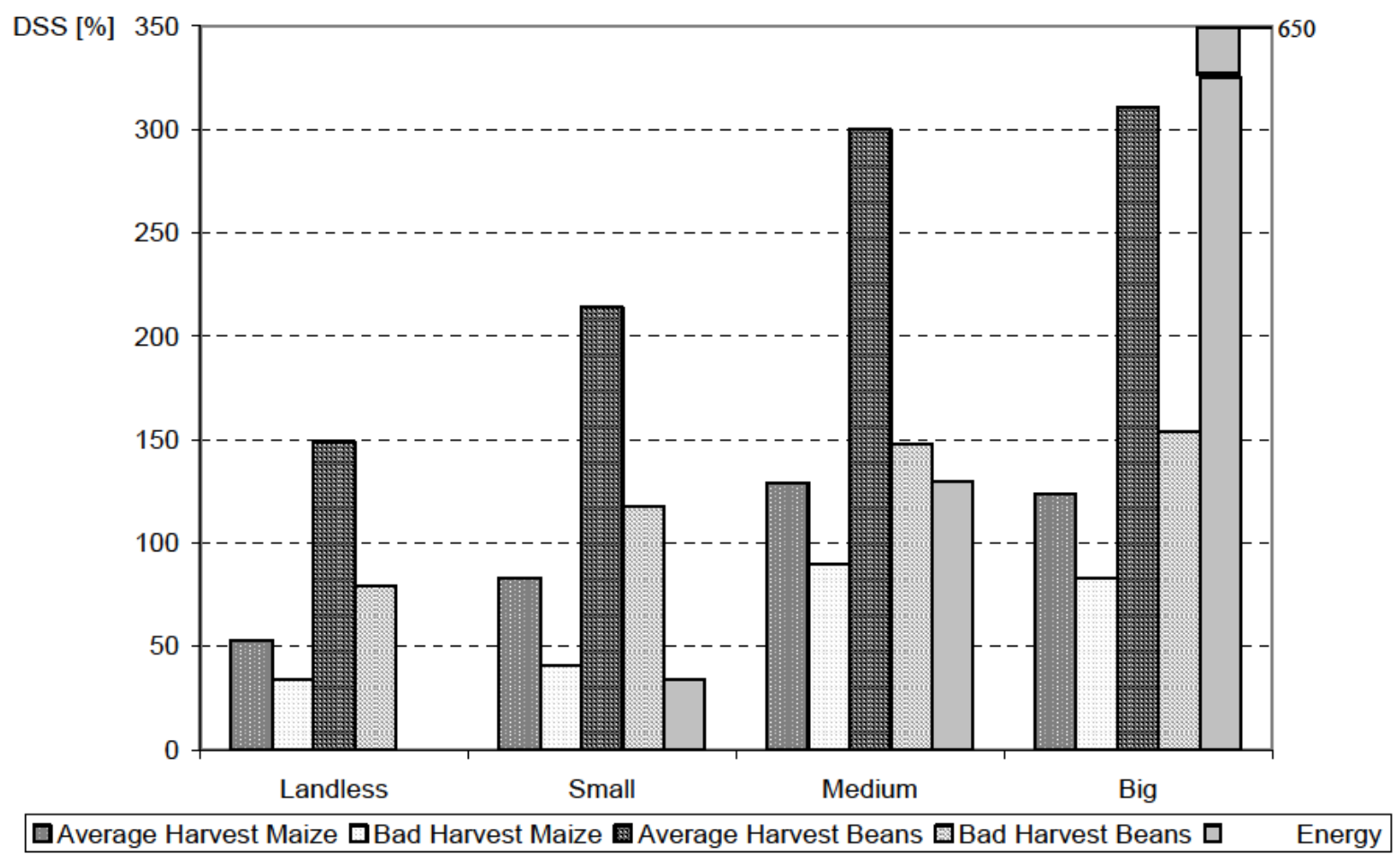

Figure 3.7: Degree of self-sufficiency of the different farmers' strata for staples and energy in an average and a bad year. All farmers' strata are self-sufficient for beans. Small and landless farmers do not produce enough maize and energy. Landless farmers do not dispose of their own energy source (see section 3.1.4).

Furthermore, as he collects the firewood on alien land $\left(\mathrm{DSS}_{\mathrm{E}}=0 \%\right)$, the landless is subject to pressure and has to maintain good relationships with the landowners in order to sustain access to the energy source. With two average cropping seasons the smallholder obtains around $80 \%$ of the maize and $210 \%$ of the beans he needs, while the production is diminished to $40 \%$ of the need for maize and to $120 \%$ for beans 
when the harvest is poor. In a bad year he therefore needs to work off-farm only to supply his family with staples. The small farmer obtains one third of the firewood on his own plots if he aims at a balanced system. Hence, two thirds of the firewood he needs have to be gathered from other plots. Alike the landless, he thus becomes dependent on their owners. While the medium farmer's maize yield exceeds his need for food, fodder and payment of the workers by $30 \%$ in a normal year, this surplus disappears in a bad year and the $\mathrm{DSS}_{\mathrm{M}}$ drops to $90 \%$. Bean production reaches a $\mathrm{DSS}_{\mathrm{B}}$ of $300 \%$ in an average and about $150 \%$ in a bad year. The medium farmer supplies his home with energy derived from his own farm $\left(\mathrm{DSS}_{\mathrm{E}}=130 \%\right)$. In the case of the big farmer $120 \%$ of the maize needed for food, fodder and working force are produced in an average year. The DSS of maize drops to roughly $80 \%$ in a bad year. For beans, $310 \%$ of the need is produced in an average and $150 \%$ in a bad year. The energy of the household derives completely from his own farm ( $\operatorname{DSS}_{\mathrm{E}}=650 \%$ ). Interestingly, although in some years maize is scarce, most farmers stated in the interviews that they preferred buying more grain rather than selling their animals.

In summary, a big gap exists between the strata with access to land and those lacking or partially lacking this access in regard to self-sufficiency for staples. The former, namely medium and big farmers have the possibility to produce a considerable surplus in staple production. Although some of it may have to be sold immediately in order to repay loans, the rest can be stored until a better price is paid on the market.

Furthermore, it has to be pointed out that the more land the farmers own, the smaller is the possibility to get a bad harvest. Many times yield reductions are caused by plagues, which act locally and may destroy the crop of one plot. For farmers relying solely on this plot, the loss is therefore total. On the other hand farmers cultivating various plots may get good harvests on some of them. Even with negative climatic effects upon the yield bigger farmers are better off, as their plots are distributed widely and may belong to different soil types with different characteristics. And, as perhaps the most important risk diminishing factor, the bigger the holding, the more the farmer relies on crop diversity and cash crop income, which serves as a cushion for difficult periods. 


\subsubsection{Covering Basic Needs - The Canasta Básica}

The coverage of basic needs in an average year is depicted in Figure 3.8 for the farmers' strata. It is alarming that landless farmers are able to cover only about $20 \%$ of their basic needs. In other words, if they aimed at buying the items contained in the canasta básica, two members of the landless families would need to work six days a week the whole year round - in addition to the person working on the fields. Small farmers are also far from covering the costs of the basic needs. They earn $60 \%$ of the value of the yearly canasta básica. In order to complement the lacking money, one person per family would need to find a full-time job for six months of the year. The problem is that there is a severe lack of jobs in the region. For the medium farmer, in an average year the basic needs are covered 1.5 times. Thus, there is a surplus left, which can be used elevating the standard of the canasta básica, investments in the farms or savings for bad years. Lastly, big farmers have an income which covers roughly 2.8 times the costs of their basic needs. In addition to this, most big farmers have further income sources such as grocery stores, cattle trade etc. Thus, in reality medium and especially big farmers have an even higher income than the one used for the calculation of Figure 3.8.

In order to have an idea of the standard of living feasible for landless and small farmers, the content of the canasta básica was drastically reduced to only the basic foodstuffs and called canasta mínima, minimum needs (Figure 3.9). Of those, the landless farmer is able to buy about 55\% with the income of his farming activities. Thus, in order to compensate for the lacking items, one family member would have to find work for half a year. If no job is found, the families will go hungry - not to speak of lacking medical treatment and schooling. This is actually the case, as numerous persons in the region stated. The small farmer on the other hand earns 1.4 times the costs of the canasta mínima. Nevertheless, it has to be stressed that the minimum needs correspond by no means to the principle of human dignity. Like its name says, it represents a minimum for survival. 


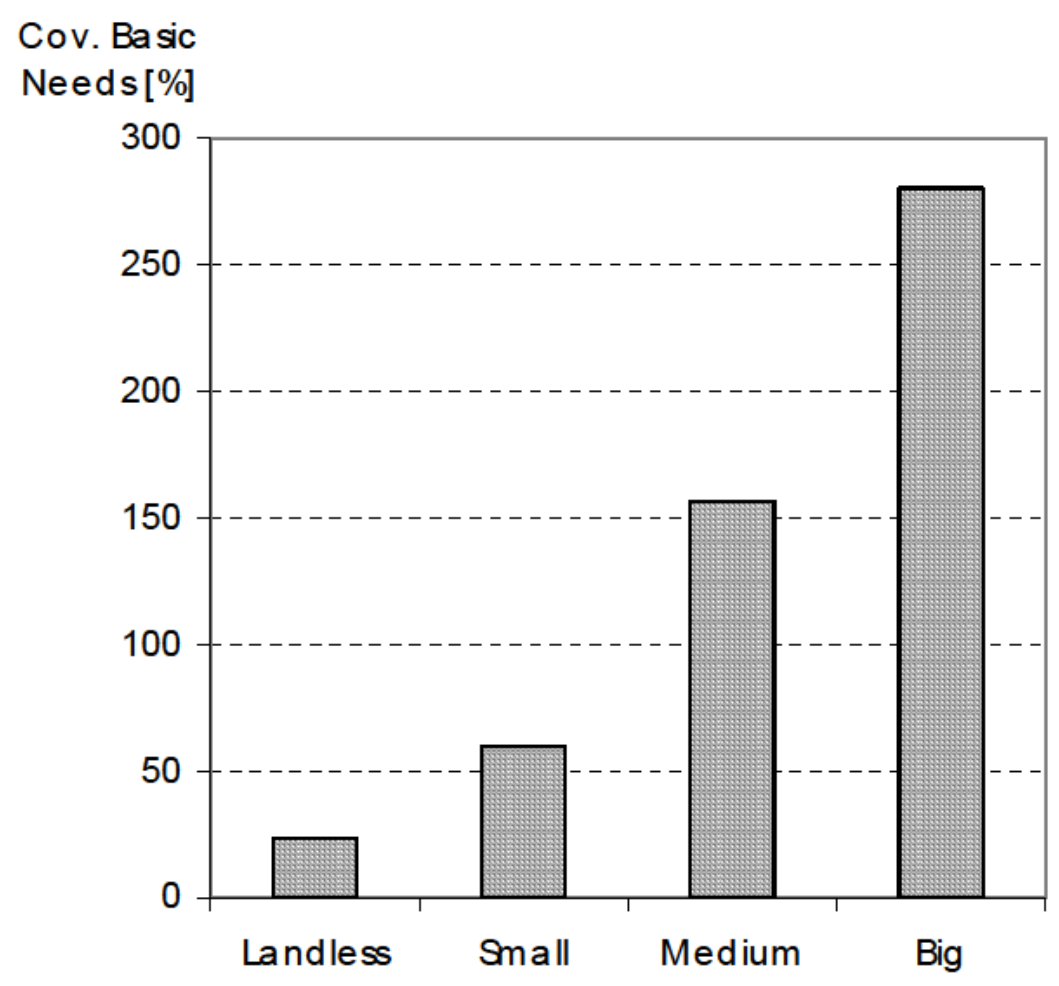

Figure 3.8: The coverage of the canasta básica (basic needs) by the different farmers' strata with agricultural activities. Landless and small farmers are far from covering their basic needs. Medium and big farmers are able to purchase the canasta básica. (See section 3.1.4).

Cov.

Minimum

Needs [\%]

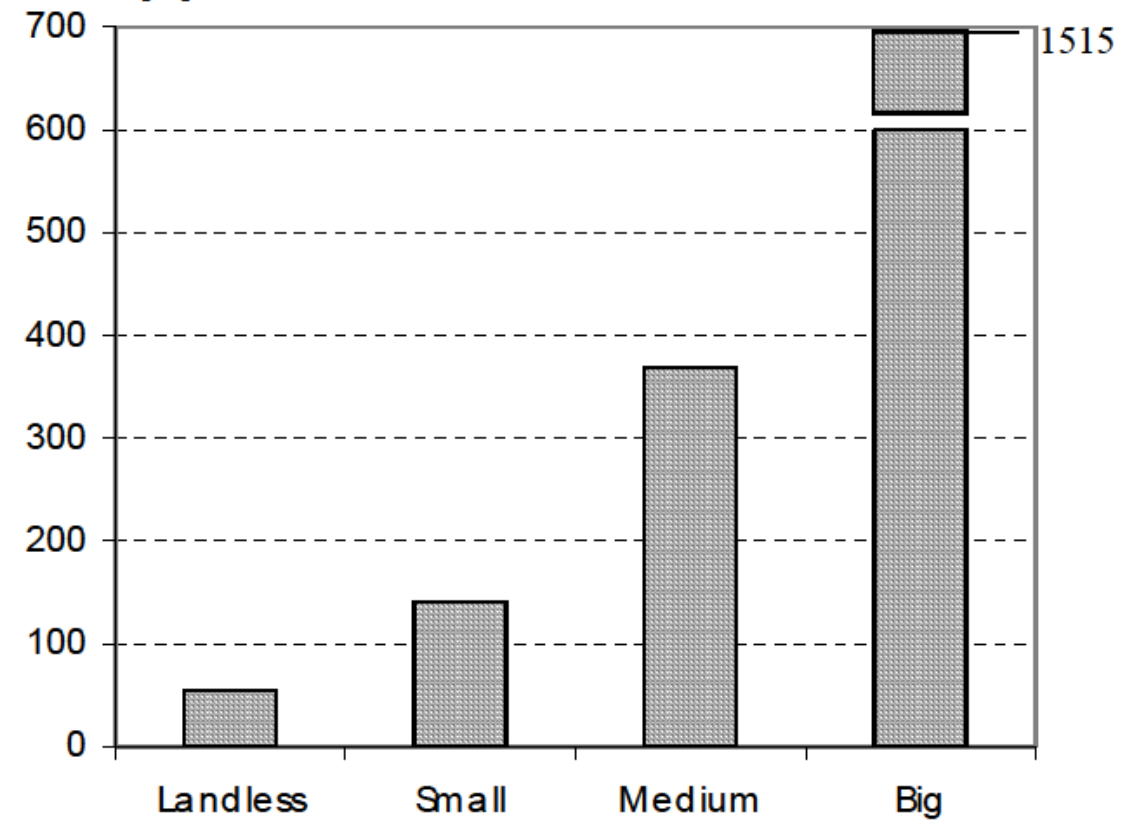

Figure 3.9: The coverage of the minimum needs by the different farmers' strata. While all the strata with own land can cover their minimum needs (basically staple foods) with agricultural activities, the landless do not. They can only come up for about $55 \%$ (see section 3.1.4). 
In summary, landless and small farmers have a low coverage of the canasta básica and are therefore not able to meet their basic needs. This is striking if we keep in mind that these amount to only US\$ -.60 per person and day. This precarious situation affects their living conditions in general (housing, hygiene, education). It also causes a lack of security, as in case of emergency part of the land or the food stocks has to be sold. The lack of means also hinders small farmers from reinvesting into their own farm. The landless farmer is usually constrained to his way of living, if there are no possibilities of land heritage within his own family. Participation in projects may often be restrained due to the lack of own land.

\subsection{Region}

\subsubsection{Land Use, Population and Strata}

Currently (status quo), 500 families live in Susulí, on an area of roughly $12 \mathrm{~km}^{2}$. The population density is 250 inhabitants $/ \mathrm{km}^{2}$. Half of the families are landless and roughly a third are smallholders. Only 15\% are medium farmers, and 5\% are big farmers (Leemann, E., forthcoming) (Table 2.2). About half of the land in the region is used for annual, the other half for perennial crops (Figure 3.10). Annual crops are mainly staples. Thereof one quarter is maize, and three quarters are beans. The fallow area is negligible. The permanent crops grown are coffee, forest and pasture. Coffee and forest cover roughly two fifths of the area used for perennials and $17 \%$ of the total area. The remaining three fifths are used for pasture, which cover more than $25 \%$ of the total area. 


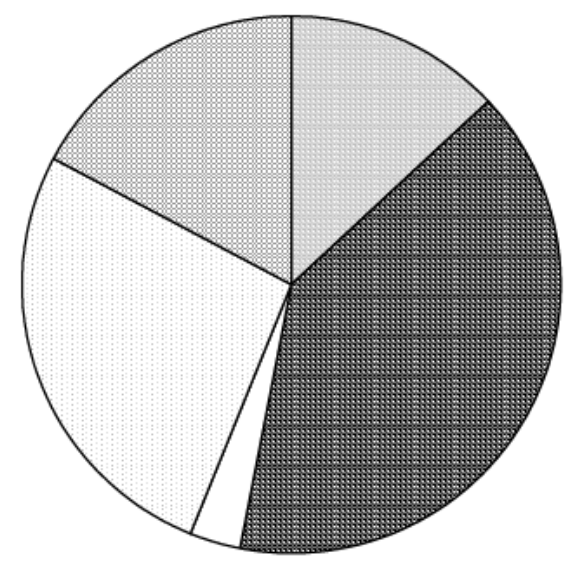

口Maize 圆Beans $\square$ Fallow $\square$ Pasture $\square$ Coffee \& Forest

Figure 3.10: Regional Land Use: More than half of the land is used for staples. Perennial crops are pasture ( $25 \%$ of the total land) and coffee \& forest (almost $20 \%$ ) (see section 3.2 .1 ).

\subsubsection{Mass Fluxes and Nitrogen Metabolism}

In Figure 3.11 the mass fluxes of the region of Susulí are shown. The commodities considered are restricted to agricultural and forest production of biomass and the consecutive consumption. Not included are other key resources such as water and construction materials. The fluxes are clearly dominated by firewood and the waste gases caused by its burning, which are 2-3 orders of magnitude bigger than most others. Further important mass fluxes are waste gases caused by plant residue burning in the process food production, food autoconsumption and the share of the harvest sold.

Figure 3.12 depicts the capital importance of the process food production for the nitrogen turnover of the region. Most of the major fluxes in the system lead to or derive from food production. Another relevant process is farmers' households, which gets food and cooking energy from the system and generates waste. For the region coffee \& forest is at present mostly relevant as a firewood source, since coffee harvest has dropped considerably as a result of suspended fertilizer applications. Concerning nitrogen turnover, the process animal production is not relevant to the system as a whole. The most prominent N-loss of the system is waste gases deriving from the process food production, followed by harvest sold to the Hinterland. It is noteworthy 
that nitrogen deposition and biological nitrogen fixation together with the mineral fertilizer input could come up for the nitrogen losses from the process, if the production of waste gas was considerably reduced by abstaining from crop residue burning and by a different fertilizer handling. Therefore, the mining of nitrogen stocks out of food production could theoretically be reduced to zero. Another relevant flux is the nitrogen lost to the management system through the deposition of human feces in latrines which are sealed after filling (waste). Its sum is equal to half of the nitrogen imported in form of mineral fertilizer. Thus, an efficient waste management could considerably contribute to a more sustainable nutrient management. Last but not least a considerable quantity of firewood is used for cooking:

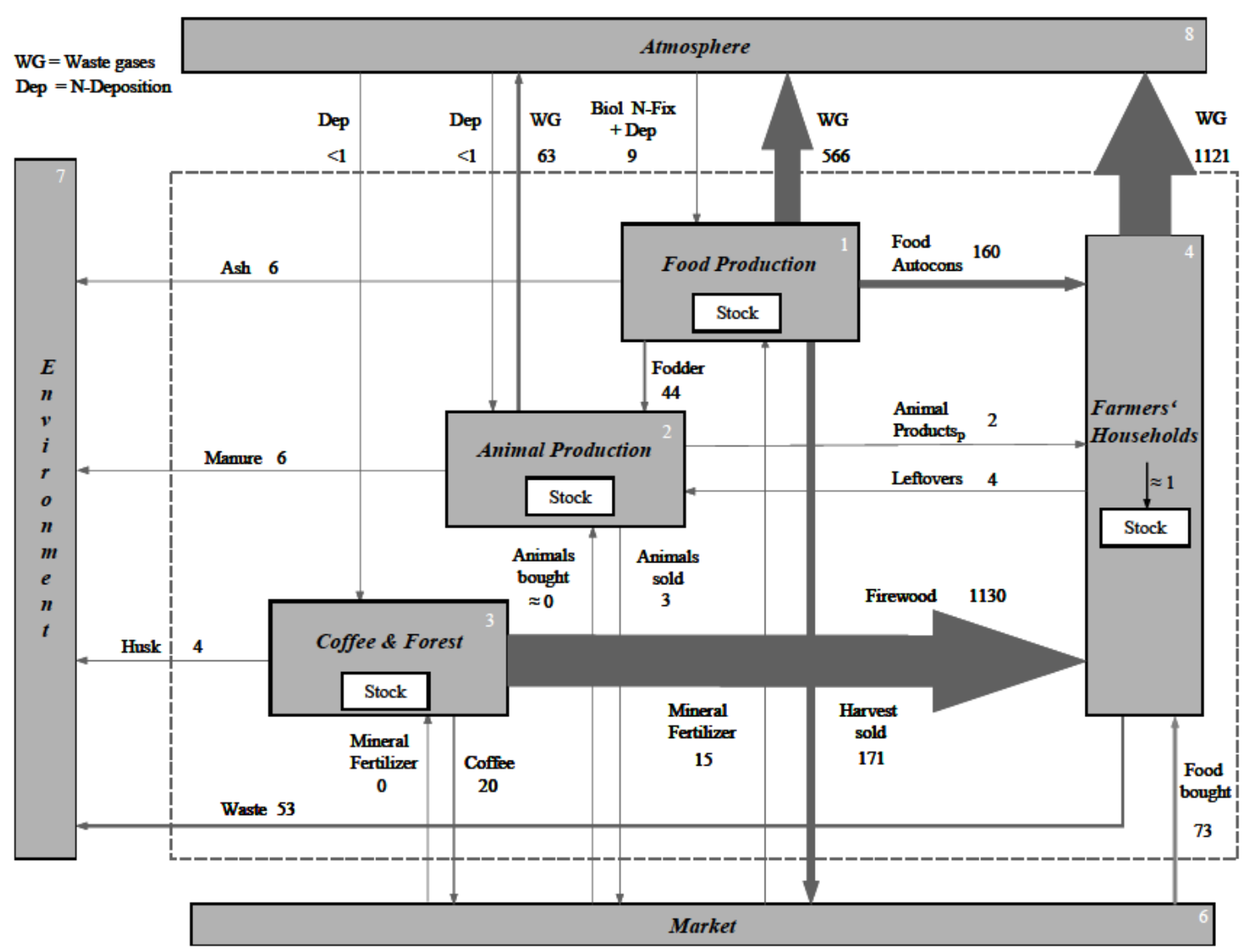

Figure 3.11: Regional mass fluxes (kg DM/cap*a) for the region of Susulí. The dominant fluxes are firewood from the process coffee \& forest and waste gases associated to burning activities. 
Hence, although the nitrogen content of firewood is small, its extraction leads to a diminishing nitrogen stock of the process coffee \& forest. Furthermore, its burning causes a nitrogen loss from the system to the atmosphere. The latter cannot be reduced per se, but only with technical improvement of cooking facilities. Thus, by using e.g. pressure cookers the time for preparing beans shortens from $3 \mathrm{~h}$ to $1 \mathrm{~h}$. The actual energy demand amounts to roughly $17 \mathrm{GJ} / \mathrm{cap}^{*}$ a. It is thus $70 \%$ higher than a well equipped kitchen of a developed country (Faist, 2000). Improved stoves, for instance, could lead to firewood savings of up to $40 \%$ (Kammen, 1995, cited in WEC/FAO, 1999). They were unsuccessfully introduced in some homes in the municipality of San Dionisio by an NGO.

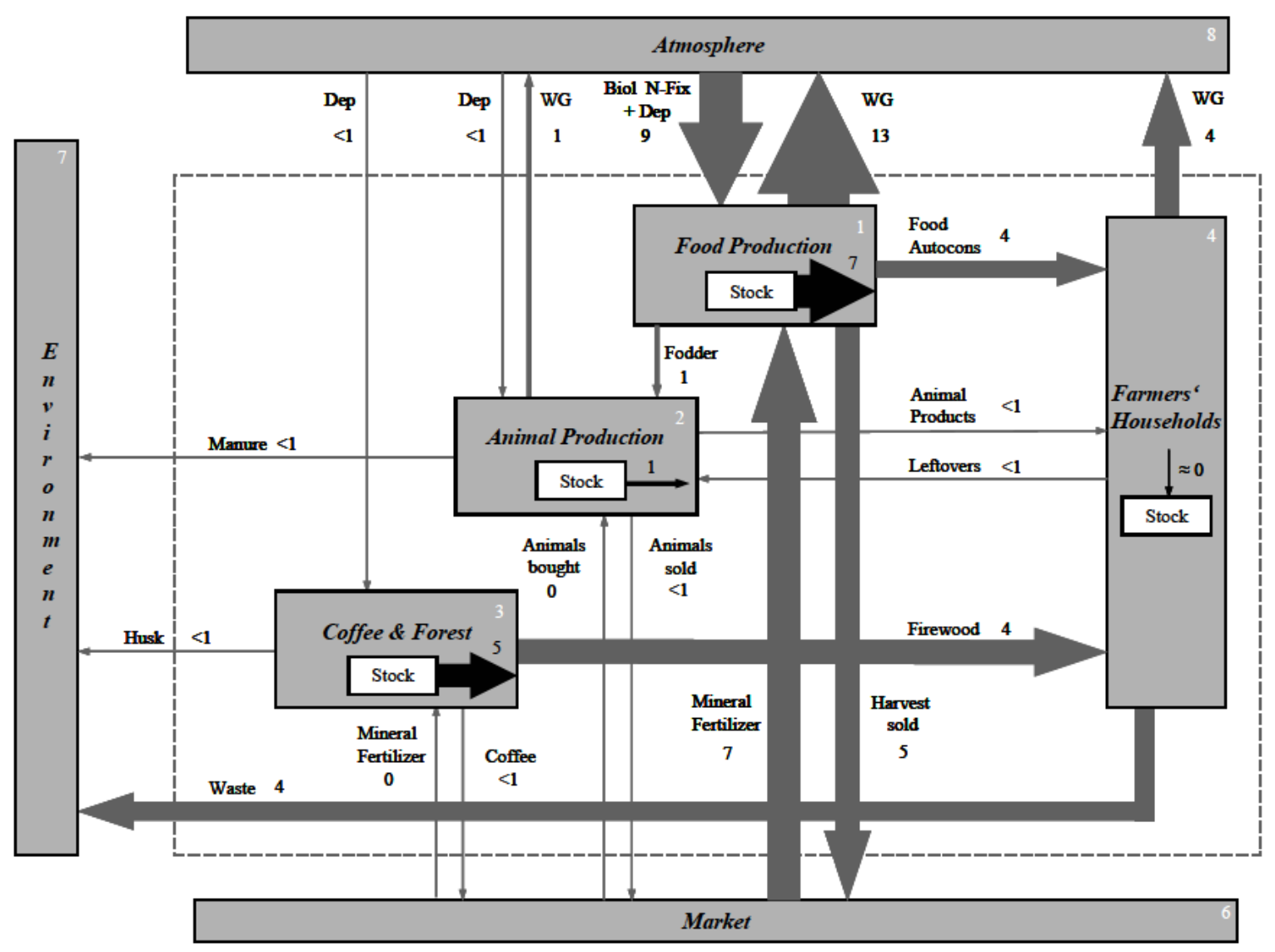

Figure 3.12: Regional N Fluxes (kg/cap*a) for the status quo. The fluxes dominating nitrogen metabolism are mostly associated with food production. Nitrogen is mined mainly from the processes food production and coffee \& forest. For the former, waste gases, caused by crop residue burning, is most important single factor responsible for $\mathrm{N}$-mining. Nitrogen stocks for the three production processes are estimated to lie around $3000 \mathrm{~kg} / \mathrm{ha}$ (Pagel, H. et al., 1982). 
Furthermore, there are small solar cookers. Thus, alternatives for saving firewood exist. But they have to be adapted to local conditions and introduced in a participatory manner. It is interesting to note that until the dramatic drop in coffee prices in 2000, nitrogen balances for many coffee \& forest plots were positive, as fertilizer was widely used by big and some medium farmers, who used to have better harvests and a big surplus of $\mathrm{N}$ input.

The process animal production is close to nitrogen equilibrium if pastures are not burned. This might indicate that until now they are not overstocked. Substantial nitrogen mining only arises with pasture burning, which is done by a majority of farmers.

In summary, the farm management has a big impact on nutrient mining. In the study area of San Dionisio it is especially the habit of burning crop residues and applying fertilizer superficially, as erosion and leaching has not been considered in the calculations. If we assume a nitrogen content of $3000 \mathrm{~kg} / \mathrm{ha}$ in the A-Horizon (Pagel et al., 1982), the average current nitrogen mining of $30 \mathrm{~kg} / \mathrm{ha}$ *a consumes the stock in 100 years. Nevertheless, yields drop to zero before there is no nitrogen stock left. This and the fact that farmers have been working on most plots for about twenty-five years shorten the time left. Moreover, although confidential data lack regarding the magnitude of erosion in the area, specialists consider it to be moderate to severe (Rodríguez Ibarra, I., personal communication; FAO, 1995) and it could thus contribute to a great extent to the acceleration of nutrient mining in all processes. Furthermore, nutrient mining is a downward spiral, as the deficiency of one nutrient may have a negative effect on the accumulation of another. Such is the case with low phosphorus availability, which depresses biological nitrogen fixation.

Nutrient mining is not only a consequence of "bad habits", but partly of low prices for agricultural products and the lack of alternatives. If farmers restrain from burning, the preparation of the plot is a lot more work intensive. As a consequence, most of them would have to employ additional workforce. The same is the case for surface fertilizer application. Despite of all this, nutrient dwindling is seen by the farmers to be one of the main problems. 


\subsubsection{Self-Sufficiency}

Currently, with an average harvest, the region exports some maize and a considerable amount of beans (Figure 3.13, status quo). Furthermore, the amount of grain offered for work and grain needed by landless peasants for autoconsumption and animal fodder are approximately equivalent. This means that theoretically the regional maize and bean production is adequate and that in theory peasants can cover at least their staple need with what they earn in agriculture. Nevertheless, it has to be pointed out again that working possibilities are not distributed equally among the landless. Thus, in reality, there are landless families suffering from hunger, while others manage to produce surpluses. If the region as a whole suffers from a bad maize crop only about $70 \%$ of the maize needed is harvested, while with two bad cropping seasons for beans the region still produces about one and a half times the beans it needs.

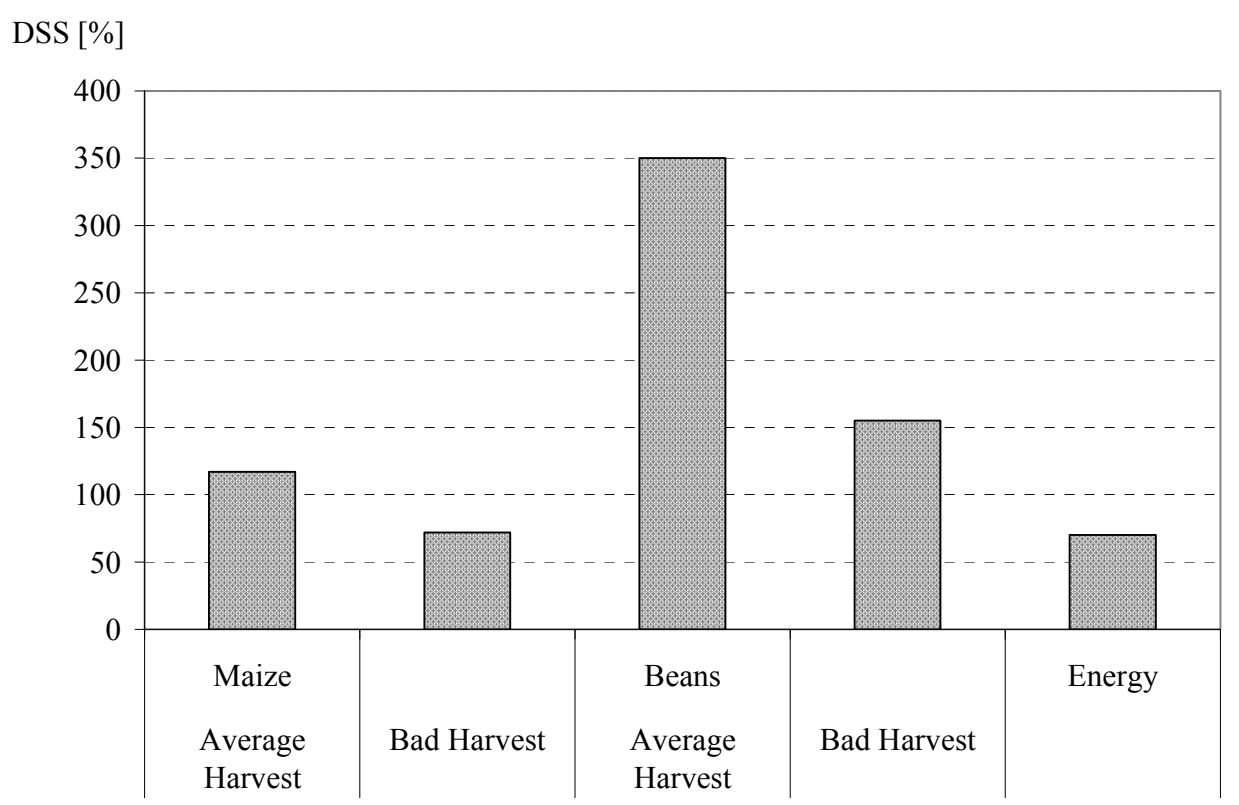

Fig. 3.13: Regional degree of self-sufficiency (DSS) for maize, beans and firewood for the status quo. For the status quo the region is self-sufficient for staples with average harvests, but not with a bad one. The key problem is energy, as only $70 \%$ of the energy need is covered by the natural growth of the forest (steady-state system) (see section 3.2.2).

Nonetheless, the region faces a serious difficulty with energy supply. The current firewood self-sufficiency of Susulí is calculated to be at roughly $70 \%$. This indicates 
that either a considerable part of the firewood derives from the Hinterland, or that actually the resource is already overexploited. Logging forests, although they are private property, is possible because controlling illegal wood gatherers is too costly and unpopular. Rather landowners give neighbors and workers permission to get firewood from their plots. All the same, illegal wood extraction is considered to be a problem by many farmers. Other studies estimate the forest area to be bigger (Leemann and Scheidegger, 2002), which would imply a current regional supply of $100 \%$. Yet, this would solely postpone the problem of energy shortage, as with growing population the firewood extraction rate would soon become unsustainable. Of course, landowners will not allow the clearing of their forests, much less, if cash crops like coffee can be grown. Thus, as a result there may be increased social tensions and conflicts in the communities. Another possible consequence is the change of food consumption patterns due to energy shortages. This would, again, have implications on the farm management and balanced diet.

\subsubsection{Economy}

Theoretically the region is able to supply its population with maize and beans, but the distribution is unequal. Thus, while some families harvest a surplus, others suffer from hunger. Yet, the fact that staple needs are covered does by no means suggest that people lead a life of human dignity. Only a minority of the San Dionisians can live from agricultural activities (i.e. at least cover the familiar basic needs). Thus, for the population given, too little land is available for the current economic environment. Prices of staples and cash crops are low, credits are hardly available, there are no marketing opportunities for alternative crops, etc. Furthermore, the gap between strata also exists for the accessibility of credits and loans. Every year it gets generally harder to obtain credits, and landless and many times even smallholder families are cut off from the resources. This obliges them to sell their harvest beforehand at a low price. The money is used for inputs, but also for covering their minimum needs during the dry season. If they get "real" credits, it is usually from a regional NGO (e.g. CARITAS). Yet, the loans, although necessary, cause farmers to immediately sell their harvest - usually at a low price - in order to repay their debts. Furthermore, if the 
yields are bad, they cannot prioritize food needs, but have to pay their debts. This leads to a vicious circle. Nevertheless, not only the landless and small farmers suffer from the lack of credits and from the vicious circle imposed by them. In my interviews even some big farmers were struck by the precarious situation of the agricultural sector in Nicaragua. Debts and miserable living standards are the reason why many people leave for Costa Rica in search of employment, especially during the dry season. Nevertheless, even for emigration a big difference between strata exists, as the poorest landless families normally do not leave the area. The search for work in the neighboring country uncovers a further major problem: the lack of jobs. Those in agriculture are mainly restricted to work peaks. This situation is aggravating, as more and more big farmers turn away from staple crops to cattle trade. For the given setting, roughly 520 additional jobs would have to be created if the goal was to enable all the inhabitants of Susulí to cover the basic needs. On average, this is more than one employment opportunity per family.

\subsection{Sensitivity Analysis}

A sensitivity analysis was carried out for the nitrogen mining of the whole farm, the $\mathrm{DSS}_{\mathrm{M}}, \mathrm{DSS}_{\mathrm{B}}$ and $\mathrm{DSS}_{\mathrm{E}}$ (see section 2.7). Burning pasture has been neglected in the analysis. The average sensitivity of all strata is depicted in Figure 3.14. The results show that with the exception of $\mathrm{N}$-mining no variable reacts with high sensitivity (section 2.7) to the variation of the parameters by 10\% (Figure 3.14).

$\mathrm{N}$-mining is highly sensitive to the three parameters bean yield, the production of plant material of beans and the transfer coefficient of $\mathrm{N}$ to the air in a burning process. This is on one hand due to the high nitrogen content of beans. Thus, by removing the harvest, a high amount of nitrogen is displaced. On the other hand the bean leaves also contain a substantial quantity of nitrogen. In the model set up leaf (plant material) production is directly linked with bean yield. As the leaves are burnt, this mining, which is considerable, is proportional to the bean yield and the transfer coefficient of $\mathrm{N}$ to the air. For the $\mathrm{DSS}_{\mathrm{M}}$ the parameters directly linked to maize harvest (maize area 
and yield) have a low sensitivity. The same is the case for $\mathrm{DSS}_{\mathrm{B}} \cdot \mathrm{DSS}_{\mathrm{E}}$, on the other hand, is mainly linked to coffee forest parameters.

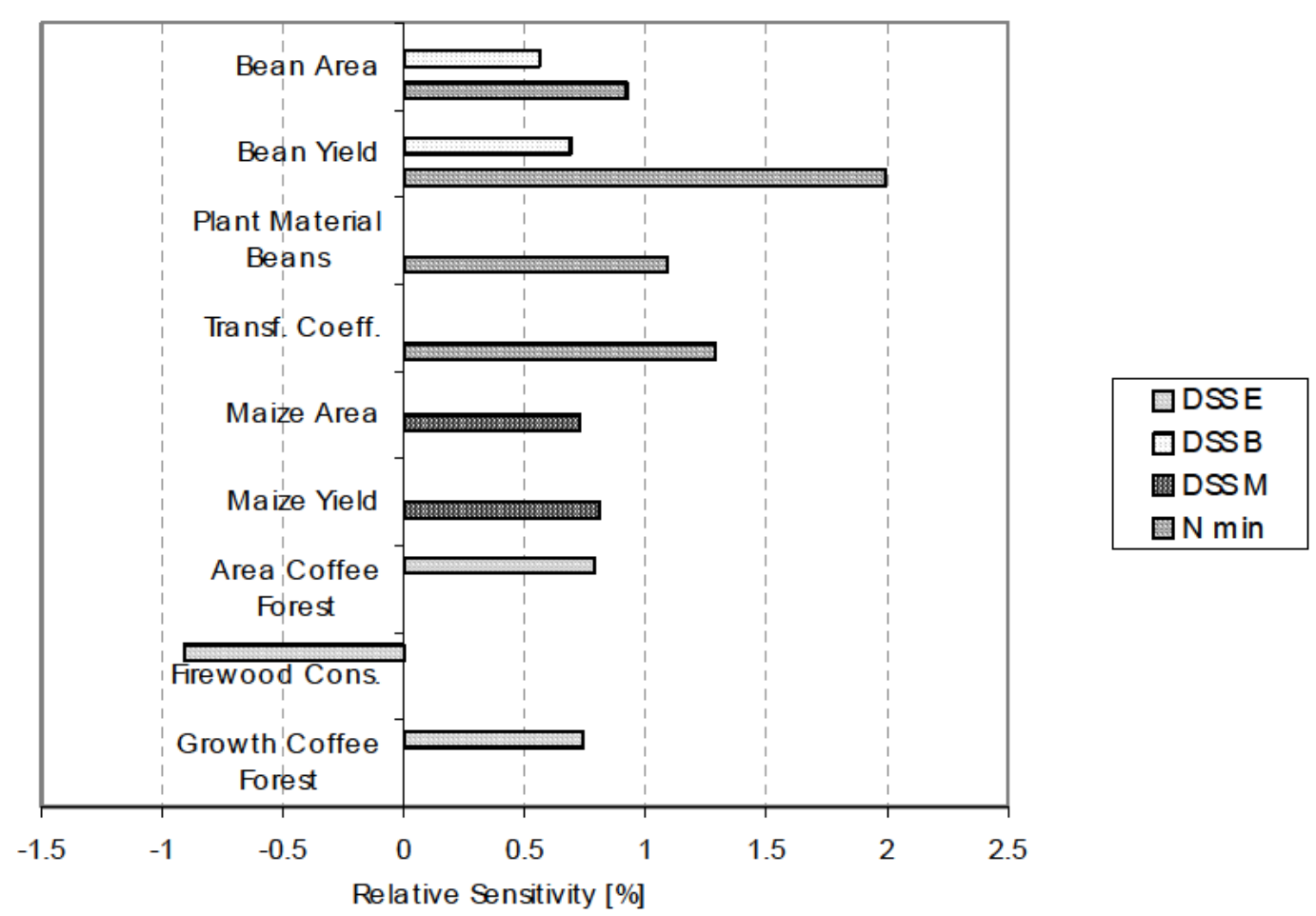

Figure 3.14: Most sensitive parameters for all four strata. There are three parameters which cause a highly sensitive reaction of the variable nitrogen mining. Two of them are related to bean cultivation (bean yield and production of bean plant material). The third one is the nitrogen transfer coefficient into the air for burning processes. For the other variables there is no highly sensitive reaction. They are influenced mostly by the corresponding yield and cultivation area. Thus, for maize it is maize yield and maize area (see section 3.3).

This results from the area for coffee production being much bigger than the one for natural forest. Of course, the $\mathrm{DSS}_{\mathrm{E}}$ is also sensitive to the firewood consumption of the families. Interestingly, animal holdings do not have a big influence on the absolute values of either parameter. In summary, the sensitivity analysis shows that while the assessment criteria nitrogen mining is influenced by some parameters linked to bean production and by the transfer coefficient, self-sufficiency is not dominated by a particular parameter. 


\subsection{Confidence Interval of the Results}

As mentioned before, the method of data collection leads to a quite wide error margin. The question of the confidence interval for the results obtained has to be raised. Are the values significant or not? An estimation with extreme values has led to the following results - the true uncertainty is probably smaller:

Taken the example of the big farmers' stratum the range of nitrogen mining has been estimated to be $-40 \% /+60 \%$ in the process food production. It can thus be stated that nitrogen mining does take place on the staple plots. For the process animal production the calculated nitrogen mining without pasture burning of $1 \mathrm{~kg} / \mathrm{ha}$ has a confidence interval ranging from $+1.4 \mathrm{~kg}$ (nitrogen accumulation) to $3.6 \mathrm{~kg}$. Therefore, this process is roughly in equilibrium if pastures are not burned. For coffee $\&$ forest the estimated confidence interval lies between $6.3 \mathrm{~kg} / \mathrm{ha}$ and $20 \mathrm{~kg} /$ ha nitrogen mined. This also indicates that nutrients are being mined, but on a lower scale, which is to be expected of a perennial system. As regards the DSS the following considerations have been made: The DSS for staples depends substantially on the harvest figures and the assumptions made about workforce and wages in grain equivalent. It is about $+/-25 \%$ for maize, and $+/-15 \%$ for beans. This bigger accuracy for the bean figures can be explained with lower differences between regular bean yields and less parameters influencing the $\mathrm{DSS}_{\mathrm{B}}$, which means that there are less error sources. For maize, the following considerations can be made: The interviews confirmed that maize is mainly cultivated for autoconsumption, not as a cash crop. Most farmers grow maize such, that with a normal harvest they may have at most a surplus of $20-50 \%$. Thus, the estimated confidence interval is of $+20 \%$. The lower limit of the interval may well be below a DSS of $100 \%$, as workforce on maize plots often gets paid with money deriving from other sources. Thus, the error margin for $\mathrm{DSS}_{\mathrm{M}}$ is estimated to be at $50 \% /+20 \%$.

The DSS of energy shows the broadest confidence range due to the uncertainties concerning all main parameters. Very conservative assumptions with a low forest area and high firewood consumption were made. Nevertheless, while with a considerably higher forest area $(+70 \%)$ and a lower firewood consumption $(-25 \%)$ the current energy DSS reaches $150 \%$, under scenario 1 it drops to $50 \%$ and in scenario 2 the 
region exports firewood. Thus, although the confidence interval is broad, for increasing population energy supply will become a problem within the next 10-20 years.

\subsection{Conclusions to the Status Quo}

\subsubsection{Evaluation of the Status Quo: Strata}

This study shows that the stratum of landless farmers is the most vulnerable. This is a consequence of the insecure and insufficient or even lacking access to land, the bad quality of this land, dependency on land owners and the difficult economic situation. As the landless family is far from being able to cover even their minimum needs, they are struggling for survival and excluded from the possibility to purchase land. This leads to a vicious circle. The small farmer too is subject to severe limitations. Although he possesses his own land, the choice of crops is narrow. Many crops require considerable investment capital, which the small farmer lacks as he cannot buy even the canasta básica with what he earns in agriculture. Additionally, both of these strata cannot cover their energy needs and depend thus on firewood resources of the other two strata. Both, medium and big farmers are more diversified than landless and small farmers. They also have "living bank accounts" in the form of animal holdings for an emergency. Both of them gain a surplus on the basic needs, which can be reinvested into the farm or into commercial activities. Nevertheless, with their farming activities all four strata mine nitrogen from the soil and thus do not maintain a sustainable farming system. This could, in the future, lead to a severe downfall of production.

\subsubsection{Evaluation of the Status Quo: Region}

The results of the status quo reveal several urging problems in our study region. The primary concern for sustainability is the issue of energy supply. According to estimations based on the available data, without a Hinterland for firewood supply, a change of energy source or consumption behavior, in about 30 years there will be no 
forest left. A second problem is the unsustainable nitrogen management of the farms, mainly of staple production. A fundamental step in changing land management to minimize nitrogen mining is to abandon burning, introduce soil and water conservation (SWC) methods and recycle on-farm nitrogen resources. Yet, this is not an easy task. As Cherrett (2001) justly states, burning cannot be abandoned unless a viable alternative such as agro forestry is on offer. Other studies in Central America have illustrated how difficult it is to change the farmers' long-term behavior in respect to SWC (Schrader, 2002). As regards the self-sufficiency in the region, for years with a bad maize harvest there is not enough corn to cover the needs. 



\section{QUASI-STATIONARY MODEL: SCENARIOS}

\subsection{Scenarios chosen}

Two scenarios have been chosen based on the understanding of the system, global and regional trends and the results of the sensibility analysis as discussed in chapter 3 . An important assumption for the development of scenarios was the following: In neither one of the scenarios production technology changes substantially - some smaller adaptations are mentioned in the scenario description. Assumptions about technical change in agricultural systems are too speculative. Moreover, in Nicaragua, agricultural development in staple production has been very slow since the onset of recording (Godoy and Hockenstein, 1992). Similarly, other boundary conditions like local market prices, the demand for products etc. are kept stable. It has to be borne in mind that scenarios neither aim at depicting realistic development scenarios, nor represent a desirable development goal, be it for the inhabitants, be it for the author. Extremes are chosen and analyzed in order to assess the consequences of radical development schemes. This allows to estimate possible outcomes of real development patterns more accurately, as those most probably lie in between the extremes.

\subsubsection{Scenario 1}

Population is one of the key parameters for development, as per capita regional food and energy consumption, land availability, and the obtainable workforce depend directly on it. In Nicaragua, population is a dynamic parameter since it is still growing fast, especially in rural areas (see section 1.3). Nothing indicates that this will change in the near future: Women's education lags behind, living standards are low and no efforts to promote family planning by any official institution have been observed. 
Since in Nicaragua with each inheritance the land is divided among the descendants, land tenure per family diminishes with each generation. These two factors are reasons for the prevalence of the minifundios currently found in the land ownership pattern in San Dionisio (FAO, 1995). Although it is still possible to emigrate to regions with less population pressure, this will also come to an end when land reserves are exhausted. Based on these facts, the first scenario was created as follows:

In Scenario 1 population continues to grow at 3\% during 25 years (Table 4.1). A land market does not exist, thus farms are inherited to the progeny and divided equally among it. Therefore, landless peasants and their children remain landless, while the property of a particular stratum is divided among the farmers belonging to it. The strata are always defined by the size of the land the farmers own. Thus it may happen that by inheriting and dividing the landholdings a whole stratum becomes part of another one. Farmers cultivate crops and hold animals according to their stratum's characteristics. If they are in a transformation stage from one stratum to another, this is reflected in their land use. The latter is also adapted in cases where any other possibility does not make sense for the farmers.

\subsubsection{Scenario 2}

Raising livestock is a way of avoiding high labor and fertilizer costs in nonmechanized extensive agricultural systems like in San Dionisio: As agricultural labors are mostly done by hand, a farmer can manage a staple farm of a certain size exclusively with family labor. For farms bigger than this, external labor has to be contracted for work peaks or permanently, according to their size. Yet, managing a farm relying too much on non-family workforce is expensive and troublesome. Moreover, income of staple farms depends solely on two crops, which are subject to strong price oscillations. Thus, most big farmers raise cattle: They own too much land to grow staple crops only and the fields may not be suited for other crops. The animals have to be milked and the pasture and fences have to be maintained, but labors do not necessarily coincide with work peaks for staple crops. Furthermore, for Nicaraguan farmers owning cattle is an old dream as it is a sign of wealth. 


\begin{tabular}{|c|c|c|}
\hline Criteria & Scenario 1 & Scenario 2 \\
\hline Population & Growth at $3 \%$ for 25 years & $\begin{array}{l}\text { Population threshold for a new } \\
\text { menu, which is produced on the } \\
\text { farm (self-supply) }\end{array}$ \\
\hline Emigration & None & All above threshold \\
\hline Мепи & Mostly plant based & Mostly animal based \\
\hline Strata & $\begin{array}{l}\text { According to land tenure distinction } \\
\text { between four strata }\end{array}$ & Only one stratum \\
\hline Land Tenure & $\begin{array}{l}\text { Distribution among heirs during } 25 \\
\text { years }\end{array}$ & $\begin{array}{l}\text { Even. All families get the land they } \\
\text { need. }\end{array}$ \\
\hline Land Use & According to strata & $\begin{array}{l}\text { According to animal tenure and } \\
\text { human consumption }\end{array}$ \\
\hline Burning crop residues & Yes (like status quo) & No \\
\hline Animal holding & According to strata & According to menu \\
\hline
\end{tabular}

Table 4.1: The main assumptions for scenarios 1 and 2 . The main assumptions made for the two scenarios concern population density, the menu, land use and farm management (see section 4.1).

\begin{tabular}{ll}
\hline Process & Assumptions for Scenario 2 \\
\hline Food production (1) & Average maize yield for a medium farmer \\
& The crop residues are cut and given as fodder to the livestock \\
& Credits and debts have been neglected \\
& In postrera the land is under fallow \\
Animal production (2) & There is a dynamic equilibrium for animal stocks \\
& No pigs are bred in the region \\
& There are no horses \\
& Cattle only consume pasture \\
& Pastures are not burnt \\
& No animals are sold, all of them are consumed by the regional \\
& population \\
No fertilizer applied to coffee plots & An average yield for low-input coffee \\
Consumption of basic foodstuffs (maize, beans, rice, sugar) is equal \\
for all strata, except for the landless \\
Farmers' Households (4)
\end{tabular}

Table 4.2: Assumptions for scenario 2. The detailed assumptions made for scenario 2 (section 4.1.2). 
Due to rising incomes, urbanization and changing lifestyles, global food projections show an increasing demand for livestock products, especially in developing countries. (Pinstrup-Andersen and Pandya-Lorch, 1994; Brown, 1997). Projections indicate that the total demand for meat will increase by 2.9 percent by 2020 in developing countries (Pinstrup-Andersen et al., 1997). Last but not least, the sensitivity analysis showed a strong link between nitrogen mining and bean production. One possibility to reduce mining may therefore be the substitution of legume derived proteins with animal protein. Thus, the following scenario was developed:

In Scenario 2 people adapt their food pattern to Western European milk, meat, cheese and grain consumption (Bundesamt für Landwirtschaft, 2001) (Table 4.1). Hence, they start holding as many animals as this lifestyle requires and growing the maize needed for food and fodder. The animal stock may fluctuate due to animal diseases (e.g. Exotic Newcastle Disease), against many of which there are vaccines. It has been assumed that animals are vaccinated. The oscillation of milk yield according to fodder quality is taken into account. Since the protein requirements of the population are covered, farmers do not need to grow beans anymore. Further, as a result of the increased number of livestock, maize residues are not burned, but used as cattle feed. Thus, farmers restrain from burning in general (Table 4.1 and 4.2).

Based on these assumptions the number of persons is assessed for whom this living standard can be maintained in the region if land is divided equally among them. Thereby the system should not rely on food or fodder imports from the Hinterland. The rest of the inhabitants emigrate. The current size of the forest area (status quo) and proportions of natural and coffee forest are maintained and divided equally among the inhabitants.

For scenario 2 an own canasta básica (Table 4.3) according to the new menu was elaborated. As the nutrition in scenario 2 is based on animal protein, the aggregate monetary value of the items of these basic needs is higher than of those of the menu based on staples. Thus, the cost of the canasta básica of this scenario is almost $40 \%$ higher than the cost of the basic needs of the status quo. This results from an increase similar in size of the value of foodstuffs, as the cost of clothes, education and medicine have not been changed. No minimum needs have been elaborated for 
scenario 2, as the menu plan can easily be cut back on meat and cheese consumption without running the risk of malnutrition.

\begin{tabular}{|c|c|c|c|}
\hline Item & Canasta mínima & Canasta básica & Scenario 2 \\
\hline Maize $\left[\mathrm{kg} / \mathrm{cap}^{*} \mathrm{a}\right]$ & 110 & 110 & 96 \\
\hline Beans $[\mathrm{kg} / \mathrm{cap} * a]$ & 73 & 73 & 0 \\
\hline Sugar $[\mathrm{kg} / \mathrm{cap} * a]$ & 37 & 37 & 0 \\
\hline Rice $\left[\mathrm{kg} / \mathrm{cap}^{*} \mathrm{a}\right]$ & 37 & 37 & 0 \\
\hline $\operatorname{Milk}[l / c a p * a]$ & 0 & 0 & 89 \\
\hline Cheese $\left[\mathrm{kg} / \mathrm{cap}^{*} \mathrm{a}\right]$ & 0 & $8^{21}$ & $17^{22}$ \\
\hline Eggs [units/cap*a] & Autoconsumption (low) & 104 & 181 \\
\hline $\begin{array}{l}\text { Chicken } \\
{\left[\mathrm{kg} / \mathrm{cap}^{* a]}\right.}\end{array}$ & $\approx 0$ & 4 & 9 \\
\hline Pig meat $\left[\mathrm{kg} / \mathrm{cap}^{*} \mathrm{a}\right]$ & 0 & 2 & 14 \\
\hline Beef $\left[\mathrm{kg} / \mathrm{cap}^{*} \mathrm{a}\right]$ & 0 & 2 & 28 \\
\hline Oil $[l / c a p * a]$ & 2 & 2 & 0 \\
\hline Lard & 0 & 0 & Autoconsumption \\
\hline Fruit [rations/cap $* d]$ & Autoconsumption (low) & 2 & Autoconsumption \\
\hline $\begin{array}{l}\text { Vegetables } \\
{[\text { rations/cap*d] }}\end{array}$ & $\approx 0$ & 2 & Autoconsumption \\
\hline Clothes [unit/cap*a] & 1 top, 1 pair of pants & 1 top, 1 pair of pants & 1 top, 1 pair of pants \\
\hline Shoes [pair/cap*a] & 1 & 1 & 1 \\
\hline Health $[C \$ / f a m * a]$ & 1000 & 1000 & 1000 \\
\hline Health [US\$/fam*a] & 71 & 71 & 71 \\
\hline Education $[C \$ / f a m * a]$ & 900 & 900 & 900 \\
\hline Education [US\$/fam*a] & 64 & 64 & 64 \\
\hline
\end{tabular}

Table 4.3: Food consumption and expenditures for clothes, health and education for the minimum and the basic needs and for scenario 2. Only the most essential necessities plus basic health and education are covered by the canasta básica (for an all-including list see appendix E). (See section 4.1.2).

\footnotetext{
${ }^{21}$ Soft cheese

${ }^{22}$ Hard and soft cheese
} 


\subsection{Results Scenario 1}

\subsubsection{Population and Strata}

In scenario 1 , in 25 years $(\mathrm{t}=25 \mathrm{a})$ population more than doubles to 1047 families. This leads to a population density of 524 inhabitants $/ \mathrm{km}^{2}$, which roughly corresponds to Okinawa, Japan, a densely populated urban area. As land is divided among the offspring, land tenure per family diminishes for each stratum as depicted in Figure 4.1. In this graph, the names of the strata of the status quo have been maintained in order to omit confusion. Nevertheless, with one exception they do not correspond to the real stratum anymore as explained below. After 25 years, the average land holding of all farmers' strata is reduced to one third of the status quo. Consequently, there is a big shift in the proportion of families belonging to a certain stratum. While small farmers (status quo) remain, those who were medium farmers become part of the small farmers. The former big farmers turn into medium farmers. Landless farmers remain landless. Hence, $50 \%$ of the farmers' 534 families are landless, 45\% (471 families) are small farmers, and 5\% (52 families) are now medium farmers (Figure $4.2)$. 


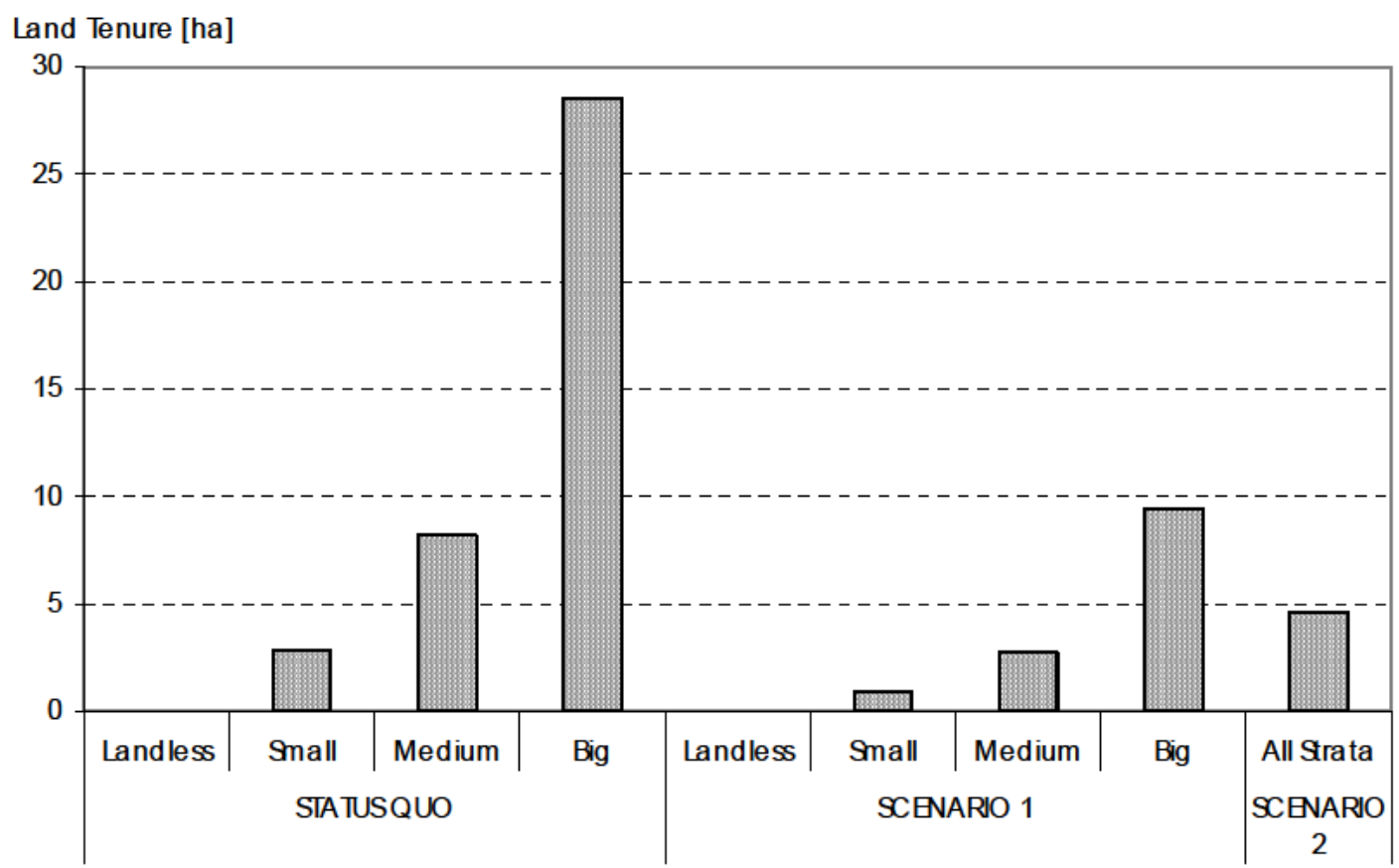

Figure 4.1: Land Tenure of the strata at status quo and for scenario 1 and 2. The strata's names of the status quo have been maintained for scenario 1 in order to omit confusion, although their real status does not necessarily correspond to the denomination anymore. While in scenario 1 all the strata see their land divided by three, in scenario 2 all inhabitants belong to the same strata.

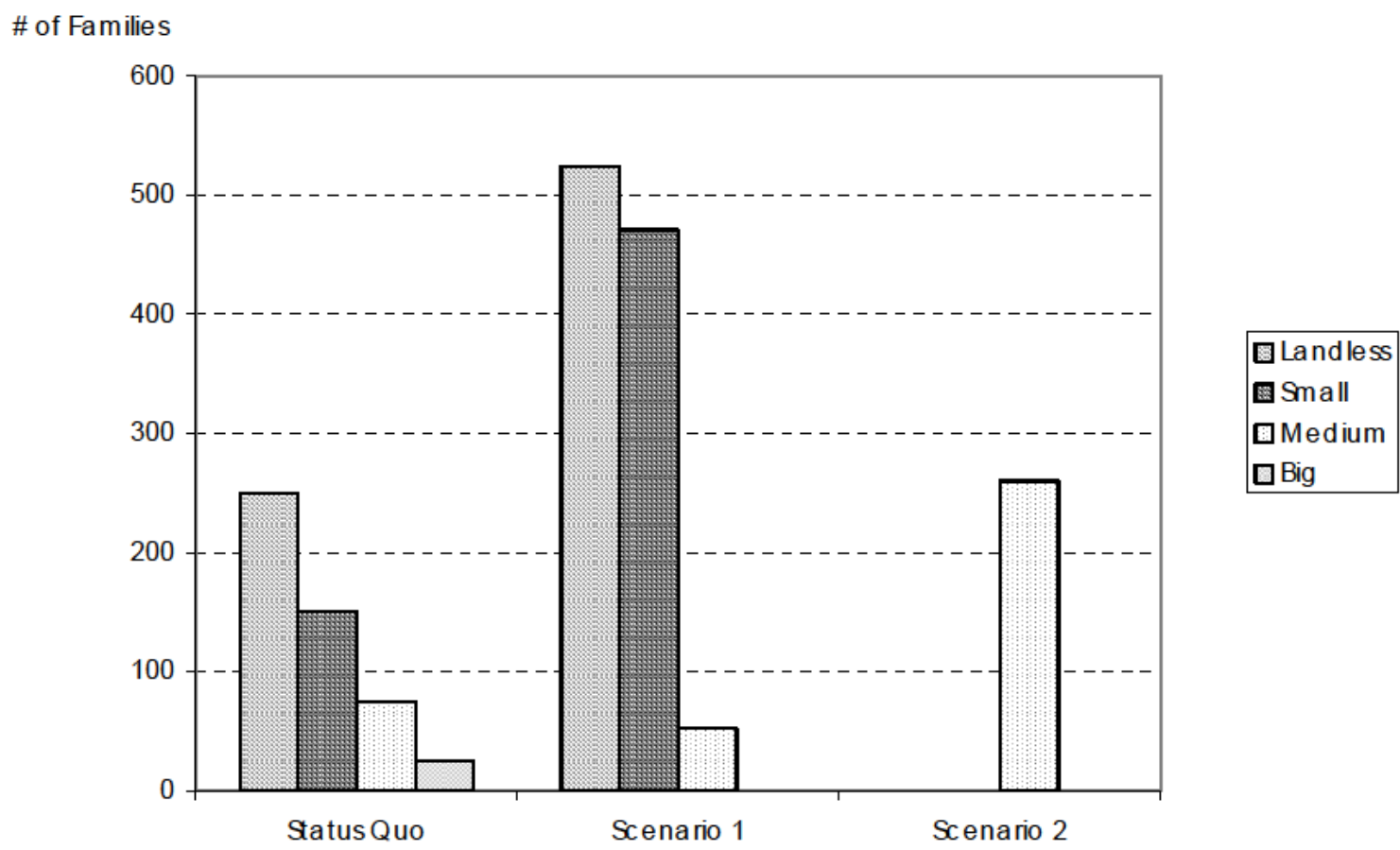

Figure 4.2: Shift in family numbers belonging to a certain stratum for both scenarios. In scenario 1 almost all families belong to the landless and small farmers' strata. In scenario 2 only medium farmers exist (see sections 4.2.1 and 4.3.1). 


\subsubsection{Land Use}

Regional land use changes as a result of smaller average holdings (Figure 4.3) and the subsequent changes of preferences. Whereas the staple area increases to three quarters of the total land, the one used for perennials shrinks to approximately one fourth. Thereof, $15 \%$ are pastures and about $10 \%$ coffee and natural forest.

Figure 4.4 depicts the strata's land use for the status quo and the scenarios. For scenario 1, due to the decrease of land tenure, agricultural activities focus on staple crops, as under the given circumstances farmers intend to cover primarily their basic needs. Hence, landless farmers with access to land will concentrate on staple production. So will small farmers, as their plot was reduced considerably in comparison to the status quo. Former medium farmers maintain a plot with coffee forest. For the former big farmers, which according to their land holding are now medium farmers, it is difficult to assess the land use. They own still quite large holdings of a size, which places them close to the stratum of big farmers. They are thus in a transition state, which had to be considered in their land use. Thus, medium farmers (scenario 1) use almost $40 \%$ of their land for pasture, $20 \%$ for coffee and natural forest and about $45 \%$ for staple production. They also own 2 cows each.
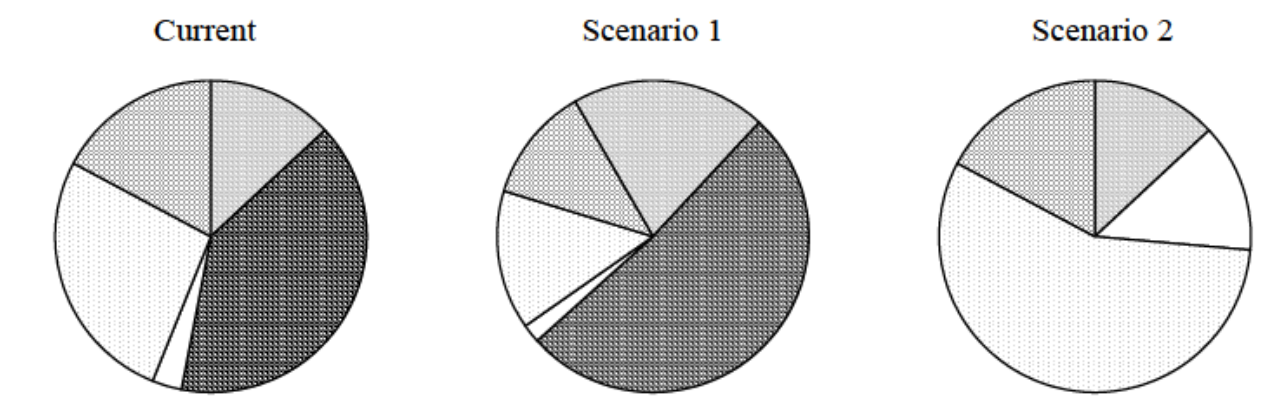

圈 Beans $\square$ Fallow

$\square$ Pasture

Coffee \& Forest

Maize

Figure 4.3: Regional Land Use currently and under scenario 1 and 2. Land used for staples increases in scenariol, while pastures, coffee and forest shrink. In scenario 2 the area used for pasture is biggest. No beans are cultivated. Land used for maize growing and forest remains about stable compared to the status quo (see sections 4.2.2 and 4.3.2). 


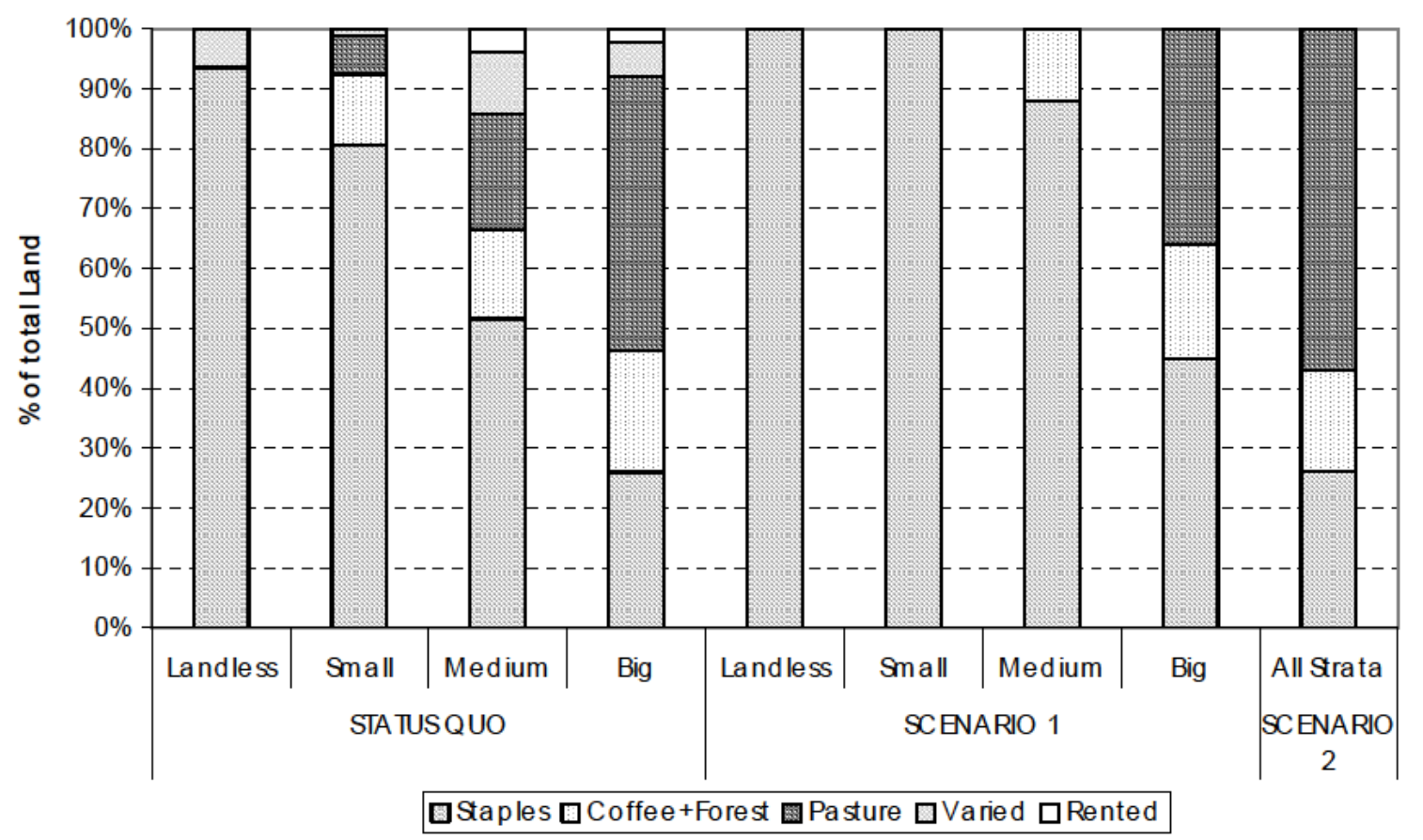

Figure 4.4: Land use of the different strata for both scenarios and the status quo. In the status quo, landless and small farmers mainly produce staples. Medium and big farmers also grow coffee, forest and pasture. In scenario 1, previous medium farmers have become smallholders. This is reflected in their land use. Former big farmers' land has shrunk too. Although formally part of the stratum "medium", they are actually in a transition stage. Thus, they still possess some cattle. In scenario 2 all farmer families own pasture, coffee \& forest and maize plots. (Strata's' names of the status quo were maintained for scenario 1 in order to omit confusion, although their real status does not necessarily correspond to the denomination).

\subsubsection{Nitrogen Metabolism}

In scenario 1 nitrogen fluxes per capita change considerably (Figure 4.5, Table 4.4). Smaller average fluxes indicate that many inhabitants of the region suffer from hunger. Perhaps the most striking figure is food autoconsumption, which is cut in half compared to the status quo - an indicator of the severe food shortage. Nevertheless, the process food production still dominates nitrogen metabolism. The amount of waste gases diminishes per capita, but increases in absolute terms. Nutrient mining has also decreased per capita. This results from reduced staple area per person. On a per hectare basis total nutrient mining increases by $7 \mathrm{~kg} / \mathrm{ha}$ (Table 4.4). The per capita firewood flux remains constant. However, on a regional level, due to the increase in population, firewood demand is elevated such that nitrogen mining out of the process coffee and forest per ha has almost tripled (factor 2.8). 


\begin{tabular}{|c|c|c|c|c|c|c|c|c|}
\hline \multirow[t]{2}{*}{ Scenario } & \multicolumn{2}{|l|}{ Staples } & \multicolumn{2}{|c|}{ Animal Production } & \multicolumn{2}{|c|}{ Coffee \& Forest } & \multirow{2}{*}{$\begin{array}{l}\text { Total } \\
\text { mining } \\
{[\mathrm{kg} / \mathrm{ha}]} \\
\end{array}$} & nutrient \\
\hline & [kg/ha] & [kg/cap] & {$[\mathrm{kg} / \mathrm{ha}]$} & {$[\mathrm{kg} / \mathrm{cap}]$} & [kg/ha] & [kg/cap] & & [kg/cap] \\
\hline Status Quo & -31 & -7 & -9 & -1 & -66 & -5 & -31 & -13 \\
\hline Scenario 1 & -23 & -3 & 2 & 0 & -188 & -4 & -39 & -8 \\
\hline Scenario 2 & 15 & 3 & -3.5 & -2 & -35 & -4 & -4 & -3 \\
\hline
\end{tabular}

Table 4.4: Nitrogen mining on a regional scale for the status quo and the two scenarios. On a regional scale most nitrogen is mined from coffee \& forest plots, as families without their own energy source cut the firewood on alien land with or without permission. Mining from staple plots decreases with scenario 1 , but people suffer from hunger. In scenario 2 it can be diminished by restraining from burning and bean growing (see section 4.2.3 and 4.3.3).

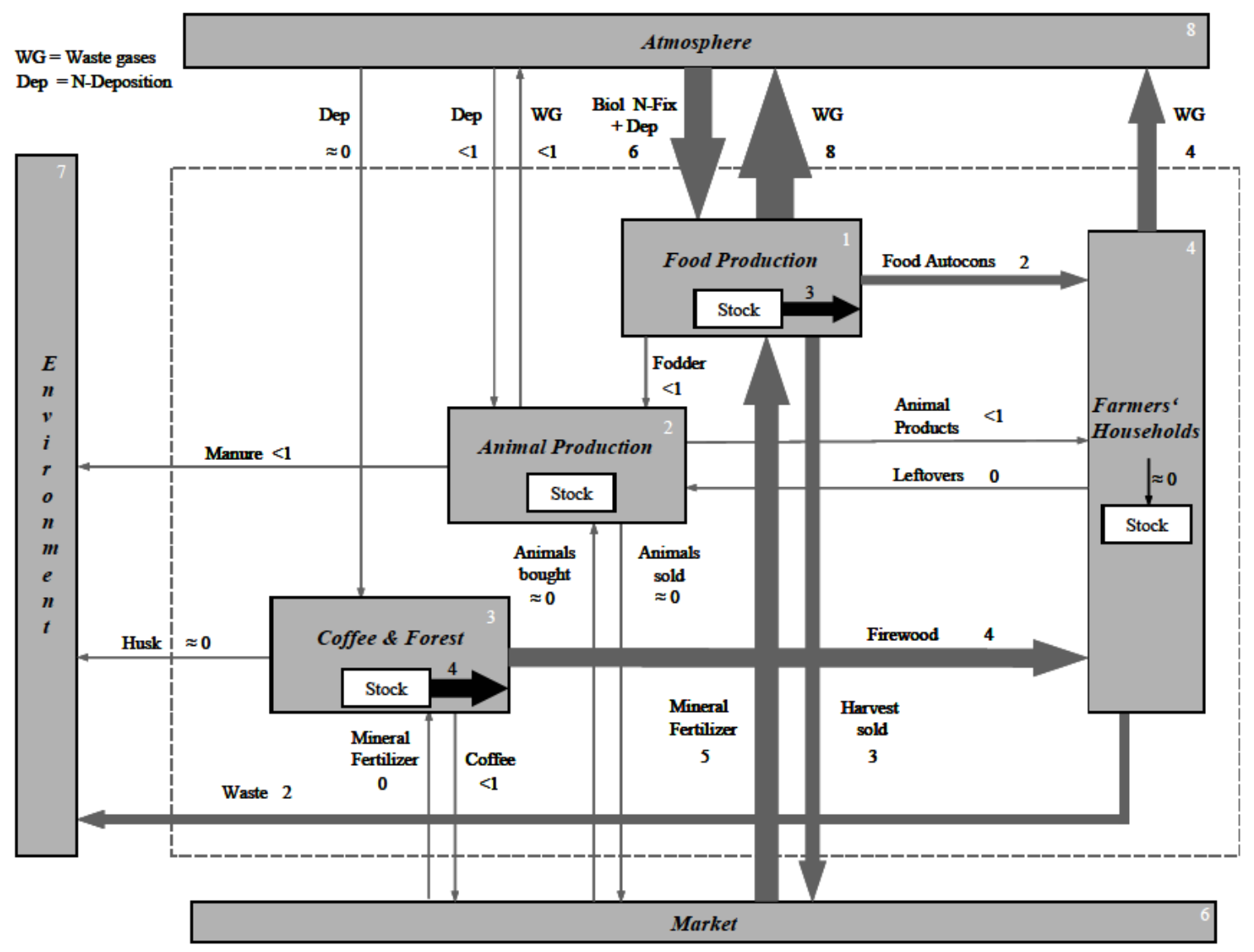

Figure 4.5: Nitrogen fluxes per cap (kg/cap*a) for scenario 1. Nitrogen fluxes per capita have mostly remained stable or decreased, as not enough food can be produced anymore and hunger prevails. Mining out of coffee \& forest has increased by a factor close to 3 (see section 4.2.3). 


\subsubsection{Self-Sufficiency}

The regional DSS of maize has dropped below $100 \%$ in scenario 1 (Figure 3.13):

With an average harvest the local maize production covers about $80 \%$ of the need, while for a bad harvest this ratio drops to roughly $40 \%$. For beans the average harvest generates a surplus of $70 \%$, while in a bad year auto-sufficiency is not reached, as only $75 \%$ of the need is covered. Nevertheless, it has to be borne in mind that as a result of the severe nutrient mining average yields drop considerably in the course of 25 years. Thus, actual self-sufficiency is lower than the one calculated here.

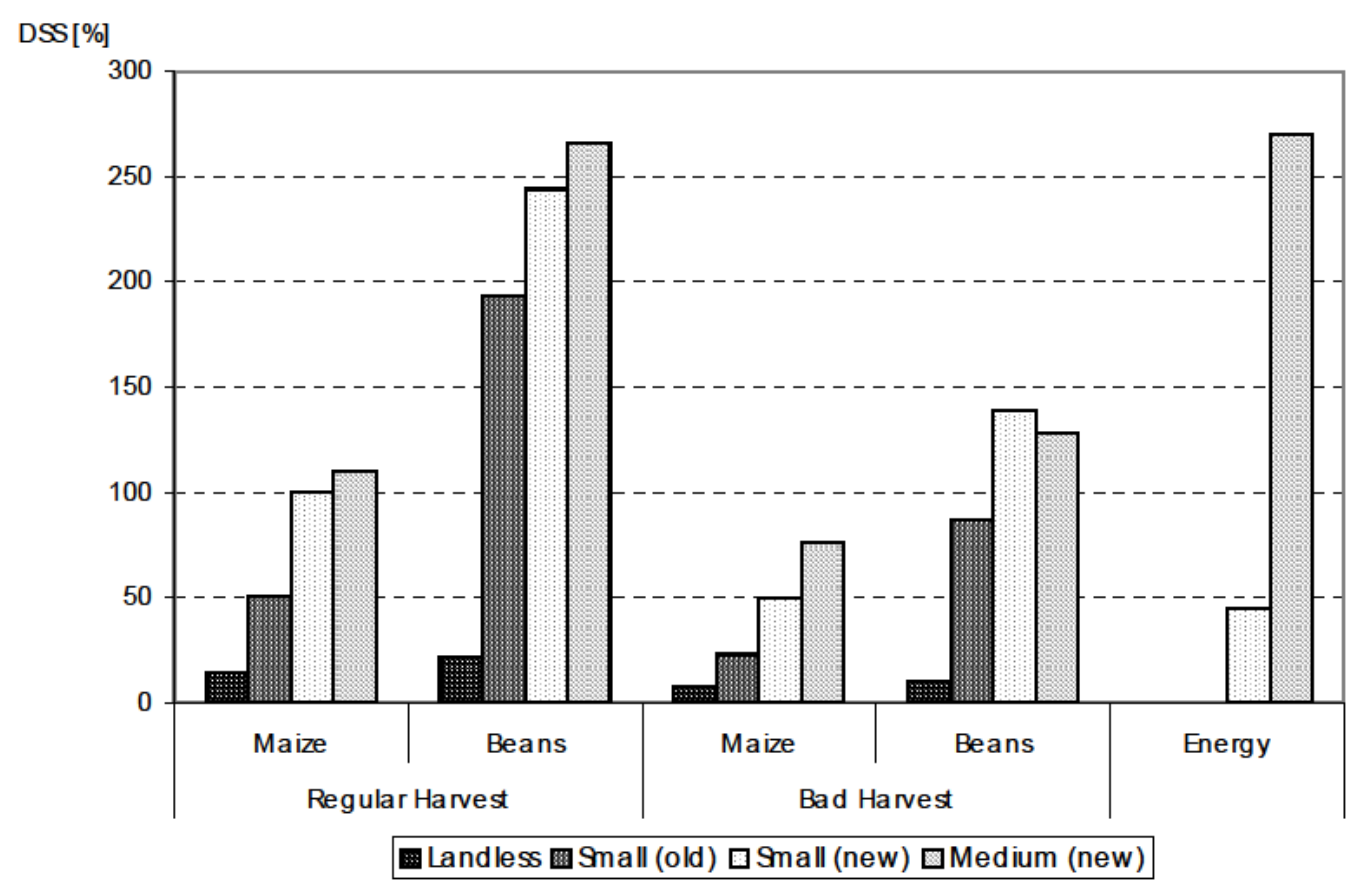

Figure 4.6: Degree of self-sufficiency for farmers' strata in scenario 1. With an average harvest, only the new small (former medium) and the new medium (former big) farmers can cover their needs of maize. For a bad harvest, no strata produces enough maize for self-supply. In an average year only landless farmers cannot cover their bean need, while for a bad year only the new small and the new medium farmers can. Energy production is concentrated almost entirely in the hands of the few medium farmers, which are the only ones to cover their energy demand. (new small =former medium; new medium =former big). (See section 4.2.4).

Theoretically, the region could still produce enough food for its people by expanding the staple area and raising the share of land used for maize production. Nevertheless, this would not benefit the landowners. Maize does not pay well on the market and the production of beans is prone to risks like drought and wetness. So farmers owning 
enough land try to diversify to cash crops like coffee and dairy products. They do not maintain a big staple area for the sake of giving work to the landless, if it is not convenient for them. This leads to a severe crisis in the provision of food for the landless families: If the land available for sharecropping is distributed among all landless peasants, each family covers about $15 \%$ of their maize needs in a good year, while for bad harvests this figure drops to less than $10 \%$. For beans, the DSS is at about $20 \%$ for a regular year $10 \%$ in a bad one. Accordingly, the DSSs have dropped for all other farmers' strata. Small farmers (small farmer in status quo) cover $50 \%$ of their maize need in a regular harvest, while for a bad harvest this figure drops to roughly $20 \%$. For the bean harvest the respective figures are $190 \%$ and $90 \%$. The rest of the small farmers, which used to be medium sized (status quo), just cover their need of maize with an average and only half with a bad yield. For beans these figures amount to $240 \%$ and $140 \%$ respectively. The medium farmers of scenario 1 , big farmers in the status quo, reach a $\mathrm{DSS}_{\mathrm{M}}$ of $140 \%$ in a regular year.

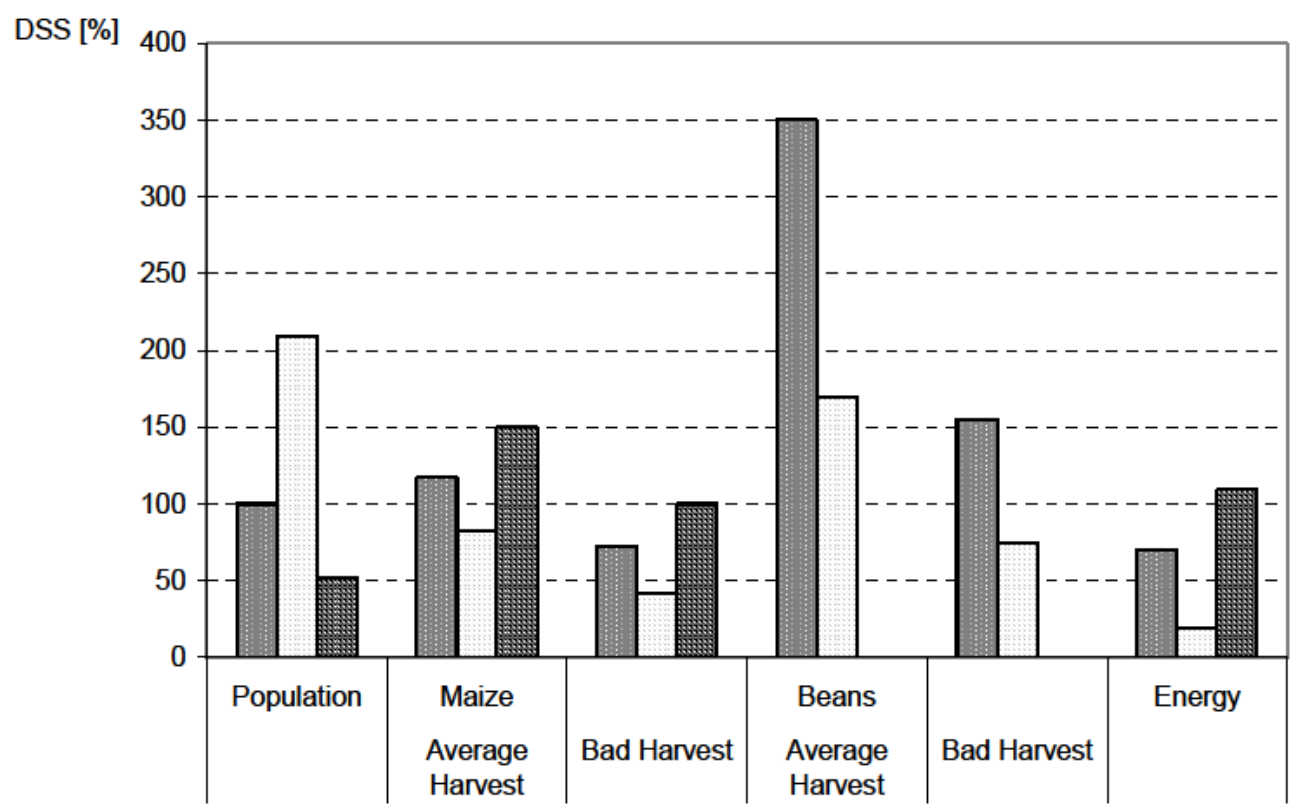

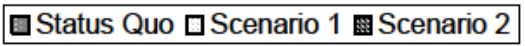

Figure 4.7: Degree of self-sufficiency (in DSS \%) and population ratio (in \%) for the status quo, scenario 1 and scenario 2: In scenario 1, the region is only self-sufficient for beans if the harvest is at least average. The key problem is energy, as only a minority of the inhabitants has access to sufficiently firewood. In scenario 2, self-supply of maize is reached in average and bad years. There is enough firewood for the families. Beans are not produced anymore (see sections 4.2.4 and 4.3.4). 
After a bad harvest they just about cover their maize need. The DSS for beans amounts to $340 \%$ in a regular and to $170 \%$ in a bad year. As regards the $\mathrm{DSS}_{\mathrm{E}}$, for a sustainable system only about $20 \%$ of the regional energy needs are covered. The firewood derives from the natural and the coffee forest, which are owned by $20 \%$ of the farmers, namely the former medium and big farmers. Those cover their needs at $45 \%$ and $270 \%$ respectively. Thus, as only one fourth can cover its own energy needs, energy is not freely available anymore. This makes the economic situation for people even more difficult. Although this inevitably leads to increased efficiency in the use of firewood, it may also cause a change of the menu from energy consuming staples to other foodstuffs. Thus, energy shortage can lead away from a balanced diet. Tensions and social conflict are other probable consequences if there is no alternative cheap energy source available. In view of this desperate situation it can be assumed that people will search for alternatives outside of the area.

\subsubsection{Economy}

If we look at proportions of strata in scenario 1, there is actually a heavy imbalance between farmers who own enough land for sharecropping or renting and people needing land. Working possibilities in agriculture have declined too, due to diminished average landholdings of tenants and bigger landless population, which increases the competition on the regional labor market. Only $40 \%$ of the grains the landless need for survival can be earned in agriculture through sharecropping and dayto-day laboring. As a consequence, people are suffering from hunger. This is illustrated by the figures of the coverage of the basic needs (Figure 4.8).

By sharecropping alone, landless peasants cannot even harvest their basic grain needs. They only cover $5 \%$ of their canasta básica, and about $10 \%$ of their canasta mínima (Figure 4.9). Small farmers (status quo) can buy roughly a third of their basic needs and roughly $80 \%$ of their minimum needs, while purchase power of the former medium farmer is reduced to about $70 \%$ of the canasta básica and $170 \%$ of the canasta mínima. The former big farmer covers $185 \%$ and $431 \%$ of these expenses respectively. 


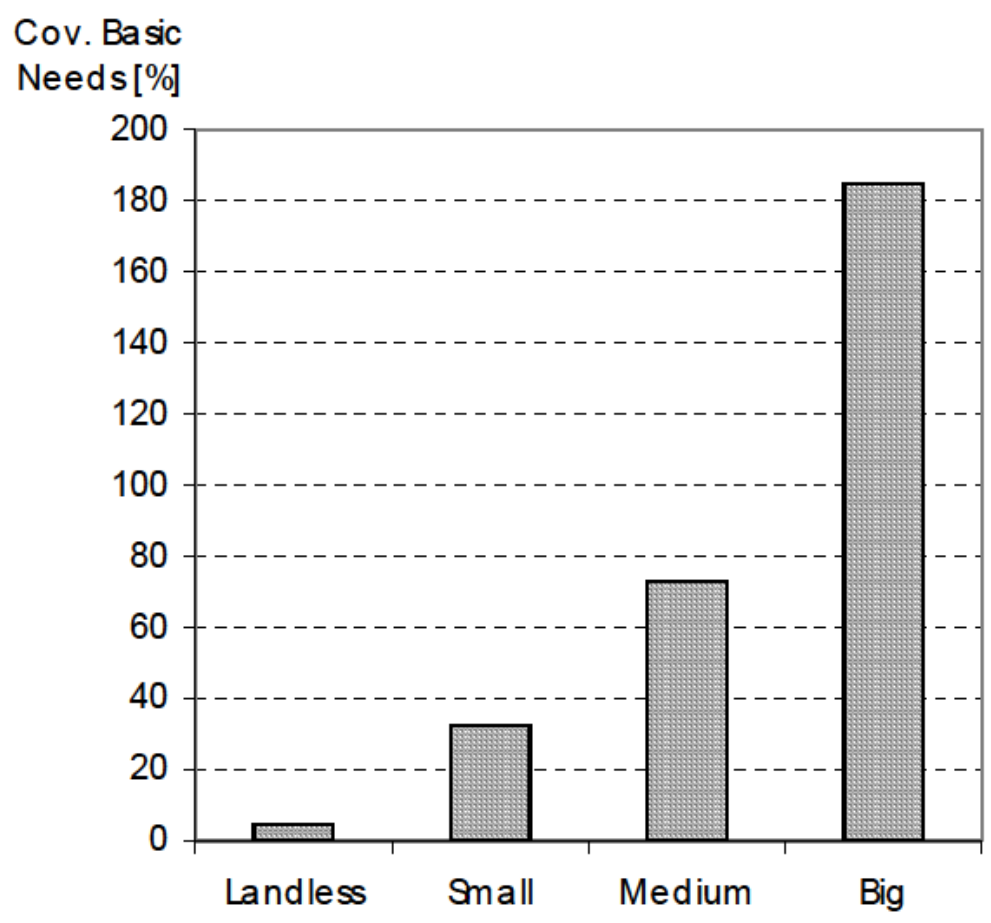

Figure 4.8: Coverage of the basic needs in scenario 1 for the different strata. The landless farmers cannot even produce their need of staples anymore, which is reflected in their extremely low coverage of the basic needs. The small and former medium farmers cannot cover the basic needs either. Only the former big farmers produce almost twice the costs of the canasta básica (see section 4.2.5).

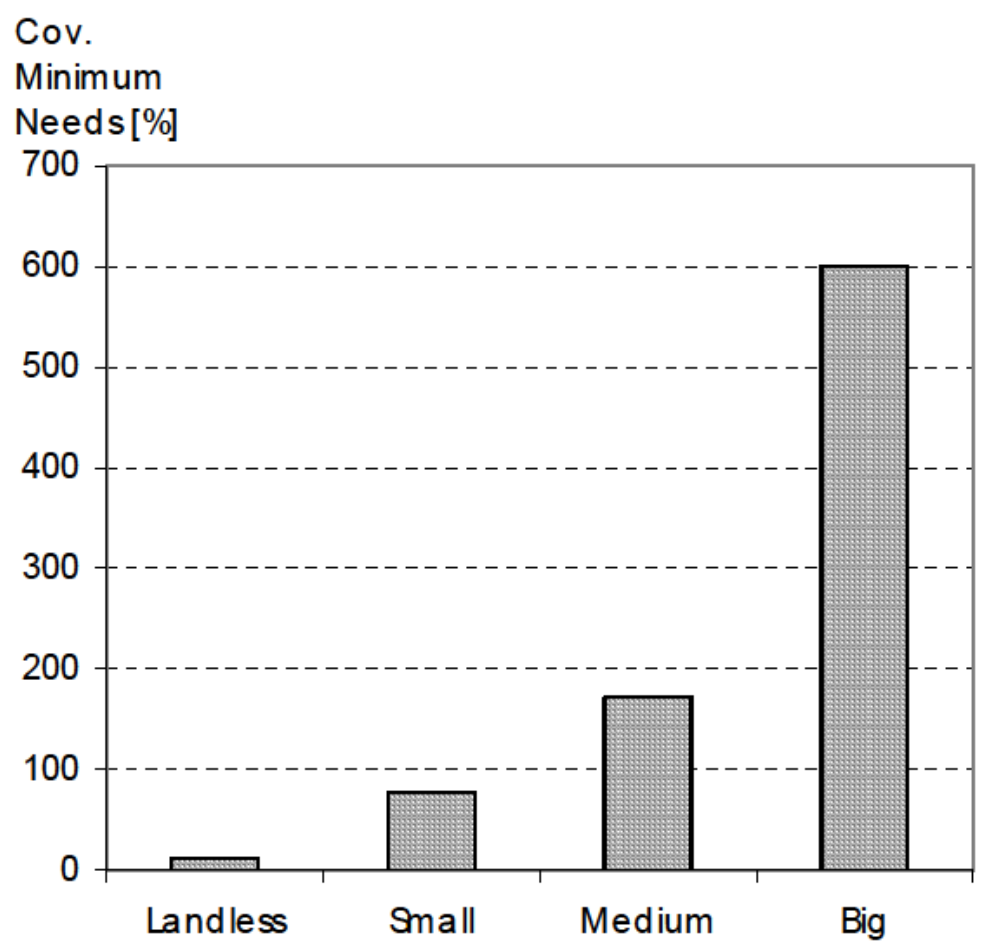

Figure 4.9: Coverage of the minimum needs in scenario 1 for the different strata. Only the former medium and big farmers are still able to produce the minimum needs and thus the calorie requirements of their families (see section 4.2.5). 
In order for all the families to be able to meet their basic needs, employment for almost 2000 persons has to be generated for the inhabitants of Susulí alone. Each landless family needs 2.4 fulltime jobs, while small farmers need 1.7 (status quo) and 0.7 (former medium) per family. If all families should meet the minimum needs, 600 employment opportunities have to be created - one for each landless family and 0.25 for small farmers (status quo). Thus, within one generation's lifetime a Hinterland offering jobs is indispensable for scenario 1 , as regional agriculture will not provide them.

\subsection{Results Scenario 2}

\subsubsection{Population and Strata}

In scenario 2 population shrinks to 260 families, about half of the current population. This corresponds to a population density of 130 inhabitants $/ \mathrm{km}^{2}$. As land resources are distributed equally among the population (Figure 4.1), all of the families become medium farmers. No other stratum exists anymore (Figure 4.2).

\subsubsection{Land Use}

The area used for growing maize has remained at the level of the status quo. As with primera the amount of maize needed is produced for the entire year, in postrera the land is free for improved fallow, beans for export or fodder production to increase milk output of the cows. More than half of the regional land resources are used for pasture, while the coffee and natural forest area remains constant at almost $20 \%$ (Figure 4.3). All the families own the same three plots: one for maize growing (1.2ha), one pasture plot (2.6ha) and one coffee $\&$ forest plot (0.8ha). As the land use is alike for all families, the proportions correspond to those of the region (Figure 4.4). The families hold almost four cows (3.75), three pigs, eleven hens and some chicken each. 


\subsubsection{Nitrogen Metabolism}

In scenario 2, the process food production still dominates nitrogen dynamics. However, nitrogen mining could be stopped for this process and there is even a slight accumulation of nitrogen (Table 4.4, Figure 4.10). This is due to two main reasons: on one hand the abstention from burning crop residues, on the other hand the increase of the mineral fertilizer import. The former is a consequence of the increased livestock density, as crop residues are now used as cattle feed. The latter occurs due to a shift of all the families to the stratum of the medium farmers according to their new land holding. These use considerably more fertilizer than small producers.

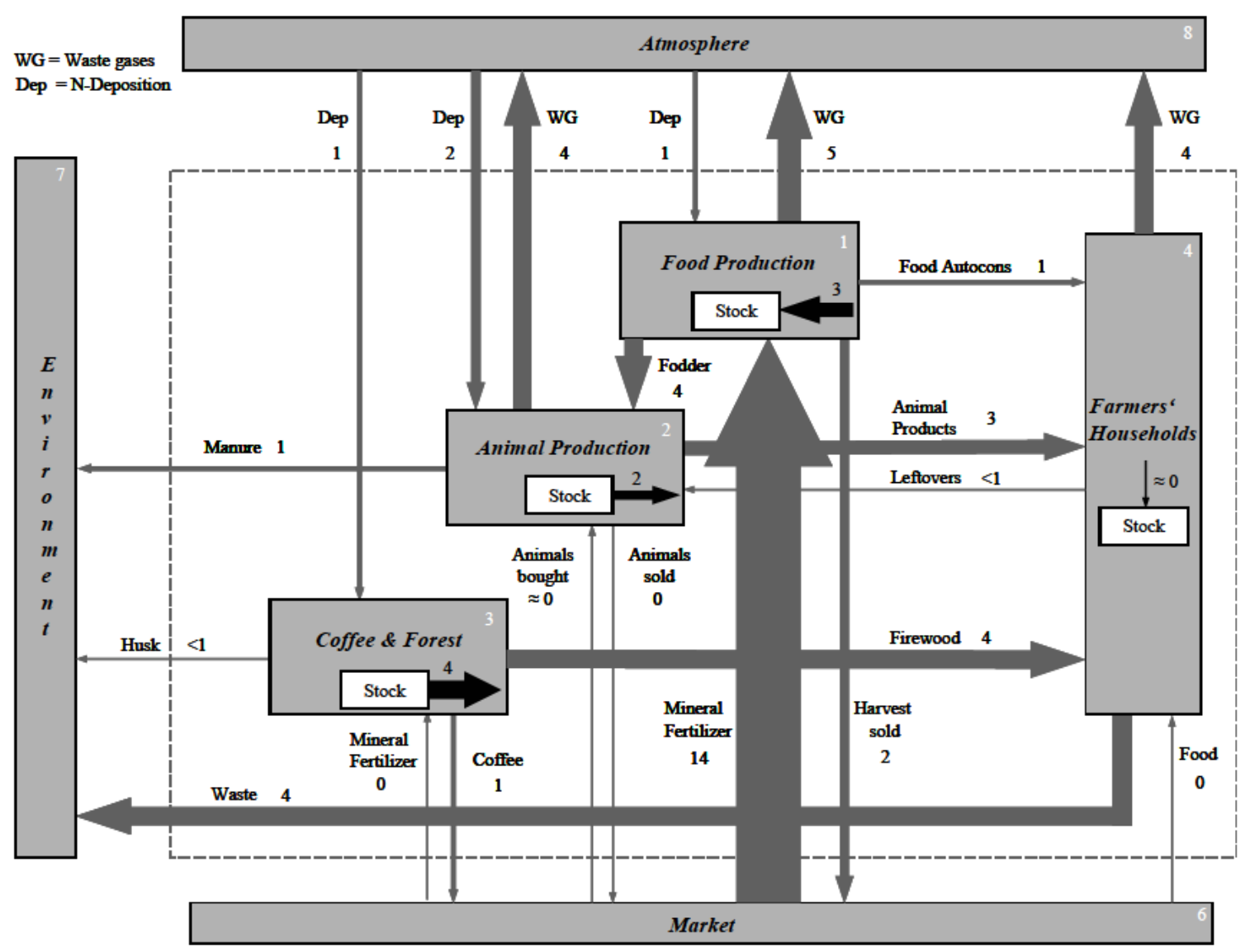

Figure 4.10: Nitrogen fluxes per cap (kg/cap*a) for scenario 2. Nitrogen mining could be stopped for food production, but still persists for coffee \& forest plots and possibly pastures. The flux autoconsumption has been reduced, while fodder has increased fourfold (See section 4.3.3). 
Another important change occurred for the process animal production: While under the status quo this process and its corresponding fluxes were insignificant in comparison to the whole system, under scenario 2 these fluxes have become more relevant. The most prominent change is the substitution of the main nitrogen source for farmers' families. While for the status quo this was the process food production with $4 \mathrm{~kg} \mathrm{~N} / \mathrm{cap}^{*} \mathrm{a}$, and animal production was irrelevant with a supply of $<1 \mathrm{~kg}$ $\mathrm{N} /$ cap*a $^{*}$, for scenario 2 the opposite is the case. Staple production is still important, but now mainly as a fodder source.

While the flux autoconsumption has been reduced to one fourth of the status quo, fodder has increased fourfold and is now six times bigger than the flux autoconsumption. Manure from pigs and chicken, a potential fertilizer source, has also increased. Yet, the nitrogen flux of household waste has remained the same. Noteworthy is the apparent slight nitrogen mining from pastures in scenario 2 . Although the confidence interval is too big to make a clear statement, it may indicate that on the long run pastures are overgrazed and that therefore the maximum adequate stocking rate of 1 animal per 0.7 ha mentioned by farmers may be too high for this extensive system. Thus, a lower maximum stocking rate may have to be considered . The fact that nitrogen mining from the coffee and forest plots has only been reduced to $4 \mathrm{~kg} \mathrm{~N} / \mathrm{cap}^{*}$ a is striking. Therefore, although the system is seemingly in a steady state, nitrogen mining still occurs.

\subsubsection{Self-Sufficiency}

When calculating the maximum number of families which could live in Susulí under scenario 2, self-sufficiency was given priority. Thus, maize yield of a bad harvest was set at $100 \%$ of the family's need for food and fodder in order to calculate the land needed for the cultivation of maize. This means that in good harvests a surplus of $50 \%$ of maize is produced (Figure 4.7). The protein supply on the other hand does not directly depend on harvests, but is rather linked to three factors central to animal husbandry: water availability, nutrition and hygiene (Webster and Wilson, 1998). It was presumed to be relatively stable. Furthermore, as human nutrition in this scenario relies heavily on animal products, which are high value products, there is a lot of 
room for action for exchanging these against e.g. plant derived products. For bad years, a DSS for maize and protein supply of $100 \%$ is supposed while a surplus is obtained with good yields. The energy supply is covered with firewood from each family's own coffee forest plot. The $\mathrm{DSS}_{\mathrm{E}}$ for a system in equilibrium lies around $110 \%$.

\subsubsection{Economy}

Scenario 2 was designed for autosupply. As the canasta básica also includes basic education and medicine, it does not come as a surprise that farmers cover their canasta básica only to $75 \%$ (Figure 4.11 ).

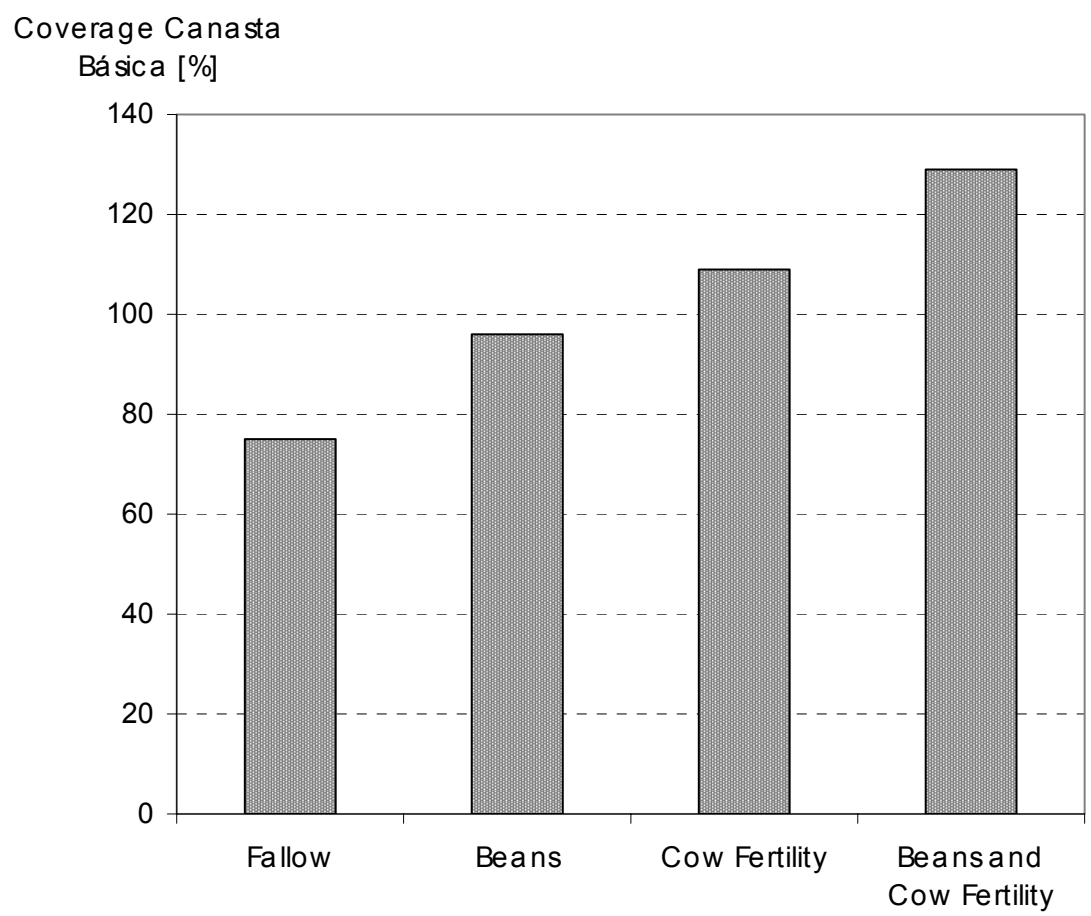

Figure 4.11: Coverage of the basic needs in Scenario 2. The higher-value basic needs can only be covered if production is complemented with increased cow fertility, and possibly beans for sale (see section 4.3.5).

This means that in order to meet all the basic needs of the families either population density has to be lower or one member of the farmers' families has to find a fulltime job for nine months a year in order to close the gap. Nevertheless, other possibilities exist.

Thus, beside the option mentioned, other three have been developed: 
a) Staple land is left under non-improved fallow in postrera

b) Beans are grown on the staple land in postrera and are sold

c) The fertility of cows is raised to $100 \%$

d) Combination of b) and c)

If beans are cultivated and sold, the basic needs can just about be covered. Yet, nitrogen mining would rise. The same problem arises with the increase of the fertility ratio of cows by $50 \%$, which could be reached e.g. with improved nutrition through fodder production on the maize plot in postrera. There are various dual-purpose leguminous crops which can be used as improved fallow and livestock fodder. If farmers manage to combine b) and c), for instance through fodder supply by an agrisilviculture system, the canasta básica can be covered by $130 \%$.

\subsection{Discussion of Scenarios}

It is well known that a crucial constraint to sustainability is population dynamics. Others are tightly linked with it. In scenario 1 the steady growth rate of $3 \%{ }^{23}$ leads to a duplication of the population in less than 25 years. The pressure on land resources increases considerably. As a result, more land is used for staple production and the forest and the pasture areas shrink, which makes farming systems less crisis resistant. Furthermore, the region is far from being self-sufficient for energy. Maize production cannot keep up with the demand, even in an average year, while for beans the gap arises only for bad years. Yet, most families - except for the former big farmer cannot earn their living with agriculture anymore. Many suffer from hunger.

Although the Malthusian perspective of scenario 1 is widely discussed and various examples where farmers begin to intensify and adapt their farming systems with rising population exist (Boserup, 1965; Tiffen et al, 1994), the factor time is often neglected. In most of these examples adaptation has occurred in decades, if not centuries. For areas like our study region, time is running out and no important adaptations of the management can be observed. Although this is partly due to the (economic)

\footnotetext{
${ }^{23}$ The actual national population growth rate in Nicaragua is at $2.7 \%$ (UNDP, 2000)
} 
circumstances, as these are not prone to change soon, the probability that modifications are to be expected in the near future is small.

In scenario 2 half of the families emigrate. The land use changes considerably, as more than half of it is pasture. N-mining can be stopped for staples, nevertheless, there is a slight mining from pastures and a considerable one from forests. As scenario 2 is a threshold scenario, its high-value canasta básica can only be covered if farmers either raise the fertility of cows or produce additional produce.

Although it is theoretically possible to change production structures in the study region, there are several important preconditions which have to be met:

- A Hinterland which provides working possibilities for the surplus population

- Knowledge transfer about cattle raising to the farmers

- Credits

- A good market environment for the farm products

- Necessary infrastructure

Without technological changes, like e.g. the growing of fodder crops or the increase of cow fertility, in our study region moving up the food chain is only possible if population is reduced drastically and a minimum access to land is guaranteed for each family. As the "surplus" inhabitants need another basis to make their living off, the condition to this migration is a Hinterland, which provides work.

Furthermore, the farmers need to acquire the necessary knowledge about breeding, raising and maintaining livestock. Hygiene measures and good nutrition for instance are key parameters in animal husbandry. Thus, in some Nicaraguan regions farmers accomplished substantial yield improvements by introducing measures like the supply of minerals to cattle, disinfection of the umbilicus of new-born calves, construction of wells, improvement of the rotation of pastures and alternative fodder systems for the dry period (Artola, 1998).

Another problem is the high investment costs of changing a production system. Thus, for a system based on livestock, considerable investments have to be made for fencing 
and the purchase of the animals. Therefore favorable long-term credits have to be available, which currently are lacking.

Moreover, if goods are produced for the market, they should ideally obtain a reasonable, stable price. Presently, on the Nicaraguan national market there is a demand for milk (and e.g. also vegetables), part of which has to be imported from abroad. Yet, if the economic crisis in Nicaragua persists, the demand for animal products is likely to drop. As poor people spend on average $60-70 \%$ of their income on food, the steady increase of prices has a direct effect on their diet. Foodstuffs are reduced to stomach-filling staples. Nevertheless, there are marketing possibilities for milk products in nearby El Salvador (Artola, 1998). Yet, for the supply of the domestic and the foreign market considerable improvements to infrastructure (e.g. roads, cheese and powder milk processing plants) have to be made. For Peru it could be shown that growth in urban demand for dairy products can strongly benefit smallscale highland farmers if the necessary infrastructure is provided by the government (Bernet et al., 2001). Moreover, in Nicaragua there are by-products of animal husbandry like leather, which are not merchandised by farmers, although the local shoe manufacturers have to import the raw material from abroad. Improved care for the animals is a precondition though, as currently Nicaraguan leather quality is not high enough for the manufacturers.

It has to be borne in mind that for each farming system a delicate balance exists between economic and ecological factors. Hence, if farmers want to produce a surplus with the system of scenario 2, they have to increase the fertility of cattle and grow beans for sale in postrera. Yet, stocking rates cannot surmount a certain threshold because of overgrazing and asymmetrical nutrient balances. On the other hand, the staple system is highly vulnerable to nutrient mining. Especially growing beans causes a nitrogen loss under the current farm management. While considering changes in the production systems, it has to be taken into account that in scenario 2 and more land is used per capita to produce the necessary foodstuffs. The impact on land use is especially pronounced due to the extensive animal husbandry system predominant in Nicaragua. Under these conditions, it is highly questionable whether it makes sense to substitute plant by animal protein. Propositions to enhance the efficiency of animal production include agro forestry systems (Artola, 1998). 



\section{DYNAMIC MODELING OF FARMING SYSTEMS}

\subsection{Dynamic Model Approach}

\subsubsection{The need for a dynamic model}

In a dynamic model, variables and parameters are time dependent, while in the quasistationary model only stocks depend linearly on time (Figure 5.1).

(a)

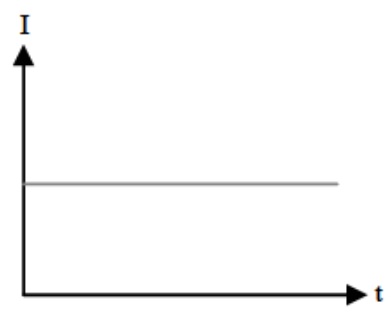

(b)

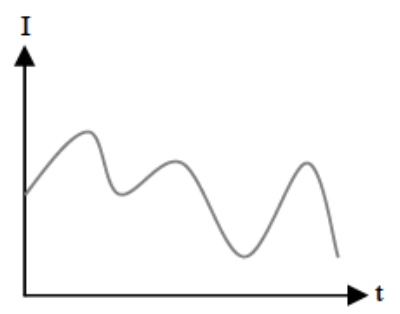

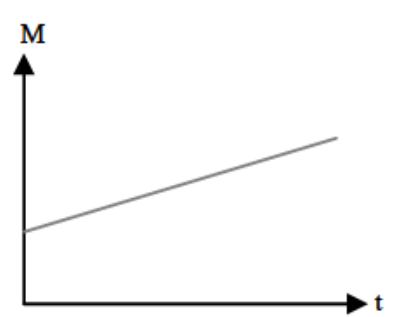

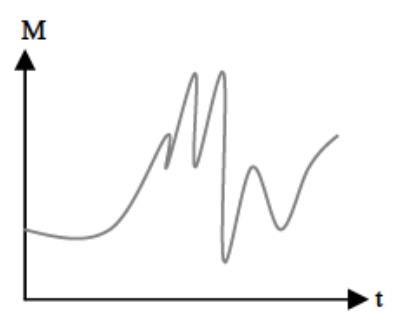

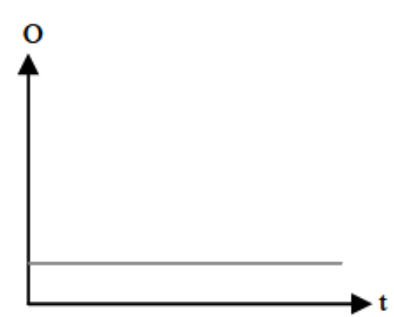

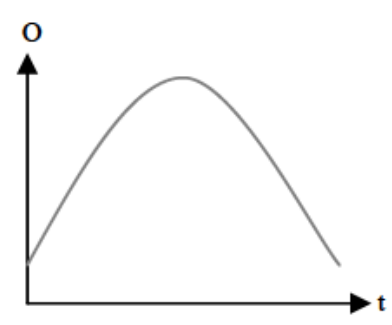

Figure 5.1: Quasi-stationary (a) and dynamic (b) models. While in quasi-stationary models only stocks depend linearly on time (a), in dynamic models every variable and parameter can be timedependent (b). This facilitates new approaches, where e.g. agents' decisions taken according to the state of a variable can be modeled. 
The real world is a dynamic system. Not average, but actual figures are crucial for survival, life quality and decisions taken by actors. In an agricultural system the latter is particularly complex. Thus, the utilization of resources by different actors may depend on time and the actual state of the stock, while this in turn depends again on decisions taken some time before. E.g. in a system where food is produced for autoconsumption, humans adapt their consumption to staple stocks, considering furthermore the time left until those are replenished again. Yet, the size of the stock depends on how much has been eaten before and thus on previously taken decisions. Hence, as people tend to eat more when stocks are full, seasonal patterns of food consumption are of great importance. In the study region hunger is mostly a seasonal but widespread phenomenon, as people's storehouses are empty and there is no money for buying food. While the quasi-stationary model indicates that there is not enough food, the dynamic model further points out when and may sometimes even hint possible causes.

A further crucial fact is harvest oscillations, which affect income and food security. A dynamic model makes it possible to analyze this factor, while in the quasi-stationary model harvest averages had to be assumed. Particularly in the non-mechanized agriculture of developing countries the offer and demand of workforce is also subject to great seasonal variations. Temporary labor shortages can have severe implications on e.g. crop choice and land use patterns. Moreover, while in the quasi-stationary model animal stocks were all considered to be in a dynamic equilibrium, the timedependent model shows the building up of the animal population and oscillations or collapses caused by diseases. Fluctuations of the chicken population can be considerable, which affects the maize reserves and thus has an impact on maize available for human consumption. Last but not least, a dynamic model may help to explain why a certain stratum manages the farm the way it does. It may hence help to track down the rationale of some land use patterns and farmers' actions and permit to perceive the risks which the farmers are exposed to. 


\subsubsection{Goal of setting up a dynamic model}

With the quasi-stationary analysis, several questions have remained unanswered. The dynamic model aims at responding to the following three:

1. How can human strategies (e.g. stock management, animal population control, crop mix) for a given system be modeled? What impact do they have on the system?

2. What are the crucial regulation factors of the system?

3. What is the importance of seasonal oscillations of resource availability in an agrarian region of a developing country?

\subsection{Description of the Model}

Generally spoken, the model describes the metabolism of natural renewable resources in an agricultural region. Its state and development are mainly influenced by the local environmental conditions on one, and the decisions taken by agents involved in their use on the other hand.

\subsubsection{System Analysis}

The dynamic model for individual farms depicted in Figure 5.2 is based on the system used for the quasi-stationary model and adjusted to the requirements of dynamic modeling. Thus, the basic processes of the quasi-stationary model have been mostly adopted. There have been the following changes:

a) The process coffee \& forest was divided into the two processes coffee and forest. While the former includes only the coffee beans, the latter stands for trees and shrubs, independently on where they stand (e.g. in a coffee growing area as shade trees).

b) For maize, beans and coffee separate storage processes were introduced. Thus, the entire harvest is transported to the storage process and distributed further 
from there, while in the quasi-stationary model the distribution "takes place on the field".

If necessary, the processes of the dynamic model were subdivided into different subsystems for calculation. Hence, the process animal production consists of five subsystems, namely chicken, pigs, cows, horses and grass. Each of them is computed independently. Thus, subsystems can be inactivated (e.g. for small farms the subsystems cows, horses, grass and pigs). The commodity fluxes were based on the indicator "energy". Hence, the nitrogen specific ones like N-fixation and deposition were eliminated. Furthermore, new, non-commodity fluxes, namely workforce, have been introduced. In Figure 5.2 the fluxes have been numbered for easier overview, except for workforce, which is represented by a grey arrow. Fluxes which are foreseen in the model, but are currently not relevant in the study region, are represented by a dot and dash line. Flux number 1 stands for fertilizer input (into coffee, beans, maize and grass production), while flux number 2 depicts animals purchased. Flux number 3 represents harvest and number 4 seeds. Number 5 is the share of the harvest sold and number 6 animals and animal products consumed by the household. Number 7 represents firewood used for cooking, while number 8 stands for the food purchased (rice, sugar and oil). Number 9 depicts the consumption fluxes of maize, beans and coffee from the own farm, while 10 corresponds to fodder maize. Stocks exist for all subsystems, respectively processes, except for the household. The modeling approach for these subsystems is introduced in the following sections. 


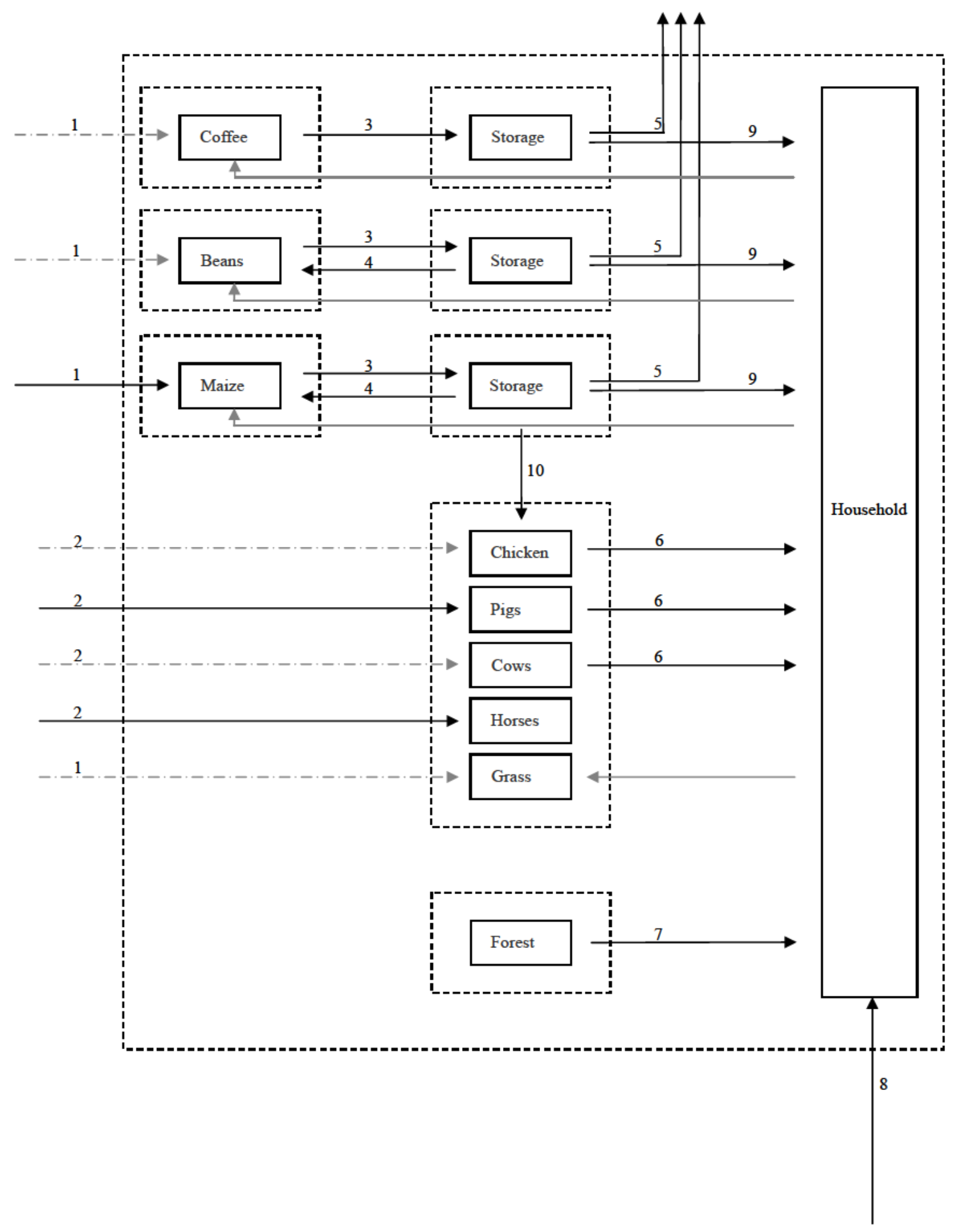

Figure 5.2: System of the Dynamic Model. The system was based on the one used for the quasistationary analysis. For maize, coffee and beans, a storage process was additionally introduced. 1: Fertilizer input, 2: Animals purchase, 3: Harvest, 4: Seeds, 5: Harvest sold, 6:Animals and animal products of autoconsumption, 7: Firewood, 8: Purchased foodstuffs, 9: Staple and coffee autoconsumption, 10: Fodder. Dash-and-dot lines indicate that the flux, although foreseen in the model, is currently not relevant in the study region. Workforce is represented by a grey arrow. 


\subsubsection{Model approach and calibration}

As we have seen in the previous chapters, resource growth and use largely determine the resource metabolism of an agricultural region. Hence, two groups of subsystems were introduced for dynamic modeling:

a) Subsystems regulated by biological growth patterns

b) Subsystems regulated by agents' decision patterns

\subsubsection{Subsystems regulated by biological growth patterns}

\subsection{The logistic growth function}

As early as 1837 Verhulst showed that biological systems can be described by logistic growth functions. Thus, in the beginning exponential, growth is then linear, until it last reaches a saturation level. The latter results from competition between plants or animals for water, nutrition and - in the case of plants - light. The effect of competition becomes manifest when a population reaches a certain threshold. This logistic growth function has proven to be adequate in many biological and industrial applications.

\subsection{Maize, beans, coffee and pasture stock on the fields}

For coffee, beans and maize the stocks on the fields build up periodically with the cropping seasons and are depleted with the harvests (Figure 5.3). A logistic growth pattern is presumed. Only the harvest product is taken into account, plant material is ignored. Thus, when the grain is harvested, the stock drops to zero until the following cropping season. A further effect integrated for maize, beans and coffee cultivation is the impact of fertilizer application on the saturation level of the growth curve.

\subsection{Forest}

For forest too a logistic growth pattern is assumed, starting from the density of coffee forest. Yet, as forest growth is slow, reaching the level of saturation takes hundreds of years. The dynamics of the forest stock depends on the (im)balance between forest growth and firewood needs. 


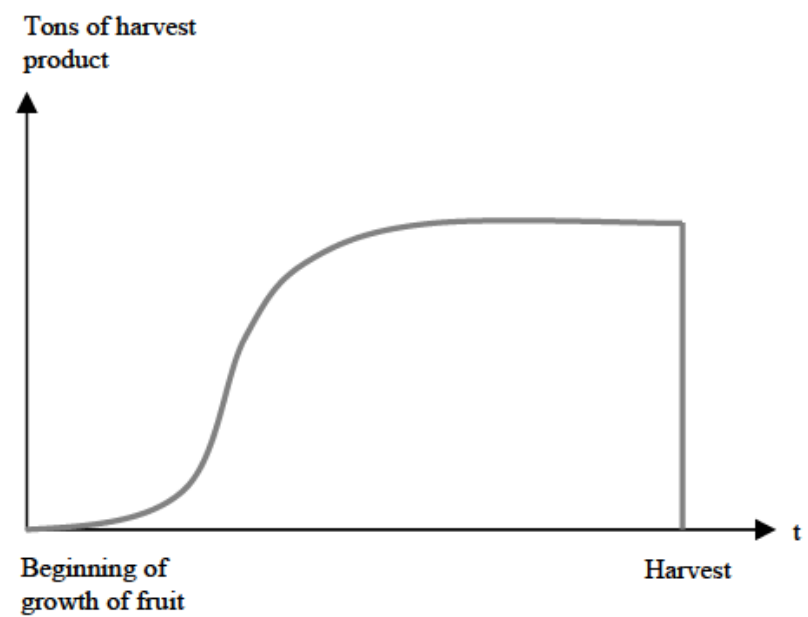

Figure 5.3: Growth curve for the subsystems maize, beans, coffee and pasture: For maize, beans, coffee, and pasture plots a logistic growth curve was assumed. Only the harvest product is represented by the function. Plant material is ignored. After harvest, the stock on the fields drops to zero.

\subsection{Animals}

For individual animals, a logistic growth was assumed. Yet, in a farming system not the individual animal, but the population as a whole is decisive. Populations are biological systems, characterized by stock and reproduction patterns. In agricultural systems they are furthermore strongly influenced by the decisions taken by the agents concerning animal sales, purchase, and consumption. All these factors were included in the model. In addition, the animal populations were divided into age classes. This was necessary because animals reproduce only from a particular age on and have a certain life span. Moreover, farmers consume only animals above a given weight, which - beside other factors - depends on age. In the model, pigs and horses are bought from outside, chicken and cows are bred on the farm. For the latter two species a maximum number of heads has to be pre-determined when running the model. This corresponds to the farmers' knowledge about the ideal flock size, which derives from experience. The surplus is consumed (chicken) or sold (cows). The rapidly growing chicken population always needs a few years to level off, especially with high starting values (Figure 5.4), while the cow population, which is characterized by a slow and low reproduction rate, is quite stable (Figure 5.5). 


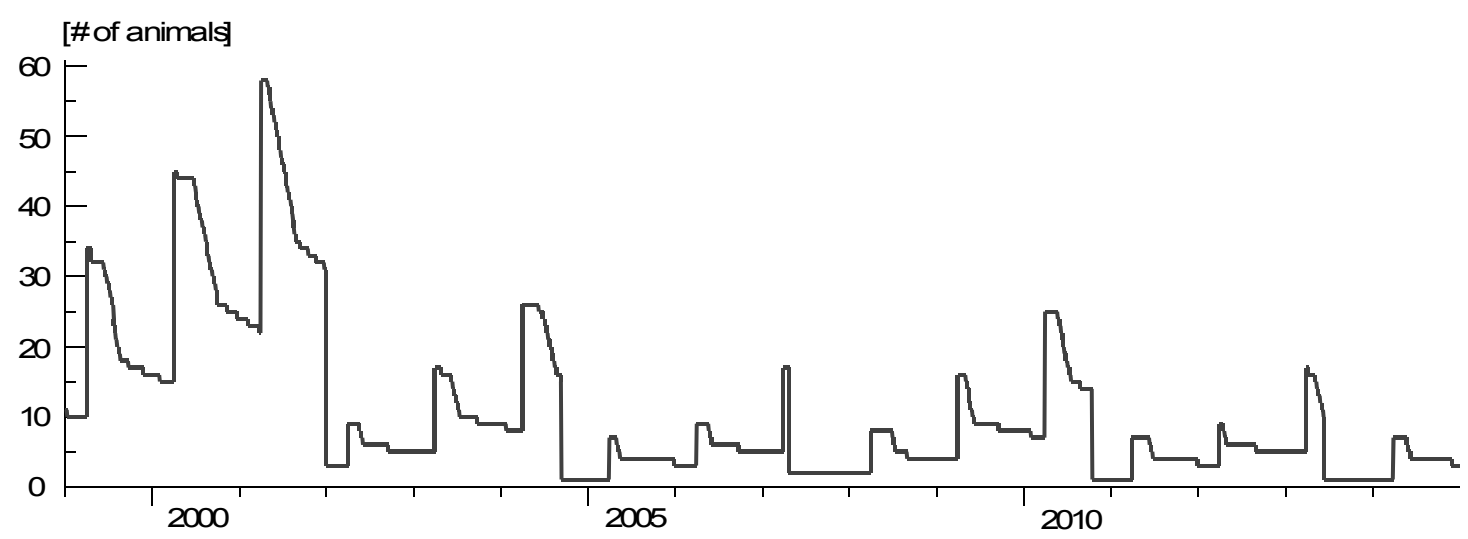

Figure 5.4: Dynamic modeling of the chicken population. As its initial size is relatively big, the population increases considerably and levels off only after about 5-6 years. The abrupt drops in population are caused by the Newcastle disease, which hits the population randomly about every three years (Starting value: 10 hens, chicken per hen and brood: 6, ratio of breeding hens/total: 0.2 , max. hens: 15).
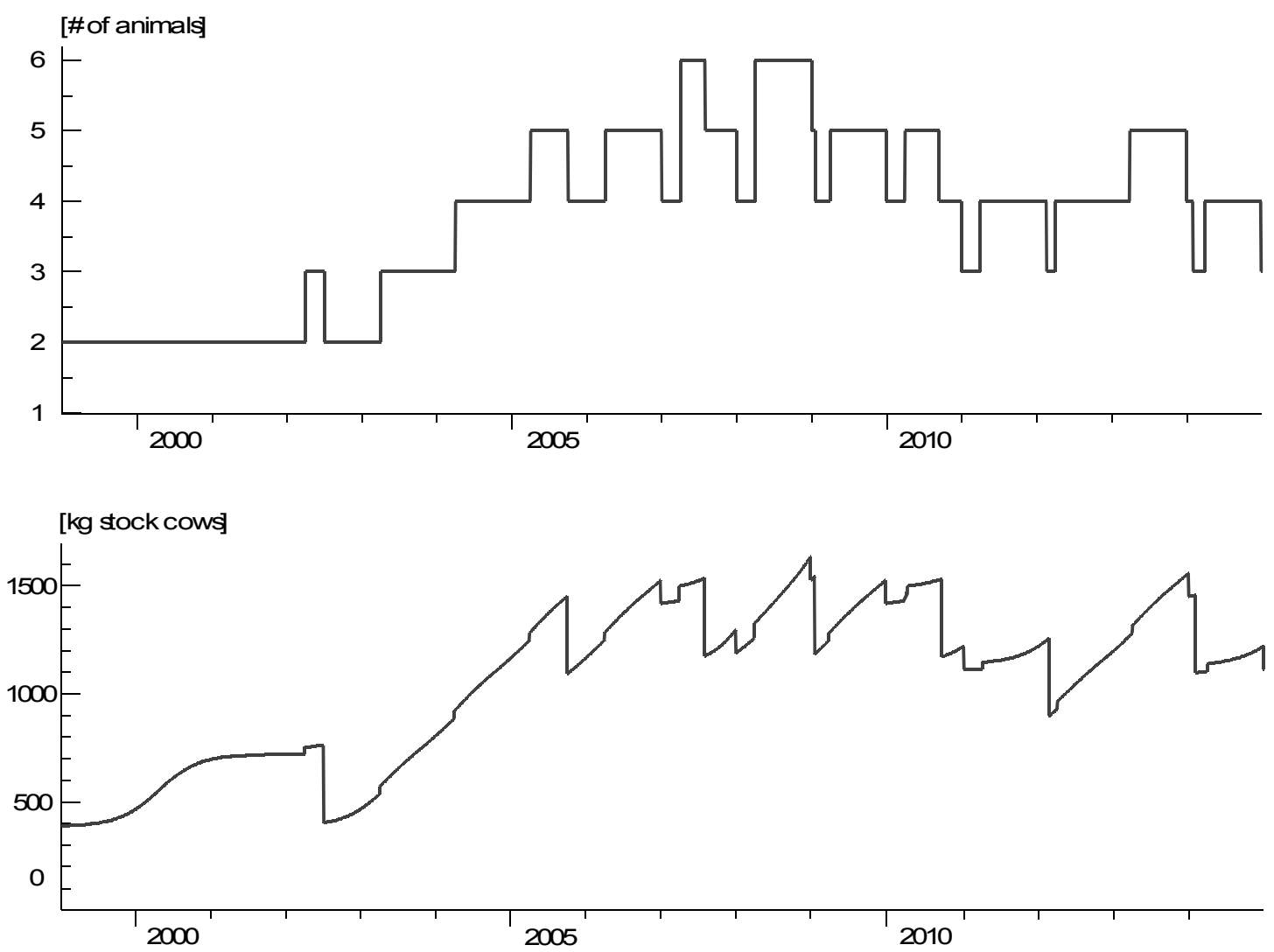

Figure 5.5: Dynamic modeling of the cow population and stock size in kg. The population dynamics are slow compared to the chicken. Thus, it does not need time to level off, but its relatively low starting value, low fertility rate and long reproduction period makes growth slow (Starting value: 2 cows, fertility rate: 0.5 , max. cows: 10 ). 


\subsubsection{Subsystems regulated by agents' decision patterns}

\subsection{Storage}

The stocks in the storage processes are replenished with the harvest produce and then depleted through sales (immediate drop of stock) and on-farm consumption (gradually diminishing stock) (Figure 5.6). The storage processes can thus have two shapes: if the harvest is stored and consumed slowly, it takes shape (a), e.g. in the case of maize, or if part of it is sold immediately and the rest consumed, it takes shape (b), e.g. in the case of beans.

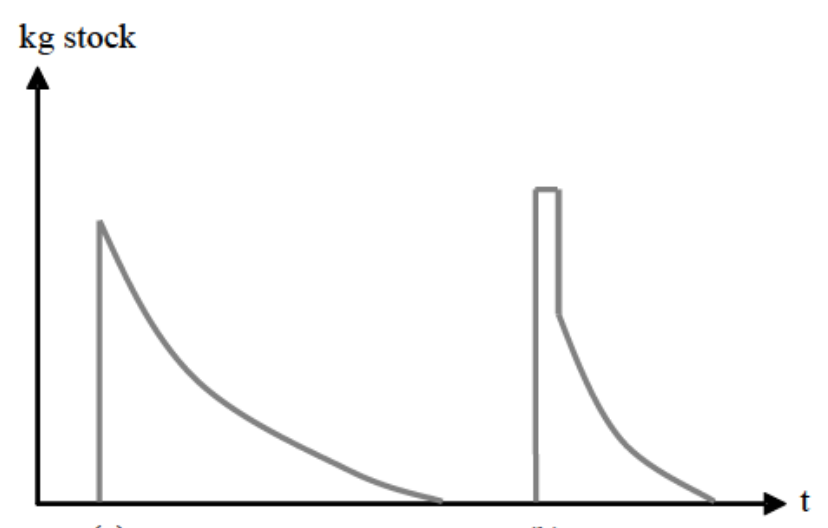

(a)

(b)

Figure 5.6: Storage Processes. The description of the storage management differs for crops, which are grown merely for autoconsumption (a) and for those grown for sale and autoconsumption (b). While in the first case the management function decreases gradually, in the latter case part of the stock is sold immediately, which causes a heavy drop.

\subsection{Consumption patterns}

There are three types of consumption patterns integrated in the model (Figure 5.7). Type (a) exists for instance for firewood, where consumption is constant. For food either type (b) or (c) is foreseen. Both are based on the assumption that consumption patterns adapt to the size of the food stocks. Furthermore, they do not drop below a certain minimum level until the stock is down to zero. In option (b) the adaptation to the stock occurs in steps, while for (c) it is gradual. Nevertheless, calculations have shown that for the system the difference between (b) and (c) is irrelevant. 
This consumption strategy, which at the same time manages stocks, is important for survival: Most people do not have the means to buy their daily food anytime. They depend on their stocks, which have to be well managed until the next harvest.

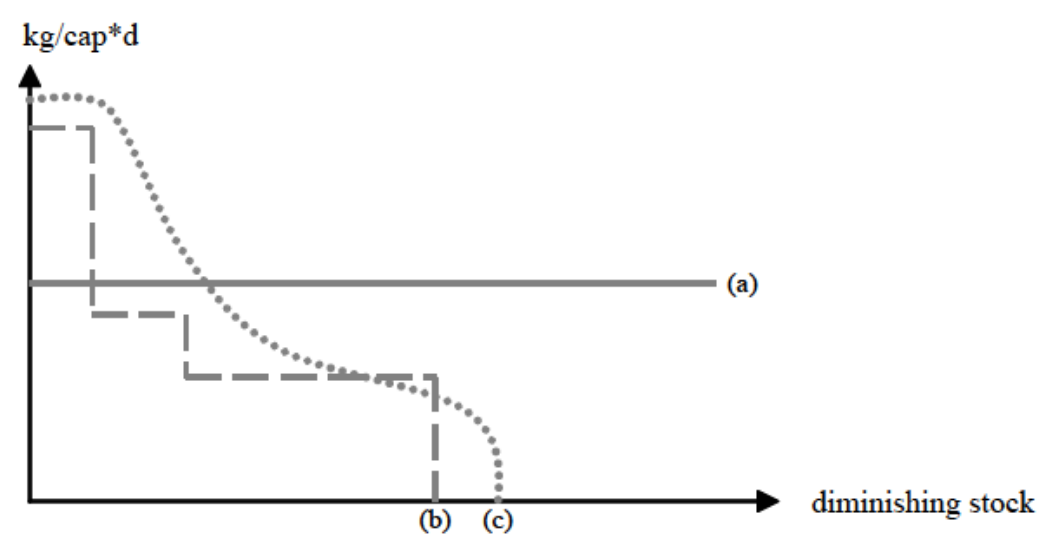

Figure 5.7: Consumption patterns foreseen in the dynamic model. Three consumption patterns are possible: (a) is steady and applies to the case of e.g. firewood, while patterns (b) and (c) are alternative stock-dependent patterns for maize and bean consumption.

\subsubsection{Assumptions}

The following main assumptions have been made for the dynamic model:

(a) The natural conditions are equal for all plots

(b) There are no harvest oscillations due to climatic impacts

(c) From (a) and (b) results that harvest variations are linked only to fertilizer application and plot size. As nitrogen is the limiting factor (Orozco, P.P., personal communication), only fertilizer input of this nutrient was considered.

(d) Horses and pigs are purchased

\subsubsection{Calibration and Recalibration}

In a first step, the model was calibrated. For the growth curves of maize, beans and coffee the calibration was based on data from the farmers interviews. The impact of fertilizer applications on maize was calculated with a rule-of-thumb provided by a researcher working in the region (Orozco, P.P., personal communication). For coffee, 
it was established with information from the farmers, while for beans it was taken from literature (Maingi, J. et al., 2001). The growth curve for pasture was assessed with information from a key person (Schmidt, A., personal communication) and own assumptions. The growth pattern of forest was estimated with data from El Salvador (Rivas, S. 2000), which were completed with personal assumptions. For animals the logistic curves were calibrated with information obtained through interviews with key persons. Furthermore, data on flock and herd size was gathered in the interviews with farmers. Storage and consumption patterns were calibrated with information from the field, which was completed with own assumptions.

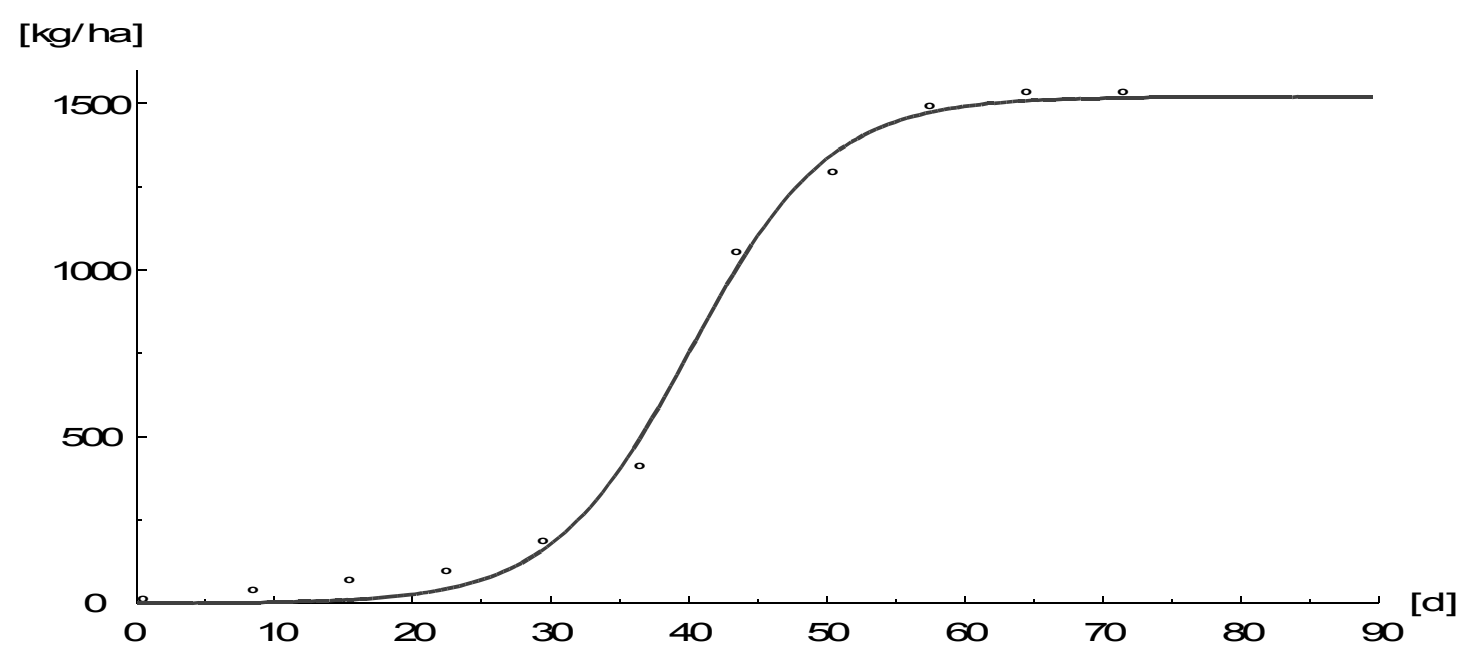

Figure 5.8: Calibration curve for maize. Measured or estimated points were used to calibrate the growth curves, in this case of maize (section 5.2.4).

In a second step, the model was recalibrated based on the system knowledge obtained in the interviews and the quasi-stationary model. Furthermore, some specific factors (e.g. regulation of chicken population, stock management) had been assessed in the interviews. Each subsystem was recalibrated first independently. For maize and beans e.g. this was done by modeling specific farms. In the end the entire system was analyzed. The system has some boundary conditions, which could also be included in the recalibration. A selection of those factors is listed below: 
a) The calorie consumption of humans and animals cannot exceed a certain maximum

b) Many families (landless and small families) suffer from hunger at last in June/July

c) Animal populations do never grow over a certain threshold in non-specialized farming systems

\subsubsection{Data and error estimation}

Most data sources are similar to the quasi-stationary model. Further data has been collected in additional interviews, in some cases with key persons. As there are no similar models for data comparison, error margins - assumed to be quite big - had to be estimated.

\subsection{Computer Program}

The dynamic model for the farming systems in Susulí consists of 130 variables. They are described in 130 nonlinear linked system equations, 98 parameter functions and by means of 353 parameters.

The model was programmed by H.-P. Bader and R. Scheidegger in the computer language RBM (Rocky-Mountain-Basic). It may be run as a subroutine of the program SIMBOX (Baccini and Bader, 1996). All calculations were carried out on a PC with a Pentium(IV) $2 \mathrm{GHz}$ processor and the operating system Windows XP.

\subsection{Scenarios}

As we have seen in the previous chapters, access to land and crop choice are crucial for the vulnerability of a farming system. Thus, with the dynamic model, these two factors were further investigated. The six scenarios chosen for analysis form two groups:

a) Minimum Farms

b) Monocultures 


\subsubsection{Minimum Farms}

In chapter 3 and 4 the problematic situation of the landless population was revealed. As landless farmers are not able to produce their minimum needs on the little land they have access to, they work for landowners to satisfy their most basic needs. Hence, the question raised is how much land a farmer needs to produce the staple he and his family need to survive. What is the surplus required to purchase the minimum needs? Which factors limit the development of these farms?

The scenarios of minimum farms try to assess the minimal size of a farm needed to

a) produce maize and beans for autoconsumption (farm "staples")

b) produce maize and beans for autoconsumption and a surplus of beans for sale to cover the minimum needs (farm canasta mínima)

c) same size as a) but with higher fertilizer input for maize production and fertilizer for bean production (farm "higher input")

For all three options it was assumed that maize was produced for autoconsumption only, thus for humans and chicken on the farm. The family size was equal to six adults $^{24}$. The necessary maize plot size was assessed by modeling the storage stock curve (Figure 5.9), which was allowed to drop nearly to 0 , but not altogether. Thus, the farm was modeled several times with changing maize plot size and a given fertilizer application ${ }^{25}$, until the stock curve looked like in Figure 5.9. The corresponding maize plot size was hence the minimum to supply a family with maize. For scenario a) bean plots' size were determined alike, while for b) the amount of surplus beans necessary for the purchase of the minimum needs was computed (Table 5.1). Option c) has the same total farm size as a), but higher fertilizer input - it is actually at the limit of real application by the farmers of the study region. Thus, the quantity of maize necessary to satisfy the family's needs can be produced on a smaller plot and the rest of the land is used to produce a surplus of beans for sale.

\footnotetext{
${ }^{24}$ Children until they are 18 years old count as 0.75 adults.

${ }^{25}$ Chosen fertilizer input is higher than in chapter 3 and 4, as in other communities of San Dionisio more fertilizer is applied than in Susulí.
} 


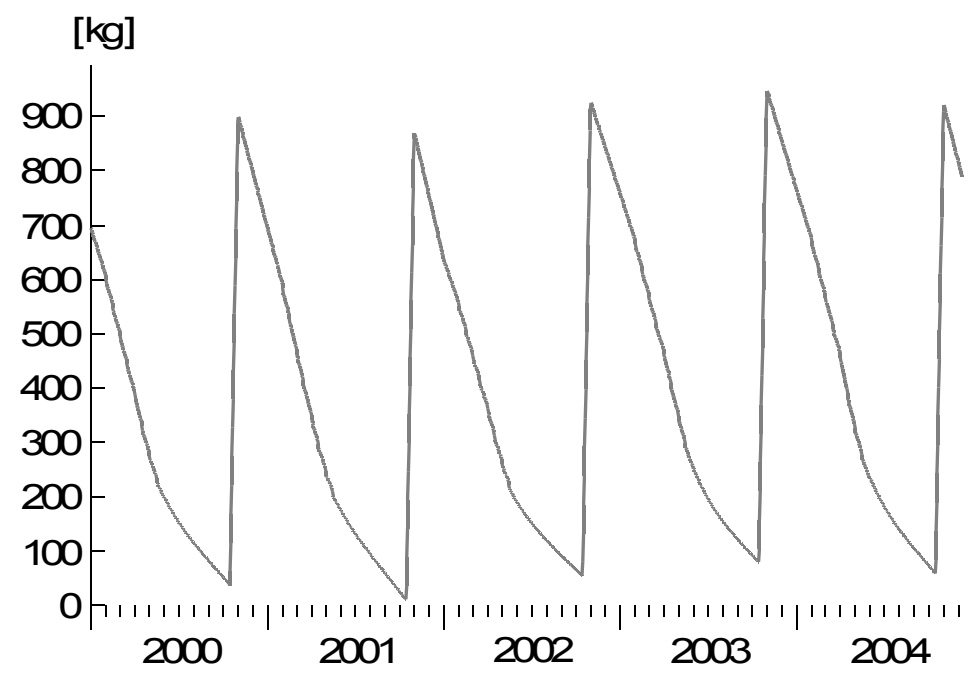

Figure 5.9: Maize stock in minimum farm-modeling. Maize stock was modeled with various plot sizes. It was neither allowed to drop completely to zero, nor to build up big reserves, as it is mainly grown for autoconsumption. For the ideal curve the corresponding plot size was determined.

\begin{tabular}{|c|c|c|c|}
\hline Parameter & $\begin{array}{l}\text { Minimum farm } \\
\text { "staples" }\end{array}$ & $\begin{array}{l}\text { Minimum farm } \\
\text { “Canasta Mínima” }\end{array}$ & $\begin{array}{l}\text { Minimum farm } \\
\text { "higher input" }\end{array}$ \\
\hline Area Maize [ha] & $?$ & Same as "staples" & $?$ \\
\hline Area Beans Primera [ha] & $?$ & $?$ & $?$ \\
\hline Area Beans Postrera [ha] & $?$ & $?$ & $?$ \\
\hline $\begin{array}{l}\text { Min. Total Area per } \\
\text { Family per Year [ha] }\end{array}$ & $?$ & $?$ & Same as "staples" \\
\hline $\begin{array}{l}\text { Fertilizer Nitrogen } \\
\text { applied to Maize }[\mathrm{kg} / \mathrm{ha}]\end{array}$ & 130 & 130 & 260 \\
\hline $\begin{array}{l}\text { Fertilizer Nitrogen } \\
\text { applied to Beans }[\mathrm{kg} / \mathrm{ha}]\end{array}$ & 0 & 0 & 130 \\
\hline Maximum Chicken [\#] & 6 & 6 & 6 \\
\hline Needs Covered & Staples & Minimum Needs & Staples $+?$ \\
\hline Family Size & 6 & 6 & 6 \\
\hline
\end{tabular}

Table 5.1: Setting for the minimum farms. There are three options. "Staples" assesses the land needed for the auto-supply of staples for a family of six (definition: stock should never be 0), canasta minima determines the land needed for the coverage of the minimum needs and the "high input farm" is based on the same land resources as "staples" and estimates the impact of optimal fertilizer use. 
In all three cases, the fertilizer costs for maize were accounted for. Thus, part of the beans is being sold in order to purchase the necessary fertilizer.

\subsubsection{Monocultures}

Time and again, international or national agencies propose that farmers concentrate on one $\operatorname{crop}^{26}$. The following scenarios were created in order to grasp the impact such a drastic move could have on the farming system and the food security. Monoculture farming systems were set up for the main crops or produce of the study region and compared (Table 5.2). Four options were analyzed:

a) Maize and animal production depending on maize for fodder (chicken and pigs)

b) Beans

c) Coffee

d) Animal husbandry

Again, the assumed family size was 6 . The following adaptations to parameter have been made: While usually beans are consumed at 100-200 g/cap*d, for the calculation of bean calorie production the consumption rises to $400 \mathrm{~g} / \mathrm{cap} * \mathrm{~d}$ of beans. This is such in order to compare the potentials objectively, as maize is eaten at up to $400 \mathrm{~g} / \mathrm{cap}^{*} \mathrm{~d}$. For pasture plots, figures are calculated for 7 ha and standardized to 1 ha. This allows the assessment of realistic averages: Plots cannot be overstocked. Farmers speak of maximum one local cattle unit per 0.7 ha. Thus, on a 1 ha plot there would be one cow, while on 2 ha there would be already three. Furthermore, cow fertility rate is low. Thus, one cow calves once every two years and therefore at the same interval no milk is produced. Nevertheless, this does not represent the average milk production per ha if more animals and more land are owned. Thus, figures were standardized. For the calculations of calorie production the cows, which are usually sold, have not been included in the model. Yet, they have been included in the protein calculations and the added value. For coffee forest, the firewood was not given a price, as at the moment most people gather it for free.

\footnotetext{
${ }^{26}$ It has to be emphasized though, that currently in Central America the contrary is suggested.
} 


\begin{tabular}{lcccc}
\hline Parameter & Maize & Beans & Coffee & Pasture \\
\hline Area Maize [ha] & 1 & 0 & 0 & 0 \\
Area Beans Primera [ha] & 0 & 1 & 0 & 0 \\
Area Beans Postrera [ha] & 0 & 1 & 0 & 0 \\
Area Coffee [ha] & 0 & 0 & 1 & 0 \\
Area Pasture [ha] & 0 & 0 & 0 & 1 \\
Total Area [ha] & 1 & 1 & 1 & 1 \\
$\begin{array}{l}\text { Fertilizer Nitrogen Input } \\
\text { [kg/ha] }\end{array}$ & 130 & 0 & 0 & 0 \\
Gramoxone [lt/ha] & 4.1 & 2.8 & 0 & 0 \\
Maximum Chicken & 11 & 0 & 0 & 0 \\
Pigs & 1 & 0 & 0 & 0 \\
Maximum Cows [cap/ha] & 0 & 0 & 0 & 1 \\
Family Size & 6 & 6 & 6 & 6 \\
$\begin{array}{l}\text { Max. consumption } \\
\text { [kg/cap*d] }\end{array}$ & 0.4 & 0.4 & 0 & 0 \\
\hline
\end{tabular}

Table 5.2: Setup of the scenario group "monocultures": For the second group of scenarios, monoculture systems of 1 ha were set up for the main agricultural produce of the region. As chicken and pigs are fed with maize, only this monoculture includes these animals, while cows are held only in the pasture system.

\subsection{Evaluation Criteria}

The scenarios were evaluated with three evaluation criteria.

a) Production of calories and proteins

b) Production of added value

c) Need of workforce 
In an agricultural system, where a big share of the produce is used for autoconsumption, the calorie yield of a crop plays a crucial role. It was assumed that Nicaraguan farmers, who do a lot of physical work, need between 2200 and 2700 $\mathrm{kcal} / \mathrm{cap} * \mathrm{~d}$. Women and children require somewhat less. Nevertheless, not only calorie content of a food determines its nutritional value. One further important factor is its protein content. Therefore, calorie and protein production of each monoculture scenario were investigated. While these two indicators are directed mostly at products for autoconsumption, for cash crops like coffee the revenue is most important Thus, the production of added value was chosen as a further indicator. Last but not least, a family-run farm relies mostly on family workforce, as employed labor implies high costs at a time when means are scarce. Thus, the need for day-laborers had to be estimated for each farming system in order for it to be in the range of the farms' possibilities. It is assumed that one family has a maximum of 4 workers.

\subsection{Results}

\subsubsection{Minimum Farms}

The land needed for providing a family of 6 with the basic staple needs (food and fodder for chicken) is 1.25 ha. Of these 0.75 ha are cultivated in primera, whereof $2 / 3$ are used for maize cropping, and 0.5 ha in postrera (Figure 5.10, Table 5.3). The amount of beans sold by these farmers is virtually zero (Figure 5.11 and 5.12). If the minimum needs are to be covered (see section 2.5.2), then double the land is required, namely 3.25 ha -1.75 ha in primera and 1.5 ha in postrera. Of the former, 0.5 ha is maize crop. This farmer sells about $1300 \mathrm{~kg}$ of beans, for which he must obtain at least C\$ $250 / \mathrm{qq}^{27}$ to come up for the minimum needs. The "higher input" farmer frees 2/5 of the land hitherto used for maize by doubling the fertilizer input. Thus, he may grow additional beans for sale. As furthermore fertilizer is applied to bean plots, he produces an additional surplus of roughly $800 \mathrm{~kg}$. That way, roughly half of the canasta mínima may be purchased. Besides food, the families also require firewood.

\footnotetext{
${ }^{27}$ US\$ 39 per $100 \mathrm{~kg}$.
} 
If we assume a production of $9 \mathrm{t} / \mathrm{ha}$ of wood per hectare of forest, each family additionally needs a forest plot of 0.75 ha. Hence, for the option "staples" a total of 1.5ha is needed per family and year, which means that 807 families could provide themselves with staples and energy on the area of Susulí. In order to obtain the minimum needs, only 484 families - roughly the current population - could live in the area. Yet, a precondition for this is stable, average yields, which currently are not harvested in the study region.

\begin{tabular}{llll}
\hline Parameter & $\begin{array}{l}\text { Minimum farm } \\
\text { “staples” }\end{array}$ & $\begin{array}{l}\text { Minimum farm } \\
\text { “Canasta Minima” }\end{array}$ & $\begin{array}{l}\text { Minimum farm } \\
\text { “higher input” }\end{array}$ \\
\hline Area Maize [ha] & 0.5 & 0.5 & 0.5 \\
Area Beans Primera [ha] & 0.25 & 1.25 & 0.25 \\
Area Beans Postrera [ha] & 0.5 & 1.5 & 0.5 \\
$\begin{array}{l}\text { Min. Total Area per } \\
\text { Family per Year [ha] }\end{array}$ & 0.75 & 1.75 & 0.75 \\
$\begin{array}{l}\text { Fertilizer nitrogen maize } \\
\text { [kg/ha] }\end{array}$ & 130 & 130 & 260 \\
$\begin{array}{l}\text { Fertilizer nitrogen beans } \\
\text { [kg/ha] }\end{array}$ & 0 & 0 & 130 \\
Maximum chicken [\#] & 6 & 6 & 6 \\
$\begin{array}{l}\text { Needs Covered } \\
\text { Family Size }\end{array}$ & Staples & Minimum Needs & $\begin{array}{l}\text { Staples + half of the } \\
\text { Minimum Needs }\end{array}$ \\
\hline
\end{tabular}

Table 5.3: Results for the minimum farm scenarios. For the coverage of the staple needs of a family of 6, less than 1ha of land is sufficient. Yet, if the minimum needs are to be covered the need of land rises up to 1.75 ha. With higher inputs, on the same plots as scenario "staples" half of the minimum needs can be gained. 


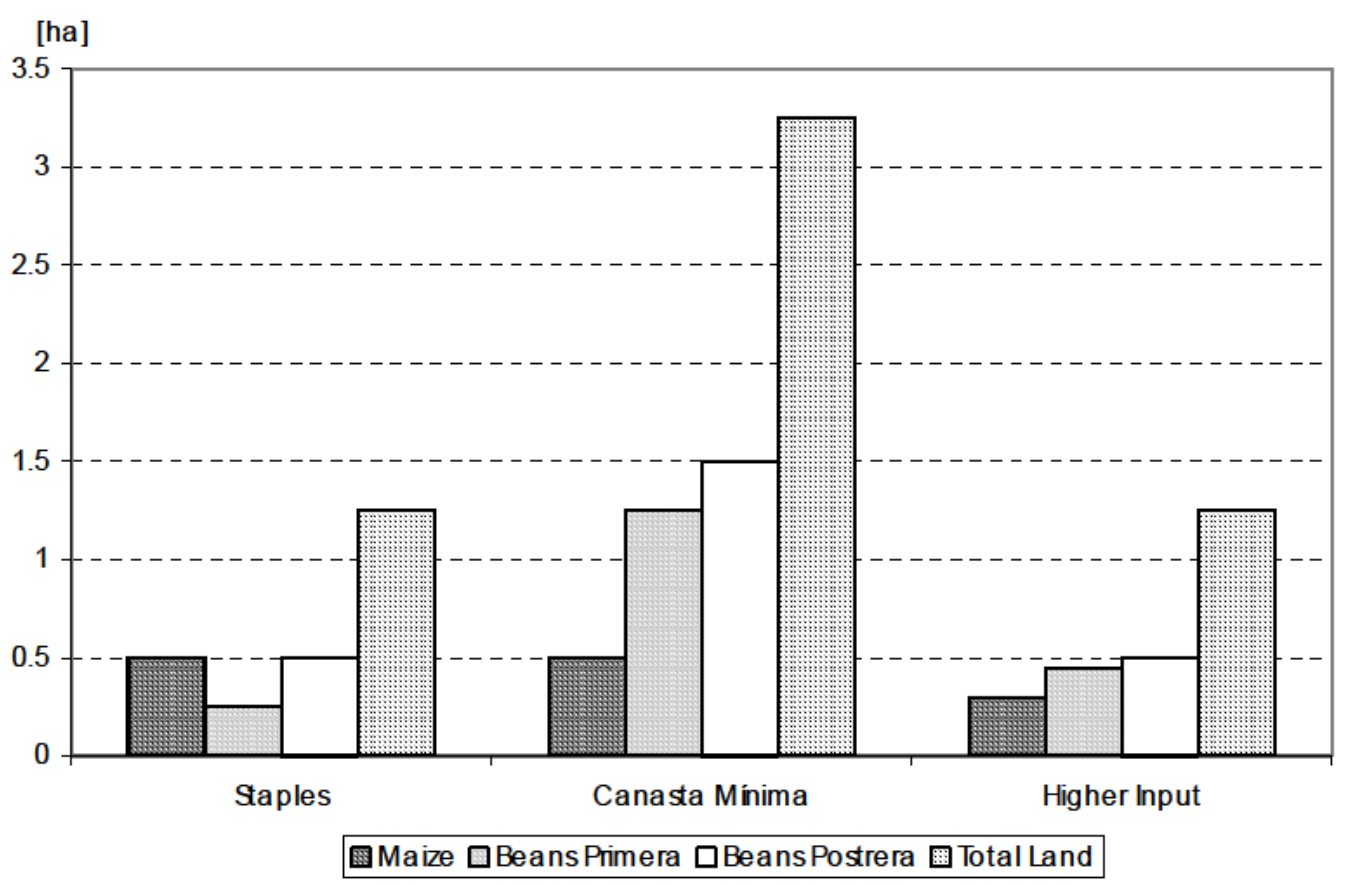

Figure 5.10: Land need for the three scenarios "staples", "canasta minima" and "higher input" farm (top-down). The land necessary to cover the minimum needs is more than double of that one to cover the staple demand. With higher chemical input, maize needed for auto-supply can be produced on $2 / 3$ of the land, which frees land for growing beans.

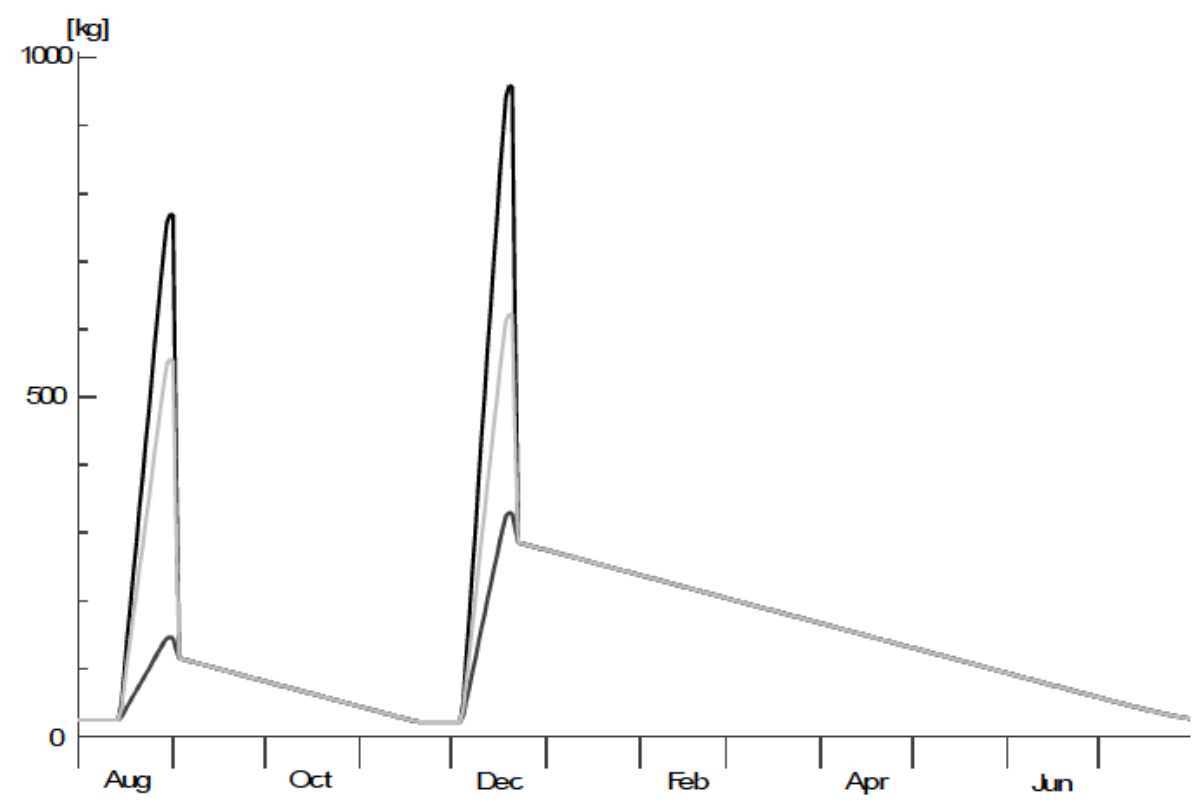

Figure 5.11: Bean stock for the three minimum farm scenarios. The day of the harvest the stock is replenished (peak). The surplus is then sold immediately (drop) and the rest is consumed (steadily decreasing stock). Grain set aside per family member and consumption pattern were set to be the same for all three scenarios. "Staples" (dark grey), "canasta minima" (black) and "Higher Input" (light grey). 

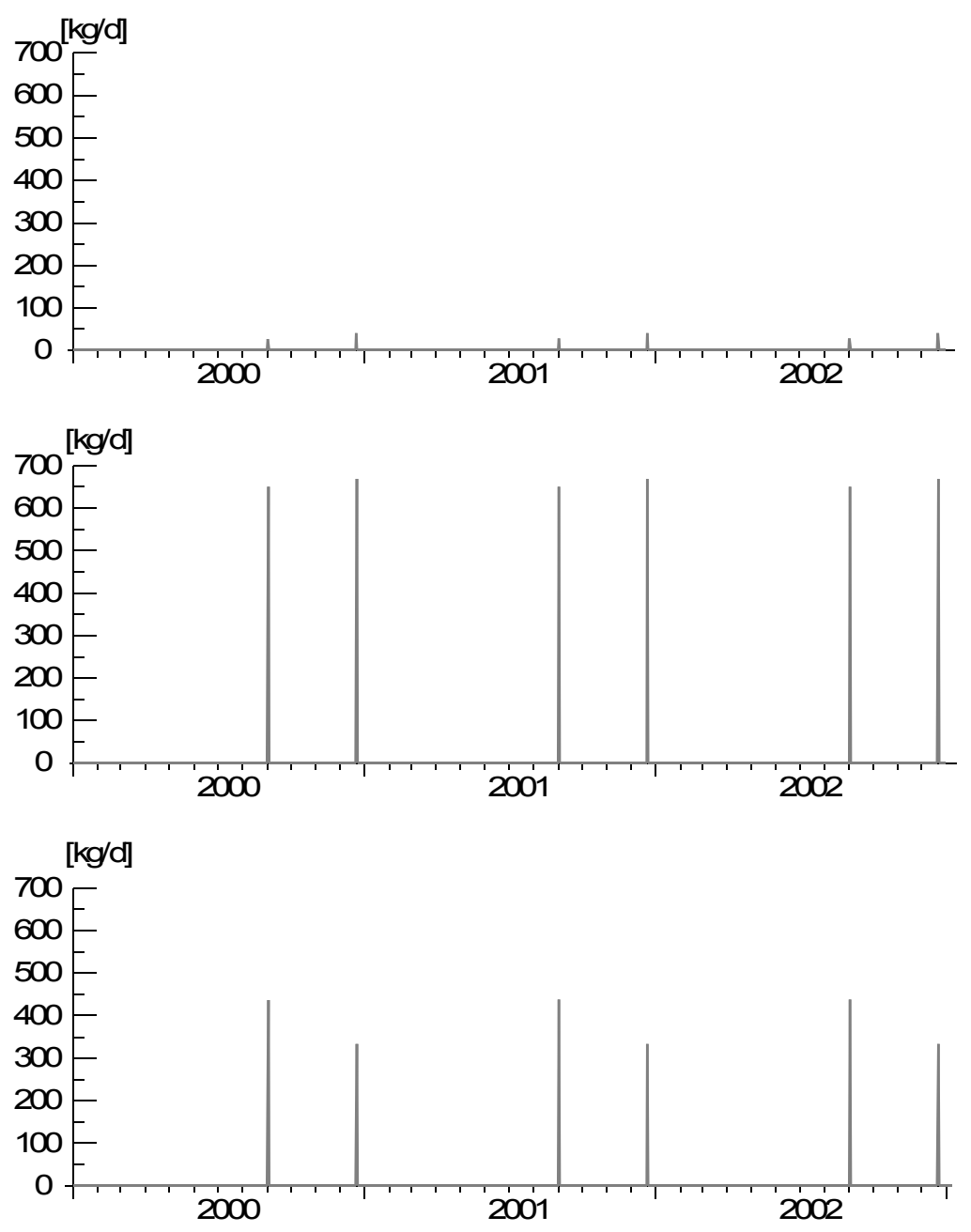

Figure 5.12: Beans sold for the scenarios "staples", "canasta mínima" and "higher input" farm (top-down). The minimum farm "staples" does hardly sell any beans, "canasta mínima" produces a surplus of about $1300 \mathrm{~kg} / \mathrm{a}$, while "higher input" with the same access to land as "staples" sells about $800 \mathrm{~kg} / \mathrm{a}$.

The bean storage stock (Figure 5.11) increases sharply during times of harvest, after which the surplus beans are sold immediately. Storage management and bean consumption were modeled to be equal for all three scenarios. Yet, the resulting consumption curves were found to be different (Figure 5.13). This is such because of the pre-harvest of beans, when young tender beans are gathered for autoconsumption. While for scenario "staples" the consumption curve drops under $100 \mathrm{~g} / \mathrm{cap} * \mathrm{~d}$ before harvest, for scenario canasta mínima it decreases slightly and recovers immediately by the quantity of young beans harvested (bean plots are biggest for this scenario). The "higher input" farmer lies in-between the other two. The bean consumption of his 
family drops before harvest, increases somewhat with the pre-harvest and raises to full consumption $(200 \mathrm{~g} / \mathrm{cap} * \mathrm{~d})$ again when beans are harvested.
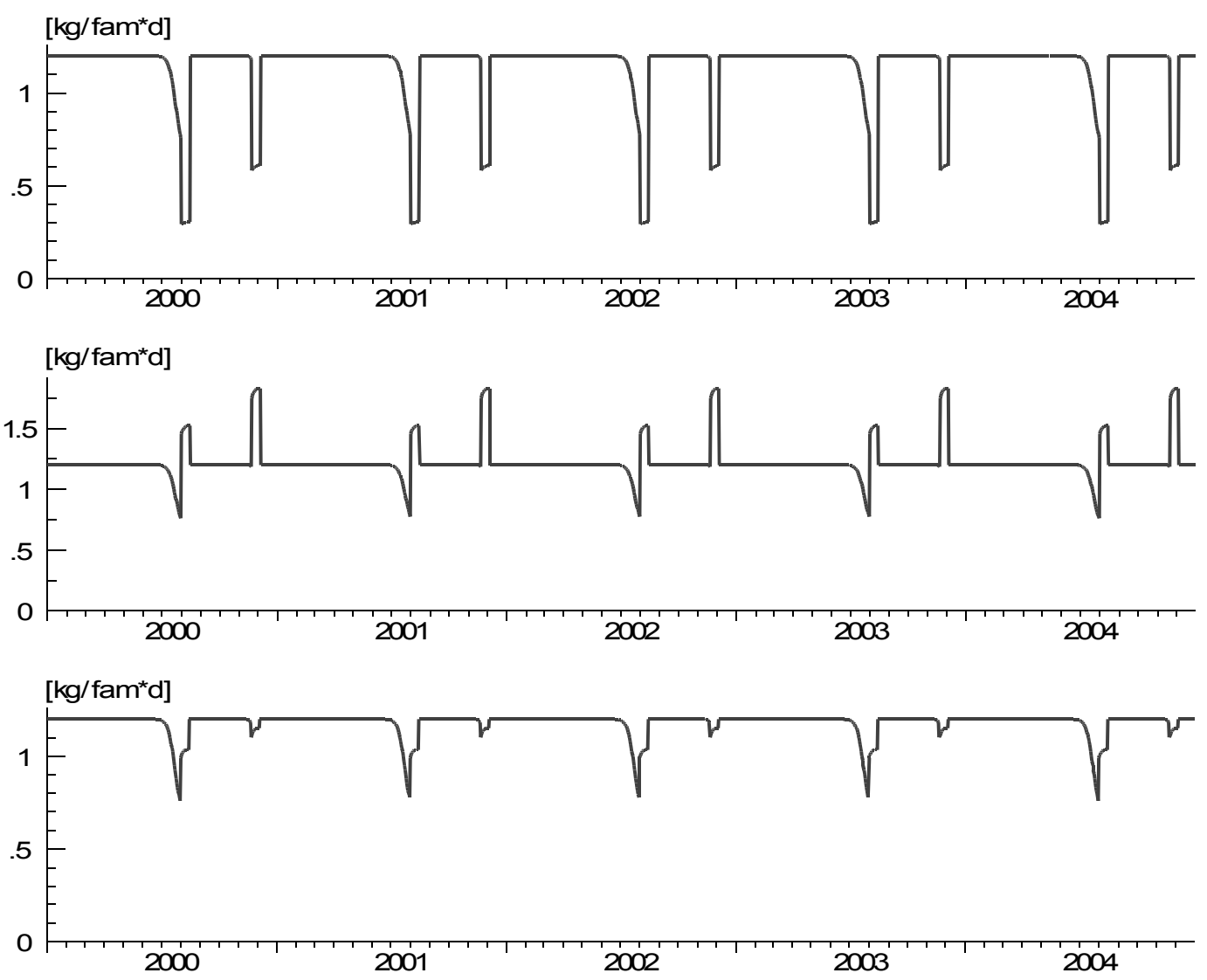

Figure 5.13: Bean consumption patterns for the three scenarios "staples", "canasta mínima" and "higher input" farm (top-down). Although the stock change (figure 5.10) is equal, the consumption patterns of the families of the three scenarios vary. While for scenario "staple" consumption drops to less than $100 \mathrm{~g} / \mathrm{cap} * \mathrm{~d}$ before harvest, the bean consumption of the scenario "canasta minima" decreases only slightly and recovers with the pre-harvest (peaks) of young beans. The scenario "higher input" drops also slightly, recovers somewhat with the pre-harvest and gets back up to $200 \mathrm{~g} / \mathrm{cap} * \mathrm{~d}$ with the harvest.

For the calorie supply of the farmers' families the following results have been obtained (Figure 5.14): Maize consumption, according to the set up of the farms, is the same for all three minimum farms with small alterations due to different oscillations in the chicken stock. The calories obtained from maize lie between 500 and $1500 \mathrm{kcal} / \mathrm{cap} * \mathrm{~d}$. This range is so wide because with diminishing reserves daily consumption drops considerably. Nevertheless, calories supplied by maize make up for the most important share of the total. The energy derived from beans amount to $500-700 \mathrm{kcal} /$ cap*$^{*} \mathrm{~d}$ for the scenario "staples" and "higher input". For the minimum 
needs it amounts to $600-1100 \mathrm{kcal} / \mathrm{cap}^{*} \mathrm{~d}$. As eggs account only for a small share of the calorie input (max. $60 \mathrm{kcal} / \mathrm{cap}^{*} \mathrm{~d}$ ), oscillations due to different hen population do not have a big impact on total calorie consumption (Figure 5.14). The latter ranges from 800-2250 kcal/cap*d for the "staple" farm. Thus, mostly it is below the minimum calorie need of around $2200 \mathrm{kcal} / \mathrm{cap}^{*} \mathrm{~d}$. For the "higher input" farm it is considerably higher lying between 1600 and $2600 \mathrm{kcal} / \mathrm{cap}^{*} \mathrm{~d}$. Last but not least, for the option canasta minima the calorie intake ranks from 2000-3000 kcal/cap*d. During pre-harvest it lies higher for a short time. The differences in calorie supply mainly result from the purchase of rice, sugar and oil with the revenue of the beans' sale.
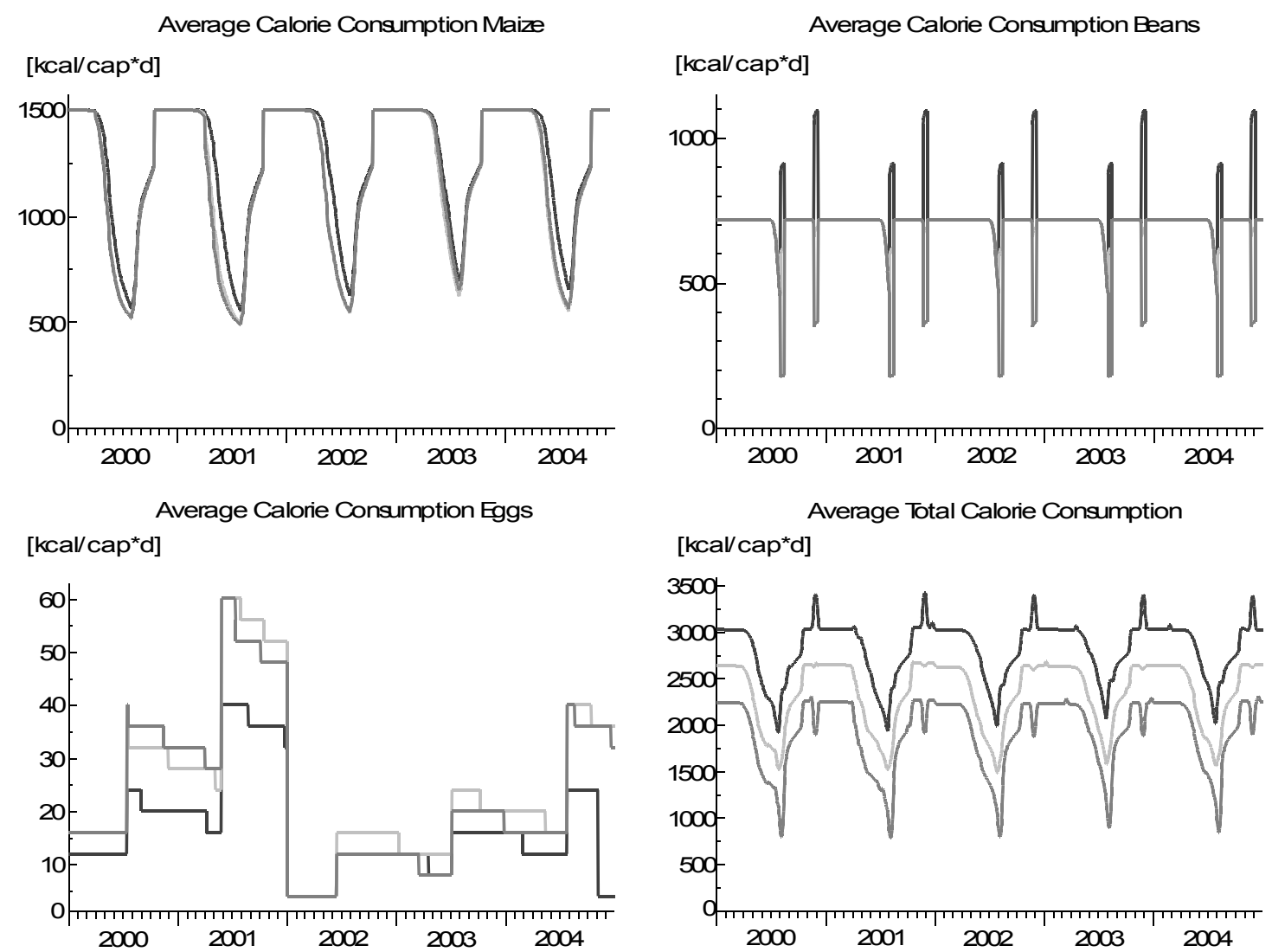

Figure 5.14: Calorie production and consumption for the three minimum farms "staple", "canasta mínima" and "higher input". Maize is the most important on-farm calorie supply, followed by beans, while eggs can be neglected. Biggest long-term differences in calorie intake exist for total calorie consumption, depending mainly on whether sugar, rice and oil can be afforded. The peaks in the graphs "average consumption beans" and "average total calorie consumption" indicate the pre-harverst of beans ("staples": dark grey, "canasta mínima": black, "higher input" farm: light grey) 
The workforce needed for the three scenarios is shown in Figure 5.15 and 5.16. The former depicts the maximum peaks, while the latter shows the normal workload. Not surprisingly the biggest sized farm canasta mínima also shows the highest workforce requirements. Thus, during sowing period for beans the demand rises to 145 (primera) and 175 (postrera) h/d, corresponding to 18 and 22 workers, if all the plots are sown on the same day. For the scenario "staples" the maximum workforce requirements sum up to $59 \mathrm{~h} / \mathrm{d}$ in postrera, which represents 7.3 workers, the same as for scenario "higher input" farm. Nevertheless, the latter has additionally a similar peak in primera. If the normal workload apart from the peaks is analyzed (Figure 5.16), it amounts to an average of about 6-13 h/d (staples), 14-18 h/d (canasta mínima) and 8$12 \mathrm{~h} / \mathrm{d}$ ("higher input"), which corresponds to 1-1.5, 2 and 1-1.5 workers per farm.

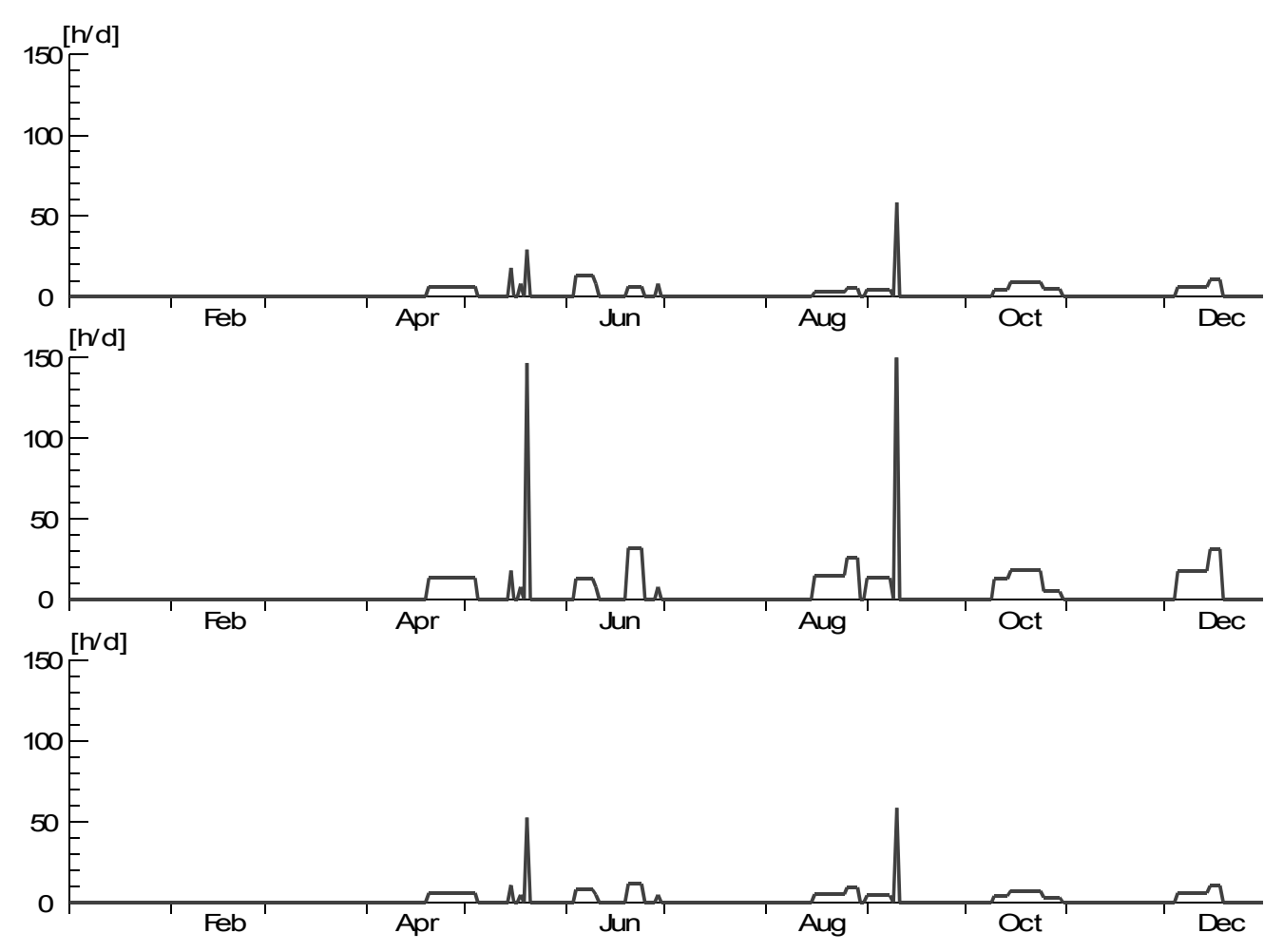

Figure 5.15: Workforce needed for scenarios "staples", "canasta mínima" and "higher input" Peaks. Total labor demand is shown for the three farms. Canasta mínima has the highest labor demand, which during work peaks rises up to $175 \mathrm{~h} / \mathrm{d}$, which corresponds to 22 workers. 

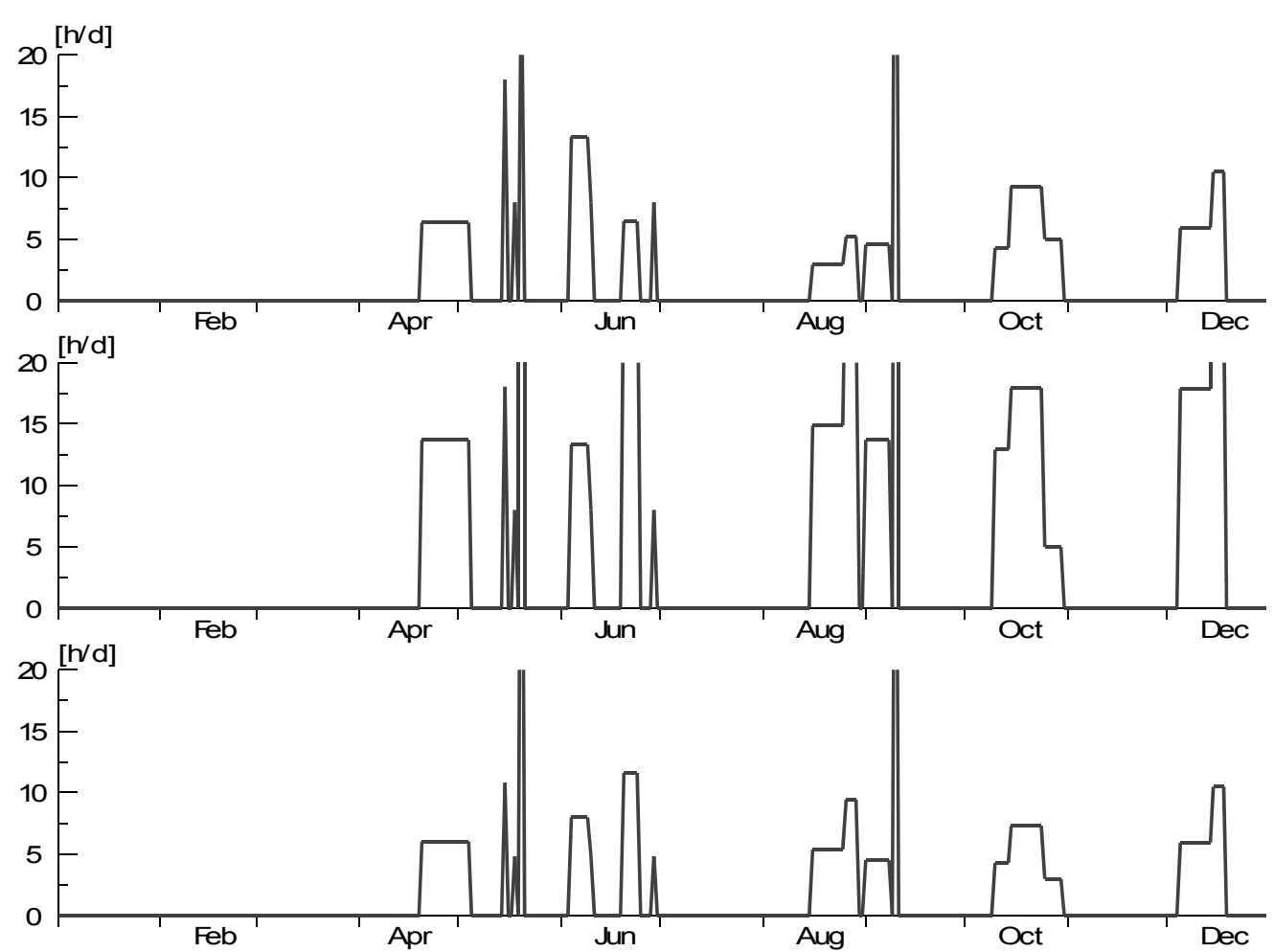

Figure 5.16: Workforce needed for scenarios "staple", "canasta mínima" and "higher input" Resolution. Apart from work peaks, labor demand lies in a range of 6-13 h/d for the farm "staples, 14$18 \mathrm{~h} / \mathrm{d}$ for the farm "canasta minima" and 8-12 h/d for the farm "higher input".

\subsubsection{Monocultures}

When cultivating monocultures of 1 ha, most calories $(1500-3000 \mathrm{kcal} / \mathrm{cap} * \mathrm{~d})$ are produced with maize, even though in the model only one cropping season for maize is foreseen. Many calories are consumed when maize is pre-harvested (smaller peak). The supply with egg and meat calories is included in this figure, as chicken and pigs are fed with maize (Figure 5.17). For the monoculture maize there are calorie consumption peaks which rise up to $4000 \mathrm{kcal} / \mathrm{cap} * \mathrm{~d}$. These correspond to the sacrifice of pigs. Usually, these are slaughtered when an important event is celebrated and shared with the neighbors. Thus, calorie consumption is actually not quite that high. Second to maize in calorie production are beans, which produce about 750-1400 $\mathrm{kcal} / \mathrm{cap}^{*} \mathrm{~d}$ per hectare. While coffee plots do not produce calories, pasture plots generate merely about $150 \mathrm{kcal} / \mathrm{cap}^{*} \mathrm{~d}$ in form of milk. Furthermore, the distribution of these calories is highly irregular, as cows give milk at most during about 7 months 
a year. Furthermore, in the study region the product can only be stored for a few days at most, as virtually nobody owns refrigerators. Thus, there are periods without any calorie input from pasture plots, if no animals are sacrificed. Although these provide roughly 30'000 kcal per animal, their meat cannot be stored because of the reasons mentioned above and is thus useless for long-term calorie supply.

As regards the protein production of the four systems, beans produce most proteins per ha (Figure 5.18), namely roughly $240 \mathrm{~kg} / \mathrm{ha}$ a, which corresponds to about the yearly protein need of two families of $\operatorname{six}^{28}$. With $120 \mathrm{~kg} / \mathrm{ha} * \mathrm{a}$ maize cultivation produces half the proteins of beans. Only $9 \%$ of these are animal derived. Pasture plots do provide about $63 \mathrm{~kg} / \mathrm{a}$ of proteins in form of milk and meat. Last but not least, coffee plots produce neither calories, nor proteins, apart from some fruit like oranges.

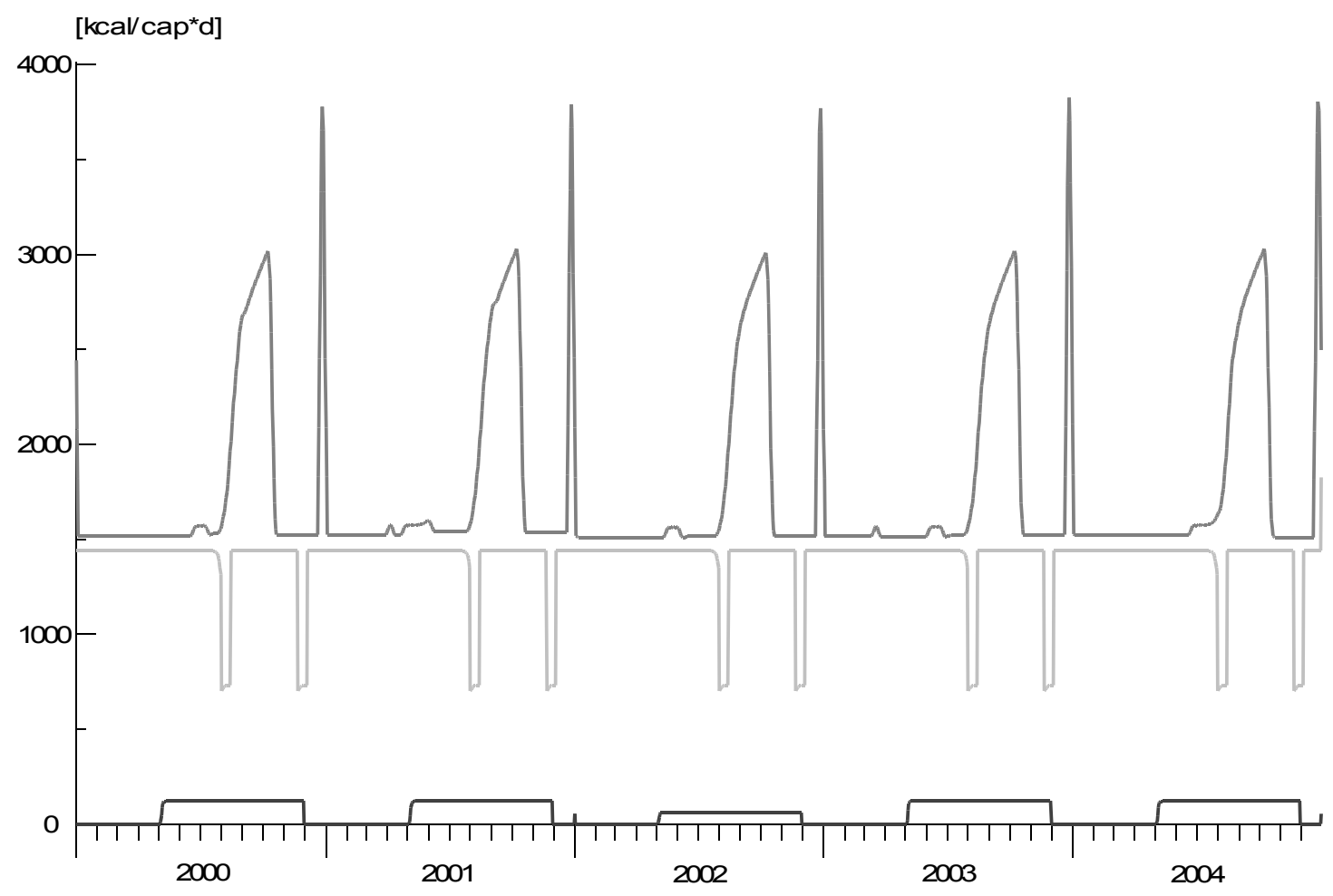

Figure 5.17: Average calorie production of 1ha monocultures maize (dark grey), beans (light grey) and pasture (black) for a family of 6 . Maize yields most calories per ha, namely about 1500 $3000 \mathrm{kcal} / \mathrm{cap} * \mathrm{~d}$. Peaks occur due to the sacrifice of a pig and amount up to $4000 \mathrm{kcal}$. Bean production produces $750-1400 \mathrm{kcal} / \mathrm{cap}^{*} \mathrm{~d}$, while pasture plots barely produce calories (ca. $150 \mathrm{kcal} / \mathrm{cap} * \mathrm{~d}$ ) in form of milk. If cows were sacrificed and not sold, there would be additionally calorie peaks of several thousand. Coffee plots do not supply calories.

\footnotetext{
${ }^{28}$ If we assume a protein need of $50 \mathrm{~g} /$ pers*d, regardless of the amino acid composition.
} 


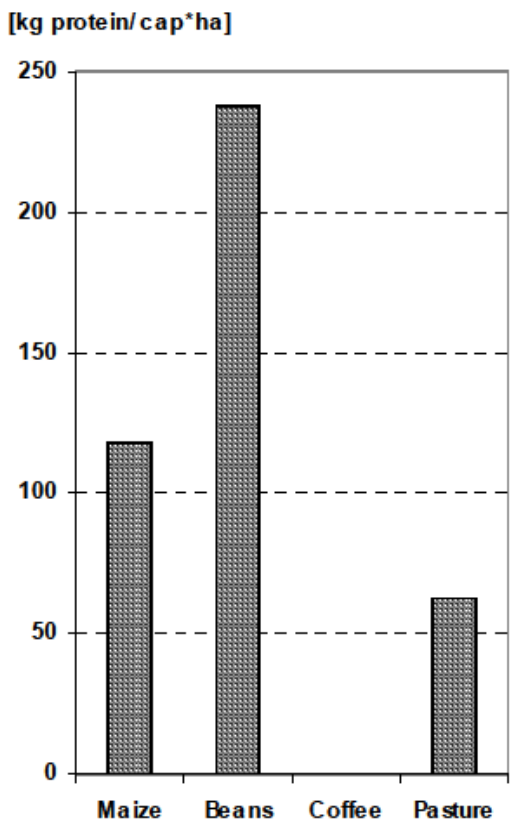

Figure 5.18: Protein production of monoculture scenarios. Bean cultivation produces most proteins per ha (about $240 \mathrm{~kg} / \mathrm{cap} * \mathrm{a}$ ). Maize ranks second, including the production of meat and eggs. Coffee growing does not provide any protein, cattle ranching about $63 \mathrm{~kg} / \mathrm{cap} *$ a with milk and meat.

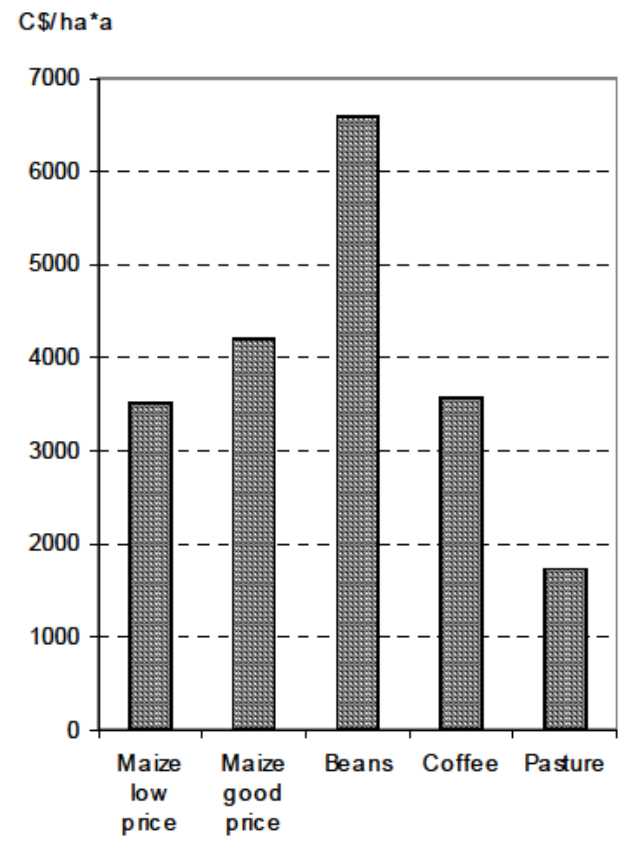

Figure 5.19: Added value produced with monoculture scenarios. The highest revenue per hectare can be obtained with bean cropping. If maize can be stored and a good price be obtained, it ranks second before coffee. In the case maize is badly paid, it produces less revenue than coffee. Only little money per hectare is made with pasture. 
Of the four scenarios, beans produce the biggest gains with about C\$ 6'500 (US\$ 464) per year at the current price (Figure 5.19). If a good price is obtained for maize, it follows on rank two. Yet, for that maize has to be stored for several months before it can be sold. It has been mentioned before, that this is mainly done by medium and big farmers. Small and landless farmers mostly sell maize - if at all - at a much lower price. Thus with a monoculture maize they earn only about $84 \%$ of the revenue of those who are able to wait for rising prices. This is just about the C\$ 3'600 (US\$ 255) which at present can be earned with 1 ha of low input coffee. Pasture plots produce less than C\$2'000/ha*a (US\$ 143).

Workforce peaks (Figure 5.20) are highest for beans. They amount to $120 \mathrm{~h} / \mathrm{d}$, thus to 15 persons, if one plot has to be sown in one day. If we assume that the 1ha plot is divided into three smaller plots, which are sown on one day each, the farmer needs 5 workers a day, which means at least one outside workforce.
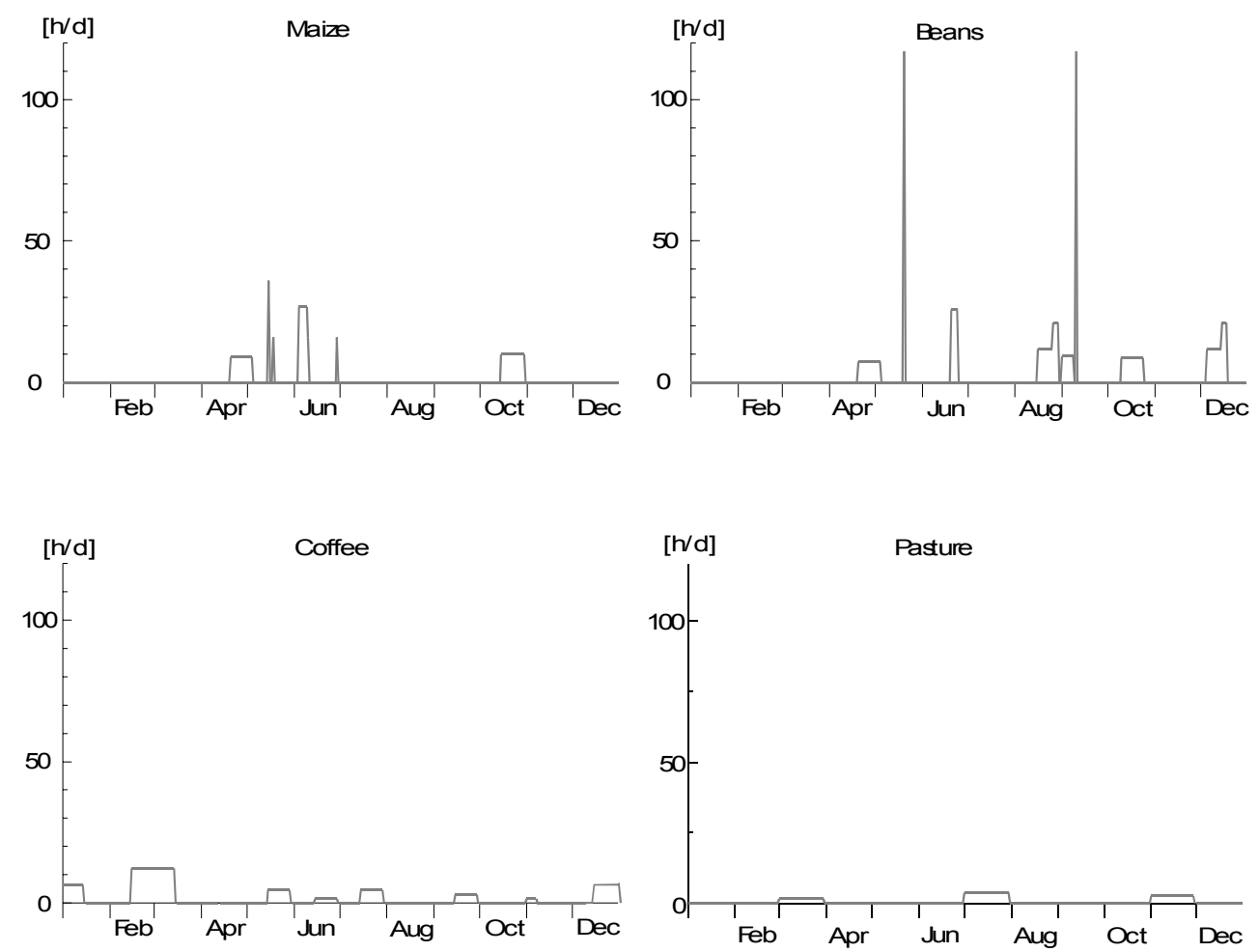

Figure 5.20: Workforce needed for 1 ha monoculture scenarios - peaks. Total labor demand is shown for the four monoculture farms. Bean monoculture has the highest work peaks, which rises up to $120 \mathrm{~h} / \mathrm{ha} * \mathrm{~d}$, corresponding to 15 workers. 

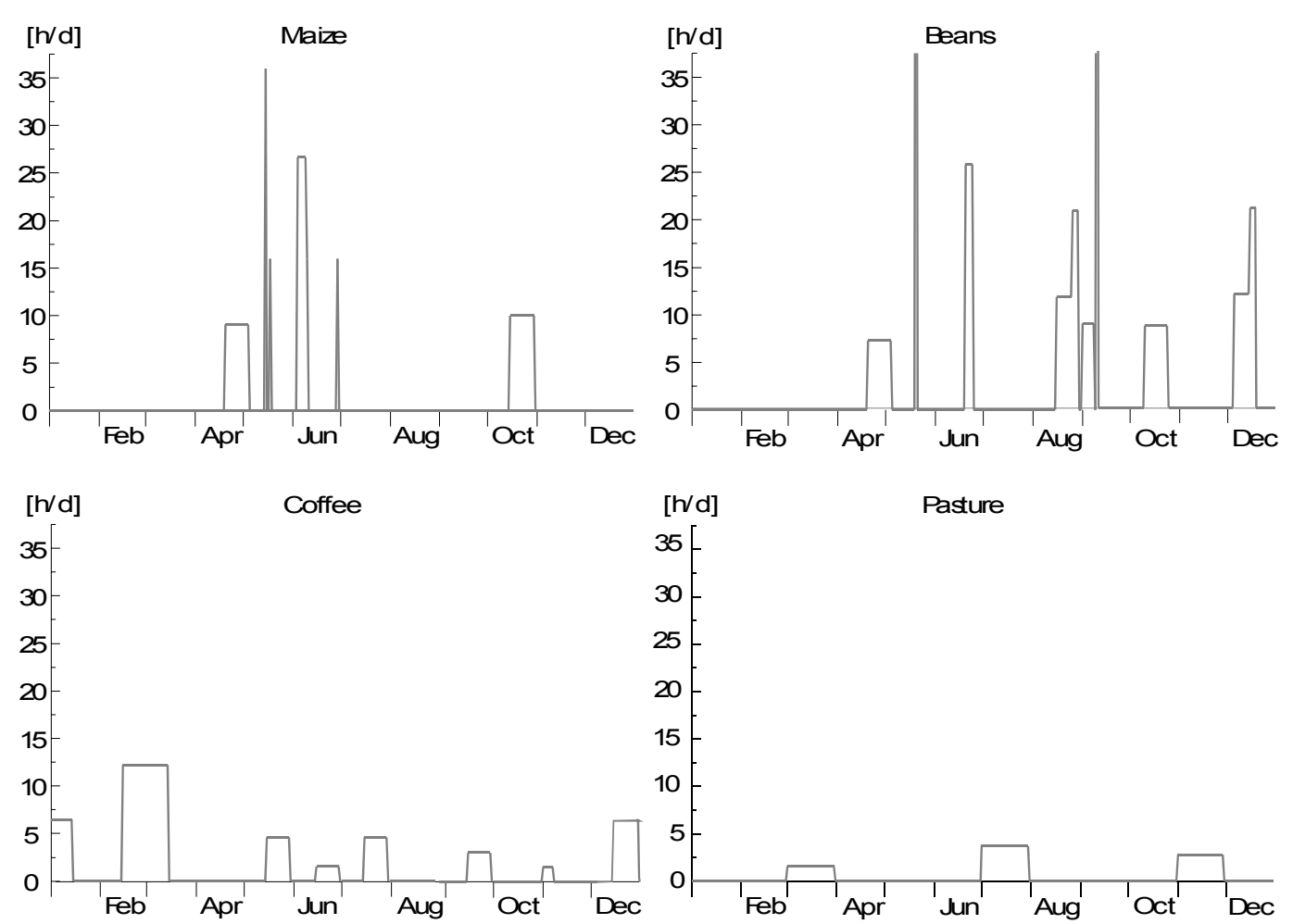

Figure 5.21: Workforce needed for 1 ha monoculture scenarios- resolution. Labor demand apart from work peaks lies in the range of 10-15 h/ha*d for the farm "maize", 12-25 h/ha*d for the farm "beans", 5-12 h/ha*d for the farm "coffee" and 2-5 h/ha*d for the farm "pasture".

With maize, there are two critical periods for workforce shortage. On one hand, there is the day of sowing in May, when the need amounts to $36 \mathrm{~h} / \mathrm{d}$ and 4.5 workers. On the other hand, the period of maize weeding is very work intensive and requires 3.4 workers $(27 \mathrm{~h} / \mathrm{d})$ for eight days. For coffee, work is mainly required for the harvest at the end of the year (less than 8h/d, thus 1 worker) and pruning in February (about 13 $\mathrm{h} / \mathrm{d}, 1.5$ workers). Yet, the latter is often neglected and not carried out by the farmers. Pasture, if we speak of only 1 ha, is never very work intensive. The work peaks for pasture cleaning are minor than $8 \mathrm{~h} / \mathrm{d}$. If farmers burn the pasture, work input is even less.

\subsection{Error propagation}

As the data has a relative broad range of uncertainty, error propagation was carried out in order to estimate the effect of parameter uncertainty on the results. The 
minimum farm was chosen for analysis. As the consumption of sugar, rice and oil have a considerable impact on total calorie consumption they were included. Parameters, for which uncertainty was estimated, are listed in Table 5.4.

\begin{tabular}{lccc}
\hline Parameter & Value & Unit & Estimated Uncertainty \\
\hline Area maize & 0.5 & $\mathrm{ha}$ & $20 \%$ \\
Area beans Primera & 0.25 & $\mathrm{ha}$ & $20 \%$ \\
Area beans Postrera & 0.5 & $\mathrm{ha}$ & $20 \%$ \\
Threshold value of human consumption of maize & 50 & $\mathrm{~kg} / \mathrm{cap}$ & $30 \%$ \\
Threshold value of consumption of beans after & 3.5 & $\mathrm{~kg} / \mathrm{cap}$ & $30 \%$ \\
Primera & & & \\
Threshold value of consumption of beans after & 8 & $\mathrm{~kg} / \mathrm{cap}$ & $30 \%$ \\
Postrera & 0.4 & $\mathrm{~kg} / \mathrm{cap} * \mathrm{~d}$ & $25 \%$ \\
Maximum Consumption Maize & 0.12 & $\mathrm{~kg} / \mathrm{cap} * \mathrm{~d}$ & $25 \%$ \\
Minimum Consumption Maize & 0.2 & $\mathrm{~kg} / \mathrm{cap} * \mathrm{~d}$ & $25 \%$ \\
Maximum Consumption Beans & 0.1 & $\mathrm{~kg} / \mathrm{cap} * \mathrm{~d}$ & $25 \%$ \\
Minimum Consumption Beans & 0.2 & $\mathrm{~kg} / \mathrm{cap} * \mathrm{~d}$ & $30 \%$ \\
Beans stored per cap/d after Primera & 0.2 & $\mathrm{~kg} / \mathrm{cap} * \mathrm{~d}$ & $30 \%$ \\
Beans stored per cap/d after Postrera & 130 & $\mathrm{~kg} / \mathrm{ha}$ & $30 \%$ \\
Nitrogen input of chemical fertilizer & $6 / 4$ & $\mathrm{~kg} / \mathrm{a}$ & $50 \%$ \\
Eggs per hen laying/brooding & 6 & $\mathrm{nr} / \mathrm{brood}$ & $67 \%$ \\
Number of chicken per brood & 36.5 & $\mathrm{~kg} / \mathrm{cap} * \mathrm{a}$ & $30 \%$ \\
Sugar Consumption & 36.5 & $\mathrm{~kg} / \mathrm{cap} * \mathrm{a}$ & $30 \%$ \\
Rice Consumption & 2 & $1 / \mathrm{cap} * \mathrm{a}$ & $30 \%$ \\
Oil Consumption & & \\
\hline
\end{tabular}

Table 5.4: Uncertainties for the minimum farm "staples". Parameters with impact on the assessment criteria calorie supply were chosen for error propagation analysis. The minimum farm "staples" was complemented with sugar, rice and oil consumption, as those three factors have a big effect on total calorie uptake.

The parameters were first varied one by one. Notable reactions of the systems were provoked by the alteration of the area, of fertilizer input and minimum and maximum consumption figures. Variations of threshold values of consumption did, and beans stored per capita did not cause considerable uncertainty margins of the results. In a 
second step, all parameters were modified simultaneously according to Table 5.4. The results of this computation are depicted in Figures 5.22 and 5.23.
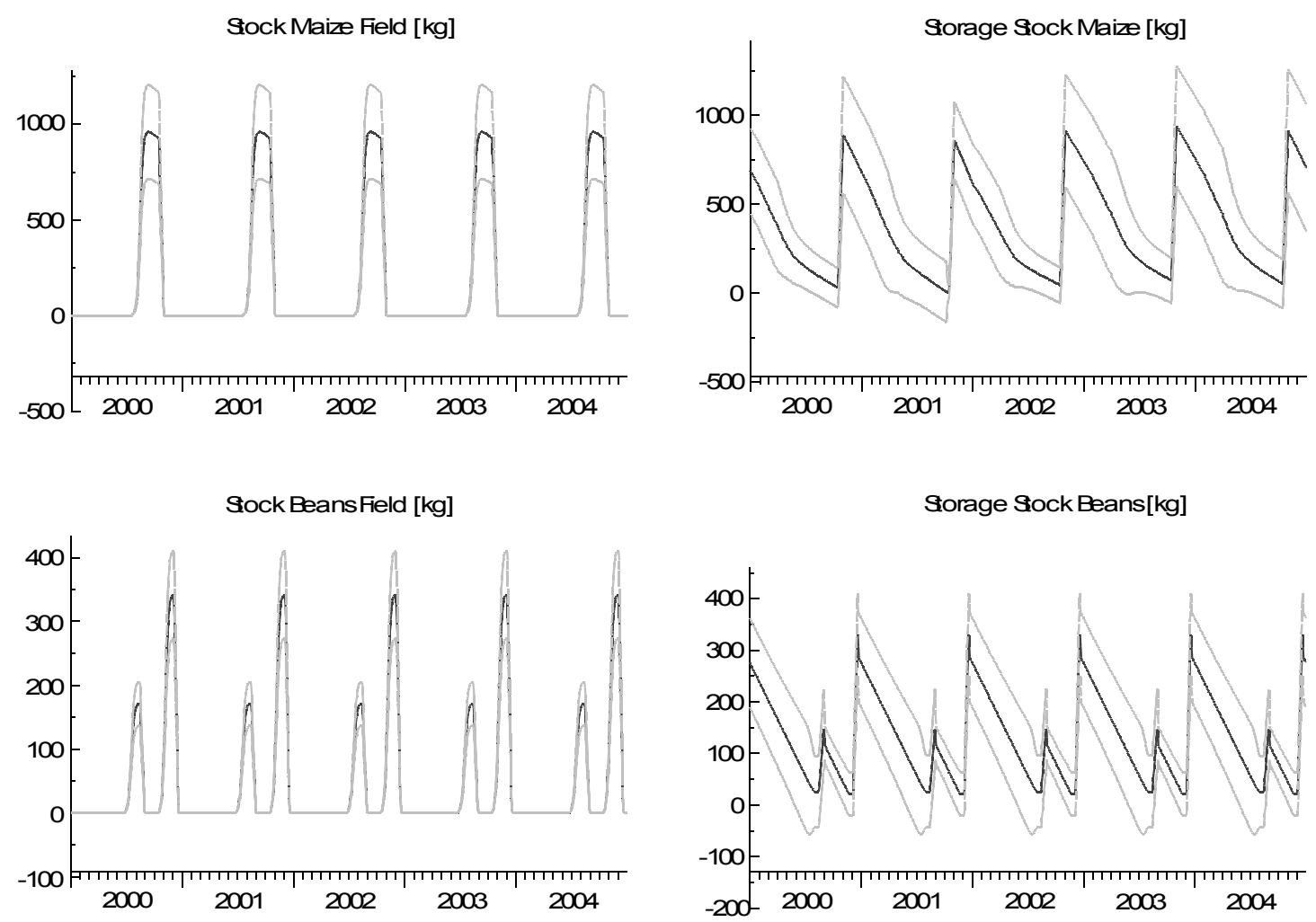

Figure 5.22: Uncertainty margins for minimum farm maize and bean stocks on the field and maize and beans storage stocks. For maize the uncertainty of area and fertilizer nitrogen input amount to an uncertainty margin of $+/-30 \%$ of the stock on the field. For storage stocks this figure lies slightly higher, as in the model maize storage residues of one harvest season are transferred to the following. For beans uncertainty figures lie between $15-20 \%$ of the harvest (see section 5.7).

Figure 5.22 shows the development of stocks, on one hand on the fields and on the other hand in the household (storage stock). For maize the uncertainty of area and fertilizer input figures results in an error margin of about $+/-250 \mathrm{~kg}$, which corresponds to $+/-500 \mathrm{~kg} / \mathrm{ha}$ - roughly a third of the total harvest. Accordingly, the storage stock of the household varies by about $250-350 \mathrm{~kg}$, thus $500-700 \mathrm{~kg} / \mathrm{ha}$. For beans, the stock on the fields diverges by $30 \mathrm{~kg}$ in primera and $60 \mathrm{~kg}$ in postrera, roughly $15-20 \%$ of the total harvest, which results in a higher or lower storage stock. 
Total Calorie Consumption [kcal/cap*d]

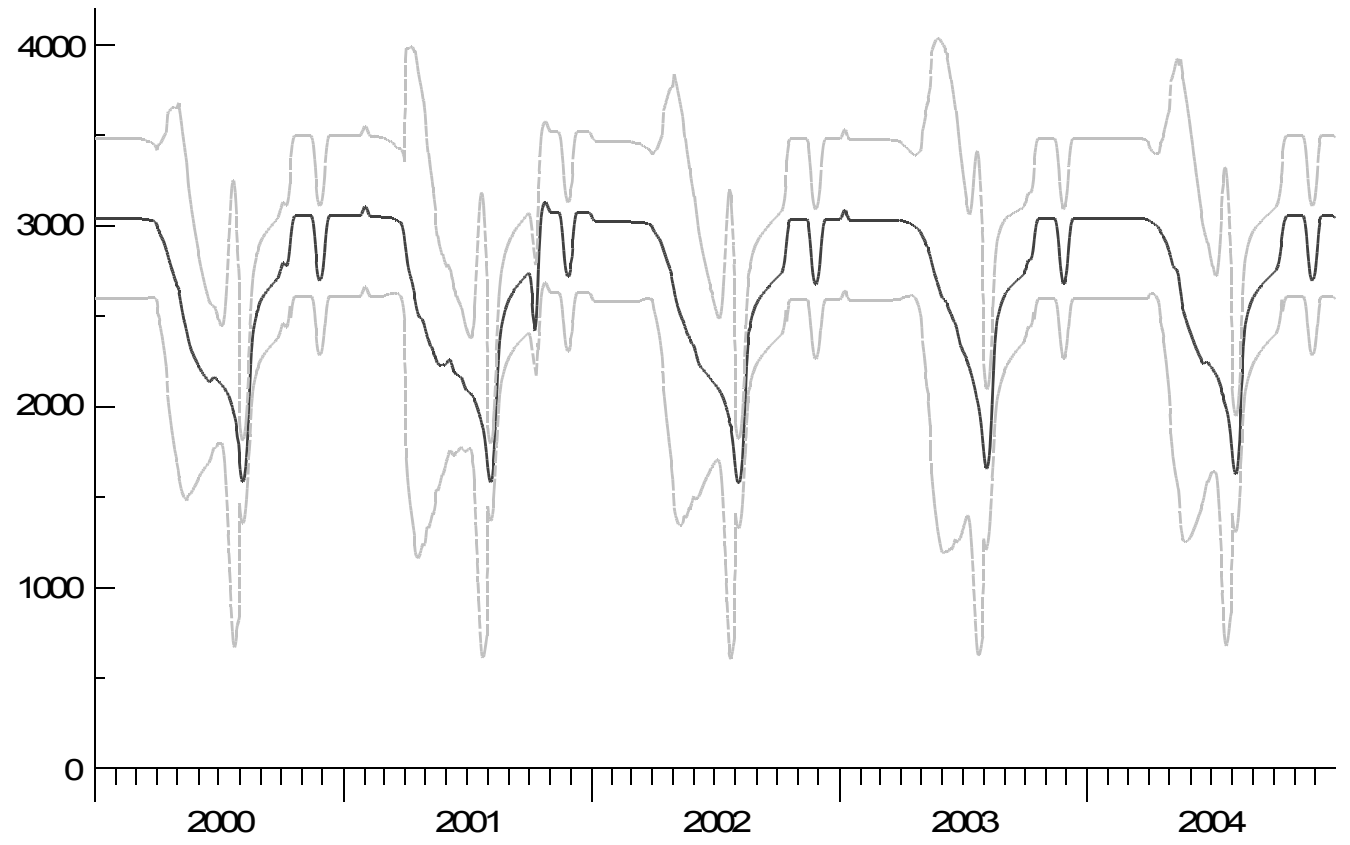

Total Workforce $[\mathrm{h} / \mathrm{d}]$

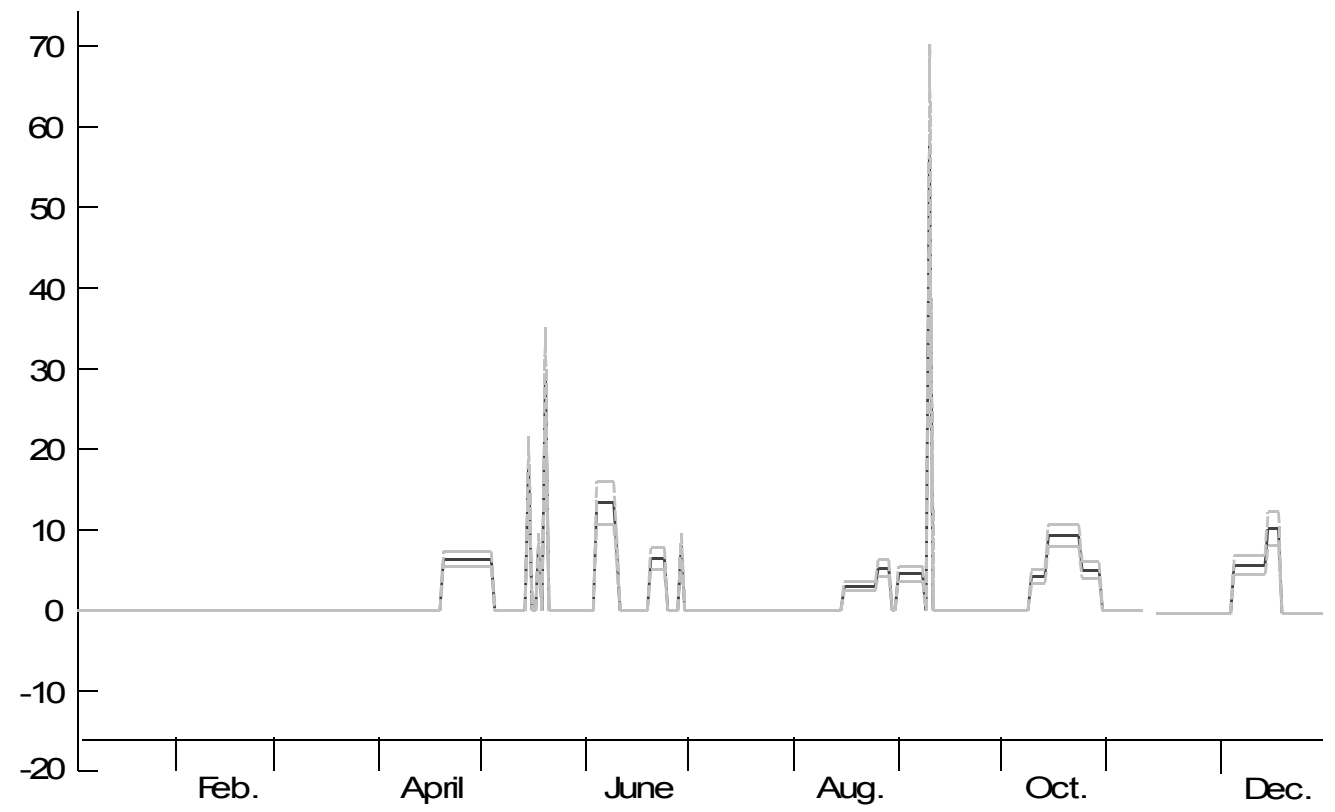

Figure 5.23: Uncertainty margins for assessment criteria total calorie input and total workforce need. Calorie input uncertainty amounts to about $+/-500 \mathrm{kcal} / \mathrm{cap}^{*} \mathrm{~d}$, and lies sometimes even higher. It is mainly due to consumption thresholds. As the parameter consumption lies at the upper limit for the default model, the superior uncertainty margin is not very probable. For workforce uncertainty solely relies on varying area, as uncertainty in labor input (own estimation $+/-30 \%$ ) has not been included. It is therefore small. 
The final uncertainty on assessment criteria varies considerably. In the case of calorie input (Figure 5.23) the uncertainty range amount to about $+/-500 \mathrm{kcal} / \mathrm{cap} * \mathrm{~d}$, about $1 / 6$ of the total. At the upper limit, farmers consume about $3500 \mathrm{kcal} / \mathrm{cap}^{*} \mathrm{~d}$ for about half a year. This figure is rather high and results from the fact that maximum consumption figures assumed are at the upper limit. Therefore the range between the lower uncertainty limit $(2500 \mathrm{kcal})$ and the figures with which the calculations were carried out $(3000 \mathrm{kcal})$ is more reliable.

Total workforce need was varied only with plot size. Thus, the uncertainty range of data describing labor input/ha for the different tasks is not included in the calculations. It may lie as high as $30 \%$.

\subsection{Conclusions}

An agent based model was set up in order to answer the following questions:

1. How can human strategies (e.g. stock management, animal population control, crop mix) for a given system be modeled? What impact do they have on the system?

2. What are the crucial regulation factors of the system?

3. What is the importance of seasonal oscillations of resource availability in an agrarian region of a developing country?

The modeling of human strategies requires profound system knowledge, as data concerning that issue can usually not be gathered directly, but arises rather from discussions with locals and observations. Furthermore, as often there is no unique correct manner of modeling (e.g. Figure 5.7), during the setting-up of the model, different possibilities have to be compared and the more probable one has to be chosen. It is important to calculate with different modeling approaches in order to examine the robustness of a model, as only robust models are reliable.

Nevertheless, it can be stated that farmers' strategies are extremely important for a farming system. Thus, it could be shown that on a farm, where barely the staple self- 
sufficiency was given, half of the minimum needs could be purchased additionally if fertilizer input was increased. Furthermore, labor shortages or periods of otiosity occur if the crop mix is not optimal. Analysis of the strategies also shows that over the years farmers have adapted to the local circumstances. Hence, few of them completely renounce maize cultivation despite the low price of this grain on the market, as maize is crucial for calorie supply and animal holding.

Determining Factors

Goals

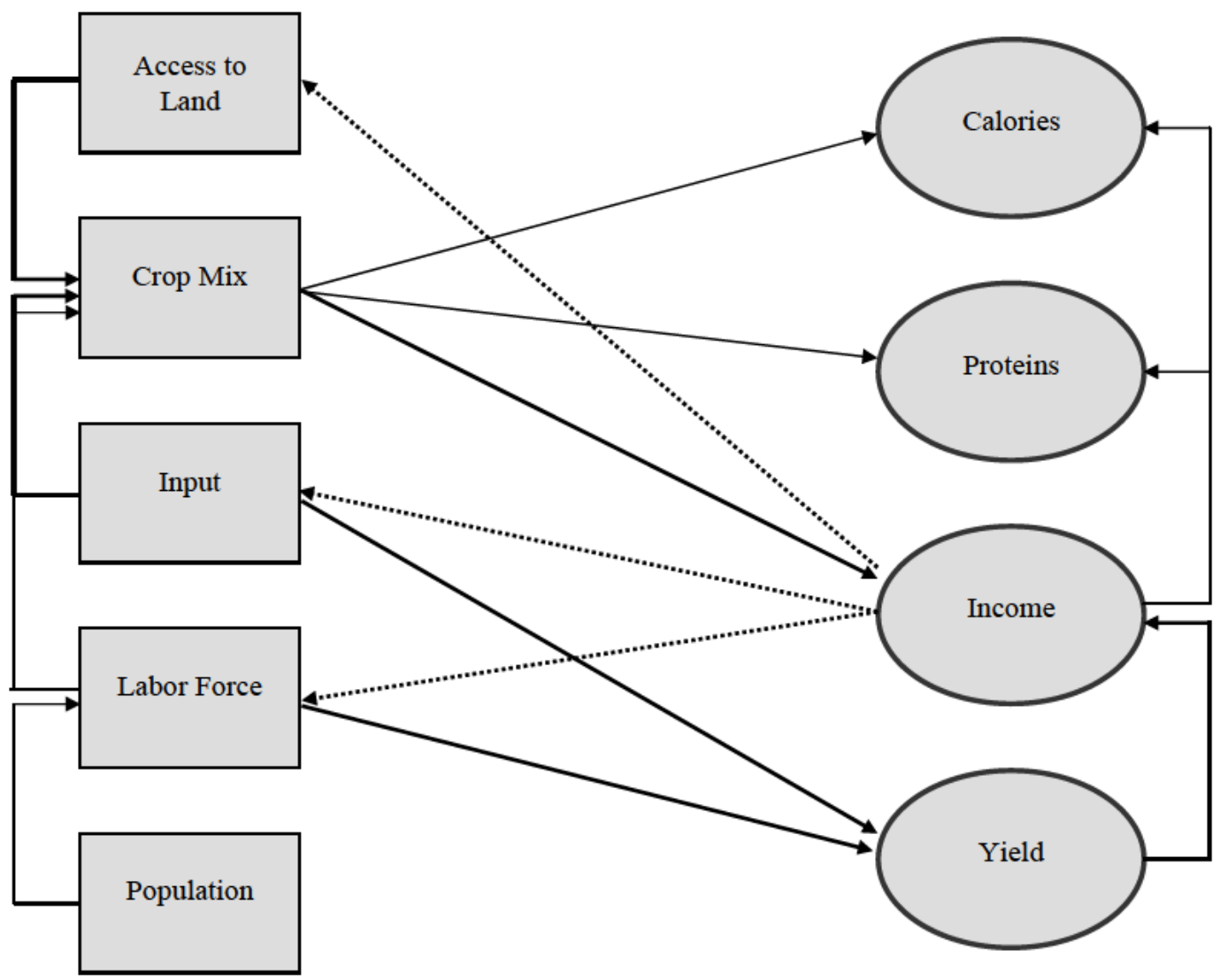

Figure 5.24: Crucial determining factors of the agricultural system: In the modeled system, the goals set by the farmers were supply of calories and proteins, the generation of income. As yield is important for producing surpluses it has been included in this scheme. The crucial determining factors for reaching the goals are access to land, crop mix, input use, labor force and population. Effects of one factor on the other are depicted with arrows. Closed circuits ("virtual or vicious circles") are bold.

The most important regulation factors of the farming system are depicted in Figure 5.24. A crucial role for the supply of calories, protein and income is the crop mix. As shown in section 5.6.2. each crop contributes in another form to the farmers' families 
well-being and security. Yet, the crop choice, which is based on various needs, depends strongly on access to land if self-supply at least of staples is to be assured. It also depends on input and labor force (section 5.6.).

In agricultural systems oriented towards self-supply, the comprehension of seasonal oscillations is essential for their understanding. Thus, food supply, calorie and protein intake, labor offer and demand vary considerably throughout the year. As a result, farmers often take decisions which at first sight may seem illogical. Hence, they may become highly indebted between May and July, in order to purchase foodstuff, inputs and pay workers. Only with dynamic modeling, where we see that food shortages, input purchase and labor shortages occur concurrently, can we comprehend these actions. Another example is the small farmer who sharecrops roughly a third of the little land he manages. According to the results of the dynamic model otherwise he would suffer severe lack of workforce ${ }^{29}$.

In summary, without the knowledge of seasonal constraints and severe supply bottlenecks we do not have an in-depth understanding of the farming systems and thus the region.

\footnotetext{
${ }^{29}$ Remember that small farmers on average have smaller families than the other strata.
} 


\section{6 concLusions}

The method Material Flux Analysis (MFA) has proven to be a good instrument for investigating and modeling agrarian regions in developing countries. MFA is especially convenient, since for system analysis a "common currency", namely physical resources, can be used. Thus, e.g. workforce and input have a price in grain equivalents. Where data is scarce it can be based on information gathered in interviews and literature. That way problematic resource management can be detected without (time) costly measurements. Nevertheless, the carrying out of a MFA requires profound system understanding. An important contribution to the latter was the bottom-up approach chosen for data collection. The face-to-face acquaintance with the farmers' situation and the mutual trust were a good basis for subsequent analyses. Furthermore, it permitted insight into the boundary conditions of the system, which are essential in this context.

With the key factors nitrogen mining, self-sufficiency (including payment of inputs and workforce) for staple crops and energy, and the coverage of the basic and minimum needs, a reasonably good picture of the farming systems could be depicted. Yet, as further explained below, dynamic modeling was a crucial contribution to the understanding of the latter.

The analysis of the main ecological constraints with the given model shows that the region cannot survive on a long term perspective. The main reason for that is rapid population increase and overpopulation of the region, which has made previously sustainable management options (e.g. Milpa system with long bush fallows) unsustainable. Thus, currently forests are cleared and nitrogen is mined out of the soil. Deforesting further results from high firewood needs and the low efficiency of stoves, which are often little more than an open fire. Nitrogen mining is predominantly caused by plant residue burning and improper fertilizer applications. As in this study erosion and leaching were not investigated, it can only be assumed that these two 
factors lead to an even higher nutrient mining in the study region. It can be stated that on farm level there are no considerable differences concerning the range of nutrient mining between farmers' strata. Economic factors like the self-sufficiency for staples and energy and the covering of the basic needs of the different farming systems are tightly linked to access to land. That is because after the drop of the coffee price no high-value product is produced in the region. On a regional scale, on average one job per family would have to be created to allow all farmers' families to cover their basic needs. Theoretically, farming systems could be changed to be more profitable. Yet, beside other conditions this transition would imply a Hinterland with jobs, as it is linked to an exodus of half of the population out of the region.

A more in-depth understanding of the farming systems and their limitations with a focus on seasonal shortcuts could be gained with dynamic modeling. Thus, information about food security, workforce need and farm options can be obtained. That way, supply bottlenecks can be detected and farmers' options understood more thoroughly. Further, with agent-based modeling a new approach was chosen for dynamic MFA modeling. That way the seasonal management of stocks and the corresponding strategies can be investigated.

Dynamic modeling revealed that if a farmer aims at gaining the value of the minimum needs with the production of staples, namely beans, there are periods of workforce shortage. Thus, under the assumed conditions it is not possible to earn the canasta mínima without increasing fertilizer input or employing non-familial workforce. Furthermore, for standardized monoculture farms of one hectare most calories can be produced with the cultivation of maize, while beans lead the protein production and the added value. Coffee and pasture are interesting for complementation, as there are no extreme work peaks and often intensive work periods do not coincide with those of staples. For one hectare farms workforce is limiting only for beans. In summary, with dynamic modeling the importance of diversification could be shown. 


\subsection{Outlook}

As the possibilities of the dynamic model have not been exhausted, next steps may include the extension of the model with harvest oscillations, which are suspected to have a considerable impact on the farming systems. A similar approach may also allow vulnerability and risk assessment for the farms. Furthermore, the model has been set up such that it may be extended with money flows, which might allow the investigation of certain aspects of farmers' strategies. Such an approach would also open a broad range of options for interdisciplinary collaboration. 



\section{ABBREVIATIONS}

\begin{tabular}{|c|c|}
\hline $\mathrm{a}$ & Year \\
\hline Autocons. & Autoconsumption \\
\hline $\mathrm{d}$ & Days \\
\hline B & Big farmers \\
\hline cap. & Capita \\
\hline $\mathrm{CB}$ & Canasta básica \\
\hline cons. & Consumption \\
\hline cov. & Coverage \\
\hline $\mathrm{C} \$$ & Córdoba Oro \\
\hline Dep. & Deposition \\
\hline $\mathrm{DM}$ & Dry matter \\
\hline DSS & Degree of self-sufficiency \\
\hline $\mathrm{DSS}_{\mathrm{B}}$ & Degree of self-sufficiency for beans \\
\hline $\mathrm{DSS}_{\mathrm{E}}$ & Degree of self-sufficiency for energy \\
\hline $\mathrm{DSS}_{\mathrm{M}}$ & Degree of self-sufficiency for maize \\
\hline fam. & Family \\
\hline FAO & Food and Agricultural Organization \\
\hline FS & Farming System \\
\hline GDP & Gross Domestic Product \\
\hline GJ & Giga joules \\
\hline ha & Hectare \\
\hline INEC & Insituto Nacional de Estadísticas y Censos \\
\hline $\mathrm{kg}$ & Kilogram \\
\hline $\mathrm{km}$ & Kilometer \\
\hline LL & Landless farmer \\
\hline lt. & Liter \\
\hline M & Medium farmer \\
\hline m.a.s.l. & Meters above sea level \\
\hline MFA & Mass Flux Analysis \\
\hline Mio. & Millions \\
\hline $\mathrm{mm}$ & Millimeters \\
\hline $\mathrm{N}$ & Nitrogen \\
\hline N-Fix. & Biological nitrogen fixation \\
\hline
\end{tabular}


NGO

$\mathrm{P}$

qq

rel.

$\mathrm{S}$

SWC

$\mathrm{t}$

Transf. Coeff.

UNDP

var.

WG

$\mathrm{X}$
Non-Governmental Organization

Parameter

Quintal

Relative

Small farmer

Soil and water conservation

metric tons

Transfer Coefficient

United Nations Development Program

variation

Waste gases

Variable 


\section{GLOSSARY}

agro forestry

agrisilviculture

A-Horizon

apante

annual crop

autarchy

bean need

canasta básica

canasta mínima

canicula

carrying capacity

cash crop

chemical inputs

department

developing country
Trees mixed with crops.

Trees with pasture and livestock.

The uppermost layers of soils consisting of partly decomposed plant remains and relatively fresh leaves and other plant debris; the surface mineral layer, high in organic matter and dark in color; and the lighter colored layer where leaching of solutes and suspended materials occurs.

Third harvest season. Only in the very humid areas.

Crop living only for one year or less, perpetuating itself by seed.

Self-sufficiency, especially economic self-sufficiency as applied to nations.

Beans needed reach $\rightarrow$ self-sufficiency.

"Consumer basket of basic needs", defined by the author according to information of the locals and assumptions (see appendix E).

"Consumer basket of minimal needs", defined by the author according to information of the locals and assumptions (see appendix E).

Short interception of precipitation pattern with diminished rainfall at the end of July/beginning of August.

The number of people, animals, or crops which a region can support without environmental degradation. A crop produced for its commercial value rather than for use by the grower.

Chemical fertilizer, insecticides, pesticides and herbicides.

Several Nicaraguan municipalities form a department, of which several form a region. A poor (agricultural) country that is seeking to become more advanced economically and socially. 
dual-purpose leguminous crops

farming system

food security

Gramoxone

Hinterland

Human activities

improved fallow

indigenous community

inputs

livelihood

mestizo

Metaland
A pulse which has two purposes. It may thus serves as manure and fodder simultaneously

A population of individual farms that have broadly similar resource bases, enterprise patterns, household livelihoods and constraints, and for which similar development strategies and interventions would be appropriate

"All people, especially the most vulnerable and least resilient have dignified and unthreatening access to the quantity and quality of culturally appropriate food that will fully support the physical, mental, emotional and spiritual health (Oxfam).

Herbicide with the agent paraquat.

All the areas which are necessary for the maintenance of the $\rightarrow$ human activities within a region.

Activities carried out by the humans in order to satisfy their basic needs.

Fallow enriched with fast-growing trees, shrubs or vines in order to accelerate recovery, increase nutrient reserves, and improve the potential for future productivity on the site.

legal association of indigenous people, which officially owns big stretches of land since the days of the Spanish crown.

$\rightarrow$ chemical inputs

The wide and diverse range of activities people do to make their living. These activities are made up of more than jobs (or variations thereof) or economic activities and are designated by work, either in the formal or informal sector. (UNDP)

Human being of mixed European and indigenous descent.

Fictive urban model region of a developed country in a temperate region. 
minifundios
nitrogen mining

N-metabolism

partible inheritance

perennial crop

photosynthate

primera

prune

postrera

process

Region VI

self-sufficiency

sensitivity analysis

sharecropping

staples / staple crops

stocking rate
Very small farm units.

In this study: If the nitrogen balance equation for a process is negative (especially for processes involving soil).

The concept of the metabolism, usually applied to living creatures is here used for regions, describing herewith the turnover of commodities, matter and energy.

Distribution of the land among heirs.

Cultivated plant living for several years.

Sugar or other substance made by photosynthesis

Fist harvest season in Nicaragua. Lasts from May until August.

Trim (a tree, a shrub or a bush) by cutting away dead or overgrown branches or stems, especially to increase fruitfulness and growth.

Second harvest season in Nicaragua. Lasts from September until November or early December.

Transport, transformation and storage of goods or energy.

Nicaragua is divided into regions, which are composed of departments.

As defined in this study: Coming up for autoconsumption and costs of $\rightarrow$ chemical inputs and labor for a specific crop with the revenue of its harvest. Impact of variation of a specific parameter upon the variable.

Arrangement for tenant farmers to rent land, in which a part of the crop is given as the rent. In the study region this is usually half of the harvest.

Main or important crops in terms of consumption of the local population.

Ratio of animals (usually livestock units or tropical livestock units) per ha of pasture. 
stratum

transfer coefficient

transition country

Zona Franca
A level or class to which farmers are assigned according to their land tenure.

The fraction of the total input of indicator $\mathrm{x}$, which is transferred from one process to another or to the stock. The sum of transfer coefficients equals 1 .

A country in conversion from developing to developed country

(Textile) industrial free zone, usually owned by foreign companies, where national laws do not apply. 


\section{GEOGRAPHICAL NAMES}

Bosawás

Esquipulas

Jinotega

Managua

Matagalpa

San Dionisio

Sébaco

Susulí
Protected rainforest area in the northeast of Nicaragua.

Borders the Atlantic Coast.

Small town in the Central Highlands close to the study area San Dionisio.

Northern Nicaraguan department and capital of the department. Famous for its coffee.

Capital of Nicaragua. Lies in the Pacific Region.

Northern Nicaraguan department and capital of the department.

Municipality and municipal capital.

"Knotenpunkt" between the cities Managua, Matagalpa and Estelí. Lies at the Panamerican Highway. Region is famous for its vegetables.

Community of the municipality of San Dionisio, where this study was carried out. 


\section{BIBLIOGRAPHY}

Alfsen, K.H., De Franco, M., Glomsrød, S., Johnsen T., 1996: The cost of soil erosion in Nicaragua. Ecological Economics 16, pp. 129-145.

Artola González et al, 1997: Apuntes para una Estrategia de Desarrollo Rural. Nitlapán, Universidad Centroamericana, Managua, Nicaragua.

Artola, N., 1998: Ganadería: Hay que apostar por otro modelo? Envío, Octubre 1998. Universidad Centroamericana (UCA), Managua, Nicaragua.

Austin, J., Fox, J., Kruger, W., 1985: The Role of the Revolutionary State in the Nicaraguan Food System. World Development, 13(1), pp. 15-40.

Baccini, P., Bader, H.-P., 1996: Regionaler Stoffhaushalt. Spektrum Akademischer Verlag, Heidelberg.

Baccini, P., Brunner, P., 1991: Metabolism of the Antroposphere. Springer Verlag, Berlin.

Baltodano, M.E., Tijerino, D., Vernooy, R., 1997: Proceso de identificación y características de la sub-cuenca del río Calico - San Dionisio, Matagalpa. In: Proyecto CIAT Laderas América Central. Reportes de progreso 1997. Centro Internacional de Agricultura Tropical, Managua, Nicaragua.

Bernet, T., Staal, S., Walker, T., 2001: Changing Milk Production Trends in Peru. Small-Scale Highland Farming versus Coastal Agrobusiness. Mountain Research and Development, 21(3), pp. 268275.

Binder, C., 1996: The Early Recognition of Environmental Impacts of Human Activities in Developing Countries. Diss. ETH Nr. 11748, Eidgenössische Technische Hochschule Zürich, Zürich, Switzerland.

Birchenall, J.A., 2001: Income distribution, human capital and economic growth in Colombia. Journal of Developmental Economics, 66, pp. 271-287.

Boserup, E., 1965: The conditions of agricultural growth: The economics of agrarian change under population pressure. Aldine, Chicago, Illinois. 
Brown, L., 1997: The Agricultural Link: How Environmental Deterioration Could Disrupt Economic Progress. Worldwatch Paper 136, Washington D.C.

Brown, L.R., 1996: Tough Choices. Facing the Challenge of Food Scarcity. Worldwatch Environmental Alert Series. W.W. Norton \& Company, New York, USA.

Bundesamt für Landwirtschaft, 2001: www.blw.admin.ch/fakten/statistik/d/tabelle_10.pdf

Calderón, S., Leemann, E., Bachmann, F., 2001: Taller de Aprendizaje Autodidacta para la Gestión y el Manejo Sostenible de los Recursos Naturales. Memoria del Taller. ETHZ, Zürich, Switzerland.

Cherrett, I., 2001: Decentralization, Rural Poverty, and Degradation of Uplands in Central America. Mountain Research and Development, 21(3), pp. 221-225.

Corral, L., Reardon, T., 2001: Rural Nonfarm Incomes in Nicaragua. World Development, 29(3), pp. 427-442.

Davis, B., Carletto, C., Piccioni, N., 2001: Income generation strategies among Nicaraguan agricultural producers. In: Land and sustainable livelihood in Latin America, Zoomers, A. (ed.), pp. 169-187. Royal Tropical Institute, Amsterdam, Netherland.

De Jager, A., Onduru, D., van Wijk, M.S., Vlaming, J., Gachini, G.N., 2001: Assessing sustainability of low-external-input farm management systems with the nutrient monitoring approach : a case study in Kenya. Agricultural Systems, 69, pp. 99-118.

Dixon, J., Gulliver, A., Gibbon, D., 2001: Farming Systems and Poverty. FAO and World Bank, Rome and Washington D.C.

Drechsler, P., et al, 2001: Population density, soil nutrient depletion, and economic growth in subSaharan Africa. Ecological Economics, 38, pp. 251-258.

Elias, E., Morse, S., Belshaw, D.G.R., 1998: Nitrogen and phosphorus balances of Kindo Koisha farms in southern Ethiopia. Agriculture, Ecosystems and Environment, 71, pp. 93-113.

Espinoza, N., Vernooy, R., 1998: Las 15 micro-cuencas del Río Calico, San Dionisio, Matagalpa. Mapeo y análisis participativos de los recursos naturales. Centro Internacional de Agricultura Tropical, Proyecto Laderas, Centroamérica. 
Faist, M., 2001: Ressourceneffizienz in der Aktivität Ernähren. Diss. ETH Nr. 13884. Eidgenössische Technische Hochschule Zürich, Zürich, Switzerland.

Fang, C., Zhang, X., Fan, S., 2002: Emergence of urban poverty and inequality in China: evidence from household survey. China Economic Review, 13, pp. 430-443.

FAO, 1995: Apoyo a las organizaciones de los pequeños productores para la comercialización de granos básicos. Franja granífera San Ramón-Esquipulas. Vol $1+2$. MAGFOR / FAO, Managua, Nicaragua.

FAO, 2001: FAO - Perfiles nutricionales por países: Nicaragua. FAO, Rome, 2001.

FAO, 2002: Food Balance Sheet for Nicaragua (Average 1998-2000). FAOSTAT.

http://apps.fao.org/default htm.

Fiallos, A., 2002: Nicaragua. Principales Problemas y Limitaciones del Sector Agrícola y Rural. Seminario Interno: Situación y perspectivas para el desarrollo agrícola y rural en Centroamérica y Panamá en la primera década del siglo XXI. Santiago, Chile, 12 al 14 febrero de 2002. FAO, Oficina Regional para América Latina y el Caribe.

Fischer, G. et al, 2001: Global Agro-ecological Assessment for Agriculture in the $21^{\text {st }}$ Century. IIASA, Vienna, Austria \& FAO, Rome, Italy.

FIVIMS, 2003: http://www fivims.org/index.jsp, 06.01.03, key words: Nicaragua, vulnerability, nutrition, soil, food insecurity, cereal crops.

Flores, M. et al, 2002: Centroamérica: El impacto de la caída de los precios del café. Serie estudios y perspectivas 9. CEPAL, México D.F.

Folmer, E.C.R., Geurts, P.M.H., Francisco, J.R., 1998: Assessment of soil fertility depletion in Mozambique. Agriculture, Ecosystems and Environment, 71, pp. 159-167.

Gerbens-Leenes, P.W., Nonhebel, S., 2002: Consumption patterns and their effects on land required for food. Ecological Economics, 42, pp. 185-199.

Gerbouin, P., 2002: personal communication. PRODESSA, Matagalpa, Nicaragua. 
Godoy, R., Hockenstein, J., 1992: Agricultural Research Bias in Nicaragua: The Case of Beans. World Development, 20(11), pp. 1685-1696.

Gregory, P.J., Ingram, J.S.I., 2000: Global change and food and forest production: future scientific challenges. Agriculture, Ecosystems and Environment, 82, pp. 3-14.

Harris, J.M., Kennedy, S., 1999: Carrying capacity in agriculture: global and regional issues. Ecological Economics 29, pp. 443-461.

Holt-Giménez, E., 2002: Measuring farmers' agroecological resistance after Hurricane Mitch in Nicaragua: a case study in participatory, sustainable land management impact monitoring. Agriculture, Ecosystem and Environment, 93, pp. 87-105.

Howard, S., 1998: Land conflict and Mayangna territorial rights in Nicaragua’s Bosawás reserve. Bull. Latin. Am. Res., 17(1), pp. 17-34.

Hug, F., 2002: Ressourcenhaushalt alpiner Regionen und deren physiologische Interaktionen mit den Tiefländern im Kontext einer nachhaltigen Entwicklung. Diss. ETH Nr. 14540. Eidgenössische Technische Hochschule Zürich, Zürich, Switzerland.

INEC, 2003: www.inec.gob.ni/estadisticas/estadisticas htm, 10.02.03.

INIFOM, 04.09.02: www.inifom.gob.ni/Caracter/Informacion/Matagalpa/SanDionisio htm

IPCC, 2001: Climate Change 2001: Impacts, Adaptation and Vulnerability. Technical Summary. Cambridge University Press, Cambridge, UK.

Kaoneka, A.R.S., Solberg, B., 1997: Analysis of deforestation and economically sustainable farming systems under pressure of population growth and income constraints at the village level in Tanzania. Agriculture, Ecosystems and Environment, 62, pp. 59-70.

Leemann, E. and Scheidegger, R., 2002: Mapa general SUSULI, Micro-Cuenca del Río Calíco, Municipio San Dionisio, 2000. ETHZ, Zürich, Switzerland.

Leemann, E., 2002: Personal communication. University of Zürich, Switzerland

Leemann, E., forthcoming: Ph.D. thesis, University of Zürich, Switzerland. 
Leemann, E., Scheidegger, R., 2002: Mapa general SUSULÍ, Micro-Cuenca del Río Calíco, Municipio San Dionisio, 2000, Chair of Resource and Waste Management, Swiss Federal Institute of Technology, Zürich, Switzerland.

Maingi, J.M., Shisanya, C.A., Gitonga, N.M., Hornetz, B., 2001: Nitrogen fixation by common bean (Phaseolus vulgaris L.) in pure and mixed stands in semi-arid south-east Kenya. European Journal of Agronomy, 14, pp. 1-12.

Maldidier, C., Antillón, T., Artola, N., Ruiz, A., Castillo, K., 1997: Deforestación y frontera agrícola en Nicaragua. Cuadernos CRIES 2, CRIES, Managua, Nicaragua.

Morris, S.S., et al., 2002: Hurricane Mitch and the Livelihoods of the Rural Poor in Honduras. World Development, 30(1), pp. 49-60.

Müller D.B., 1998: Modellierung, Simulation und Bewertung des regionalen Holzhaushaltes, Diss. ETH Zürich Nr. 12990, Swiss Federal Institute of Technology, Zürich, Switzerland

Nandwa, S.M. and Bekunda, M.A., 1998: Research on nutrient flows and balances in East and Southern Africa. state-of-the-art. Agriculture, Ecosystems and Environment, 71, pp. 5-18.

Nitlapán-UCA, 1995: Diagnóstico de la producción agropecuaria en el interior del país. Análisis de Encuesta Rural 1995. Universidad Centroamericana, Managua, Nicaragua.

Orozco, P.P., 2000 and 2001: Personal communication. CIAT-Laderas, San Dionisio, Nicaragua.

Pagel, H., Enzmann, J., Mutscher, H., 1982: Pflanzennährstoffe in tropischen Böden - ihre Bestimmung und Bewertung. Deutscher Landwirtschaftsverlag Berlin.

Pinstrup-Andersen, P., Pandya-Lorch, R., 1994: Alleviating Poverty, Intensifying Agriculture, and Effectively Managing Natural Resources. Food Agriculture, and the Environment Discussion Paper 1, International Food Policy Research Institute, Washington D.C., August 1994.

Pinstrup-Andersen, P., Pandya-Lorch, R., Rosegrant, M.W., 1997: The World Food Situation: Recent Developments, Emerging Issues, and Long-Term Prospects. Food Policy Report. International Food Policy Research Institute, Washinton D.C., December 1997.

Posner, J.L. and McPherson, M.F., 1982: Agriculture on the Steep Slopes of Tropical America: Current Situation and Prospects for the Year 2000. World Development, 10(5), pp. 341-353. 
Real, M.G., 1998: A methodology for evaluating the metabolism in the large scale introduction of renewable energy systems. Diss ETH Nr. 12937. Eidgenössische Technische Hochschule Zürich, Zürich, Switzerland.

Redle, M., 1999: Kies- und Energiehaushalt urbaner Regionen in Abhängigkeit der Siedlungsentwicklung. Diss. ETH Nr. 13108. Eidgenössische Technische Hochschule Zürich, Zürich, Switzerland.

Rivas, S., 2000: Ein agro-ökologisches regionalisiertes Modell zur Analyse des Brennholzversorgungssystems in Entwicklungsländern. Institut für Energiewirtschaft und rationelle Energieanwendung. Universität Stuttgart.

Rocha, J.L., 2001: Crónica del café: historias, responsables, interrogantes. Envío, Agosto 2001, pp.

Rodríguez Ibarra, I., 2001: Personal communication. Universidad Nacional Agraria (UNA), Managua, Nicaragua.

Schrader, K., 2002: Anreize zur nachhaltigen Bodennutzung in Zentralamerika. Eine Analyse direkter materieller Anreize in Projekten der ländlichen Regionalentwicklung in Bergregionen El Salvadors, Honduras' und Nicaraguas. Geographica Bernensia, G 69, Geographisches Institit Bern, Bern, Schweiz.

SETEC, 2001: Estrategia reforzada de crecimiento económico y reducción de pobreza. Gobierno de Nicaragua, Managua.

Shriar, A.J., 2002: Food security and land use deforestation in northern Guatemala, Food Policy 27, pp. 395-414.

Smith, L.C. et al., 2000: The geography and causes of food insecurity in developing countries. Agricultural Economics, 22, pp. 199-215.

Soto-Pinto, L., Perfecto, Y., Castillo-Hernandez, J., Caballero-Nieto, J., 2000: Shade effect on coffee production at the northern Tzeltal zone of the state of Chiapas, Mexico. Agriculture, Ecosystems and Environment, 80, pp. 61-69.

Spoor, M., 1995: Liberalization of grain markets in Nicaragua, Food Policy 20(2), pp. 99-110.

Stiglitz, J., 2002: Globalization and its discontents. Allen Lane The Penguin Press. 
Tiffen, M., Mortimore, M., Gichuku, F., 1994: More people, less erosion : environmental recovery in Kenya. Wiley, Chichester, UK.

UN Habitat, 2002: http://www.unhabitat.org/programmes/guo/guo_databases.asp

UNDP, 2000: El Desarrollo Humano en Nicaragua 2000.

http://www.pnud.org ni/idhnicaragua/index.htm.

United States Department of Agriculture, 2003: http://www.aphis.usda.gov/oa/pubs/fsend.html, 09.01 .03

van den Bosch, H., Gitari, J.N., Ogaro, V.N., Maobe, S., Vlaming, J., 1998: Monitoring nutrient flows and economic performance in African farming systems (NUTMON). III. Monitoring nutrient flows and balances in three districts in Kenya. Agriculture, Ecosystems and Environment, 71, pp. 5380 .

van Vuuren, D.P., Smeets, E.M.W., 2000: Ecological footprints of Benin, Bhutan, Costa Rica and the Netherlands. Ecological Economics 34(1), pp. 115-130.

Veihe, A., Rey, J., Quinton, J.N., Strauss, P., Sancho, F.M., Somarriba, M., 2001: Modelling of event-based soil erosion in Costa Rica, Nicaragua and Mexico: evaluation of the EUROSEM model. Catena, 44, pp. 187-203.

von Steiger, B., Baccini, P., 1990: Regionale Stoffbilanzierung von landwirtschaftlichen Böden mit messbarem Ein- und Austrag. Bericht 38 des Nationalen Forschungsprogramms "Boden", LiebefeldBern.

WCED, 1987: Our Common Future. World Commission on Environment and Development (WCED), Oxford University Press, Oxford and New York.

Webster, C.C., Wilson, P.N. (ed.), 1998: Agriculture in the Tropics. Blackwell Science, Oxford, UK.

WEC/FAO, 1999: The Challenge of Rural Energy Poverty in Developing Countries. WEC/FAO, London.

Wortmann, C.S. and Kaizzi, C.K., 1998: Nutrient balances and expected effects of alternative practices in farming systems of Uganda. Agriculture, Ecosystems and Environment, 71, pp. 115-129. 
Zeleke, G., Hurni, H., 2001: Implications of Land Use and Land Cover Dynamics for Mountain Resource Degradation in the Northwestern Ethiopian Highlands. Mountain Research and Development, 21(2), pp. 184-191. 


\section{APPENDICES}

APPENDIX A

APPENDIX B

APPENDIX C

APPENDIX D

APPENDIX E

APPENDIX F
MATHEMATICAL MODEL

DATA, CALCULATIONS AND ASSUMPTIONS FOR THE QUASI-STATIONARY MODEL

PARAMETER STRATA

PRICES

THE CONCEPT OF THE CANASTA BÁSICA - BASIC NEEDS DYNAMIC MODEL 


\section{Appendix A: Mathematical Model for the Quasi-Stationary Model}

\section{Model Setup}

- 7 Processes (4 internal, 3 external)

-22 Fluxes

\section{VARIABLES}

\section{Stocks}

$\mathrm{G}_{1}(\mathrm{t})=$ Staple Production

$\mathrm{G}_{2}(\mathrm{t})=$ Animal Production

$\mathrm{G}_{3}(\mathrm{t})=$ Coffee + Forest

$\mathrm{G}_{4}(\mathrm{t})=$ Farmer's Household

\section{Stock Changes}

$\dot{\mathrm{G}}_{1}(\mathrm{t})=$ Staple Production

$\dot{\mathrm{G}}_{2}(\mathrm{t})=$ Animal Production

$\dot{\mathrm{G}}_{3}(\mathrm{t})=$ Coffee + Forest

$\dot{\mathrm{G}}_{4}(\mathrm{t})=$ Farmer's Household

\section{Fluxes}

$\mathrm{A}_{12}=$ Fodder for chicken and pigs

$\mathrm{A}_{14}=$ Staples autoconsumption

$\mathrm{A}_{15}=$ Sold staples and wages

$\mathrm{A}_{16}=$ Waste gas (burning of plant material and fertilizer loss)

$\mathrm{A}_{24}=$ Animal products for autoconsumption (Eggs, Chicken meat and milk)

$\mathrm{A}_{25}=$ Animal products sold (milk) and animals (pigs, male calves and cows)

$\mathrm{A}_{26}=$ Abluft cow and horse manure and waste gas from pasture burning

$\mathrm{A}_{27}=$ Chicken and pig manure

$\mathrm{A}_{34}=$ Firewood

$\mathrm{A}_{35}=$ Coffee

$\mathrm{A}_{37}=$ Coffee Husk

$\mathrm{A}_{42}=$ Household waste and whey

$\mathrm{A}_{46}=$ Abluft firewood burning

$\mathrm{A}_{47}=$ Human excrements and ash

$\mathrm{A}_{51}=$ Fertilizer staples

$\mathrm{A}_{52}=$ Purchased animals (piglets)

$\mathrm{A}_{53}=$ Fertilizer coffee

$\mathrm{A}_{54}=$ Purchased food (mainly rice and sugar)

$A_{61}=$ Nitrogen deposition and nitrogen fixation (staples) 
$A_{62}=$ Nitrogen deposition (pastures)

$A_{63}=$ Nitrogen deposition (coffee and forest)

$\mathrm{A}_{74}=$ Purchased firewood

\section{PARAMETERS}

a) Number of Inhabitants: I

b) Areas

- $\mathrm{F}_{\mathrm{M}}$ : Area on which maize is grown

- $\mathrm{F}_{\mathrm{B}}$ : Area on which beans are grown

- $\mathrm{F}_{\mathrm{F}}$ : Area of fallow

- $\mathrm{F}_{\mathrm{p}}$ : Pasture area

- $\mathrm{F}_{\mathrm{C}}$ : Area of coffee growing and coffee forest

- $\mathrm{F}_{\mathrm{W}}$ : Area of natural forest

c) Animals:

- Chicken and Hens: H

$\mathrm{H}_{\mathrm{L}}$ : ratio grown-up hens/total chicken

$\mathrm{H}_{\mathrm{S}}$ : Hens or chicken sold

$\mathrm{H}_{\mathrm{P}}$ : Hens or hicken purchased

- Pigs: $\mathrm{P}$

$\mathrm{P}_{\mathrm{S}}$ : Pigs sold

$P_{\mathrm{P}}$ : Pigs purchased

$\mathrm{L}_{\mathrm{S}}$ : Piglets sold

$\mathrm{L}_{\mathrm{P}}$ : Piglets purchased

- Horses and mules: E

Es: Horses/mules sold

$\mathrm{E}_{\mathrm{p}}$ : Horses/mules purchased

- Cows: $\mathrm{K}$

$\mathrm{K}_{\mathrm{L}}$ : Ratio adult cows/total cows

$\mathrm{K}_{\mathrm{S}}$ : Cow sold

$\mathrm{K}_{\mathrm{P}}$ : Cows purchased

$\mathrm{V}_{\mathrm{S}}$ : Calves sold

$\mathrm{V}_{\mathrm{p}}$ : Calves purchased

d) Other Parameters

$\mathrm{B}_{1} \quad=$ Maize yield $[\mathrm{kg} / \mathrm{ha} *$ growth period $]$

$\mathrm{B}_{2}=$ Bean yield $\left[\mathrm{kg} / \mathrm{ha}^{*}\right.$ growth period $]$

$\mathrm{B}_{3}=$ Seed maize $[\mathrm{kg} / \mathrm{ha}]$

$\mathrm{B}_{4}=$ Seed beans $[\mathrm{kg} / \mathrm{ha}]$ 
$\mathrm{B}_{5} \quad=$ Average maize consumption $[\mathrm{kg} /$ pers $* \mathrm{~d}]$

$\mathrm{B}_{6} \quad=$ Average bean consumption $[\mathrm{kg} /$ pers*d]

$\mathrm{B}_{7}=$ Transfercoefficient for $\mathrm{N}$ to the air when burning

$\mathrm{B}_{8}=$ Ratio harvest maize (grains) $/$ plant material

$\mathrm{B}_{9} \quad=$ Ratio harvest beans / plant material

$\mathrm{B}_{10}=$ Fertilizer application maize $[\mathrm{kg} / \mathrm{ha}$ * growth period $]$

$\mathrm{B}_{11}=$ Fertilizer application beans $[\mathrm{kg} / \mathrm{ha} *$ growth period $]$

$\mathrm{B}_{12}=$ Fertilizer loss through volatilization $\left(\mathrm{NH}_{3}\right)$ as ratio of application $[\mathrm{kg} / \mathrm{ha}$ *a]

$B_{13}=$ N-Deposition $\left(\mathrm{NH}_{3}\right)[\mathrm{kg} \mathrm{N} / \mathrm{ha} * \mathrm{a}]$

$\mathrm{B}_{14}=\mathrm{N}-$ Fixation $[\mathrm{kg} \mathrm{N} / \mathrm{ha} *$ growth Period $]$

$\mathrm{B}_{15}=$ Average maize consumption per hen and day

$\mathrm{B}_{16}=$ Average days per year hens are fed with maize

$\mathrm{B}_{17}=$ Average maize consumption per pig $[\mathrm{kg} / \mathrm{cap} * \mathrm{~d}]$

$\mathrm{B}_{18}=$ Duration of pig mast (days)

$\mathrm{B}_{19}=$ Average mumber of eggs per hen and year

$\mathrm{B}_{20}=$ Number of broods per brooding hen/year

$\mathrm{B}_{21} \quad=$ Ratio brooding hen/total hens

$\mathrm{B}_{22}=$ Eggs not laid because of offspring per brood

$\mathrm{B}_{23}=$ Mass of egg

$\mathrm{B}_{24}=$ Mass of chicken

$\mathrm{B}_{25}=$ Number of surviving chicken per brood

$\mathrm{B}_{26}=$ Rate of offspring per cow and year

$\mathrm{B}_{27}=$ Average milk production per cow [lt/cap*d] (during the days it gives milk)

$\mathrm{B}_{28} \quad=$ Number of days of milk production

$\mathrm{B}_{29}=$ Ratio autoconsumption milk

$\mathrm{B}_{30}=$ Average weight of a piglet $[\mathrm{kg}]$

$\mathrm{B}_{31}=$ Average weight of an adult pig $[\mathrm{kg}]$

$\mathrm{B}_{32}=$ Average weight of a calf $[\mathrm{kg}]$

$\mathrm{B}_{33}=$ Average weight of a cow $[\mathrm{kg}]$

$\mathrm{B}_{34}=$ Average weight of a horse $[\mathrm{kg}]$

$\mathrm{B}_{35}=$ Fodder consumption/Cow*d $\left[\mathrm{kg} \mathrm{DM} / \mathrm{cow}^{*} \mathrm{~d}\right]$

$\mathrm{B}_{36}=$ Days of fodder consumption/pasture (sufficient food quality and quantity)

$\mathrm{B}_{37}=\mathrm{N}$-volatilization factor from manure

$\mathrm{B}_{38}=\mathrm{N}$-Utilization factor of cow

$\mathrm{B}_{39}=$ Correction factor cow/horse for $\mathrm{N}$-Losses

$\mathrm{B}_{40}=$ Share of pasture area burnt

$\mathrm{B}_{41}=$ Plant material on pasture plots when burning $[\mathrm{kg} / \mathrm{ha}]$

$\mathrm{B}_{42}=$ Average manure per pig $[\mathrm{kg} / \mathrm{pig} * \mathrm{a}]$

$\mathrm{B}_{43}=$ Average manure per chicken $/ \mathrm{hen}[\mathrm{kg} / \mathrm{hen} * \mathrm{a}]$

$\mathrm{B}_{44}=$ Houshold food waste [kg DM/fam*a]

$\mathrm{B}_{45}=$ Ratio protein of milk remaining in whey 
$\mathrm{B}_{46}=$ Firewood consumption off the own farm (ratio of total firewood consumption)

$\mathrm{B}_{47}=$ Firewood consumption $/$ family $[\mathrm{kg} /$ family*a $]$

$\mathrm{B}_{48}=$ Coffee yield $\left[\mathrm{kg} / \mathrm{ha}{ }^{*} \mathrm{a}\right]$

$\mathrm{B}_{49}=$ Ratio Coffee / Husk

$\mathrm{B}_{50}=$ Fertilizer application coffee $\left[\mathrm{kg} / \mathrm{ha}{ }^{*} \mathrm{a}\right]$

$\mathrm{B}_{51} \quad=\mathrm{N}$ excretion per person $[\mathrm{kg} / \mathrm{cap} * \mathrm{~d}]$

$\mathrm{B}_{52}=$ Average rice consumption $[\mathrm{kg} / \mathrm{cap} * \mathrm{~d}]$

$\mathrm{B}_{53}=$ Days of rice consumption per year

$\mathrm{B}_{54}=$ Average sugar consumption $[\mathrm{kg} / \mathrm{cap} * \mathrm{~d}]$

$\mathrm{B}_{55}=$ Days of sugar consumption per year

$\mathrm{B}_{56}=$ Ratio of maize land used for sharecropping

$\mathrm{B}_{57}=$ Conditions of sharecropping (part given to partner) with maize

$\mathrm{B}_{58}=$ Ratio of bean land used for sharecropping

$\mathrm{B}_{59}=$ Conditions of sharecropping (part given to partner) with beans

$\mathrm{B}_{60}=$ Ratio workers wage for a day / maize price per $\mathrm{kg}$

$\mathrm{B}_{61} \quad=$ Total of working days (staples)

$\mathrm{B}_{62}=$ Working days paid with maize/total working days

$\mathrm{B}_{63}=$ Ratio workers' wage for a day / bean price per $\mathrm{kg}$

$\mathrm{B}_{64}=$ Accrescence Coffee forest

$\mathrm{B}_{65}=$ Accrescence natural forest

$\mathrm{B}_{66}=$ Ratio maize/fertilizer price

e) Nitrogen concentrations

$$
\begin{aligned}
\mathrm{c}_{\mathrm{M}} & =\text { Maize } \\
\mathrm{c}_{\mathrm{B}} & =\text { Beans } \\
\mathrm{c}_{\mathrm{GM}} & =\text { Plant material maize } \\
\mathrm{c}_{\mathrm{GB}} & =\text { Plant material beans } \\
\mathrm{c}_{\mathrm{DM}} & =\text { Fertilizer maize } \\
\mathrm{c}_{\mathrm{DB}} & =\text { Fertilizer beans } \\
\mathrm{c}_{\mathrm{Ei}} & =\text { Egg } \\
\mathrm{c}_{\mathrm{H}} & =\text { Chicken } \\
\mathrm{c}_{\mathrm{L}} & =\text { Milk } \\
\mathrm{c}_{\mathrm{P}} & =\text { Pig } \\
\mathrm{c}_{\mathrm{K}} & =\text { Cow } \\
\mathrm{c}_{\mathrm{E}} & =\text { Horses and Mules } \\
\mathrm{c}_{\mathrm{F}} & =\text { Human feces } \\
\mathrm{c}_{\mathrm{Pas}} & =\text { Pasture } \\
\mathrm{c}_{\mathrm{MP}} & =\text { Manure pigs } \\
\mathrm{c}_{\mathrm{MH}} & =\text { Manure chicken } \\
\mathrm{c}_{\mathrm{HW}} & =\text { Human waste } \\
\mathrm{c}_{\mathrm{FW}} & =\text { Firewood }
\end{aligned}
$$




$$
\begin{aligned}
& \mathrm{c}_{\mathrm{C}}=\text { Coffee } \\
& \mathrm{c}_{\mathrm{Pu}}=\text { Coffee husk } \\
& \mathrm{c}_{\mathrm{DC}}=\text { Fertilizer coffee } \\
& \mathrm{c}_{\mathrm{R}}=\text { Rice } \\
& \mathrm{c}_{\mathrm{S}}=\text { Sugar }
\end{aligned}
$$

\section{EQUATIONS}

\section{$\underline{\text { Staples }}$}

(1) $A_{14}=365 I\left(B_{5} c_{M}+B_{6} c_{B}\right)$

(2) $A_{15}=F_{M} c_{M}\left(B_{1}-B_{3}\right)+F_{B} c_{B}\left(B_{2}-B_{4}\right)-A_{14}-A_{12}$

IF $A_{15}>F_{M} B_{1} B_{54} B_{55}+F_{B} B_{2} B_{56} B_{57}+B_{58} B_{59} B_{60}+B_{56} B_{61}\left(1-B_{60}\right)$

ELSE

$A_{54}=I\left(B_{50} B_{51} c_{R}+B_{52} B_{53} c_{s}\right)+\left[\left\{F_{M} B_{1} B_{54} B_{55}+F_{B} B_{2} B_{56} B_{57}+B_{58} B_{59} B_{60}+B_{56} B_{61}\left(1-B_{60}\right)\right\}-A_{15}\right]$

(3) $A_{16}=B_{7}\left(B_{1} F_{M} B_{8} c_{G M}+B_{2} F_{B} B_{9} c_{G B}\right)+B_{12}\left(B_{10} F_{M} c_{D M}+B_{11} F_{B} c_{D B}\right)$

(4) $A_{51}=B_{10} F_{M} c_{D M}+B_{11} F_{B} c_{D B}$

(5) $A_{61}=B_{13}\left(\frac{F_{M}+F_{B}+F_{F}}{2}\right)+B_{14} F_{B}$

\section{$\underline{\text { Animals and Pasture }}$}

(6) $A_{12}=c_{M}\left(H B_{15} B_{16}+P B_{17} B_{18}\right)$

(7) $A_{24}=H_{L} B_{23} c_{E i}\left(B_{19}-B_{20} B_{21} B_{22}\right)+H_{L} B_{20} B_{21} B_{24} B_{25} c_{H}+K_{L} K B_{26} B_{27} B_{28} B_{29} c_{L}$

(8)

$$
\begin{aligned}
& A_{25}=H_{S} B_{24} c_{H}+c_{P}\left(L_{S} B_{30}+P_{S} B_{31}\right)+c_{K}\left(V_{s} B_{32}+K_{s} B_{33}\right)+E_{s} B_{34} c_{E}+K_{L} K B_{26} B_{27} B_{28} c_{L}\left(1-B_{29}\right) \\
& \text { (9) } A_{26}=B_{35} B_{36} B_{37} c_{F}\left(1-B_{38}\right)\left(K+E B_{39}\right)+B_{40} B_{41} B_{7} c_{\text {Pas }}
\end{aligned}
$$


(10) $A_{27}=P B_{42} c_{M P}+H B_{43} c_{M H}$

(11) $A_{42}=B_{44} c_{H W}+K B_{26} B_{27} B_{28} B_{45} c_{L}$

(12) $A_{52}=H_{P} B_{24} c_{H}+c_{P}\left(L_{P} B_{30}+P_{P} B_{31}\right)+c_{K}\left(V_{P} B_{32}+K_{P} B_{33}\right)+E_{P} B_{34} c_{E}$

(13) $A_{62}=F_{p} B_{13}$

\section{$\underline{\text { Coffee and Forest }}$}

(14) $A_{34}=B_{46} B_{47} c_{F W}$

(15) $A_{35}=B_{48} F_{C} c_{c}$

(16) $A_{37}=B_{48} B_{49} F_{C} c_{P u}$

(17) $A_{53}=B_{50} F_{C} c_{D C}$

(18) $A_{63}=B_{13}\left(F_{C}+F_{W}\right)$

Famer's Family

(19) $A_{46}=B_{7}\left(A_{34}+A_{74}\right)$

(20) $A_{47}=I B_{51}+\left(B_{7}-1\right)\left(A_{34}+A_{74}\right)$

(21) $A_{54}=I\left(B_{52} B_{53} c_{R}+B_{54} B_{55} c_{s}\right)$

(22) $A_{74}=\left(1-B_{46}\right) B_{47} c_{F W}$

\section{$\underline{\text { Stocks }}$}

(23) $G_{1}(t)=G_{1}(0)+\dot{G}_{1}(t)$

(24) $G_{2}(t)=G_{2}(0)+\dot{G}_{2}(t)$ 
(25) $G_{3}(t)=G_{3}(0)+\dot{G}_{3}(t)$

(26) $G_{4}(t)=G_{4}(0)+\dot{G}_{4}(t)$

\section{$\underline{\text { Change of stocks }}$}

(27) $\dot{G}_{1}=A_{51}+A_{61}-A_{12}-A_{14}-A_{15}-A_{16}$

(28) $\dot{G}_{2}=A_{12}+A_{42}+A_{52}+A_{62}-A_{24}-A_{25}-A_{26}-A_{27}$

(29) $\dot{G}_{3}=A_{53}+A_{63}-A_{34}-A_{35}-A_{37}$

(30) $\dot{G}_{4}=A_{54}+A_{74}-A_{46}-A_{47}$

Additional Equation:

Total_Harvest $=F_{M} c_{M}\left(B_{1}-B_{3}\right)+F_{B} c_{B}\left(B_{2}-B_{4}\right)=A_{14}+A_{15}+A_{12}$

\section{$\underline{\text { 2. Assessment Criteria }}$}

a) N-mining whole farm

$$
\begin{aligned}
& M=\dot{G}_{1}+\dot{G}_{2}+\dot{G}_{3} \\
& \dot{M}=A_{51}+A_{61}-A_{14}-A_{15}-A_{16}+A_{42}+A_{52}+A_{62}-A_{24}-A_{25}-A_{26}-A_{27}+A_{53}+A_{63}-A_{34}-A_{35}-A_{37}
\end{aligned}
$$

b) Degree of self-sufficiency for maize

$$
D S S_{M}=\frac{F_{M} B_{1}}{365 I B_{5}+H B_{15} B_{16}+P B_{17} B_{18}+F_{M}\left(B_{3}+B_{10} B_{66}+B_{56} B_{57}\right)+B_{60} B_{61} B_{62}}
$$

c) Degree of self-sufficiency for beans

$$
D S S_{B}=\frac{F_{B} B_{2}}{365 I B_{6}+F_{B}\left(B_{4}+B_{58} B_{59}\right)+B_{61} B_{63}\left(1-B_{62}\right)}
$$

d) Degree of self-sufficiency for energy

$$
D S S_{E}=\frac{F_{C} B_{64}+F_{W} B_{65}}{B_{47}}
$$




\section{Appendix B: Data, Calculations and Assumptions for the quasi-stationary Model}

\section{a) POPULATION OF THE STATUS QUO}

The population figures were provided by ${ }^{1)}$. They were rounded to 500 families, whereby a family was considered to be the nucleus eating together and having their own household budget. In this study, children from 1-16 years are counted as an average of 0.75 adults on the bases of calorie consumption ${ }^{2)}$. This gives an average of around 6 persons per family.

1): Leemann, E., personal communication.

${ }^{2)}$ : http://www.praxisnetz-hamburg.de/kalorienbedarf htm

\section{b) LAND USE OF THE STATUS QUO}

For calculating the land use and the mass fluxes, the category "varied" was excluded because of the following reasons:

1) Very small area

2) Many different crops

3) Lacking information about these crops

The land used for varied crops was distributed proportionally to the remaining categories on stratum level.

\section{c) MASS FLUXES AND NITROGEN FLUXES FOR THE QUASI-STATIONARY MODEL}

\section{Process Food Production}

IN

\section{Seeds}

The seeds were calculated according to the information from the interviews (see appendix A). They were directly subtracted from the harvest and ,stored on the fields ${ }^{\text {“l }}$ for the following season.

\section{Nitrogen Deposition}

Nitrogen deposition can be calculated after ${ }^{1)}$ according to the precipitation. For the precipitation in San Dionisio of about $1100-1600 \mathrm{~mm} / \mathrm{a}$, a nitrogen deposition of $5 \mathrm{~kg} / \mathrm{ha}$ *a was thus assumed. Due to crop burning and the subsequent nitrogen output to the atmosphere the nitrogen deposition is probably somewhat higher. Nevertheless, as it is difficult to estimate the exact figure, a nitrogen deposition of $5 \mathrm{~kg} / \mathrm{ha} * \mathrm{a}$ was assumed. This was then converted according to its chemical formula $\mathrm{NH}_{3}$ to a mass flux.

1): Stoorvogel et al., 1993: Calculating soil nutrient balances in Africa at different scales. I. Supra- national scale. Fertilizer Research, 35, pp. 227-235.

\section{Nitrogen Fixation}

In the study area the most popular bean cultivar is DOR 364. For this cultivar nitrogen fixation was assessed in a broad study ${ }^{1)}$ and was found to be about $30 \mathrm{~kg} \mathrm{~N}_{2} /$ ha in a low input Guatemalan management system. Of these, only about $40 \%$, thus $12 \mathrm{~kg} \mathrm{~N}_{2} /$ ha, are derived from atmosphere. Although this is quite low in comparison to other figures for common bean which may lie as high as $70 \mathrm{~kg} \mathrm{~N}_{2} \mathrm{~kg} / \mathrm{ha}^{\mathrm{lb}}$ ) or other legumes ${ }^{2)}$, it was used for this model for the following reasons:

a) No fertilizer is used for the beans. This causes on a long-term shortage of phosphorus, which inhibits nodulation.

b) Beans were not inoculated with potent bacterial strains ${ }^{3)}$

c) It was the only study available for DOR 364

d) In the study ${ }^{1)}$ the nitrogen fixation under Central American low input management was assessed.

1): Harardson, G. et al., 1993: Genotypic variation in biological nitrogen fixation by common bean. Plant and Soil, 152, pp. 59-70.

\footnotetext{
${ }^{1}$ In the figurative sense, as there is no storage process.
} 
${ }^{1 b)}$ : In the same study nitrogen fixation derived from the atmosphere was found to be $92-125 \mathrm{~kg} \mathrm{~N}_{2} /$ ha for various bean lines in summer.

2): In Giller and Wilson, 1991, Nitrogen Fixation in Tropical Cropping Systems. CABI, Wallingford, Oxon, UK $\mathrm{N}_{2}$-fixation was found to be e.g. 100-152 $\mathrm{kg} \mathrm{N}_{2} /$ ha for Arachis hypogaea (peanut) in India, whereof 86-92 \% (86-140 $\mathrm{kg} \mathrm{N}$ ) are derived from the atmosphere.

3): Döbenreiner, J., 1997: biological nitrogen fixation in the tropics: social and economic contributions. Soil Biol. Biochem., 29 (5/6), pp. 771-774, cites Hungria and Neves, 1988: Selection of more efficient and competitive Rhizobium strains and bean genotypes could increase annual yields to $1500 \mathrm{~kg} / \mathrm{ha}$ with $4 \% \mathrm{~N}$ equivalent to 375 millions US\$.

\section{Fertilizer}

Fertilizer needs were assessed in the interviews with the farmers (see appendix A). For the model it was assumed that they only used Urea, e.g. the 15-15-15 formula fertilizer, which was used much less by the farmers, was converted into $\mathrm{N}$ units and then into $\mathrm{kg}$ of Urea.

\section{OUT}

\section{Auto consumption}

Auto consumption was assessed in the interviews. Nevertheless, as figures varied considerably, and as some of them were obviously wrong, they were compared with figures from FAO ${ }^{1)}$. Although those were not representative for the rural Nicaraguan population (e.g. much lower maize and higher rice consumption), they helped to estimate consumption. It also allowed comparison with other developing countries. Thus, in e.g. Thailand very high cereal consumption was observed. This coincides with our own figures for maize and rice consumption in the study region. Furthermore, in ${ }^{2)}$ a figure of $28 \mathrm{qq}$ $(1270 \mathrm{~kg})$ of maize is mentioned as auto consumption for a farm family of 8 members in Honduras. If we assume that about 7 hens are kept, we reach this figure $(1190 \mathrm{~kg}$, or $1340 \mathrm{~kg}$ if additionally a pig is kept) with our consumption figures used in this study.

1):FAOSTAT, 2001/02. http://www.fao.org/waicent/portal/statistics_en.asp

2): FAO, 2001: Sequía y Producción de Granos Básicos en Centro América. http://www.rlc fao.org/prior/recnat/pdf/granos.pdf

\section{Waste gases}

a) Fertilizer losses

Fertilizer losses were calculated as a percentage of total fertilizer $\mathrm{N}$ input. $\mathrm{N}$ losses through volatilization range from $0-50 \%$ of the $\mathrm{N}$ applied ${ }^{1)}$. For urea, volatilization losses are especially high. They can exceed $50 \%$ of the $\mathrm{N}$ applied ${ }^{2)}$ according to climatic characteristics and way of application. For the model all the fertilizer was assumed to be urea (see fertilizer).A loss to the atmosphere of $35 \% \mathrm{~N}$ was assumed, as the climate when fertilizers are applied is humid and warm. The actual losses may lie even higher as fertilizers are applied superficially and thus exposed to climatic impact.

b) Burning of plant residues

For the assessment of the waste gases produced by the burning of plant residues, the amount of these had to be calculated first. For maize, according to ${ }^{3)}$, the dry weight harvest to plant ratio is $42: 58$. For beans, the ratio is $1.2^{4)}$. In the study region it happens quite often that the plant develops, but the harvest is lost due to snails, droughts or long lasting rains. Therefore, and as the harvest figures are assumed to have a big error margin, the small amount of water the harvest contains was neglected for the calculation of the plant residue production. It was assumed that roughly all nitrogen is transferred to the waste gases $(\mathrm{k}=1)$.

1): Freney, J.R. and Black, A.S., 1988: Importance of ammonia volatilization as a loss process. In: Wilson, J.R., Advances in Nitrogen Cycling in Agricultural Ecosystems. Proceedings of the Symposium on Advances in Nitrogen Cycling in Agricultural Ecosystems held in Brisbane, Australia, 11-15 $5^{\text {th }}$ May 1987. CABI, Wallington, Oxon, UK.

2). Bremner, J.M., 1995: Recent research on problems in the use of urea as a nitrogen fertilizer. Fertilizer Research, 42 , pp. 321-329.

3): FAO (ed.), 1993: Maize in human nutrition. FAO, Rome, Italy.

4): Smil, V. 1981: Of trees and straws, Energy and the developing nations, Auer, P. (ed.)), Pergamon Policy Studies, Pergamon Press, New York, as cited in Stout, B.A., Handbook of Energy for World Agriculture, p. 209, Elsevier Applied Science, 1990. 


\section{Harvest sold}

Although this figure was a question in the interviews, it finally had to be assessed with the formula

Harvest sold $=$ total harvest - seeds - auto consumption - fodder

Maize was assumed to have a water content of $14 \%^{1)^{2)}}$ when stored, beans $8 \%{ }^{2)}$.

1): Orozco, P.P., personal communication; Boltshauser et al., 1993: Fütterungsempfehlungen und Nährwerttabellen für Schweine. Landwirtschaftliche Lehrmittelzentrale, Zollikofen.

${ }^{2)}$ : www rlc.fao.org/bases/alimentos; A323, B 518: Frijol.

\section{Fodder}

a) Fowls

In the interviews the fodder given to the birds was assessed. Again this was a difficult question for the farmers. They feed the chicken with a handful of maize every here and then. The figures were thus compared with figures from Switzerland ${ }^{1)}$ and the available information was combined to an estimate of a maximum daily ration of $120 \mathrm{~g}$ per hen and day. Thus the fodder needs in the model are quite high. Thus, for landless farmers the rations were calculated to be $80 \mathrm{~g}$ per hen and day, which was also stated by the landless in the interviews.

b) Pigs

Pigs are fattened mainly in the last two months of their lives. Before they get the household waste and after a certain age some maize. In the households where there is whey, they are also given that. It was assumed that pigs ate $2.5 \mathrm{~kg}$ of maize a day during the fattening period. Before this, their maize consumption was neglected.

1): www.progetto-poschiavo.ch/e-vado/ev3/progetti/siti/barbara/Ernaehrung.htm and www.bio4you.ch/fakten/gefluegelhaltung htm

\section{Erosion/Leaching}

Erosion and leaching was neglected for the following reasons:

- As no erosion or leaching data was available

- the management of the farms was the goal of the analysis

- The management had to be comparable.

It can nevertheless be assumed that erosion is moderate to severe. On one hand, this supposition bases on the statements of local soil specialists ${ }^{1)}$ and various publications ${ }^{2)}{ }^{3)}$. On the other hand, farmers confirmed the severity of erosion in the interviews ${ }^{4)}$.

1): Rodríguez Ibarra, I., personal communication

2): Alfsen, K. H., et al., 1996: The Cost of Soil Erosion in Nicaragua. Ecological Economics, 16, pp. 129-145.

3): Veihe, A., et al., 2001: Modelling of event-based soil erosion in Costa Rica, Nicaragua and Mexico: evaluation of the EUROSEM model. Catena, 44, pp. 187-203.

4) e.g. Molinares, J.F., 26.11.00.

\section{Harvest losses}

Considerable post harvest losses of $9-14 \%$ of stored maize have been reported from Central America ${ }^{1)}$. Nevertheless, harvest figures from the interviews in this study are not very precise. The farmers estimate their harvest by the volume. Furthermore, bad maize is fed to the fowls and pigs and hence used. Harvest and post harvest losses have thus been neglected.

1): Raboud, G., Narvaez, M., Sieber, J., 1984: Evaluación de las pérdidas post-producción de maíz a nivel de pequeños y medianos productores en Honduras (América Central). Cooperación Suiza al Desarrollo (COSUDE), Tegucigalpa, Honduras.

\section{Ash}

The ash was estimated to weigh about $1 \%$ of the burnt plant material. 


\section{Process Animal Production}

\section{GENERAL}

\section{Production of Pasture}

Pasture production in the study region is about between 11-14t dry matter/ha*a, depending on the year and the pasture type

${ }^{1)}$. It was assumed that local pastures produce an average of $12.5 \mathrm{t} / \mathrm{ha} * \mathrm{a}$.

1): Schmidt, A., personal communication.

\section{Reproduction of animals}

1) Chicken

Chicken do not reproduce freely; how many chickens are born is steered by the hens owners (eggs are taken away and eaten if chicken are not wanted). Thus, it had to be estimated and assessed through interviews with key persons, which stratum allowed how many chicken to hatch.

Landless: One laying hen is given ten fertilized eggs a year by a provider. Five chicken have to be given back to the egg provider.

Small: Three laying hens, of which one hatches about 10 chicken a year.

Medium: Seven laying hens, of which five hatch about 10 chicken a year.

Big: Has about seven laying hens, of which five hatch 10 chicken once a year.

2) Pigs

As there are only few farmers breeding pigs, it was assumed that all the piglets are imported from outside the region.

3) Cows

According to ${ }^{1)}$ in the Central Highlands about $50 \%$ of the cows have offspring each year. This was confirmed by the farmers in the study region.

1): Nitlapán-UCA, 1995: Diagnóstico de la producción agropecuaria en el interior del país. Análisis de encuesta Rural 1995.

IN

\section{Nitrogen Deposition \\ See food production.}

\section{Nitrogen Fixation}

As except for a few trials no leguminous fodder crops are grown, nitrogen fixation on pastures has been neglected.

\section{Fodder}

See food production.

\section{Animals bought}

The animals on the farm and in the region were assumed to be in a dynamic equilibrium. Chicken and cows are bred on the farms, while most farmers in Susulí only grown pigs. Many of them are bought from neighboring communities. It was assumed that they were bought at about 2 months of age and weighed about $8.6 \mathrm{~kg}^{1}$.

${ }^{1)}$ : Interviews with local key persons.

\section{Household waste}

Dry household waste was estimated by ${ }^{1)}$ to amount to about $100 \mathrm{~kg} /$ family*a for a rural family in Africa. This figure was taken as a basis for the model. Nevertheless, only families of medium and big farmers were assumed to create waste, while for small and landless farms the waste was neglected. Of course these farms also create waste, but much less, as not severely spoilt food is eaten in periods of crisis. 
As owners of cows the big farmers additionally produces whey through the production of soft cheese (cuajada). The whey is fed to the pigs, which are assumed to be of a bigger, heavier race than the pigs of the other strata. Of 101 of milk, about 1 $\mathrm{kg}$ of cheese is produced ${ }^{2}$. The remaining 91 of whey contain $0.7-0.8 \%$ of protein ${ }^{3)}$.

1): Wortmann, C.S. and Kaizzi, C.K., 1998: Nutrient Balances and Expected Effects of Alternative Practices in Farming Systems of Uganda. Agriculture, Ecosystems and Environment, 71, pp. 115-129.

2) :"Cheese". The Columbia Encyclopedia, Sixth Edition Copyright $(\mathrm{C}$ 2000, Columbia University Press.

3): Boltshauser et al., 1993: Fütterungsempfehlungen und Nährwerttabellen für Schweine. Landwirtschaftliche

Lehrmittelzentrale, Zollikofen.

OUT

\section{Waste gases}

a) Animals

Waste gases containing $\mathrm{N}$ are produced from the urine and feces of all the animals. Yet, for pigs and fowls all the manure is lost to the production system (see manure). Nevertheless, the urine and feces of the horses and cows are dropped on the pastures and thus part of the nitrogen is reintegrated into the soil. The part lost to the atmosphere is calculated as follows for cows:

Protein content of local pasture ${ }^{1)}$ : $1.28-2 \%$

Fodder consumption local cows ${ }^{2)}$ : $\quad 10 \mathrm{~kg} \mathrm{TS} / \mathrm{d}$

Excretion of $\mathrm{N}^{2)}$ : $\quad 70-80 \%$

Ammonia Volatilization for this specific case ${ }^{3)}: \quad 8-13 \%$

For cows, calculated with average numbers, results an $\mathrm{N}$ loss of $5 \mathrm{~kg} / \mathrm{cow}^{*}$ a to the atmosphere.

For horses, the same fodder consumption has been assumed. According to ${ }^{4)} 38 \%$ of the excretion is liquid, whereof according to ${ }^{3)}$ an average of $11 \%$ of the $\mathrm{N}$ is lost to the atmosphere.

1): Schmidt, A., personal communication.

2): Kreuzer, M., personal communication.

3): Oenema, O., personal communication. Similar figures (10\%) were assumed by Wortmann, C.S. and Kaizzi, C.K., 1998; Nutrient balances and expected effects of alternative practices in farming systems of Uganda. Agriculture, Ecosystems and Environment, 71, pp. 115-129.

4): Gotaas, H.B., 1956: Composting. Sanitary Disposal and Reclamation of Organic Wastes. World Health Organization, Geneva.

b) Burning of pastures

For the calculation of emissions it was assumed that an average of $12.5 \mathrm{t} / \mathrm{ha} * \mathrm{a}$ of pasture grows in 5 growth periods. Thus, for each growth period about $2500 \mathrm{~kg}$ dry substance are produced, of which at least half is consumed by the cows. This means that on each 1 ha pasture plot about $1250 \mathrm{~kg}$ pasture with an average of $1.6 \% \mathrm{~N}$ is burnt, which corresponds to $20 \mathrm{~kg}$ $\mathrm{N} /$ ha lost to the atmosphere.

1): Schmidt, A., personal communication.

\section{Manure}

For pigs dry matter manure production of $55 \mathrm{~kg}$ per pig and year was assumed. For chicken the figure amounts to $11 \mathrm{~kg}$ per hen and year $\left.{ }^{1) 2} 3\right)$.

1): According to own assumptions based on the nitrogen balance of animals.

2): Kreuzer, M. and Machmüller, A., 2002: Tierernährung und Ökologie. Ing.-Agr. 8. Semester, D-AGRL, ETHZ.

${ }^{3)}$ : Brandjes, P.J., et al., 1996: Environmental Impact of Animal Manure Management. FAO, Rome. 
Animals and animal products sold

Animals sold contain pigs, calves and cows. Pigs are usually raised as a living savings account or in order to celebrate important events. In the model it was assumed that all the pigs were sold weighing $60 \mathrm{~kg}-$ and $90 \mathrm{~kg}$ in the case of the big farmer (so-called improved race). As for the cows, in order to maintain the dynamic equilibrium all the male calves were sold ( $1 / 2$ of the offspring) and the female calves replaced an aging cow. The adult cows and horses are assumed to weigh $350 \mathrm{~kg}$, the calf $150 \mathrm{~kg}^{1) 2}$.

1): Statement of local key persons

2): Own estimations.

\begin{abstract}
Animal products
a) Eggs

It was assumed that a laying hen produced one egg every second day. Most farmers claimed that it was such, even though other key persons estimated that it was less. All the eggs produced are consumed on the farm. For every brood the hen is assumed to produce about 40 eggs less than a hen laying eggs all year round.
\end{abstract}

b) Meat for auto consumption

Meat was assumed to be chicken meat only. As the animals are in a dynamic equilibrium all the chicken born in a year were consumed when they weighed about $1.2 \mathrm{~kg} /$ animal. $(0.9 \mathrm{~kg} \text { of meat })^{12)}$. All the chicken are consumed on the farm.

1): Local key persons.

2: Own assumptions.

c) Milk

According to the interviews and ${ }^{1)}$, cows in this zone of Nicaragua give an average of about 41 of milk a day during the period when fodder is sufficient in quality and quantity. This was assumed to last about 7 months $(\approx 210$ days $)$ a year. Thus, each cow with a calf (about $50 \%$ of adult cows) gives about 840 lts of milk a year. Of these, it was assumed, the farmer's family consumes half in form of cheese. The rest is sold in form of milk.

1): Nitlapán-UCA, 1995: Diagnóstico de la producción agropecuaria en el interior del país. Análisis de Encuesta Rural 1995. Universidad Centroamericana, Managua, Nicaragua.

Erosion/Leaching

(see same chapter in food production)

\title{
Process Coffee and forest
}

\section{GENERAL}

\section{Wood production and forest density}

In ${ }^{1)}$ the specific wood reserve for coffee plantations is estimated to be $50 \mathrm{~m}^{3} /$ ha. The average yearly accrescence for coffee plantations is estimated to be $15 \mathrm{~m}^{3} /$ ha. If we assume a wood density of about $0.6 \mathrm{t} / \mathrm{m}^{3}$, this corresponds to about $9 \mathrm{t} / \mathrm{ha}$ a a For the accrescence of natural forest an average of $20 \mathrm{~m}^{3} / \mathrm{ha}^{*} \mathrm{y}$ was assumed.

1) Rivas, S., 2001: Ein agro-ökologisches regionalisiertes Modell zur Analyse des Brennholzversorgungssystems in Entwicklungsländern. Fakultät Energietechnik der Universität Stuttgart, University of Stuttgart, Germany.

IN

\section{Nitrogen Deposition}

(see same chapter in food production)

\section{Nitrogen Fixation}

The nitrogen fixed by some forest trees as mentioned in ${ }^{1)}$ was neglected. 
1): Kass, D.C.L. et al., 1997: The role of nitrogen fixation and nutrient supply in some agro forestry systems of the Americas. Soil Biol. Biochem., 29 (5/6), pp. 775-785.

\section{Fertilizer}

Fertilizer is currently not used on coffee plots due to the low coffee price on the world market.

OUT

\section{Coffee auto consumption}

As harvest figures are approximate and coffee auto consumption minute in comparison to the total production (about $2 \%$ of a bad harvest of a 1 ha plot), it was neglected.

\section{Coffee sold}

As coffee auto consumption is neglected, the coffee sold is equal to the total coffee harvest.

\section{Coffee Husk}

According to ${ }^{1)}$, the weight of coffee husk is about $53 \%$ of the coffee harvest weight.

1) Wrigley, G., 1988: Coffee. Longman Scientific \& Technical, Essex, UK.

\section{Firewood}

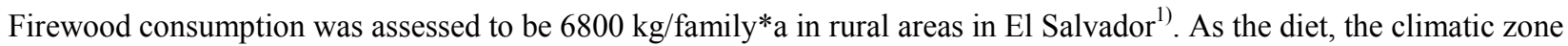
and the cooking facilities are similar, the same firewood consumption has been assumed for the study region.

1) Rivas, S., 2001: Ein agro-ökologisches regionalisiertes Modell zur Analyse des Brennholzversorgungssystems in Entwicklungsländern. Fakultät Energietechnik der Universität Stuttgart, University of Stuttgart, Germany.

\section{Process Farmer's family}

IN

\section{Auto consumption}

(see food production)

\section{Food bought}

According to the interviews and the figures from $\mathrm{FAO}^{1)}$ the sugar and rice consumption per person and day lies close to 100 $\mathrm{g} /$ cap* $^{\mathrm{d}}$. Of course this is only the case, if there is the means to buy these items.

(MEAT)

1) FAOSTAT; http://apps fao.org/page/collections?subset=agriculture

\section{Firewood}

(see coffee and forest)

\section{Household Waste}

(see animal production)

\section{OUT}

\section{Waste}

The Waste flux is composed of human excrements and ash, although the latter does hardly contribute nitrogen. This is the reason why it is neglected in the nitrogen flow.

The quantity of feces and urine per capita and day was calculated after ${ }^{1)}$. It was assumed to be $19 \mathrm{~kg}$ dry weight of feces and $22 \mathrm{~kg}$ dry weight of urine per person and year. 
1): Gotaas, H.B., 1956: Composting. Sanitary Disposal and Reclamation of Organic Wastes. World Health Organization, Geneva, Switzerland.

\section{Waste gases}

The waste gases out of the process farmer's household derive from the burning of firewood (see firewood). It is assumed that roughly all nitrogen is transferred to the atmosphere $(\mathrm{k}=1)$.

\section{Stocks for the processes food production, animal production and coffee \& forest}

Nitrogen stocks of soils were estimated to be $3000 \mathrm{~kg} / \mathrm{ha}^{1)}$.

1): Pagel, H. et al., 1982: Pflanzennährstoffe in tropischen Böden - ihre Bestimmung und Bewertung. Deutscher Landwirtschaftsverlag Berlin, DDR.

\section{d) LAND USE IN SCENARIO 1}

\begin{tabular}{lllll}
\hline \multirow{2}{*}{ Land Use [ha] } & Landless & Small1 & Small2 & Medium \\
\cline { 2 - 5 } & $\begin{array}{l}\text { Landless in Status } \\
\text { Quo }\end{array}$ & $\begin{array}{l}\text { Small in Status } \\
\text { Quo }\end{array}$ & $\begin{array}{l}\text { Medium in Status } \\
\text { Quo }\end{array}$ & Big in Status Quo \\
\hline Land Tenure & 0 & 0.94 & 2.75 & 9.42 \\
\hline Staples & 0 & 0.94 & 2.42 & 4.2 \\
\hline Fallow & 0 & 0 & 0 & 0.8 \\
\hline Coffee Forest & 0 & 0 & 0.33 & 1.2 \\
\hline Natural Forest & 0 & 0 & 0 & 0.6 \\
\hline Pasture & 0 & 0 & 0 & 3.4 \\
\hline Varied & 0 & 0 & 0 & 0 \\
\hline
\end{tabular}

\section{e) ASSUMPTIONS FOR SCENARIO 2}

If not listed separately, the assumptions of a) are valid.

\section{Meat Consumption}

According to ${ }^{1)}$ yearly per capita meat consumption in Switzerland sums up to $50.8 \mathrm{~kg}$. Thereof, $9 \mathrm{~kg}$ is fowl meat, roughly half is pork, $3 \mathrm{~kg}$ is beef and the rest is composed of a variety of meats. In scenario 2 , all types of meat were assumed to be equivalent. As in the study region only cattle, pigs and chicken are held, the meat consumed by the inhabitants of the region was distributed the following way: $9 \mathrm{~kg}$ was assumed to be chicken meat, $28 \mathrm{~kg}$ veal, and the rest, namely $14 \mathrm{~kg}$ pork. The veal meat is the equivalent of the calves born to the cows covering the milk demand per capita. $60 \%$ of the live weight of calves and pigs is assumed to be meat consumed by the farmers' families.

${ }^{1)}$ : Bundesamt für Landwirtschaft, 2002. www.blw.admin.ch/fakten/statistik/d/tabelle_10.pdf

\section{Stocking rate}


The stocking rate was assumed to be 1.4 adult cows or horses per ha of pasture ${ }^{1)}$.

1): Farmers' and key persons' stating the maximum stocking rate in this region.

\section{f) N-CONCENTRATION OF GOODS}

\begin{tabular}{|c|c|c|c|c|}
\hline Item & $\begin{array}{l}\text { N-Concentration } \\
{[\%]}\end{array}$ & $\begin{array}{l}\text { Water } \\
\text { Content } \\
\end{array}$ & $\begin{array}{l}\text { Energy Content } \\
{[\mathrm{MJ} / \mathrm{kg}]}\end{array}$ & Source \\
\hline Ash & $\approx 0$ & 0 & - & 1 \\
\hline Beans & $3^{1}$ & 8 & 15 & 2 \\
\hline Bean Plant material & 3 & 0 & - & 3 \\
\hline Beef & $3^{1}$ & 70 & 5.5 & ${ }^{2}$ (average) \\
\hline Chicken meat & $3^{1}$ & 70 & 7.2 & ${ }^{2}$ (average) \\
\hline Coffee & 1.5 & 0 & - & 4 \\
\hline Coffee Husk & 1.1 & 0 & - & 4 \\
\hline Cow (living) & 3 & 70 & - & ${ }^{2}$ (average) \\
\hline Eggs & $2^{1}$ & 75 & 6.6 & 2 \\
\hline Feces & 5 & 0 & - & 5 \\
\hline \multicolumn{5}{|l|}{ Fertilizer } \\
\hline Urea & 46 & 0 & - & 3 \\
\hline $15-15-15$ & 15 & 0 & - & 3 \\
\hline Firewood & 0.37 & 0 & 15 & 6 \\
\hline Household Waste & 1.1 & 0 & - & 1 \\
\hline \multicolumn{5}{|l|}{ Manure } \\
\hline Chicken & 3.6 & 0 & - & 7 \\
\hline Pigs & 2.9 & 0 & - & 7 \\
\hline Maize & $1.3^{1}$ & 14 & 15.7 & 2 \\
\hline Maize Plant Material & 0.7 & 0 & - & 8 \\
\hline Milk & $0.55^{1}$ & 88 & 2.6 & 2 \\
\hline Pasture & $1.28-2$ & 0 & - & 9 \\
\hline
\end{tabular}

\footnotetext{
${ }^{2}$ Edible form of food (wet weight)
} 


\begin{tabular}{lllll}
\hline Pork & $3^{1}$ & 70 & 11.3 & 2 \\
\hline Rice & $1.2^{1}$ & 2 & 14.6 & 2 \\
\hline Sugar & $0^{1}$ & 0 & 16.6 & 5 \\
\hline Urine (Human) & 15 & 0 & - & 10 \\
\hline Whey & 0.1 & 94 & - & \\
\hline
\end{tabular}

\footnotetext{
${ }^{1}$ Wortmann, C.S. and Kaizzi, C.K., 1998: Nutrient Balances and Expected Effects of Alternative Practices in Farming Systems of Uganda. Agriculture, Ecosystems and Environment, 71, pp. 115-121.

${ }^{2}$ FAO LATINFOODS. Database: www rlc.fao.org/bases/alimentos.

${ }^{3}$ Yuste Perez, M.P., 1999: Handbook of Agriculture. Idea Books, Barcelona, Spain.

${ }^{4}$ Wrigley, Gordon (1988): Coffee, p.159.

${ }^{5}$ Gotaas, H.B., 1956: Composting. Sanitary Disposal and Reclamation of Organic Wastes. World Health Organization, Geneva, Switzerland.

${ }^{6}$ Müller, D., Öhler, D., Baccini, P., 1995: Regionale Bewirtschaftung von Biomasse. Vdf Hochschulverlag, Zürich, Switzerland.

${ }^{7}$ Own assumption: Nitrogen balance has to equal 0 .

${ }^{8}$ FAO, 1992. Maize in human nutrition. Roma, Italy.

${ }^{9}$ A. Schmidt, personal communication

${ }^{10}$ Boltshauser et al., 1993: Fütterungsempfehlungen und Nährwerttabellen für Schweine. Landwirtschaftliche

Lehrmittelzentrale, Zollikofen.
} 


\section{Appendix C: Parameters Strata}

\begin{tabular}{|c|c|c|c|c|c|c|}
\hline & Unit & Code & Landless & Small & Medium & Big \\
\hline $\begin{array}{l}\text { Family } \\
\text { Members }\end{array}$ & $\begin{array}{l}\text { Persons/ } \\
\text { family }\end{array}$ & I & 6.15 & 5.3 & 6.25 & 6.35 \\
\hline Area Maize & ha/farm & $\mathrm{F}_{\mathrm{M}}$ & 0.27 & 0.82 & 1.84 & 2.23 \\
\hline Area Beans & ha/farm & $\mathrm{F}_{\mathrm{B}}$ & 1.13 & 2.83 & 4.67 & 6.94 \\
\hline Area Fallow & ha/farm & $\mathrm{F}_{\mathrm{F}}$ & 0 & 0 & 0.55 & 1.41 \\
\hline $\begin{array}{l}\text { Area Staples } \\
\text { Total }\end{array}$ & ha/farm & $\mathrm{F}_{\mathrm{S}}$ & 0.7 & 1.83 & 3.53 & \\
\hline Area Pasture & ha/farm & $\mathrm{F}_{\mathrm{P}}$ & 0 & 0 & 1.19 & 9.93 \\
\hline $\begin{array}{l}\text { Area Coffee } \\
\text { Forest }\end{array}$ & ha/farm & $\mathrm{F}_{\mathrm{C}}$ & 0 & 0.25 & 0.63 & 2.77 \\
\hline $\begin{array}{l}\text { Area Natural } \\
\text { Forest }\end{array}$ & ha/farm & $\mathrm{F}_{\mathrm{W}}$ & 0 & 0 & 0.28 & 1.53 \\
\hline $\begin{array}{l}\text { Total number } \\
\text { of chicken }\end{array}$ & $\begin{array}{l}\text { Number of } \\
\text { animals }\end{array}$ & $\mathrm{H}$ & 2.9 & 8.85 & 12.4 & 13.6 \\
\hline $\begin{array}{l}\text { Ratio laying } \\
\text { hens/ total } \\
\text { number of } \\
\text { chicken }\end{array}$ & Ratio & $\mathrm{H}_{\mathrm{L}}$ & 0.43 & 0.37 & 0.56 & 0.55 \\
\hline Chicken sold & $\begin{array}{l}\text { Number of } \\
\text { animals }\end{array}$ & $\mathrm{H}_{\mathrm{S}}$ & $5^{1}$ & 0 & 0 & 0 \\
\hline $\begin{array}{l}\text { Chicken } \\
\text { purchased }\end{array}$ & $\begin{array}{l}\text { Number of } \\
\text { animals }\end{array}$ & $\mathrm{H}_{\mathrm{P}}$ & 0 & 0 & 0 & 0 \\
\hline Pigs & $\begin{array}{l}\text { Number of } \\
\text { animals }\end{array}$ & $\mathrm{P}$ & 0 & 0 & 1 & 2 \\
\hline Pigs sold & $\begin{array}{l}\text { Number of } \\
\text { animals }\end{array}$ & $\mathrm{P}_{\mathrm{S}}$ & 0 & 0 & 1 & 2 \\
\hline Pigs purchased & $\begin{array}{l}\text { Number of } \\
\text { animals }\end{array}$ & $\mathrm{P}_{\mathrm{P}}$ & 0 & 0 & 0 & 0 \\
\hline Piglets sold & $\begin{array}{l}\text { Number of } \\
\text { animals }\end{array}$ & $\mathrm{L}_{\mathrm{S}}$ & 0 & 0 & 0 & 0 \\
\hline $\begin{array}{l}\text { Piglets } \\
\text { purchased }\end{array}$ & $\begin{array}{l}\text { Number of } \\
\text { animals }\end{array}$ & $\mathrm{L}_{\mathrm{P}}$ & 0 & 0 & 1 & 2 \\
\hline Horses & $\begin{array}{l}\text { Number of } \\
\text { animals }\end{array}$ & $\mathrm{E}$ & 0 & 0 & 1 & 2 \\
\hline Horses sold & $\begin{array}{l}\text { Number of } \\
\text { animals }\end{array}$ & $\mathrm{E}_{\mathrm{S}}$ & 0 & 0 & 0 & 0 \\
\hline
\end{tabular}

\footnotetext{
${ }^{1}$ The landless farmer often gets fertilized eggs of an improved race, one of his hens hatches them and he gives half of the offspring to the donator of the eggs.
} 


\begin{tabular}{|c|c|c|c|c|c|c|}
\hline $\begin{array}{l}\text { Horses } \\
\text { purchased }\end{array}$ & $\begin{array}{l}\text { Number of } \\
\text { animals }\end{array}$ & $\mathrm{E}_{\mathrm{P}}$ & 0 & 0 & 0 & 0 \\
\hline $\begin{array}{l}\text { Cows and } \\
\text { calves }\end{array}$ & $\begin{array}{c}\text { Number of } \\
\text { animals }\end{array}$ & $\mathrm{K}$ & 0 & 0 & 0 & 6.7 \\
\hline $\begin{array}{l}\text { Adult cows } \\
\text { (potentially } \\
\text { lactating) }\end{array}$ & $\begin{array}{l}\text { Number of } \\
\text { animals }\end{array}$ & $\mathrm{K}_{\mathrm{L}}$ & 0 & 0 & 0 & 0.6 \\
\hline Cows sold & $\begin{array}{l}\text { Number of } \\
\text { animals }\end{array}$ & $\mathrm{K}_{\mathrm{S}}$ & 0 & 0 & 0 & 1 \\
\hline $\begin{array}{l}\text { Cows } \\
\text { purchased }\end{array}$ & $\begin{array}{l}\text { Number of } \\
\text { animals }\end{array}$ & $\mathrm{K}_{\mathrm{P}}$ & 0 & 0 & 0 & 0 \\
\hline Calves sold & $\begin{array}{c}\text { Number of } \\
\text { animals }\end{array}$ & $\mathrm{V}_{\mathrm{S}}$ & 0 & 0 & 0 & 1 \\
\hline $\begin{array}{l}\text { Calves } \\
\text { purchased }\end{array}$ & $\begin{array}{c}\text { Number of } \\
\text { animals }\end{array}$ & $\mathrm{V}_{\mathrm{P}}$ & 0 & 0 & 0 & 0 \\
\hline Maize harvest & $\mathrm{kg} / \mathrm{ha}$ & $\mathrm{B}_{1}$ & 1688 & 1400 & 2123 & 2292 \\
\hline Bean harvest & $\mathrm{kg} / \mathrm{ha}$ & $\mathrm{B}_{2}$ & 780 & 681 & 857 & 909 \\
\hline Maize seeds & $\mathrm{kg} / \mathrm{ha}$ & $\mathrm{B}_{3}$ & $0^{2}$ & 18 & 21.5 & 21.2 \\
\hline Beans seeds & $\mathrm{kg} / \mathrm{ha}$ & $\mathrm{B}_{4}$ & $0^{2}$ & 54 & 53.2 & 51.9 \\
\hline $\begin{array}{l}\text { Average maize } \\
\text { consumption }\end{array}$ & $\mathrm{kg} /$ cap*d $^{*}$ & $\mathrm{~B}_{5}$ & $0.2^{3}$ & 0.3 & 0.3 & 0.3 \\
\hline $\begin{array}{l}\text { Average bean } \\
\text { consumption }\end{array}$ & $\mathrm{kg} /$ cap*d & $\mathrm{B}_{6}$ & $0.15^{3}$ & 0.2 & 0.2 & 0.2 \\
\hline $\begin{array}{l}\text { Transfer } \\
\text { coefficient for } \mathbf{N} \\
\text { in a burning } \\
\text { process }\end{array}$ & $\begin{array}{l}\text { Ratio } \mathrm{N} \text { to the } \\
\text { atmosphere/ } \\
\text { total } \mathrm{N} \text { content }\end{array}$ & $\mathrm{B}_{7}$ & 1 & 1 & 1 & 1 \\
\hline $\begin{array}{l}\text { Plant material } \\
\text { maize }\end{array}$ & $\begin{array}{l}\text { Ratio harvest } \\
\text { maize } \\
\text { (grains)/ plant } \\
\text { material }\end{array}$ & $\mathrm{B}_{8}$ & 1.38 & 1.38 & 1.38 & 1.38 \\
\hline $\begin{array}{l}\text { Plant material } \\
\text { beans }\end{array}$ & $\begin{array}{c}\text { Ratio harvest } \\
\text { beans/ plant } \\
\text { material }\end{array}$ & $\mathrm{B}_{9}$ & 1.2 & 1.2 & 1.2 & 1.2 \\
\hline $\begin{array}{l}\text { Fertilizer } \\
\text { application } \\
\text { maize }\end{array}$ & $\mathrm{kg} / \mathrm{ha}$ & $\mathrm{B}_{10}$ & 160 & 129 & 155 & 170 \\
\hline $\begin{array}{l}\text { Fertilizer } \\
\text { application } \\
\text { beans }\end{array}$ & $\mathrm{kg} / \mathrm{ha}$ & $\mathrm{B}_{11}$ & 0 & 0 & 0 & 0 \\
\hline
\end{tabular}

\footnotetext{
${ }^{2}$ Is paid by the landlord for sharecropped land. Rest has been neglected.

${ }^{3}$ Landless farmers usually have periods of hardship and hunger. Thus it is assumed that on an average they consume less food than the others.
} 


\begin{tabular}{|c|c|c|c|c|c|c|}
\hline $\begin{array}{l}\text { Fertilizer loss } \\
\text { by } \\
\text { volatilization }\end{array}$ & $\begin{array}{c}\text { Ratio N } \\
\text { volatilized/ } \\
\text { N applied }\end{array}$ & $\mathrm{B}_{12}$ & 0.35 & 0.35 & 0.35 & 0.35 \\
\hline $\begin{array}{l}\text { Nitrogen } \\
\text { deposition }\end{array}$ & $\mathrm{kg} / \mathrm{ha} * \mathrm{a}$ & $\mathrm{B}_{13}$ & 5 & 5 & 5 & 5 \\
\hline $\begin{array}{l}\text { Nitrogen } \\
\text { fixation }\end{array}$ & $\mathrm{kg} / \mathrm{ha}$ & $\mathrm{B}_{14}$ & 24 & 24 & 24 & 24 \\
\hline Chicken fodder & $\mathrm{kg} /$ cap*d & $\mathrm{B}_{15}$ & 0.06 & 0.12 & 0.12 & 0.12 \\
\hline $\begin{array}{l}\text { Days of feeding } \\
\text { chicken }\end{array}$ & $\mathrm{d} / \mathrm{a}$ & $\mathrm{B}_{16}$ & 365 & 365 & 365 & 365 \\
\hline Pig fodder & $\mathrm{kg} /$ cap*d & $\mathrm{B}_{17}$ & - & - & 2.5 & 2.5 \\
\hline $\begin{array}{l}\text { Days of pigs' } \\
\text { mast }\end{array}$ & $\mathrm{d} / \mathrm{a}$ & $\mathrm{B}_{18}$ & - & - & 60 & 60 \\
\hline $\begin{array}{l}\text { Average } \\
\text { number of eggs } \\
\text { per hen and } \\
\text { year }\end{array}$ & units & $\mathrm{B}_{19}$ & $75^{4}$ & 150 & 150 & 150 \\
\hline $\begin{array}{l}\text { Number of } \\
\text { broods per } \\
\text { brooding } \\
\text { hen/year }\end{array}$ & $\begin{array}{l}\text { broods per } \\
\text { brooding } \\
\text { hen } / \mathrm{a}\end{array}$ & $\mathrm{B}_{20}$ & 1 & 1 & 2 & 2 \\
\hline $\begin{array}{l}\text { Ratio brooding } \\
\text { hens/ total hens }\end{array}$ & Ratio & $\mathrm{B}_{21}$ & 1 & 0.305 & 0.36 & 0.33 \\
\hline $\begin{array}{l}\text { Eggs not laid } \\
\text { because of } \\
\text { offspring per } \\
\text { brood }\end{array}$ & units & $\mathrm{B}_{22}$ & 20 & 40 & 40 & 40 \\
\hline Mass of egg & $\mathrm{kg} /$ unit & $\mathrm{B}_{23}$ & 0.05 & 0.05 & 0.05 & 0.05 \\
\hline Mass of chicken & kg/animal & $\mathrm{B}_{24}$ & 0.9 & 0.9 & 0.9 & 0.9 \\
\hline $\begin{array}{l}\text { Number of } \\
\text { surviving } \\
\text { chicken per } \\
\text { brood }\end{array}$ & number & $\mathrm{B}_{25}$ & 9 & 10 & 10 & 10 \\
\hline $\begin{array}{l}\text { Rate of } \\
\text { offspring per } \\
\text { cow and year }\end{array}$ & Ratio & $\mathrm{B}_{26}$ & - & - & - & 0.5 \\
\hline $\begin{array}{l}\text { Average milk } \\
\text { production per } \\
\text { cow }^{5}\end{array}$ & $1 /$ cow & $\mathrm{B}_{27}$ & - & - & - & 4 \\
\hline $\begin{array}{l}\text { Number of days } \\
\text { of milk } \\
\text { production }\end{array}$ & $\mathrm{d} / \mathrm{a}$ & $\mathrm{B}_{28}$ & - & - & - & 210 \\
\hline
\end{tabular}

\footnotetext{
${ }^{4}$ Give less eggs because they are less well fed

${ }^{5}$ During the days it gives milk.
} 


$\begin{array}{lcc}\begin{array}{l}\text { Ratio auto- } \\ \text { consumption }\end{array} & \begin{array}{c}\text { Ratio milk } \\ \text { auto } \\ \text { milk }\end{array} & \begin{array}{c}\text { consumed/ } \\ \text { milk produced }\end{array}\end{array}$

Average weight piglet

$\mathrm{kg} /$ animal $\quad \mathrm{B}_{30}$

$\mathrm{kg} /$ animal $\quad \mathrm{B}_{31}$ of an adult pig

Average weight of a calf

Average weight of a cow

Average weight of a horse

Fodder consumption $\mathrm{kg} \mathrm{DM} / \mathrm{cow}^{*} \mathrm{~d} \quad \mathrm{~B}_{35}$ cows

Days of fodder consumption of cows $^{6}$

N-volatilization

factor from

manure

N-Utilization

factor of cows

$\mathrm{kg} / \mathrm{animal}$

$\mathrm{B}_{32}$

$\mathrm{kg} /$ animal $\quad \mathrm{B}_{33}$

$\mathrm{kg} /$ animal $\quad \mathrm{B}_{34}$

\section{Correction}

factor

cow/horse for

N-Losses

Share of

pasture area

burnt

Plant material

left on pasture

plots

Average manure per pig

Average

manure per

chicken/hen

Household food waste

$\mathrm{kg} /$ farm*a $\quad \mathrm{B}_{44}$

Ratio area burnt/ total pasture area

$\mathrm{B}_{40}$

0.475

0.475

$\operatorname{kg~DM/ha} \quad B_{41}$

1250

$\mathrm{kg} / \mathrm{cap}^{* a} \quad \mathrm{~B}_{42}$

0

0

55

55

$\mathrm{kg} / \mathrm{cap} * \mathrm{a} \quad \mathrm{B}_{43}$

11

11

11

${ }^{6}$ Even if insufficient food quality 
Proteins of milk

remaining in

Ratio $\quad \mathrm{B}_{45}$

0.18

whey

Firewood consumption

Ratio

off the own the own farm/

farm $^{7}$ total firewood

$\mathrm{B}_{46}$

0.34

1

consumed

Firewood

consumption/

$\mathrm{kg} / \mathrm{farm}^{*} \mathrm{a}$

$\mathrm{B}_{47}$

6800

6800

Coffee yield

$$
\mathrm{kg} / \mathrm{ha}
$$

$\mathrm{B}_{48}$

650

650

Husk

Ratio husk

production

produced/

coffee yield

$$
\mathrm{B}_{49}
$$

0.53

0.53

0.53

\section{Fertilizer}

application

coffee

$$
\mathrm{kg} / \mathrm{ha} \quad \mathrm{B}_{50}
$$

0

0

$N$ excretion per person

$$
\mathrm{kg} / \mathrm{cap}^{*} \mathrm{~d}
$$

$\mathrm{B}_{51}$

0.0075

0.01

0.01

Average rice consumption

$\mathrm{kg} /$ cap $^{*} \mathrm{~d} \quad \mathrm{~B}_{52}$

0.1

0.1

Days of rice

consumption

$$
\mathrm{d} / \mathrm{a}
$$

$\mathrm{B}_{53}$

Average sugar consumption

$\mathrm{kg} / \mathrm{cap} * \mathrm{~d} \quad \mathrm{~B}_{54}$

0.1

0.1

Days of sugar consumption

$\mathrm{d} / \mathrm{a} \quad \mathrm{B}_{55}$

365

365

Ratio maize

Maize land

used for

$$
\text { land }
$$
sharecropped/

total maize

$$
\text { land }
$$

Ratio of

Conditions of sharecropping for maize harvest given to the sharecropper

Bean land used

for

sharecropping

Ratio bean

$$
\text { land }
$$

sharecropped/

total bean land

$\mathrm{B}_{58}$

0.35

0.32

0.13

Ratio of

Conditions of sharecropping for beans harvest given to the

$\begin{array}{ll}\mathrm{B}_{59} & 0.5\end{array}$

0.5

0.5

\footnotetext{
${ }^{7}$ Based on the assumption that the farmers try to maintain the system forest in balance on their own plots.
} 


\begin{tabular}{|c|c|c|c|c|c|c|}
\hline $\begin{array}{l}\text { Workers' wage } \\
\text { in maize } \\
\text { equivalents }\end{array}$ & $\begin{array}{l}\text { Ratio workers } \\
\text { wage per day/ } \\
\text { maize price } \\
\text { per kg }\end{array}$ & $\mathrm{B}_{60}$ & - & - & 9 & 9 \\
\hline $\begin{array}{l}\text { Total of } \\
\text { working days } \\
\text { (staples) }\end{array}$ & $\mathrm{d} / \mathrm{a}$ & $\mathrm{B}_{61}$ & - & - & 170 & 337 \\
\hline $\begin{array}{l}\text { Working days } \\
\text { paid with } \\
\text { maize/ total } \\
\text { working days }\end{array}$ & Ratio & $\mathrm{B}_{62}$ & - & - & 0.5 & 0.5 \\
\hline $\begin{array}{l}\text { Workers' wage } \\
\text { in bean } \\
\text { equivalents }\end{array}$ & $\begin{array}{l}\text { Ratio workers' } \\
\text { wage for a } \\
\text { day/ bean } \\
\text { price per kg }\end{array}$ & $\mathrm{B}_{63}$ & - & - & 4.5 & 4.5 \\
\hline $\begin{array}{l}\text { Accrescence } \\
\text { coffee forest }\end{array}$ & $\mathrm{kg} / \mathrm{ha}{ }^{*} \mathrm{a}$ & $\mathrm{B}_{64}$ & - & 9300 & 9300 & 9300 \\
\hline $\begin{array}{l}\text { Accrescence } \\
\text { natural forest }\end{array}$ & $\mathrm{kg} / \mathrm{ha} a^{*} \mathrm{a}$ & $\mathrm{B}_{65}$ & - & - & 12000 & 12000 \\
\hline $\begin{array}{l}\text { Fertilizer price } \\
\text { in maize } \\
\text { equivalents }\end{array}$ & $\begin{array}{l}\text { Ratio fertilizer } \\
\text { price/ maize } \\
\text { price per kg }\end{array}$ & $\mathrm{B}_{66}$ & 1.2 & 1.2 & 1.2 & 1.2 \\
\hline
\end{tabular}




\section{Appendix D: Prices}

a) Consumer Prices

\begin{tabular}{|c|c|c|c|c|}
\hline Item & Unit & Specification & $\begin{array}{c}\text { Price in Córdobas } \\
2002\end{array}$ & Calculated with... \\
\hline Beans & pound & & $3-4$ & farmers' price \\
\hline $\begin{array}{c}\text { Cuajada } \\
\text { (Local soft cheese) }\end{array}$ & pound & season dependent & $9-13$ & 13 \\
\hline $\begin{array}{c}\text { Chicken } \\
\text { giblets/meat }\end{array}$ & pound & quality dependent & $5 / 12$ & 5 \\
\hline Clothes & $\begin{array}{l}\text { Shirt and pants/ } \\
\text { dress }\end{array}$ & quality dependent & $50-700$ & $50^{1)}$ \\
\hline Coffee & pound & in grains & $4-5$ & 4 \\
\hline Eggs & unit & & 1 & 1 \\
\hline
\end{tabular}

\section{Fertilizer}

\begin{tabular}{|c|c|c|c|c|}
\hline Urea & quintal & $45.45 \mathrm{~kg}$ & $150-160$ & 160 \\
\hline $15-15-15$ & quintal & $45.45 \mathrm{~kg}$ & 155 & - \\
\hline Fruit & unit & $\begin{array}{l}\text { depending on the } \\
\text { fruit and the season }\end{array}$ & $0.20-5$ &.$-42^{2)}$ \\
\hline Lime & pound & & -.50 &.-50 \\
\hline Maize & quintal & $45.45 \mathrm{~kg}$ & $80-200$ & 160 \\
\hline Meat & pound & quality dependent & $14-17$ & 14 \\
\hline Milk & liter & fresh & $3-5$ & 4 \\
\hline Oil & liter & unsealed/sealed & $10 / 16$ & 10 \\
\hline Rice & pound & quality dependent & $3-3.5$ & 3 \\
\hline Salt & pound & & 1 & 1 \\
\hline Shoes & pair & quality dependent & $50-700$ & 100 \\
\hline $\begin{array}{l}\text { ap (personal } \\
\text { hygiene) }\end{array}$ & unit & & 6 & 6 \\
\hline
\end{tabular}




\begin{tabular}{|c|c|c|c|c|}
\hline Soap (detergent) & unit & & $3-5$ & 3 \\
\hline Soap (dishes) & unit & & $2.5-3.5$ & 2.5 \\
\hline Shampoo & flask & $\begin{array}{c}\text { local } \\
\text { manufacturing/ } \\
\text { imported }\end{array}$ & $3.5-5 / \approx 35$ & 5 \\
\hline Soft Drink & $12 \mathrm{oz}$ & & 5 & 5 \\
\hline Sugar & pound & quality dependent & $3-4$ & 3 \\
\hline Toilet paper & Role & quality dependent & $2-3.5$ & 2 \\
\hline Vegetables & unit & $\begin{array}{l}\text { depending on the } \\
\text { vegetable and the } \\
\text { season }\end{array}$ & $0.4-7$ &.$-42^{3)}$ \\
\hline
\end{tabular}

\section{b) Farmers' prices}

\begin{tabular}{|c|c|c|c|c|}
\hline Item & Unit & Specification & $\begin{array}{c}\text { Price in Córdobas } \\
2001 / 02\end{array}$ & Calculated with... \\
\hline Beans & quintal & $45.45 \mathrm{~kg}$ & $200-250^{1)}$ & 250 \\
\hline Coffee & quintal & $45.45 \mathrm{~kg}$ & & 250 \\
\hline $\begin{array}{c}\text { Cuajada (local } \\
\text { cheese) }\end{array}$ & pound & season dependent & $9-13$ & 13 \\
\hline Maize & quintal & $45.45 \mathrm{~kg}$ & $70-200$ & 120 \\
\hline Milk & 1 & farmers sells & 3 & 3 \\
\hline $\begin{array}{c}\text { Wage of agricultural } \\
\text { worker }\end{array}$ & per day & & & \\
\hline Male & & & $20-25$ & 25 \\
\hline Female & & & $15-20$ & 2) \\
\hline
\end{tabular}




\begin{tabular}{|c|c|c|c|c|}
\hline Animals & Unit & Specification & $\begin{array}{c}\text { Price in Córdobas } \\
2001 / 02\end{array}$ & Calculated with... \\
\hline Calf & live animal & & $1500-2000$ & 2000 \\
\hline Cow & live animal & Not fertile yet & 3500 & 3500 \\
\hline Milk cow & live animal & Fertile & $6000-8000$ & 7500 \\
\hline Pig & live animal & depends on the race & $600-1000$ & 800 \\
\hline Piglet & live animal & about 2 months old & 150 & 150 \\
\hline
\end{tabular}




\section{Appendix E: The concept of the Canasta básica - basic needs}

\section{a) Concept of the Canasta básica}

In Nicaragua, the Canasta básica, or basic basket, is an official term for a list of 53 items a family needs every month to maintain a minimal standard of living. Yet, as rural needs differ slightly from the urban ones, in this study an own canasta básica has been defined based on information about needs gathered in the field. These have been complemented with some articles like vegetables and fruit which are crucial for a balanced diet. It also includes a small "luxury" which is a soft drink once a month for each family member. It could also be replaced by a beer, cookies or other items. Nevertheless, it has to be emphasized that the canasta básica, like stated by its name, corresponds to basic needs and is by no means an indicator for decent living. Firstly, each family member gets only one new outfit of bad quality per year. Illnesses are restricted to non-serious cases and education to primary school. No traveling has been included, although many farmers need to travel to the close by cities. Last but not least it has to be borne in mind that the costs of the canasta básica merely amount to -.62 US\$ per person and day.

The minimum needs have been reduced to the items needed for survival. Education has been included because of its uttermost importance in the development of a human being.

\section{b) The Canasta Básica for a family of six}

\begin{tabular}{|c|c|c|}
\hline Articles & Amount & Prices per Month $[C \$]^{1}$ per family \\
\hline Maize & $300 \mathrm{~g} / \mathrm{cap}^{*} \mathrm{~d}$ & 194 \\
\hline Beans & $200 \mathrm{~g} / \mathrm{cap}^{*} \mathrm{~d}$ & 200 \\
\hline Sugar & $100 \mathrm{~g} / \mathrm{cap}^{*} \mathrm{~d}$ & 120 \\
\hline Rice & $100 \mathrm{~g} /$ cap $^{*} \mathrm{~d}$ & 120 \\
\hline Coffee & $1 \mathrm{Bag} / \mathrm{d}(1 \mathrm{oz})$ & 8 \\
\hline Salt & $1 \mathrm{Bag} / \mathrm{month}(1 \mathrm{lb})$ & 1 \\
\hline Lime & 2 Bags/month (2lb) & 1 \\
\hline Oil & 1 flask/month (11) & 10 \\
\hline Cheese & $2 \mathrm{lb} /$ week & $72-104$ \\
\hline Meat & $1 \mathrm{lb} /$ week & 56 \\
\hline Chicken & $1 \mathrm{lb} /$ week & $20-48$ \\
\hline Eggs & 2 units/cap*week & 48 \\
\hline Pop & 1 per cap and week & 120 \\
\hline Fruit & 2 port. per cap and day & 150 \\
\hline Vegetables & 2 port. per cap and day & 150 \\
\hline
\end{tabular}

\footnotetext{
${ }^{1}$ In 2001 the Nicaraguan Córdoba Oro was at about 14 per US\$.
} 
Onion/Garlic/Chiltoma ${ }^{2}$

Soap (personal hygiene)

Soap (detergent)

Soap (dishes)

Toilet paper

Shampoo

$\begin{array}{cc}1 \text { per month } & 6 \\ 1 \text { per 2 weeks } & 6 \\ 1 \text { per month } & 2 \\ 1 \text { per week } & 2 \\ 1 \text { per month } & 5\end{array}$

6

6

2

2

5
20

Assumption monthly average of C\$ per family:

Expenditures per year for food and hygiene:

C\$ per family and year

16080

\section{Clothes}

Shoes

Clothes

Illness

School fees

Graduation and other additional

school fees

\section{Amount}

1 pair/cap*a

1 per/cap*a
1000

400

500

C\$ per family and year

Total expenditures per year for schooling, health and clothes

c) The Canasta mínima - the minimum Needs - for a family of six

\section{Minimum}

Maize

Beans

Sugar

Rice

Coffee

Salt

Lime

Oil

\section{Amount}

$$
300 \mathrm{~g} / \mathrm{cap}^{*} \mathrm{~d}
$$$$
200 \mathrm{~g} / \mathrm{cap}^{*} \mathrm{~d}
$$$$
100 \mathrm{~g} / \text { cap }^{*} \mathrm{~d}
$$$$
100 \mathrm{~g} / \text { cap }^{*} \mathrm{~d}
$$$$
1 \mathrm{Bag} / \mathrm{d}(1 \mathrm{oz})
$$

$1 \mathrm{Bag} /$ month (1lb)

2 Bags/month (2lb)

1 flask/month (11)
Prices per Month $[\mathrm{C} \$]^{3}$ per family

194

200

8

1

1

10

\footnotetext{
${ }^{2}$ Nicaraguan Pepper

${ }^{3}$ In 2001 the Nicaraguan Córdoba Oro was at about 14 per US\$.
} 


$\begin{array}{ccr}\text { Soap (pers.) } & 1 \text { per month } & 6 \\ \text { Soap (clothes) } & 1 \text { per 2 weeks } & 6 \\ \text { Toilet paper } & 1 \text { per week } & 2\end{array}$

Assumption monthly average of C\$ per family::

Expenditures per year for food and hygiene:

Clothes

Shoes

Clothes

Illness

School fees

Graduation school and other additional fees

Total expenditures per year for schooling, health and clothes
C\$ per family and year

8016

Amount

1 pair/cap*a

1 per/cap*a

300

1000

400

500

C\$ per family and year

2800

Total expenditures per year

CS per family and year

8816

\section{d) Further asssumptions}

Furthermore, in the calculation of the canasta básica coverage all the expenses for workforce were subtracted. Coffee was not fertilized and pasture not burnt. It was assumed that the medium farmer sells his pig and the big farmer sells one and consumes the other. Also, the latter sells each year a (male) calf (C\$ 2000) and alternately either a heifer (C\$ 3500) or a cow (C\$ 6000-8000).

\section{e) Sources}

Items: The items needed by a rural family were aggregated based on interviews, observations and assumptions.

Amount: The amount of the items per capita and day have been estimated based on interviews, observations and assumptions.

Price: The price information has been gathered in a grocery store in the town of San Dionisio. 


\section{APPENDIX F: DYNAMIC MODEL}

\section{Description of the model}

The dynamic model developed for this study describes the metabolism of natural renewable resources, which are used according to different strategies. After the variables, a description of the modules' setup is given for the example of maize. For the other modules only diverging elements are listed.

\section{VARIABLES}

\section{$\underline{\text { 1. Module Maize }}$}

$M_{1}(t)$ : Maize stock on the fields

$M_{2}(t)$ : Maize storage stock

$\dot{M}_{1}(t)$ : Derivation Maize stock on the fields

$\dot{M}_{2}(t)$ : Derivation Maize storage stock

$Q_{M_{1}}(t)$ : Growth term Maize

$m_{1}(t)$ : Maize harvest

$m_{2}(t)$ : Maize consumption

$m_{3}(t)$ :Fodder (maize)

$m_{4}(t)$ : Maize sale

$m_{5}(t)$ :Maize seeds

$m_{6}(t)$ : Chemical fertilizer for maize

$m_{7}(t)$ : Import maize seeds

$m_{8}(t)$ : Labor input maize

\section{Module Beans}

$B_{1}(t)$ : Bean stock on the fields

$B_{2}(t)$ : Bean storage stock

$\dot{B}_{1}(t)$ : Derivation Bean stock on the fields

$\dot{B}_{2}(t)$ : Derivation Bean storage stock

$Q_{B_{1}}(t)$ : Growth term Beans

$b_{1}(t)$ : Bean harvest

$b_{2}(t)$ : Bean consumption

$b_{3}(t)$ : Bean sale

$b_{4}(t):$ Bean seeds

$b_{5}(t)$ : Chemical fertilizer for beans

$b_{6}(t)$ : Import bean seeds

$b_{7}(t):$ Labor input 


\section{$\underline{3 .}$ Module Forest}

$W_{1}(t)$ : Forest stock

$\dot{W}_{1}(t)$ : Derivation forest stock

$Q_{W_{1}}(t)$ : Growth term forest

$w_{1}(t):$ Firewood

\section{Module Coffee}

$K_{1}(t)$ : Coffee stock on the field

$K_{2}(t)$ :Coffee storage stock

$\dot{K}_{1}(t)$ : Derivation coffee stock on the field

$\dot{K}_{2}(t)$ :Derivation coffee storage stock

$Q_{K_{1}}(t)$ : Growth term coffee

$k_{1}(t)$ : Exportation of coffee

$k_{2}(t)$ : Consumption of coffee

$k_{3}(t)$ : Chemical fertilizer for coffee

$k_{4}(t)$ : Labor input coffee

\section{Module animals/animal population}

$T_{1}(t)$ : Chicken population

$T_{2}(t)$ : Pig population

$T_{3}(t)$ : Cow population

$T_{4}(t)$ : Horse and mule population

$T_{5}(t)$ :Pasture stock

$\dot{T}_{1}(t)$ :Derivation chicken population

$Q_{T_{1}}(t)$ : Growth term chicken population

$\dot{T}_{2}(t)$ : Derivation pig population

$Q_{T_{2}}(t)$ : Growth term pig population

$\dot{T}_{3}(t)$ : Derivation cow population

$Q_{T_{3}}(t)$ : Growth term cow population

$\dot{T}_{4}(t)$ : Derivation horse and mule population

$Q_{T_{4}}(t)$ : Growth term horse and mule

$\dot{T}_{5}(t)$ :Derivation pasture stock

$Q_{T_{5}}(t)$ : Growth term pasture stock

$t_{1}(t)$ : Egg consumption and production

$t_{2}(t)$ : Consumption of chicken

$t_{3}(t)$ : Exportation of chicken

$t_{4}(t)$ : Pigs' meat consumption

$t_{5}(t)$ : Export of pig meat 
$t_{6}(t)$ : Consumption of milk

$t_{7}(t)$ : Beef consumption

$t_{8}(t)$ : Cow exportation

$t_{9}(t)$ : Exportation of mules and horses

$t_{10}(t)$ : Importation of chicken

$t_{11}(t)$ : Importation of pigs

$t_{12}(t)$ : Importation of cows

$t_{13}(t)$ : Importation of horses and mules

$t_{14}(t)$ : Consumption of pasture

$t_{15}(t)$ : Labor force animals

$t_{16}(t)$ : Labor input pasture

\section{Module Household}

$h_{1}(t)$ :Importation of sugar

$h_{2}(t)$ : Importation of rice

\section{SYSTEM EQUATIONS}

\section{$\underline{\text { 1. Module Maize }}$}

$$
\begin{aligned}
& F_{1}=M_{1}(t)-M_{1}(0)-\int_{0}^{t} \dot{M}_{1}\left(t^{\prime}\right) d t^{\prime}=0 \\
& F_{2}=M_{2}(t)-M_{2}(0)-\int_{0}^{t} \dot{M}_{2}\left(t^{\prime}\right) d t^{\prime}=0
\end{aligned}
$$

Balance Equations

$$
\begin{aligned}
& F_{1}=\dot{M}_{1}(t)+m_{1}(t)-Q_{M_{1}}(t)=0 \\
& F_{2}=\dot{M}_{2}(t)-m_{1}(t)+m_{2}(t)+m_{3}(t)+m_{4}(t)+m_{5}(t)=0 \text { as long as } M_{2}(t) \geq 0 \text { else } \dot{M}_{2}(t)=0
\end{aligned}
$$

\section{Model Approach}

logistic growth approach for maize

$F_{3}=Q_{M_{1}}(t)-f_{\dot{M}_{i}}\left(P_{F_{1}}, P_{1}, M_{1}\right)=0$

$f_{\dot{M}_{1}}$ : Growth function for maize

e.g. $f_{\dot{M}_{1}}=P_{F_{1}}\left(P_{1,1}+P_{1,2} \frac{M_{1}(t)}{P_{F_{1}}(t)}+P\left(\frac{\left(M_{1}(t)\right.}{P_{F_{1}}(t)}\right)^{2}\right)$ log. growth function

$P_{F_{1}}(t)$ : Area of maize production

$P_{1,1} \ldots P_{1,3}:$ Parameters for growth function of maize

Maize harvest

$F_{6}=m_{1}+f_{m_{1}}\left(M_{1}, t\right)=0$

$f_{m_{1}}:$ Harvest function 
Maize consumption

$F_{7}=m_{2}-f_{m_{2}}\left(P_{0}, M_{2}, P_{2}\right)=0$ while $M_{2}(t) \geq 0$ else $F_{7}=m_{2}=0$

$P_{0}$ : Population

$P_{2}$ :Parameters for maize consumption

Fodder maize

$F_{8}=m_{3}-f_{m_{3}}\left(T_{1}, M_{2}, P_{3}\right)=0$ while $M_{2}(t) \geq 0$ else $F_{8}=m_{3}=0$

$T_{1}$ : Animal population $\mathrm{T}_{1}$

$P_{3}$ : Parameters for fodder maize consumption

Sale Maize

$F_{9}=m_{4}-f_{m_{4}}\left(M_{2}, P_{0}, T_{1}, P_{4}\right)=0$ while $M_{2}(t) \geq 0$ else $F_{9}=m_{4}=0$

$P_{4}$ : Parameters for sale of maize

Sale strategy: Sell every two weeks a minimum

share in order to purchase salt, lime etc.

Maize seeds

$F_{10}=m_{5}-f_{m_{5}}\left(P_{F_{1}}, P_{5}\right)=0$

$f_{m_{5}}$ :Maize seeds e.g. $21 \mathrm{~kg} /$ ha per year

Chemical fertilizer maize

$F_{11}=m_{6}-f_{m_{6}}\left(P_{F_{1}}, P_{6}, \ldots\right)=0$

$f_{m_{6}}$ :Chemical fertilizer e.g. y kg/a

$P_{6}: \mathrm{y} \mathrm{kg}$

Import seeds

$F_{12}=m_{7}-f_{m_{7}}\left(P_{F_{1}}, P_{7}, m_{5}, \ldots\right)=0$

$f_{m_{7}}$ :Seed import e.g. $1 / 3$ of the total seed

$P_{7}:$ Share of the imported seed

Workforce maize

$F_{13}=m_{8}-f_{m_{8}}\left(P_{F_{1}}, P_{8}, \ldots\right)=0$

$f_{m_{8}}$ : needed labor input/ha

$P_{8}:$ Technology factor

\section{LOGISTIC GROWTH FUNCTION WITH A CONSTANT TERM}

Differential Equation:

$\dot{M}=P_{0}+P_{1} M-P_{2} M^{2}$

$M(0)=0$ 
Solution: Logistic growth function and growth term as a function of $t$

$M(t)=\frac{2 P_{0}}{P_{1}+\chi}\left[\frac{2 \chi}{\chi-P_{1}} \frac{1}{1+e^{-\chi(t-\tau)}}-1\right]$

where

$\chi:=\sqrt{4 P_{0} P_{2}+P_{1}^{2}}$

$e^{\chi \tau}=\frac{\chi+P_{1}}{\chi-P_{1}}$ 


\title{
CURRICULUM VITAE
}

\author{
PFISTER, Franziska Rita \\ Geboren am 19. August 1973 \\ Bürgerin von Uetendorf BE
}

1999-2003 Doktorat der Wissenschaften und Lehrassistenz an der Professur für Stoffhaushalt und Entsorgungstechnik, ETH Zürich

2000-2002

Nachdiplomkurs für Entwicklungsländer (NADEL) an der ETH Zürich

1998-1999 Projektmitarbeiterin an der Universität für Agrarwissenschaften (Universidad Nacional Agraria) in Managua und bei der lokalen Nichtregierungsorganisation ODESAR in Matagalpa, Nicaragua 1993-1998 Biologiestudium an der ETH Zürich

1996 Freiwilligeneinsatz in einer landwirtschaftlichen Kooperative, Jinotepe, Nicaragua

1993 Freiwilligeneinsatz in einer Kinderkrippe, Masatepe, Nicaragua 1988-1993 Wirtschaftsgymnasium Neufeld 1980-1988 Obligatorische Schulen in Jegenstorf und Bern 